\title{
Soil quality and ecosystem services of peat grasslands
}
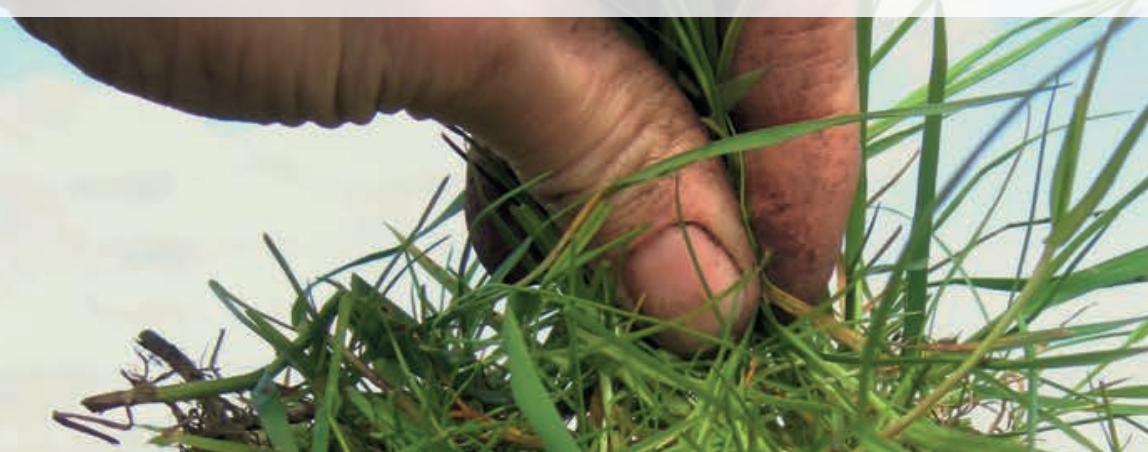



\section{Propositions}

1. Whether dairy grassland is more or less biodiverse than semi-natural grassland depends on the scale of observation.

(this thesis)

2. Earthworms in peat soil benefit from adding fresh organic matter. (this thesis)

3. Diversity in management between and within farms is a driver of biodiversity at the landscape scale.

4. A scientific mind is needed in practice and a practical mind is needed in science.

5. Philosophiæ Doctores are required in life sciences to understand 'life'.

6. The generalist species Homo sapiens would profit more from investing in general body resilience and ecosystem stability than in specific immunity against ever mutating viruses.

7. For a PhD candidate, the advantage of having growing children is that obstacles are put in perspective.

Propositions belonging to the thesis, entitled

Soil quality and ecosystem services of peat grasslands

Joachim G.C. Deru

Wageningen, 15 September 2021 



\section{Soil quality and ecosystem services of peat grasslands}

Joachim Deru 


\section{Thesis committee}

\section{Promotor}

Prof. Dr L. Brussaard

Professor of Soil Biology and Biological Soil Quality

Wageningen University \& Research

\section{Co-promotors}

Dr N.J.M. van Eekeren

Senior Researcher and Programme Coordinator Sustainable Animal Production and Agrobiodiversity

Louis Bolk Institute, Bunnik

Dr R.G.M. de Goede

Assistant Professor, Soil Biology Group

Wageningen University \& Research

Dr J. Bloem

Senior Scientist, Animal Ecology

Wageningen University \& Research

\section{Other members}

Prof. Dr F.K.D. Taube, Wageningen University \& Research

Prof. Dr F.T. de Vries, University of Amsterdam

Dr M.M. Hefting, Utrecht University

Prof. Dr J.W. Erisman, Leiden University

This research was conducted under the auspices of the C.T. de Wit Graduate School for Production Ecology \& Resource Conservation (PE\&RC) 


\title{
Soil quality and ecosystem services of peat grasslands
}

\author{
Joachim Deru
}

\section{Thesis}

submitted in fulfilment of the requirements for the degree of doctor at Wageningen University by the authority of the Rector Magnificus,

Prof. Dr A.P.J. Mol, in the presence of the

Thesis Committee appointed by the Academic Board to be defended in public

on Wednesday 15 September 2021 at 11 a.m. in the Aula. 
Joachim G.C. Deru

Soil quality and ecosystem services of peat grasslands, 188 pages

PhD thesis, Wageningen University, Wageningen, the Netherlands (2021) With references, with summary in English and Dutch

ISBN: 978-94-6395-842-4

DOI: https://doi.org/10.18174/548000 


\section{Table of contents}

Summary

Chapter 1 General introduction

Chapter 2 Soil ecology and ecosystem services of dairy and semi-natural grasslands on peat

Chapter 3 Predicting soil N supply and yield parameters in peat grasslands

Chapter 4 Effects of $\mathrm{Ca}: \mathrm{Mg}$ ratio and $\mathrm{pH}$ on soil chemical, physical and microbiological properties and grass $\mathrm{N}$ yield in drained peat soil

Chapter 5 Effects of organic and inorganic fertilizers on soil properties related to the regeneration of ecosystem services in peat grasslands

Chapter 6 General discussion

References

Samenvatting

179

Dankwoord

182

About the author

185

List of publications

186

PE\&RC Training and Education Statement

187

Funding 


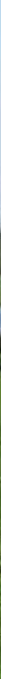

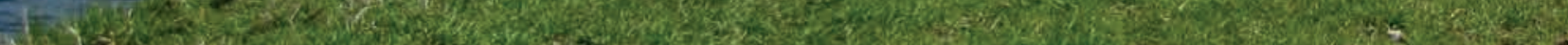

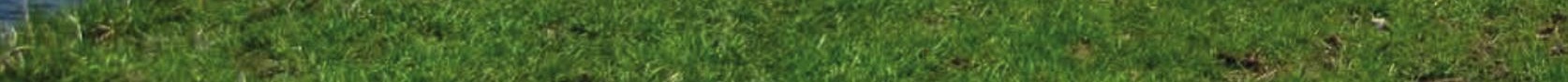

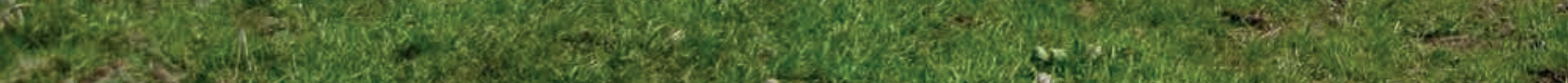

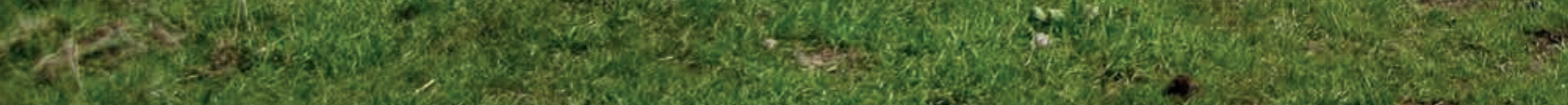
W.

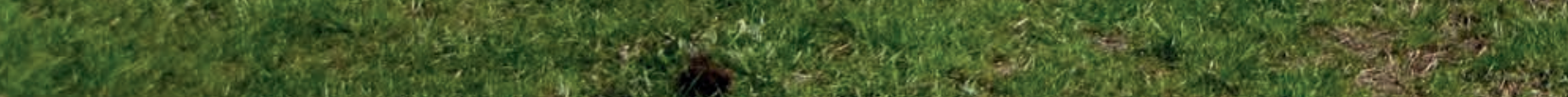

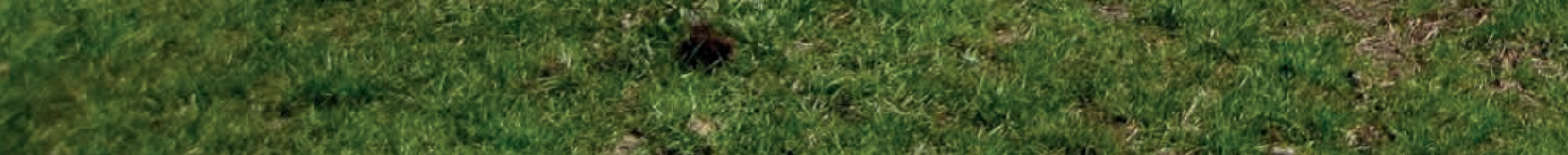

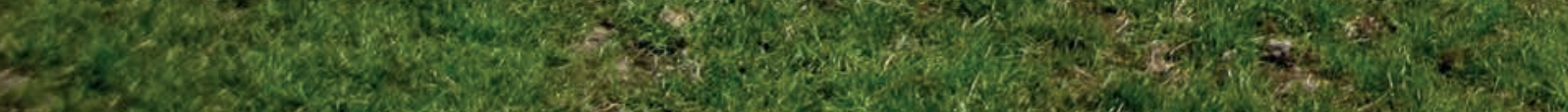

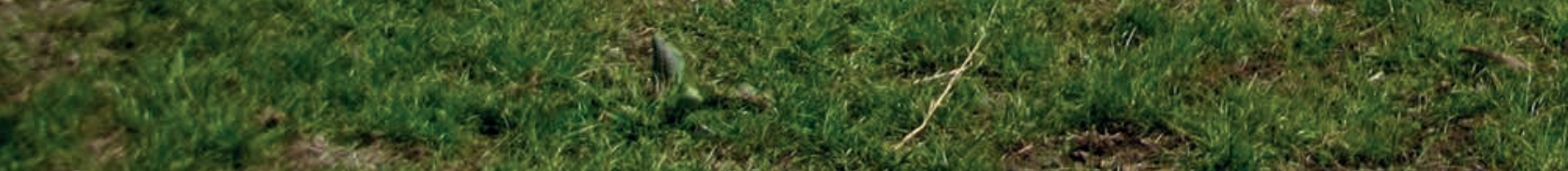

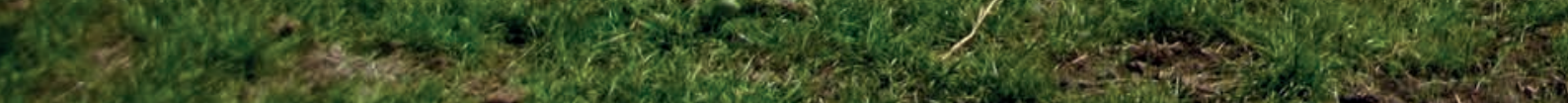




\section{Summary}
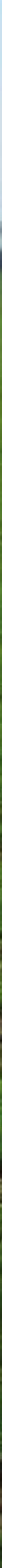



\section{Summary}

Worldwide, drained peat covers only $0.3 \%$ of the land area but net decomposition of the organic matter under aerobic conditions contributes $6 \%$ to anthropogenic $\mathrm{CO}_{2}$ emissions. With current climate change, governments globally are therefore urged to reduce $\mathrm{CO}_{2}$ emission in those areas. For drained peat grasslands in the Netherlands, society requires from farmers and other land owners not only that peat decomposition is reduced, but also that key elements of biodiversity such as meadow birds are protected and supported, that soils can buffer extreme weather events such as droughts and floods, and that nutrient losses are minimized. Thus, agriculture is no longer required to deliver provisioning services (food production) only, but increasingly also supporting and regulating ecosystem services. This mix of demands calls for an integral approach when evaluating possible management measures.

The overall aim of this thesis is to get insight in soil quality of peat grasslands in relation to the ecosystem services support of biodiversity, climate regulation, water regulation and grass production, and to evaluate the effects of land use and land management from this integral perspective. To this end, I carried out soil and vegetation measurements in experiments in dairy and semi-natural grasslands across the western peat region of the Netherlands.

The effects of land use on the delivery of ecosystem services were assessed by comparing twenty dairy and twenty semi-natural grasslands, differing in drainage depth, grazing, mowing and fertilization intensity. Chapter 2 presents botanical parameters and a comprehensive set of biotic and abiotic parameters from the topsoil of these grasslands. The dairy grasslands had a drier, nutrient richer and more productive soil, a more abundant soil fauna and higher water infiltration capacity than the semi-natural grasslands. The semi-natural grasslands were lower in floral and soil $\alpha$-diversity, but higher in $\mathrm{\gamma}$-diversity. This could be explained from differences in resource availability and spatial heterogeneity between the land uses. Potential $\mathrm{C}$ mineralization rates were similar in dairy and semi-natural grasslands. However, C mineralization was based on a bacterial decomposition pathway and was limited by drought in the dairy grasslands, whereas it was based on a more fungal decomposition pathway in the semi-natural grasslands. I conclude this chapter with recommendations for land management of dairy and semi- 
natural grasslands in relation to the ecosystem services biodiversity, climate regulation, water regulation and grass production.

In Chapter 3, I focus on the ecosystem service grass production in relation to $\mathrm{N}$ mineralization in soil. Due to large variation in unfertilized grass $\mathrm{N}$ yield (a proxy for soil $\mathrm{N}$ supply) across dairy grasslands on peat, the current fertilization guideline based on a fixed soil $\mathrm{N}$ supply may induce unnecessary large $\mathrm{N}$ losses. The aim of this chapter is to develop a prediction tool for soil $\mathrm{N}$ supply of dairy grasslands on peat and ultimately help reduce losses. I used the data of Chapter 2, extended them with three different estimations of soil $\mathrm{N}$ mineralization during the growing season (1: based on laboratory incubation; 2: based on production ecological calculations; 3: based on a combination of both), and correlated those with the grass yield measured in the same twenty dairy grasslands during that year. No match was found between the variation in soil $\mathrm{N}$ supply and that in soil $\mathrm{N}$ mineralization as estimated with the soil ecological data. However, the soil parameters Ca:Mg ratio and C to soil organic matter (C:SOM) ratio were statistically the best predictors of soil $\mathrm{N}$ supply and fertilized grass yield, respectively. Ca:Mg ratio and C:SOM ratio were related to soil structure and water availability. I conclude that part of the spatial variation in grass yield was predicted with indicators of soil physical-hydrological properties, without direct link with $\mathrm{N}$ mineralization.

Based on the results of Chapter 3, I hypothesized that increasing the soil Ca:Mg ratio would increase grass growth due to positive effects on soil structure or water availability, which could potentially reduce $\mathrm{N}$ losses. In Chapter 4 , I present the results of a factorial experiment on three peat grasslands differing in initial soil $\mathrm{Ca}: \mathrm{Mg}$ ratio. Here, the soil $\mathrm{Ca}: \mathrm{Mg}$ ratio was changed by adding two minerals that influenced $\mathrm{pH}\left(\mathrm{CaCO}_{3}\right.$ and $\left.\mathrm{MgCO}_{3}\right)$ and two $\left(\mathrm{CaSO}_{4}\right.$ and $\left.\mathrm{MgSO}_{4}\right)$ that did not. Within the two years of the experiment, the unfertilized grass $\mathrm{N}$ yield was influenced by changes in soil $\mathrm{pH}$ and organic matter mineralization mainly in the first year, but not by the Ca:Mg ratio. The addition of lime $\left(\mathrm{CaCO}_{3}\right)$ increased the soil $\mathrm{pH}$ and reduced total $\mathrm{N}$ and $\mathrm{C}$, indicating significant soil $\mathrm{N}$ and $\mathrm{C}$ mineralization. From the different treatment effects on $\mathrm{pH}, \mathrm{SOM}$ and hot waterextractable C (HWC, a labile C pool), I deduced that the $\mathrm{pH}$-related SOM decomposition depends also on $\mathrm{P}$ availability and $\mathrm{Ca}$ binding. Therefore, I conclude that manipulating the soil Ca:Mg ratio does not influence grass $\mathrm{N}$ uptake, at least not in the first two years after application of the minerals. Moreover, to avoid soil losses of $\mathrm{C}$ and $\mathrm{N}$, the current 
agricultural advice of $\mathrm{pH}$ management in peat grasslands should be adapted to local soil properties.

In another field experiment, the application of organic and inorganic fertilizers during three consecutive growing seasons was evaluated as a measure to combine ecosystem services of peat grasslands, with emphasis on support of biodiversity (Chapter 5). Fertilizers were applied at a fixed, moderate amount of total $\mathrm{N}\left(120 \mathrm{~kg} \mathrm{ha}^{-1} \mathrm{yr}^{-1}\right)$ that resulted in different amounts of total $C$ applied per treatment due to differences in fertilizer C:N ratios. I found an increase in detritivorous (epigeic) earthworms in plots to which the solid fraction of slurry manure had been added, which was the fertilizer with the highest $\mathrm{C}: \mathrm{N}$ ratio and largest input of organic matter. A similar effect was observed where sawdust was combined with $\mathrm{N}$ fertilizer. Compared to the fertilizers with lower $\mathrm{C}: \mathrm{N}$ ratios, those treatments also promoted arbuscular mycorrhizal fungi, which possibly explains the lack of negative effects on grass yield. I conclude that the use of organic fertilizers with high and non-humified organic matter content can be part of a regeneration strategy of ecosystem services in peat grasslands.

This thesis provides an integral insight on the delivery of ecosystem services in peat grasslands, and explores ways to use and manage peat soils to address demands of society. In Chapter 6, the results of the previous chapters are discussed and synthesized from the perspective of the ecosystem services support of biodiversity, climate regulation, water regulation and grass production. I conclude that soil biotic and abiotic quality forms the basis of vital ecosystem services delivered by peat grasslands, and that managing those ecosystem services is inextricably related to influencing the dynamics of soil organic matter and soil hydrology. To better face the challenges of agriculture on peatland in the coming decades, a fertile cooperation of dairy farmers with nature conservation organizations and the society as a whole will be needed. 


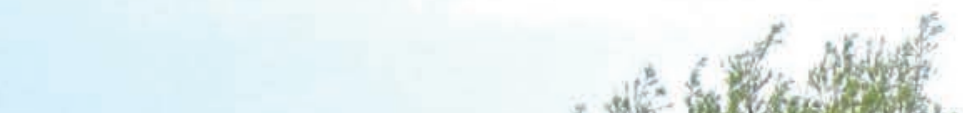

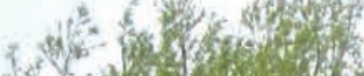

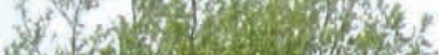

How

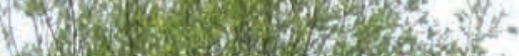

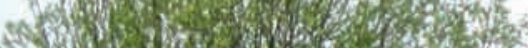

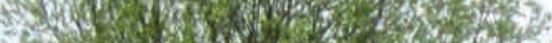

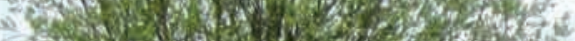

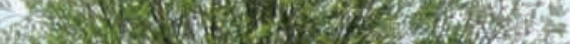

4.

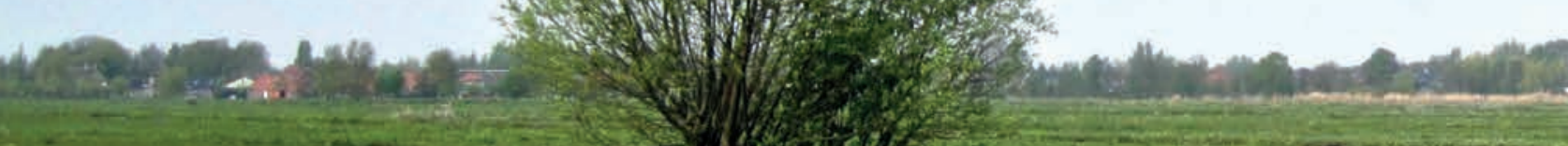

-

\section{nescon}

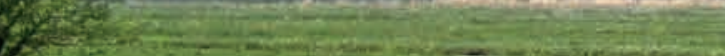

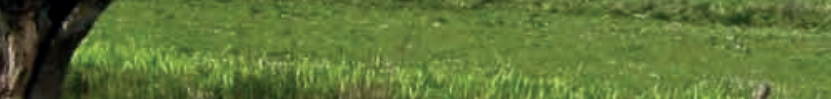

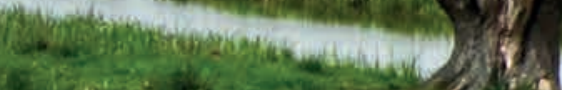

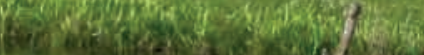

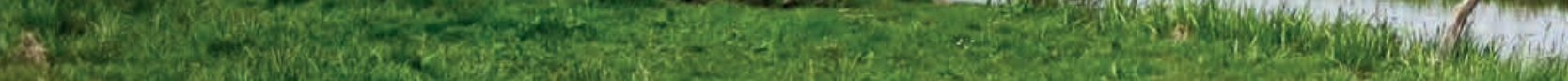

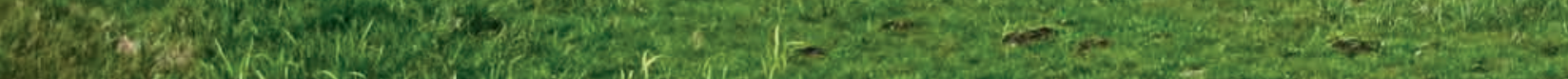

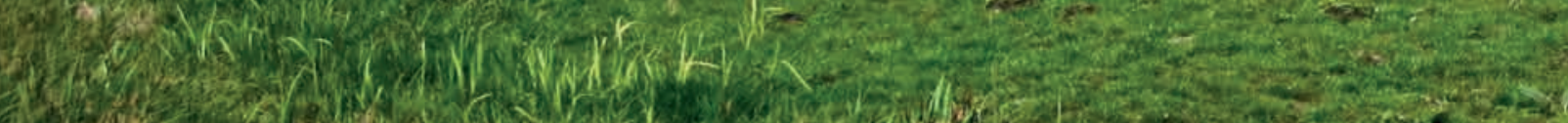

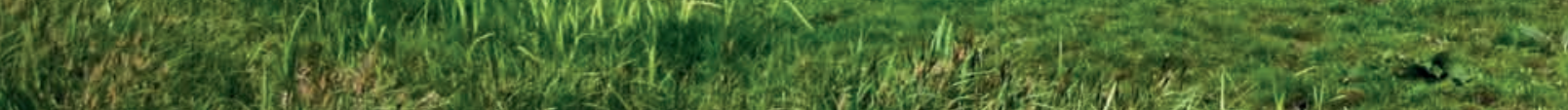

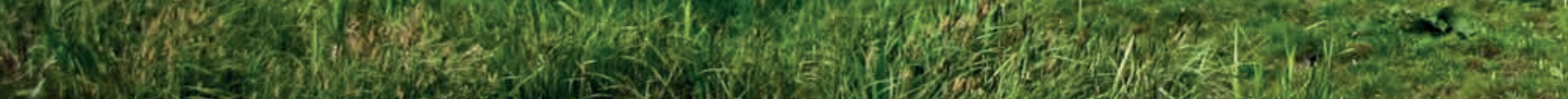

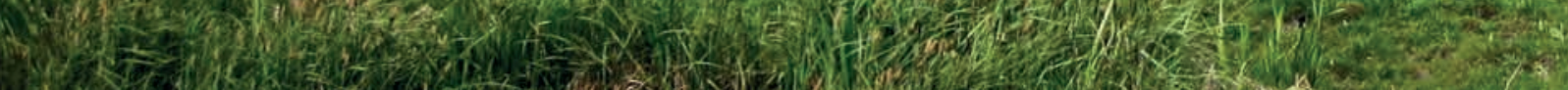
A

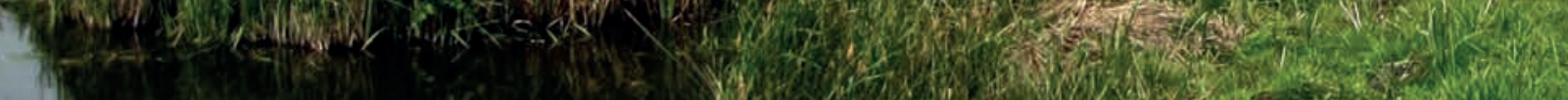

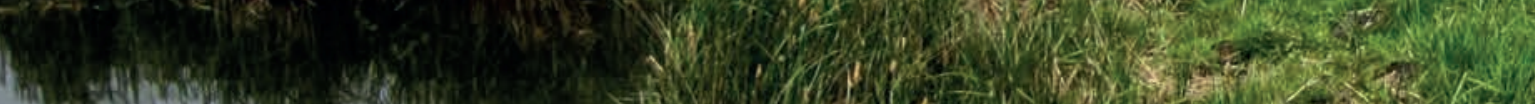

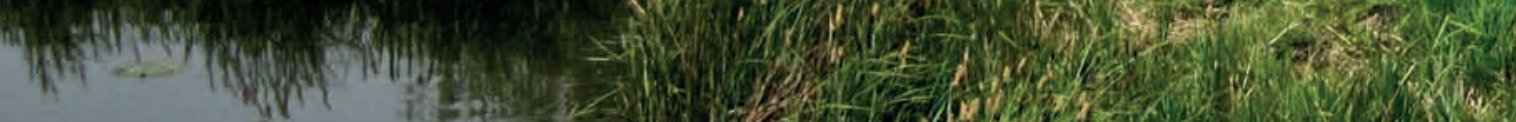




\section{Chapter 1}

\section{General introduction}

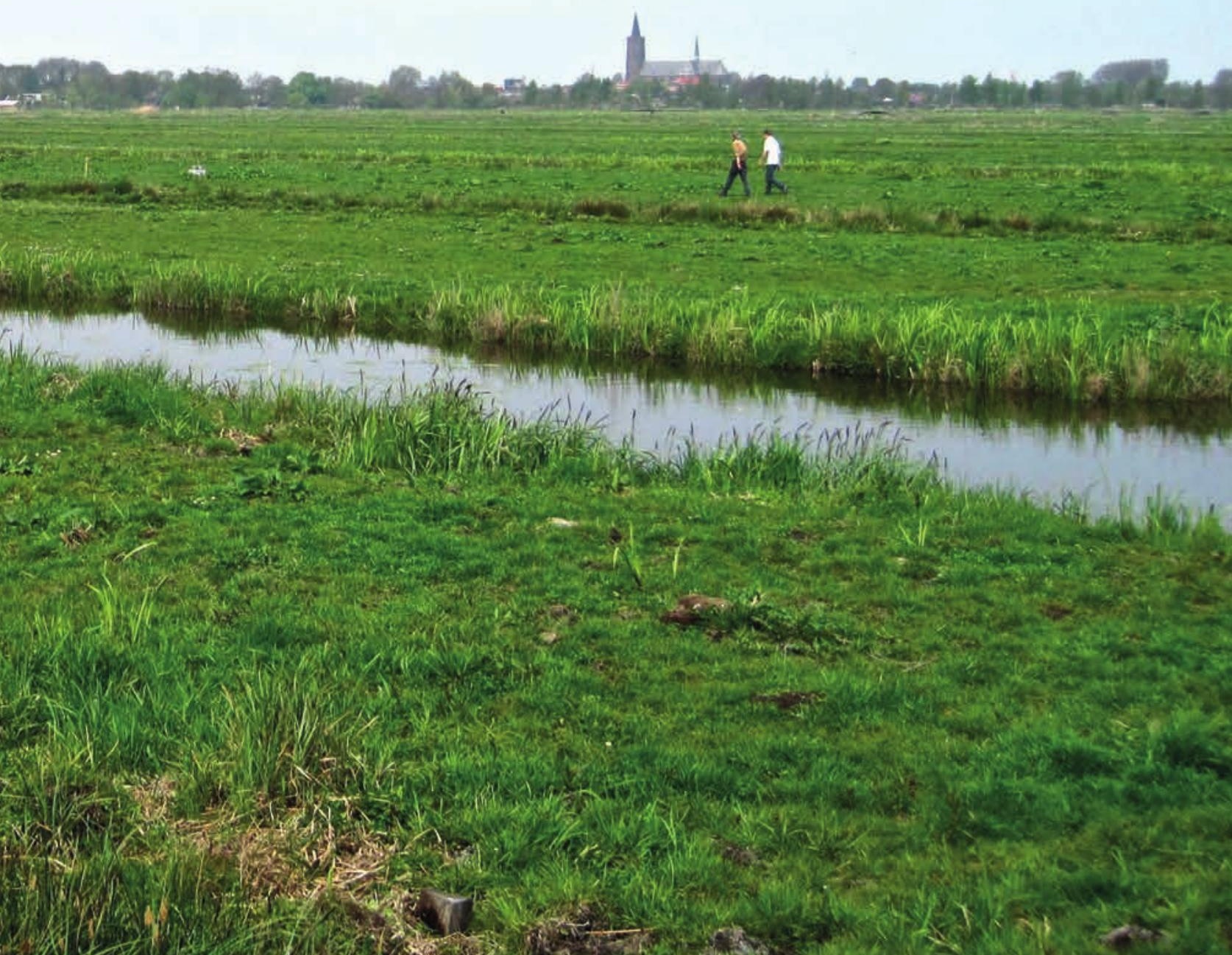





\subsection{Peat soils}

In areas covered by growing plants where the soil conditions are wet and acidic, decomposition of plant residues may be slower than their production. This results in net accumulation of organic matter and in the formation of a peat layer on top of a mineral soil. Globally, $3 \%$ of the land surface is covered by peat that contains one third of the soil organic carbon pool (Parish et al., 2008). In wetlands in temperate and boreal regions of the northern hemisphere, large peat areas have been formed during the past 15,000 years where decomposition was also limited by the cold climate. In the Netherlands, most peat soils contain mineral deposits like clay that originate from sea and river floods and can be found as layers or mixed in the organic matter. Peat soils are defined as having more than $40 \mathrm{~cm}$ peaty material within the top $80 \mathrm{~cm}$ soil layer. Peaty material has at least 15 (at a clay content of $0 \%$ ) to 23 (at a clay content of 50\%) mass percentage of organic matter (De Bakker and Locher, 1991).

Natural peat ecosystems are not only carbon sinks, but also reservoirs of specific biodiversity, flood protectors and water quality regulators (Maltby and Immirzi, 1993; Verhoeven and Setter, 2010).

\subsubsection{Drained peatland}

Worldwide, approximately $10 \%$ of the peat area is artificially drained for economic purposes, mainly agriculture or silviculture. Compared to the rest of the world, drainage and agricultural use of peatlands in the Netherlands is intensive, and has a long history (Ritzema and Stuyt, 2015; Van de Ven, 1993). Agriculture on peatland became possible from the Middle Ages onwards, after large-scale land reclamation with parcelling, drainage and lowering of the water table, made possible by a dense network of ditches and canals. This created an aerobic topsoil suitable for crops and grassland, with increased load bearing capacity for animals, machinery, roads and buildings. Over the centuries, farmers further improved the agricultural value of drained peat soil by applying toemaak to the surface, a mixture of composted organic manure, crop residues, ditch sludge and city waste (Sonneveld and Lantinga, 2011).

In the Middle Ages, c. $50 \%$ of area of the Netherlands was covered by peat, but this percentage diminished progressively due to peat harvesting for fuel and peat 


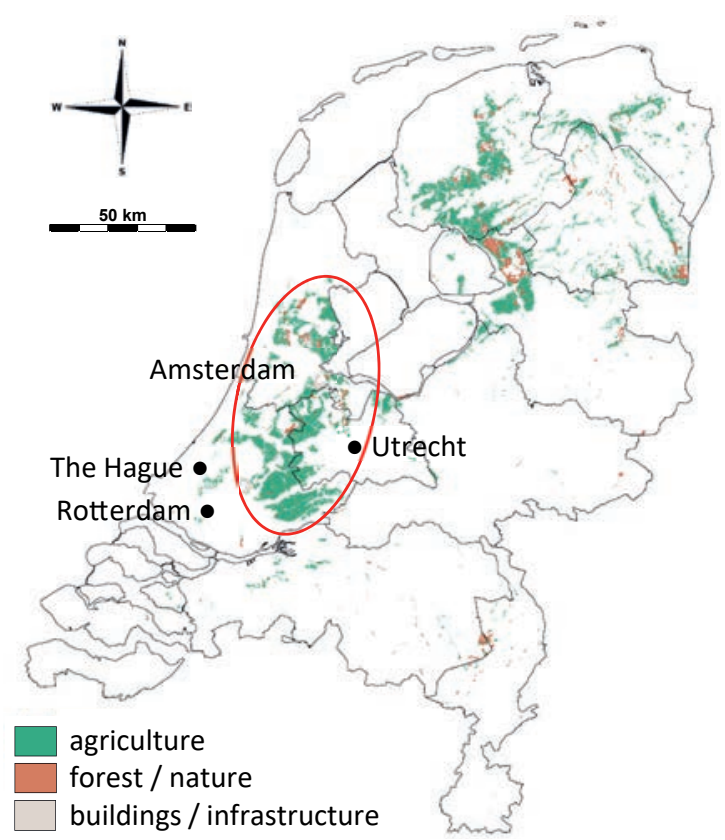

Figure 1.1 Land use of peat areas in the Netherlands (Van Kekem, 2004) with the study area of this thesis (ellipse: western peat district).

decomposition in the drained topsoil (Van de Ven, 1993). The decline accelerated over time with the development of more effective drainage and pumping technologies and the lowering of groundwater levels. At present, $8 \%$ of the surface of the Netherlands is covered by peat (Fig. 1.1). Of this area, $82 \%$ is permanent grassland for dairy farming with groundwater levels at $30-70 \mathrm{~cm}$ below soil surface (with regional differences), $7 \%$ is less intensively drained semi-natural grassland managed by nature conservation organizations, $5 \%$ is natural wetland with saturated topsoil with various vegetation types and $6 \%$ is covered by roads and buildings (Van den Born et al., 2016; Van Kekem, 2004).

Drained peat soils differ greatly from mineral soils in terms of physical and hydrological properties. The high organic matter content results in a low bulk density and load bearing capacity, depending on the amount and type of mineral material and on the compactness of the organic matter (Schothorst, 1982; Schwärzel et al., 2002). The volume of the organic matter is influenced by drainage, decomposition and compaction by cattle and machinery. Also the hydrology of drained peat soils is influenced by its high organic 
matter content. Despite the generally narrow parcels surrounded by ditches, the topsoil may be very dry and the groundwater level may be low during periods of precipitation deficit. One cause is the low horizontal permeability of peat soils that results in extremely low water infiltration from the ditches (c. $1 \mathrm{~mm} \mathrm{day}^{-1}$ ) (Schothorst, 1982), even when the ditch water level is decimetres higher than the groundwater level, which typically occurs in summer. Another cause is the high hydrophobicity of dry peat soil that impedes vertical infiltration of rain water in the soil matrix (Dekker and Ritsema, 2000).

\subsubsection{New challenges to peat grassland management}

During the long history of grassland-based dairy farming in the Dutch peat districts, a characteristic cultural landscape with natural values such as habitats for meadow birds was created (Beintema, 1986; Van de Ven, 1993). However, this landscape is now mostly below sea level as a result of soil subsidence. At the current peat decomposition and soil subsidence rate, most of the Dutch peatlands will have disappeared within two centuries (Rienks et al., 2002). With the growing awareness of climate change and the high infrastructural costs on these unstable soils, the pressure from society to reduce peat decomposition is increasing, as is the requirement to care for other ecosystem services related to biodiversity and water quality (Van den Born et al., 2016). Following the Dutch Climate Deal (Ministry of Economic Affairs and Climate Policy, 2019), in peat areas the yearly emission is to be reduced with c. 25\% by 2030 compared to 1990 .

Thus, the traditional dairy farming based on continuous drainage is challenged to prioritize supporting and regulating ecosystem services at the same level as or in some places even above the provisioning ecosystem services. A less intensive, more nature inclusive and regenerative farming type (Erisman et al., 2016; Schreefel et al., 2020) that is better adapted to higher groundwater levels is seen as a solution for the medium term, as already in progress in different projects in the western peat region (Pijlman et al., 2018; Strootman et al., 2020; Vogelzang et al., 2004) (www.proeftuinkrimpenerwaard.nl, www.ktczegveld.nl/hoogwaterboerderij). In these projects, a set of measures is developed and implemented by researchers and advisers in close cooperation with farmers and local authorities, who indeed see the need for a transition in land use and are willing to realize it. In other areas, the agricultural production function is minimised by converting former dairy grasslands into (semi-)natural grasslands with higher groundwater levels and 
reduced grass production. In places where grazing, mowing and manuring occurs, this is done at low intensity to limit negative impacts on flora and fauna.

\subsection{Ecosystem services}

Ecosystem services (Costanza et al., 1997; Fisher et al., 2009; MEA, 2005) are the benefits that people derive from ecosystems to meet physiological, economic and non-material needs. The concept provides a framework to assess and compare situations, for example land management types, in an integral way and from a sustainability perspective. Soils deliver many ecosystem services (Adhikari and Hartemink, 2016; Dominati et al., 2010; Rutgers et al., 2012; Wall et al., 2012). In soil, the living organisms are the main actors in ecological interactions driven by the natural abiotic and biotic conditions and by human interferences (Bardgett and Cook, 1998; Brussaard, 2012; Brussaard et al., 1997; Creamer et al., 2016; De Vries et al., 2013; Lavelle et al., 2006; Swift et al., 2004; Van Eekeren et al., 2010).

The distinction between supporting, regulating and provisioning ecosystem services (MEA, 2005) can be used to assess effects of land use and land management measures in drained peat grasslands. The challenges to agriculture on peatland as increasingly required by society and by the agricultural sector itself are (1) to maintain and support aboveground and belowground biodiversity (supporting ecosystem services), (2) to reduce soil subsidence and $\mathrm{CO}_{2}$ emissions and to take care of water quality and quantity (regulating ecosystem services), and (3) to produce enough agricultural output for a healthy economic basis at farm level (provisioning ecosystem services). These main ecosystem services of drained peat grasslands, i.e. support of biodiversity, climate regulation, water regulation and grass production, are central in this thesis and are further described in Box 1.1.

\section{BOX 1.1 Ecosystem services of peat grasslands}

\section{Support of biodiversity}

Similarly to most other soil types, drained peat soils harbour a complex community of organisms including microbes (bacteria, fungi and protozoa), nematodes, enchytraeids, microarthropods and earthworms (Bardgett, 2005; Rutgers et al., 2009), and are also a habitat for specific flora and insects, especially where restoration measures were taken (Berendse et al., 1992; Van Dijk et al., 2007). The soil community is the base for 
organisms aboveground such as meadow birds (Beintema et al., 1991; Onrust, 2017). A large part of the European meadow bird population feeds and reproduces in the Dutch peat districts, but a decline in bird numbers is observed since c. 1940 due to the intensification of farming practices (Beintema, 1986; Kentie et al., 2015; Kruk et al., 1996; Vickery et al., 2001) that resulted in reduced food availability. Abundance of soil invertebrates and insects and their accessibility for meadow birds depend on a range of factors including the availability of fresh organic matter, floral diversity, vegetation structure, soil structure and soil moisture (Atkinson et al., 2005; Onrust et al., 2019; Vickery et al., 2001).

\section{Climate regulation, water regulation}

Drainage turns peat areas into a source of $\mathrm{CO}_{2}$ due to augmented peat decomposition and mineralization under aerobic soil conditions (Brouns, 2016; Joosten, 2011; KasimirKlemedtsson et al., 1997; Kluge et al., 2008). Net decomposition causes gradual subsidence of the peat areas in the Netherlands (Schothorst, 1977; Van den Akker et al., 2008) that are currently already situated below sea level (Van de Ven, 1993). The increasing difference between sea level and groundwater level impairs the possibilities for climate adaptation of these areas, complicates the drainage itself and may locally result in salinization. The reduction of peat mineralization is therefore becoming an urgent political topic with potentially large regional economic and social consequences (Strootman et al., 2020; Van den Born et al., 2016). In addition, high soil $\mathrm{N}$ and water contents may increase the emission of the greenhouse gases nitrous oxide (Van Beek et al., 2004a; Velthof and Oenema, 1995) and methane (Säurich et al., 2019; Van den Polvan Dasselaar et al., 1999).

The water quality and quantity regulation by soils includes the reduction of eutrophication, that affects the habitat function (Bobbink et al., 1998), and the prevention of floods by infiltration of rain water in the soil matrix (Newell Price et al., 2014).

\section{Grass production}

Dairy production in the Netherlands has traditionally a large cultural and economic importance. For example, famous dairy products such as Gouda cheese originate from the Dutch peat districts. At present, milk production is mainly based on roughage from permanent grasslands, with some additional concentrate feed from outside the region. Most farmers fertilize their grasslands with slurry manure and inorganic $\mathrm{N}$ fertilizer. Due to peat mineralization and high soil $\mathrm{N}$ supply that adds to the fertilizer $\mathrm{N}$, grass yields on 
drained peat are high in comparison to mineral soils (Vellinga and André, 1999). However, high soil mineral $\mathrm{N}$ content may also lead to $\mathrm{N}$ losses as nitrous oxide (Van Beek et al., 2004a) and to high grass $\mathrm{N}$ content, which in turn results in high urea- $\mathrm{N}$ excretion by cows and subsequent ammonia emission (Edouard et al., 2019).

\subsection{An integral approach to the ecosystem services of peat grasslands}

The greenhouse gas emission of peatlands is to be reduced. At the same time, decisions on which measures to take should be preceded by evaluation of other effects, as the wellbeing of society not only depends on a stable climate, but also on sustainable agricultural production, a healthy, diverse and well-functioning ecosystem and a clean and safe environment.

Numerous studies have been carried out about effects of peatland management on specific soil ecosystem components or processes, mainly in relation to $\mathrm{C}$ and $\mathrm{N}$ fluxes and rewetting drained peat grasslands for nature conservation (Ausec et al., 2009; Brouns, 2016; Hoekstra et al., 2019; Kools, 2006; Onrust, 2017; Pijlman et al., 2019; Rashid, 2013; Van Beek, 2007; Van de Riet et al., 2013; Van Dijk et al., 2009; Wasilewska, 2006). However, there is a lack of integral information on effects of management on soil biotic and abiotic quality in relation to ecosystem services in peat grasslands, which is needed for a sustainable land use (Breure et al., 2005) and for the transition towards a regenerative agriculture that combines provisioning ecosystem services with supporting and regulating ecosystem services. Therefore, an exploration of the delivery of ecosystem services by peat grasslands is first needed: what is the starting point and what can we learn from the current variation in soil biotic and abiotic quality across peat grasslands with different management and land use types? Thereafter, management measures can be evaluated with this integral ecosystem services approach to provide guidance to local actors, such as farmers, nature conservation organizations and policy-makers, to further develop and implement sustainable land use.

\subsection{Objective and research questions}

The complex mix of demands from society on peatland in general and dairy grasslands in particular calls for an integral research and management approach. This approach should 
evaluate the current delivery of ecosystem services and effects of specific land management measures that can potentially be used in the field. As the soil is a key player in many processes, the objective of this thesis is to get insight in the soil biotic and abiotic quality of peat grasslands in relation to the ecosystem services support of biodiversity, climate regulation, water regulation and grass production, and to evaluate the effects of land management measures from this integral perspective. Within this objective, the following research questions will be addressed in each of the following four chapters:

1. What are the soil biotic and abiotic properties and related provision of ecosystem services of grasslands across the peat region and to what extent do the land use types agricultural production (dairy grasslands) and nature conservation (semi-natural grasslands) differ?

2. Can soil biotic and abiotic properties of dairy grasslands be used to predict the variation in grass yield across the peat region and indicate ways to reduce $\mathrm{N}$ losses?

3. Are the soil biotic and abiotic properties and soil $\mathrm{N}$ supply of dairy grasslands on peat influenced by minerals that affect the soil $\mathrm{Ca}: \mathrm{Mg}$ ratio and $\mathrm{pH}$ ?

4. What are the effects of inorganic and organic fertilizers on soil quality in relation to ecosystem services in dairy grassland on peat that has a biodiversity goal?

\subsection{Thesis outline}

Chapter 2, Soil ecology and ecosystem services of dairy and semi-natural grasslands on peat, explores differences and similarities of soil biotic and abiotic quality and delivery of ecosystem services in two land use types: twenty conventionally managed dairy grasslands and twenty semi-natural grasslands with a higher groundwater level, a lower nutrient input and less intensive mowing and grazing regime. This study is carried out with a comprehensive data set of soil biological, chemical and physical properties supplemented with botanical and management data.

There is currently no prediction tool for $\mathrm{N}$ mineralization of dairy grassland on peat, resulting in a mismatch between $\mathrm{N}$ mineralization, $\mathrm{N}$ fertilization and grass $\mathrm{N}$ uptake, and leading to potentially large $\mathrm{N}$ losses. The aim of Chapter 3, Predicting soil $\mathrm{N}$ supply and yield parameters in peat grasslands, is to relate grass $\mathrm{N}$ uptake in dairy grasslands to soil properties, including site-specific $\mathrm{N}$ mineralization calculated with soil ecological data. Measurements were carried out in twenty dairy grasslands and results are based on 
correlative relationships using stepwise linear regression with permutation tests to determine model significance.

Chapter 4, Effects of Ca:Mg ratio and $\mathrm{pH}$ on soil chemical, physical and microbiological properties and grass $N$ yield in drained peat soil, investigates whether the positive relationship between unfertilized grass $\mathrm{N}$ yield and the natural variation in soil $\mathrm{Ca}: \mathrm{Mg}$ ratio that was found in Chapter 3 can be reproduced in a factorial experiment and whether effects can be explained from chemical, physical and microbiological soil properties. A field experiment was carried out during three years on three grasslands with different initial soil $\mathrm{Ca}: \mathrm{Mg}$ ratios, in which the $\mathrm{Ca}: \mathrm{Mg}$ ratio was manipulated with $\mathrm{Ca}$ or $\mathrm{Mg}$ containing minerals, with or without effect on $\mathrm{pH}$.

Chapter 5, Effects of organic and inorganic fertilizers on soil properties related to the regeneration of ecosystem services in peat grasslands, evaluates the effects of various fertilizers on soil properties and aboveground parameters in relation to ecosystem services of peat grassland. In a field experiment, four organic fertilizers and two inorganic fertilizers were applied to grassland during three consecutive growing seasons. Fertilizer application was based on $120 \mathrm{~kg}$ total $\mathrm{N} \mathrm{ha}^{-1} \mathrm{yr}^{-1}$, a low rate for conventional dairy production grasslands but common in grasslands under agri-environment schemes.

In Chapter 6, General discussion, I discuss and synthesize the main findings of the research described in Chapters 2 to 5 from the perspective of the ecosystem services of peat grasslands: support of biodiversity, climate regulation, water regulation and grass production. I also suggest new research directions and explore possibilities for implementation in the management of grasslands on peat. 



\section{Chapter 2}

\section{Soil ecology and ecosystem services of dairy and semi-natural grasslands \\ on peat}

Published as:

Deru, J.G.C., Bloem, J., de Goede, R., Keidel, H., Kloen, H., Rutgers, M., van den Akker, J., Brussaard, L., van Eekeren, N., 2018. Soil ecology and ecosystem services of dairy and seminatural grasslands on peat. Applied Soil Ecology 125, 26-34.

https://doi.org/10.1016/j.apsoil.2017.12.011 



\section{Abstract}

Peat wetlands are of major importance for ecosystem services such as carbon storage, water regulation and maintenance of biodiversity. However, peat drainage for farming leads to $\mathrm{CO}_{2}$ emission, soil subsidence and biodiversity losses. In the peat areas in the Netherlands, solutions are sought in reducing drainage, adapting farming to wetter soils, and converting productive dairy grasslands to less intensively managed semi-natural grasslands. Our objective was to compare the soil ecology and related ecosystem services of dairy and semi-natural grasslands on peat soils (Terric Histosols). Soil biotic and abiotic parameters were measured in twenty dairy and twenty semi-natural sites, with particular focus on (i) soil faunal diversity (ecosystem service maintenance of biodiversity), (ii) $\mathrm{CO}_{2}$ emission (climate regulation), (iii) water infiltration (water regulation) and (iv) soil fertility (grass production). Mean soil faunal taxonomic richness per site (alpha diversity) was higher in dairy grasslands compared to semi-natural grasslands. However, the total observed number of taxa (gamma diversity) was $13 \%$ lower for soil fauna and $21 \%$ lower when including plant species. Potential $\mathrm{C}$ mineralization rate in the topsoil - used as a proxy for $\mathrm{CO}_{2}$ emission - was not influenced by land use but was limited by drought. Additionally, potential $\mathrm{C}$ mineralization depended on different $\mathrm{C}$ sources and microbial groups in the two grassland types. Water infiltration rate differed by a factor of five between land use types (dairy > semi-natural), and correlated with soil porosity. As expected, soil fertility was higher in dairy than in semi-natural grasslands. However, potential $\mathrm{N}$ mineralization was similar in dairy and semi-natural grasslands and was correlated negatively with bacterial biomass apparently indicating $\mathrm{N}$ immobilization, and positively with bacterial growth that depended on labile $\mathrm{C}$ and $\mathrm{N}$ in soil. Our study on peat soils shows that dairy versus semi-natural grassland use influences biodiversity, climate regulation, water regulation and (potential for) grassland production. We conclude with recommendations for land management to optimize the delivery of those ecosystem services.

\section{Keywords}

Grassland; Histosols; biodiversity; C mineralization; $\mathrm{N}$ mineralization; water infiltration 


\subsection{Introduction}

Peat wetlands worldwide deliver important ecosystem services such as carbon (C) storage, maintenance of biodiversity and water regulation (Maltby and Immirzi, 1993; Verhoeven and Setter, 2010). In the river deltas of the Netherlands, land reclamation for agriculture by peat drainage and peat harvesting for fuel was carried out from the Middle Ages onwards (Van de Ven, 1993) and caused soil subsidence, resulting in a decline of peatcovered land area. At present, $8 \%$ of the surface of the Netherlands is covered by peat soil and is in use for grassland based dairy farming (82\%), semi-natural grasslands (7\%), nature (5\%), and infrastructure, buildings and surface water (De Vries, 2004; Van den Born et al., 2016). For productive dairy grasslands, the groundwater level is kept well below the soil surface (generally $30-70 \mathrm{~cm}$ ) by drainage. A major drawback of this land use is net decomposition of organic matter in the oxic topsoil, resulting in carbon dioxide $\left(\mathrm{CO}_{2}\right)$ emission (Kasimir-Klemedtsson et al., 1997; Van den Akker et al., 2008), soil subsidence (Schothorst, 1977) and high infrastructural costs (Van den Born et al., 2016). Moreover, additional issues related to dairy grasslands on drained peat have been reported: loss of floral and faunal aboveground biodiversity, including meadow birds (Beintema, 1986; Lamers et al., 2002), and eutrophication (Bobbink et al., 1998).

These observations, together with (inter)national agendas on biodiversity and climate, lead to increasing pressure from society on agricultural peat areas to maintain biodiversity, reduce $\mathrm{CO}_{2}$ emission and provide water storage capacity (Van den Born et al., 2016). Thus, peatlands are challenged to deliver not only provisioning but also regulating and supporting ecosystem services (MEA, 2005). Solutions are seen in increasing the area of (semi-)natural grasslands and natural peat vegetation at higher groundwater level, or in "nature-inclusive" agriculture with reduced drainage intensity, use of submerged tile drains and adaptation to wetter soils (Erisman et al., 2016; Van den Akker et al., 2008; Van den Born et al., 2016). Such changes should result in delivery of ecosystem services closer to the societal needs. For policy choices on land management in accordance with these needs, it is necessary to know how the delivery of ecosystem services changes following land use and land management changes. Dutch peatland has been drained intensively for centuries, and hence, the implications constitute a valuable case study for the development of sustainable use of peat soils in both the Netherlands and other countries. 
Differences between peat grasslands managed for dairy production or for nature restoration have been studied in the Netherlands in relation to specific ecosystem components or processes, such as floral diversity (Berendse et al., 1992; Van Dijk et al., 2007), meadow birds (Schekkerman and Beintema, 2007; Verhulst et al., 2007), or soil biology, soil chemistry and peat decomposition (Brouns et al., 2016; Van de Riet et al., 2013; Van Dijk et al., 2009). However, because of the variety in delivery of ecosystem services with possible trade-offs, there is a need for integral knowledge across different land uses (Breure et al., 2005). Within the peat area, the monitoring programme of the Dutch Soil Quality Network covered only the land use "dairy farming", and did not include comparisons with other land use types (Rutgers et al., 2009). The objective of this paper is therefore to provide a comparison of the soil ecology and the related provision of ecosystem services of peat grasslands either used for grass production ("dairy grasslands") or for nature restoration and conservation ("semi-natural grasslands").

We selected dairy and semi-natural grasslands on peat (27-65\% organic matter) and measured soil biotic and abiotic parameters, and botanical composition. To limit the influence of site-specific properties twenty replicates (grasslands) per land use type were sampled. Also, to minimize short-term effects of nutrient and C inputs to the soil, measurements were carried out during spring, before application of manure. In the interpretation we focus on the following parameters and ecosystem services: (i) soil faunal diversity (ecosystem service maintenance of biodiversity), (ii) $\mathrm{CO}_{2}$ emission (climate regulation), (iii) water infiltration (water regulation) and (iv) soil fertility (grass production). We hypothesize that the higher nutrient input in dairy grasslands leads to soil faunal communities with a lower taxonomic richness. In addition, we hypothesize that dairy grassland soils have higher microbial activity and $\mathrm{CO}_{2}$ emission due to higher $\mathrm{C}$ inputs (plant residues, cattle manure) and more oxic conditions, but have less crumb structures and lower water infiltration rates than semi-natural grasslands due to compaction by machinery and livestock. Finally, we expect dairy grassland soils to have higher $\mathrm{pH}$, contain more plant available nutrients and have higher potential $\mathrm{N}$ mineralization than seminatural grasslands. 


\subsection{Materials and methods}

\subsubsection{Study sites}

In the western peat district of the Netherlands, we selected twenty replicates for each grassland type studied: on commercial dairy farms ("dairy grasslands") and in areas owned and managed by nature conservation organizations ("semi-natural grasslands"). Selection criteria were: (i) situated on peat soil (Terric Histosol; FAO, 2015) (ii) minimum sward age of ten years, (iii) summer ditch water level within the range of $20-60 \mathrm{~cm}$ below soil surface and (iv) no major changes in management (drainage, fertilization, stocking) in the past five years. At each site, an experimental plot $(6 \mathrm{~m} \times 9 \mathrm{~m})$ was laid out. During the experimental year, the plots remained unfertilized, ungrazed and unmown until soil sampling.

The dairy grasslands had an average ditch water level (summer) of $49 \mathrm{~cm}$ below soil surface (Table 2.1), ranging from 30 to $60 \mathrm{~cm}$, and a conventional management with a history of mixed grazing and cutting. The year before the measurements, the dairy

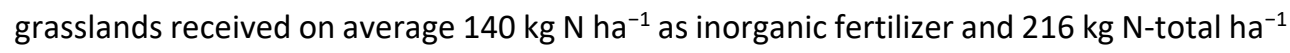
as cattle manure (mainly slurry manure; excluding excretion during grazing).

In the semi-natural grasslands, mean ditch water level was $40 \mathrm{~cm}$ below soil surface (range 20-60 cm), significantly higher than in dairy grasslands $(P<0.01$; Table 2.1). Most of the semi-natural grasslands were extensively grazed by sheep or young cattle, cut once or twice a year after the chick season of meadow birds and had a low manure input of on average $43 \mathrm{~kg} \mathrm{~N}$-total ha $\mathrm{har}^{-1} \mathrm{yr}^{-1}$ mainly as solid cattle manure (excluding excretion during

Table 2.1 Management and plant parameters of dairy $(n=20)$ and semi-natural $(n=20)$ grasslands on peat (means, standard deviations, $P$-values). Plant species in Supplementary Table S2.1. $P$-values $\leq 0.05$ in bold.

\begin{tabular}{|c|c|c|c|c|c|c|}
\hline \multirow[b]{2}{*}{ Parameter } & \multirow[b]{2}{*}{ Unit } & \multicolumn{2}{|c|}{ Dairy } & \multicolumn{2}{|c|}{ Semi-natural } & \multirow[t]{2}{*}{$P$-value } \\
\hline & & mean & s.d. & mean & s.d. & \\
\hline \multicolumn{7}{|l|}{ Historical management } \\
\hline Ditch water level (summer) & $\mathrm{cm}$ below soil surface & 49 & 8 & 40 & 14 & 0.009 \\
\hline $\mathrm{N}$ from organic manure & $\mathrm{kg} \mathrm{N} \mathrm{ha}^{-1} \mathrm{yr}^{-1}$ & 216 & 55 & 43 & 50 & $<0.001$ \\
\hline $\mathrm{N}$ from mineral fertilizer & $\mathrm{kg} \mathrm{N} \mathrm{ha}^{-1} \mathrm{yr}^{-1}$ & 140 & 91 & 0 & 0 & $<0.001$ \\
\hline Number of grass cuts & $\mathrm{n} \mathrm{yr} \mathrm{r}^{-1}$ & 2.7 & 0.8 & 1.1 & 0.5 & $<0.001$ \\
\hline \multicolumn{7}{|l|}{ Botanical composition } \\
\hline Monocotyledon soil cover & $\%$ & 82.5 & 10.6 & 55.1 & 21.1 & $<0.001$ \\
\hline Dicotyledon soil cover & $\%$ & 8.8 & 10.0 & 22.6 & 16.2 & 0.002 \\
\hline Number of plant species & $\mathrm{n}$ & 15.2 & 3.2 & 14.8 & 5.3 & 0.104 \\
\hline
\end{tabular}


grazing). Three grasslands were not manured nor grazed, but mown once a year to keep the vegetation open and to export nutrients.

\subsubsection{Vegetation survey}

Botanical composition was measured in June 2010 according to the Braun-Blanquet coverabundance method (Westhoff and van der Maarel, 1978). Before statistical analyses, Braun-Blanquet scores were replaced with a fully numerical 1-9 scale (Van der Maarel, 1979).

\subsubsection{Soil measurements}

All soil sampling and in situ measurements were carried out between 20 and 28 April 2010. In each plot, a bulk sample consisting of c. 50 randomly taken soil cores $(0-10 \mathrm{~cm}, \varnothing 2.3$ $\mathrm{cm}$ ) was collected. This sample was sieved through $1 \mathrm{~cm}$ mesh, homogenized and split into sub-samples for biotic (nematodes, microbes and microbial processes) and abiotic (chemical composition, particle size distribution and gravimetric water content) analysis. Separate samples were taken for soil meso- and macrofauna and additional soil physical and chemical measurements.

\subsubsection{Soil biological measurements}

Fungal biomass, bacterial biomass, bacterial growth rate $\left(\left[{ }^{3} \mathrm{H}\right]\right.$ thymidine and $\left[{ }^{14} \mathrm{C}\right]$ leucine incorporation into bacterial DNA and proteins), potential $\mathrm{C}$ mineralization and potential $\mathrm{N}$ mineralization were determined for each site as described in Van Eekeren et al. (2010), except that samples were incubated at field-moisture content.

Nematodes, enchytraeids, earthworms and microarthropods were sampled and determined for each site as described in Van Eekeren et al. (2010). Additionally, nematode channel index, enrichment index and structure index (Ferris et al., 2001) were calculated with the relative abundance data using NINJA (Sieriebriennikov et al., 2014). For earthworms, the number of species per plot was corrected for small sample size with Fischer's alpha diversity index (Fisher et al., 1943). Microarthropods were counted, identified to species and assigned to feeding guilds.

Diversity and abundance indices were calculated. The Shannon species diversity index $(H)$ (Shannon, 1948) was calculated separately for each soil faunal group and experimental 
plot. Furthermore, we calculated one combined soil faunal taxonomic richness index for the groups together, per plot. The number of taxa was first standardized per group by subtracting the mean and dividing by the standard deviation $(n=40)$, resulting in a range of values with mean $=0$ and standard deviation $=1$ (Wagg et al., 2014). These standardized values were then divided by four (i.e. the number of faunal groups) and summed up to a single "combined soil faunal taxonomic richness index" with mean $=0$. The same procedure was used for calculation of a "combined soil faunal abundance index".

\subsubsection{Soil physical measurements}

In each plot, five undisturbed $100 \mathrm{~cm}^{3}$ soil cores were taken in the $5-10 \mathrm{~cm}$ soil layer. Bulk density, water content at water saturation and at pF 2.0 were determined using the ISO11274 method. Air content at pF 2.0 was calculated from the weight difference between samples at pF 2.0 and water-saturated samples. Actual soil water content was determined in the 0-10 cm bulk sample by drying two $30 \mathrm{~g}$ sub-samples at $105{ }^{\circ} \mathrm{C}$ to constant weight.

Soil penetration resistance was measured using an electronic penetrometer (Eijkelkamp, Giesbeek, The Netherlands) with $2.0 \mathrm{~cm}^{2}$ penetration surface and a $60^{\circ}$ apex angle. Cone resistance was recorded per $\mathrm{cm}$ of soil depth and expressed as the average of 10 penetrations per layer $(0-10,10-20$ and $20-30 \mathrm{~cm})$. Load bearing capacity was measured at 10 randomly chosen spots in each plot using a penetrometer $\left(5.0 \mathrm{~cm}^{2}\right.$ penetration surface, $60^{\circ}$ apex angle), and expressed as the maximum force $(\mathrm{N})$ needed to push the cone through the sod.

Soil particle size distribution was measured in $2 \mathrm{~g}$ sub-samples of the $0-10 \mathrm{~cm}$ bulk sample as described in Van Eekeren et al. (2010). Clay and silt percentages were then corrected according to Buurman et al. (2001) for underestimation (clay) and overestimation (silt) by the laser diffraction method compared to the pipette method. Finally, values were recalculated to percentage of total soil weight including organic matter.

Soil structure in the $0-10$ and $10-20 \mathrm{~cm}$ layers (distribution of crumbs, sub-angular and angular elements, and density of macropores and roots) and water infiltration rate into the soil were measured in situ as described in Van Eekeren et al. (2010). 


\subsubsection{Soil chemical measurements}

For each site, soil from the $0-10 \mathrm{~cm}$ bulk sample was oven-dried at $40{ }^{\circ} \mathrm{C}$ prior to analysis of acidity $\left(\mathrm{pH}_{\mathrm{KCl}}\right)$, organic matter $(\mathrm{SOM})$, total carbon $\left(\mathrm{C}_{\text {total }}\right)$, total nitrogen $\left(\mathrm{N}_{\text {total }}\right)$, total phosphorus $\left(\mathrm{P}_{\text {total }}\right)$ and ammonium-lactate-extractable $\mathrm{P}\left(\mathrm{P}_{\mathrm{AL}}\right)$, as described in Van Eekeren et al. (2010).

Water soluble carbon (WSC) and hot water extractable carbon (HWC) were analyzed according to Ghani et al. (2003). Field-moist soil from the 0-10 cm bulk sample was extracted with $30 \mathrm{ml}$ distilled water for $30 \mathrm{~min}$, centrifuged for $20 \mathrm{~min}$ and filtered. The filtrate was used to measure WSC. Next, the sediments in the centrifuge tubes were shaken with a fresh amount of $30 \mathrm{ml}$ distilled water for $10 \mathrm{~s}$ and left for $16 \mathrm{~h}$ in a hot-water bath at $80{ }^{\circ} \mathrm{C}$. After filtration, the filtrate was used to measure HWC. Both HWC and WSC were expressed per g dry soil.

Potentially mineralizable $\mathrm{N}$ was determined by anaerobic incubation of $16 \mathrm{~g}$ of soil from the 0-10 cm bulk sample as described in Van Eekeren et al. (2010).

Finally, soil samples from the 0-20 cm layer were analyzed for cation exchange capacity (CEC), Ca, Mg and $\mathrm{K}$ saturation, and nitrate concentration with a Mehlich 3 extractant by Soil Tech Solutions (www.soiltech.nl).

\subsubsection{Statistical analyses}

The measurements yielded a database with 147 soil parameters measured in forty sites. Where necessary, parameter values were log-transformed to obtain a normal distribution.

First statistical analyses were carried out in Genstat (18 ${ }^{\text {th }}$ edition, VSN international, UK). For each parameter, we tested for the effect of land use ("dairy" versus "seminatural") by one-way ANOVA. Control of false positive results due to the large number of parameters tested was done according to Benjamini and Hochberg (1995) with the total list of $P$-values from the ANOVAs. For the whole group of tests, maximum $P$-value for a difference in an individual parameter was 0.024 at $\alpha=5 \%$ (significant difference), and 0.056 at $\alpha=10 \%$ (trend). When correlations between parameters were expected, Pearson sample correlations and their significances were determined.

Additionally, structural equation modeling (SEM) was carried out in $\mathrm{R}$ with the lavaan package (Rosseel, 2012). SEM was used to improve our mechanistic understanding by finding determinant (explanatory) soil quality factors for the following dependent 
parameters: (i) combined index of soil faunal taxonomic richness, (ii) potential C mineralization, (iii) water infiltration, and (iv) potential $\mathrm{N}$ mineralization. For each dependent parameter we started with a hypothesis model, built with explanatory parameters and pathways based on our knowledge of soil processes. We then improved and simplified the initial model by adding omitted significant pathways based on the modification index (mi) and by excluding non-significant pathways $(P>0.05)$. The quality of the total models was assessed using the $\mathrm{Chi}^{2}$ statistic, the root mean square error of approximation value (RMSEA) and the Akaike information criteria (AIC) (Kline, 2016). An adjusted $\mathrm{Chi}^{2}$-square probability was calculated with the Monte Carlo MCX2 function to correct for the limited sample size $(n=40)$ (Shipley, 2016).

\subsection{Results}

\subsubsection{Botanical composition}

Monocotyledons were dominant in both dairy and semi-natural grasslands (Table 2.1). Dairy grasslands had a higher soil cover of monocotyledons and a lower cover of dicotyledons than semi-natural grasslands. The most common plant species were Lolium perenne L., Poa trivialis L. and Poa pratensis L. in dairy grasslands (in decreasing order of presence; Supplementary Table S2.1) and Ranunculus repens L., P. trivialis, L. perenne and Holcus lanatus L. in semi-natural grasslands. The mean number of plant species did not differ between grassland types. However, the twenty dairy grasslands together (gamma diversity; Whittaker, 1960) comprised less plant species than the twenty semi-natural grasslands: 34 versus 64, respectively (all sites: 72 species) (Fig. 2.1).

\subsubsection{Soil biotic parameters}

Microbial parameters did not differ between land use types (Table 2.2). Bacterial biomass tended to be lower $(P=0.052)$ in dairy grasslands.

Total soil faunal abundance and taxonomic richness were higher in dairy than in seminatural grasslands (Table 2.3; Table S2.2). Differences in abundance were mainly caused by nematodes, earthworms and microarthropods, and differences in taxonomic richness by nematodes and enchytraeids. The combined soil faunal abundance index correlated positively with soil fertility ( $\mathrm{P}_{\text {total }}$, nitrate, $\mathrm{pH}$ ) and soil structure (soil crumbs, root density) 


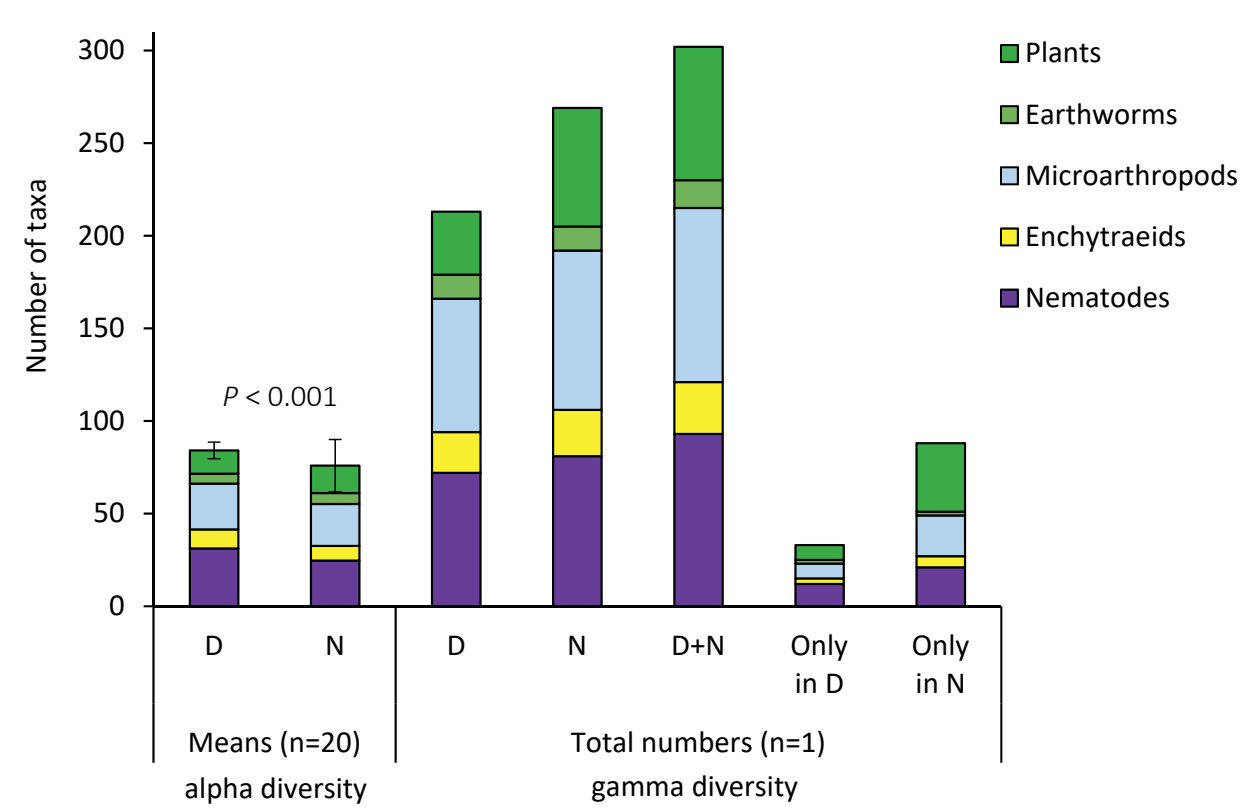

Figure 2.1 Number of plant and soil faunal (nematode, enchytraeid, microarthropod, earthworm) taxa in dairy (D) and semi-natural (N) grasslands on peat. Error bars of taxa means represent the standard deviation for the five groups together $(n=20)$. Total numbers within all samples were used to calculate gamma diversity. The column 'Only in $\mathrm{D}$ ' represents the number of taxa present in dairy but not in semi-natural grasslands, and vice versa for 'Only in N'.

(Tables 2.4 and 2.5). The total number of observed soil faunal taxa in this study (gamma diversity) was 230, of which 179 taxa (78\%) were present in the dairy grasslands and 205 taxa (89\%) in the semi-natural grasslands (Fig. 2.1). The soil faunal taxonomic richness did not correlate significantly with the number of plant species.

Nematodes were more abundant in dairy than in semi-natural grasslands (Table 2.3) and correlated positively with soil abiotic parameters, especially nitrate (Table 2.5). No difference between the land use types was found in maturity and structure indices (Table S2.2). The enrichment index was higher in dairy grasslands $(P=0.016)$, whereas the channel index tended to be lower $(P=0.046)$. In dairy grasslands, the proportions of bacterivorous and predatory nematodes were higher than in semi-natural grasslands, whereas the proportion of herbivorous nematodes was lower. The abundance of bacterivorous nematodes was positively correlated with $\mathrm{pH}(r=0.69)$, nitrate $(r=0.65)$ and soil crumbs $(r=0.74)$ (all at $P<0.001)$. 
Enchytraeid abundance did not differ between grassland types (Table 2.3) but Fridericia species were more abundant in dairy grasslands, where they were dominant (Table S2.2). Consequently, enchytraeid mean body weight was higher in dairy grasslands. The abundance of Fridericia enchytraeids was positively correlated with soil $\mathrm{pH}(\mathrm{r}=0.68$; $P<0.001)$.

Table 2.2 Soil microbial parameters of dairy $(n=20)$ and semi-natural $(n=20)$ grasslands on peat $(0-10$ $\mathrm{cm})$ (means, standard deviations, $P$-values).

\begin{tabular}{|c|c|c|c|c|c|c|}
\hline \multirow[b]{2}{*}{ Parameter } & \multirow[b]{2}{*}{ Unit } & \multicolumn{2}{|c|}{ Dairy } & \multicolumn{2}{|c|}{ Semi-natural } & \multirow[t]{2}{*}{$P$-value ${ }^{\dagger}$} \\
\hline & & mean & s.d. & mean & s.d. & \\
\hline Fungal biomass & $\mu g$ C.g dry soil ${ }^{-1}$ & 65.8 & 19.4 & 76.6 & 49.2 & 0.365 \\
\hline Percentage of active fungi & $\%$ hyphal length & 5.6 & 6.4 & 4.8 & 4.7 & 0.638 \\
\hline Bacterial biomass & $\mu g$ C.g dry soil ${ }^{-1}$ & 238.3 & 75.8 & 302.0 & 120.1 & 0.052 \\
\hline Thymidine incorporation & pmol.(g.h $)^{-1}$ & 62.3 & 27.5 & 63.5 & 48.4 & 0.318 \\
\hline Leucine incorporation & pmol.(g.h $)^{-1}$ & 1895 & 456 & 1998 & 836 & 0.981 \\
\hline Fungi:bacteria ratio & $\mathrm{g} \mathrm{g}^{-1}$ & 0.30 & 0.11 & 0.27 & 0.15 & 0.382 \\
\hline Metabolic quotient $\left(q \mathrm{CO}_{2}\right)$ & $\mu g$ C. $\mu g$ C $_{\text {micr }}{ }^{-1} \cdot$ week $^{-1}$ & 0.65 & 0.27 & 0.57 & 0.17 & 0.532 \\
\hline Potential C mineralization ${ }^{\ddagger}$ & $\mu g$ C.(g soil.wk) $)^{-1}$ & 183 & 58 & 203 & 66 & 0.310 \\
\hline Potential N mineralization ${ }^{\ddagger}$ & $\mu$ g N.(g soil.wk) $)^{-1}$ & 27.9 & 10.0 & 30.0 & 12.6 & 0.881 \\
\hline
\end{tabular}

${ }^{\dagger}$ maximum $P$-values for differences after correction for high number of parameters (see Methods): 0.024 at $\alpha=$ $5 \%$ (significant difference); 0.056 at $\alpha=10 \%$ (trend, italic).

${ }^{\ddagger}$ at field moisture

Table 2.3 Soil faunal abundance and taxonomic richness of dairy $(n=20)$ and semi-natural $(n=20)$ grasslands on peat (means, standard deviations, $P$-values). Data on trophic, functional and taxonomic groups in Table S2.2.

\begin{tabular}{|c|c|c|c|c|c|c|}
\hline \multirow[b]{2}{*}{ Parameter } & \multirow[b]{2}{*}{ Unit } & \multicolumn{2}{|c|}{ Dairy } & \multicolumn{2}{|c|}{ Semi-natural } & \multirow[t]{2}{*}{$P$-value ${ }^{\dagger}$} \\
\hline & & mean & s.d. & mean & s.d. & \\
\hline Total number of soil faunal taxa & $\mathrm{n}$ taxa & 71 & 4 & 61 & 12 & $<0.001$ \\
\hline \multicolumn{7}{|l|}{ Nematodes } \\
\hline Abundance & n $100 \mathrm{~g}^{-1}$ & 8597 & 2267 & 6221 & 2803 & 0.005 \\
\hline Taxonomic richness & $\mathrm{n}$ taxa & 31.2 & 2.8 & 24.7 & 6.1 & $<0.001$ \\
\hline \multicolumn{7}{|l|}{ Enchytraeids } \\
\hline Abundance & $n m^{-2}$ & 31642 & 9967 & 37354 & 10841 & 0.091 \\
\hline Taxonomic richness & $\mathrm{n}$ taxa & 10.3 & 2.1 & 7.9 & 3.0 & 0.007 \\
\hline \multicolumn{7}{|l|}{ Earthworms } \\
\hline Abundance & $\mathrm{n} \mathrm{m}^{-2}$ & 587 & 318 & 270 & 247 & 0.001 \\
\hline Taxonomic richness & $\mathrm{n}$ taxa & 5.4 & 1.9 & 5.9 & 2.9 & 0.598 \\
\hline \multicolumn{7}{|l|}{ Microarthropods } \\
\hline Abundance & $n m^{-2}$ & 81157 & 33830 & 42944 & 33282 & $<0.001$ \\
\hline Taxonomic richness & $\mathrm{n}$ taxa & 24.7 & 3.0 & 22.6 & 4.5 & 0.092 \\
\hline
\end{tabular}

${ }^{+}$maximum $P$-values for differences after correction for high number of parameters (see Methods): 0.024 at $\alpha=$ $5 \%$ (significant difference, bold); 0.056 at $\alpha=10 \%$ (trend, italic). 
Earthworms were c. twice as abundant in dairy than in semi-natural grasslands (Table 2.3), with a higher proportion of juveniles (Table S2.2). Earthworm density correlated positively with soil macropores and $\mathrm{pH}$ (Table 2.5 ). The proportions of epigeic and

Table 2.4 Soil abiotic parameters of dairy $(n=20)$ and semi-natural $(n=20)$ grasslands on peat (means, standard deviations, $P$-values). Additional parameters in Table S2.3.

\begin{tabular}{|c|c|c|c|c|c|c|}
\hline \multirow[b]{2}{*}{ Parameter } & \multirow[b]{2}{*}{ Unit } & \multicolumn{2}{|c|}{ Dairy } & \multicolumn{2}{|c|}{ Semi-natural } & \multirow[t]{2}{*}{$P$-value ${ }^{\dagger}$} \\
\hline & & mean & s.d. & mean & s.d. & \\
\hline \multicolumn{7}{|l|}{ Soil physical parameters } \\
\hline Crumbs $(0-10 \mathrm{~cm})$ & $\%$ & 79 & 15 & 46 & 27 & $<0.001$ \\
\hline Roots (at $10 \mathrm{~cm}$ depth) & $\mathrm{n} .400 \mathrm{~cm}^{-2}$ & 306 & 76 & 153 & 102 & $<0.001$ \\
\hline Macropores (at $10 \mathrm{~cm}$ depth) & $\mathrm{n} .400 \mathrm{~cm}^{-2}$ & 5.7 & 4.9 & 2.4 & 2.1 & 0.010 \\
\hline Water infiltration rate & $\mathrm{mm} \mathrm{min}-1$ & 31.6 & 32.0 & 6.2 & 7.9 & 0.001 \\
\hline Bulk density & $\mathrm{g} \mathrm{cm}^{-3}$ & 0.54 & 0.09 & 0.49 & 0.17 & 0.273 \\
\hline Field water content & Vol. \% & 51.7 & 5.0 & 57.8 & 9.9 & 0.019 \\
\hline \multicolumn{7}{|l|}{ Soil chemical parameters } \\
\hline Clay $(<2 \mu \mathrm{m})$ & g.100g soil ${ }^{-1}$ & 23.2 & 4.2 & 19.1 & 5.3 & 0.009 \\
\hline Organic matter (SOM) & g.100g soil ${ }^{-1}$ & 43.8 & 8.8 & 40.3 & 10.6 & 0.197 \\
\hline $\mathrm{pH}_{\mathrm{KCl}}$ & - & 4.8 & 0.3 & 4.4 & 0.5 & 0.002 \\
\hline$C_{\text {total }}$ & g. $100 \mathrm{~g} \mathrm{soil}^{-1}$ & 22.4 & 4.5 & 20.9 & 5.9 & 0.355 \\
\hline Hot water extractable C & $\mu g$ C.g soil ${ }^{-1}$ & 9309 & 1852 & 7282 & 1258 & $<0.001$ \\
\hline Water soluble $\mathrm{C}$ & $\mu g$ C.g soil ${ }^{-1}$ & 438 & 89 & 467 & 281 & 0.704 \\
\hline $\mathrm{N}_{\text {total }}$ & g.100g soil ${ }^{-1}$ & 2.01 & 0.46 & 1.77 & 0.39 & 0.073 \\
\hline Potentially mineralizable $\mathrm{N}$ & $\mu \mathrm{g}$ N.g soil ${ }^{-1}$ & 465 & 98 & 334 & 76 & $<0.001$ \\
\hline$P_{\text {total }}$ & g.100 g soil ${ }^{-1}$ & 0.73 & 0.11 & 0.53 & 0.13 & $<0.001$ \\
\hline Plant available $\mathrm{P}\left(\mathrm{P}_{\mathrm{AL}}\right)$ & $\mathrm{mg} \mathrm{P}_{2} \mathrm{O}_{5} \cdot 100 \mathrm{~g} \mathrm{soil}^{-1}$ & 52.7 & 22.7 & 26.4 & 16.2 & $<0.001$ \\
\hline
\end{tabular}

${ }^{+}$maximum $P$-values for differences after correction for high number of parameters (see Methods): 0.024 at $\alpha=$ $5 \%$ (significant difference, bold); 0.056 at $\alpha=10 \%$ (trend, italic).

Table 2.5 Significant Pearson correlations $(r ; n=40)$ between the abundance of nematodes, enchytraeids, microarthropods and earthworms and soil abiotic parameters in grasslands on peat.

\begin{tabular}{lccccc}
\hline & & \multicolumn{3}{c}{ Abundance of soil faunal group } \\
\cline { 3 - 6 } Soil abiotic parameter & $\begin{array}{c}\text { Combined } \\
\text { abundance index }\end{array}$ & Nematodes & Enchytraeids & arthropods & Earthworms \\
\hline$P_{\text {total }}$ & $0.67^{* * *}$ & $0.49^{* *}$ & n.s. & $0.60^{* * *}$ & $0.49^{* *}$ \\
Nitrate & $0.72^{* * *}$ & $0.68^{* * *}$ & n.s. & $0.73^{* * *}$ & $0.47^{* *}$ \\
$\mathrm{pH}_{\mathrm{KCl}}$ & $0.63^{* * *}$ & $0.56^{* * *}$ & n.s. & $0.37^{*}$ & $0.64^{* * *}$ \\
Field water content & $-0.41^{* *}$ & n.s. & n.s. & $-0.43^{* *}$ & $-0.33^{*}$ \\
Crumbs & $0.63^{* * *}$ & $0.57^{* * *}$ & n.s. & $0.62^{* * *}$ & $0.57^{* * *}$ \\
Roots & $0.53^{* * *}$ & $0.54^{* * *}$ & $-0.34^{*}$ & $0.71^{* * *}$ & $0.46^{* *}$ \\
Macropores & $0.44^{* *}$ & n.s. & $-0.40^{*}$ & $0.52^{* * *}$ & $0.70^{* * *}$ \\
\hline
\end{tabular}

$* P \leq 0.05 ; * * P \leq 0.01 ; * * * P \leq 0.001$ 
endogeic earthworms were similar in both grassland types. No anecic earthworms were found.

Microarthropods were nearly twice as abundant in dairy than in semi-natural grasslands (Table 2.3) and their density correlated positively with nitrate, $\mathrm{P}_{\text {total, }}$ root density and soil crumbs (Table 2.5). Fungivorous microarthropods were dominant in both grassland types and more abundant in dairy grasslands (Table S2.2). In dairy grasslands, the proportion of omnivorous microarthropods and of fungivorous grazers, but not browsers, was higher. In contrast, the proportion of herbivorous grazers, but not browsers, was lower.

\subsubsection{Soil abiotic parameters}

Dairy grasslands differed from semi-natural grasslands in soil structure, with more crumbs and higher numbers of macropores and roots, and a higher water infiltration rate (Table 2.4). Bulk density did not differ, but soil water content was lower in dairy grasslands. At pF 2, soil water and air contents did not differ between grassland types (Table S2.3). Penetration resistance was higher (significant below $10 \mathrm{~cm}$ depth) in dairy grasslands, as was load-bearing capacity. Dairy grasslands had slightly higher clay contents than seminatural grasslands. Soil $\mathrm{pH}, \mathrm{HWC}$, potentially mineralizable $\mathrm{N}, \mathrm{P}_{\text {total }}$ and $\mathrm{P}_{\mathrm{AL}}$ were higher in dairy grasslands. No differences were found for SOM, $\mathrm{C}_{\text {total, }} \mathrm{N}_{\text {total, }} \mathrm{C}: \mathrm{N}$ ratio or WSC.

\subsubsection{Ecosystem services}

SEM yielded four models that significantly explained variance in the parameters (i) combined index of soil taxonomic richness (ecosystem service maintenance of biodiversity); (ii) potential C mineralization (climate regulation); (iii) water infiltration (water regulation); and (iv) potential $\mathrm{N}$ mineralization (grass production) (Fig. 2.2).

The combined index of soil taxonomic richness was positively correlated with soil $\mathrm{pH}$ and root density, and root density was linked with percentage of grass cover and soil $\mathrm{N}_{\text {total }}$ (Fig. 2.2a). Potential C mineralization was positively correlated with soil water content and weakly, but significantly, to HWC (Fig. 2.2b). Higher HWC was found at higher $\mathrm{C}_{\text {total }}$ and root density. Water infiltration was positively correlated with number of macropores and percentage of soil crumbs, while macropores correlated with earthworm abundance, and soil crumbs with root density and soil pH (Fig. 2.2c). Potential $\mathrm{N}$ mineralization was 
negatively correlated with bacterial biomass but positively with thymidine incorporation, and was indirectly correlated with the amount of potentially mineralizable N (Fig. 2.2d).

a)

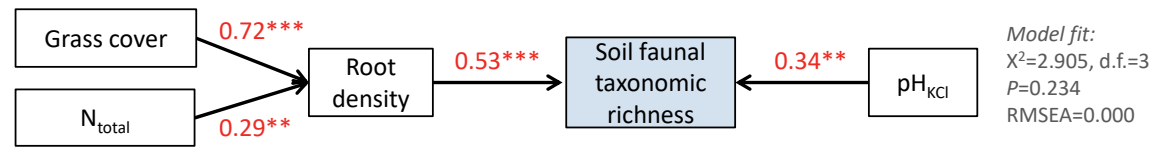

b)

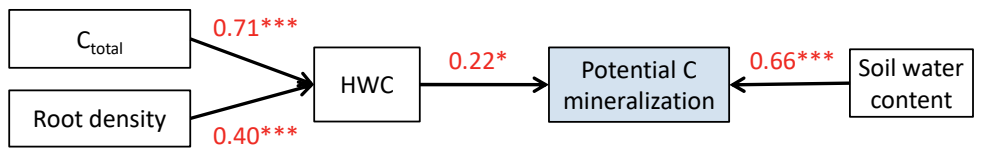

Model fit: $X^{2}=1.114$, d.f. $=3$ $P=0.576$ RMSEA $=0.000$

c)

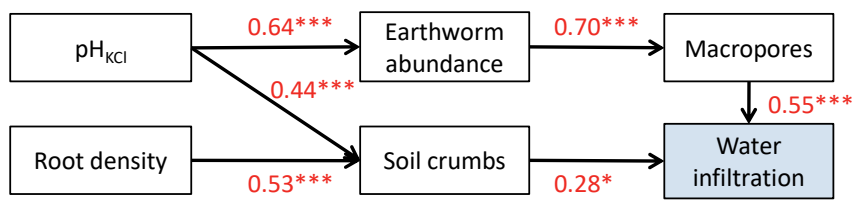

Model fit: $X^{2}=10.002$, d.f. $=8$ $P=0.297$ RMSEA $=0.079$

d)
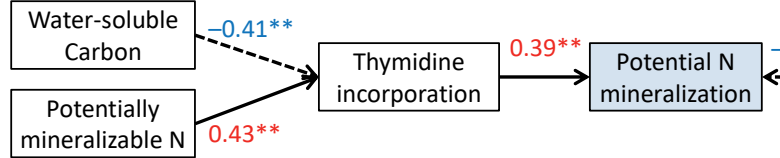
$-0.34^{*}$
$\begin{gathered}\text { Bacterial } \\ \text { mass }\end{gathered}$ mineralizable $\mathrm{N} 0.43 * *$

Figure 2.2 Structural equation models based on data from 40 grasslands on peat for: a) Soil faunal taxonomic richness (combined index), b) Potential C mineralization, c) Water infiltration, d) Potential $\mathrm{N}$ mineralization. Arrows represent significant relationships (continuous: positive; dashed: negative). Numbers next to the arrows are path coefficients (red: positive; blue: negative); stars indicate their significance level $\left({ }^{*} P \leq 0.05 ;{ }^{* *} P \leq 0.01 ;{ }^{* *} P \leq 0.001\right)$. An adequate model fit is indicated by nonsignificant Chi $_{2}$-test $(\mathrm{P}>0.050)$ and low RMSEA $(<0.080)$.

\subsection{Discussion and conclusions}

\subsubsection{Ecosystem service maintenance of biodiversity}

The average abundance and taxonomic richness of soil biota were higher in dairy grasslands, but the gamma diversity in this land use was lower than in semi-natural grasslands (Fig. 2.1). Our hypothesis did not include this effect of scale and had therefore to be partly rejected.

At the scale of grassland, the variation in soil faunal taxonomic richness between sites was explained by soil pH and root density (Fig. 2.2a). Taxonomic richness correlated 
positively with soil crumbliness and nutrient concentrations. A positive influence of nutrient levels is in line with studies of grasslands on sand and clay soils (Mulder and Elser, 2009; Van der Wal et al., 2009). Within the individual groups - particularly nematodes, earthworms and microarthropods - trophic or life stage distributions confirm an overall positive sensitivity to nutrient levels, $\mathrm{pH}$, input of young organic matter and soil temperature. First, the higher nematode counts in dairy grasslands were due to a higher number and proportion of bacterial feeders, correlating with soil fertility parameters such as $\mathrm{pH}, \mathrm{P}_{\mathrm{AL}}$ and nitrate concentrations $(\mathrm{r}=0.69,0.60$ and 0.65 , respectively; $P<0.001)$. This may be explained by a higher input of easily decomposable organic matter to the soil via manure and primary production (plant residues, root exudates) in dairy grasslands (Biederman et al., 2008; Yeates, 1987). Second, the abundance of earthworms, particularly of juveniles, was higher in dairy grasslands. This is likely to be related to the combination of higher soil pH (Curry, 2004), higher input of organic matter via primary production and manure (Bouché, 1977; Hansen and Engelstad, 1999) and drier (thus also warmer) soil conditions during the winter season (Plum and Filser, 2005; Timmerman et al., 2006) in those grasslands. Especially the higher proportion of juveniles in dairy grasslands (sampled in April) indicate more favorable soil conditions: earthworm densities increase when overwintered cocoons start to hatch at increasing temperature in spring (Edwards and Bohlen, 1996). Lastly, the higher numbers of microarthropods in dairy grasslands with more predators and less herbivores indicate a more dynamic environment and a richer diet. Within grassland systems, different studies showed increased microarthropod densities with improved soil fertility and plant productivity (Cole et al., 2005; King and Hutchinson, 1980). Thus, in our case, well-drained and well-structured dairy grassland soils supported a more abundant and diverse community of soil biota than semi-natural grassland soils due to higher root density, $\mathrm{pH}$, nutrient input and probably also higher soil temperatures in winter and spring.

In contrast to the above, the diversity across sampling sites (gamma diversity) was lower in dairy grasslands (Fig. 2.1). This indicates that the botanical and soil faunal taxonomic composition was quite homogenous across dairy grasslands, and more diverse across semi-natural grasslands. This could well be related to a lower diversity in land management across dairy grasslands, as reflected in lower standard deviations in most abiotic soil parameters (Tables 2.1 and 2.4). These findings have implications for nature conservation in managed peat areas at field and landscape scale. First, the trend in modern 
agriculture towards low inter-farm diversity (Swift et al., 2004) should be reversed to promote diversification of agroecosystems and nature-inclusive agriculture (Erisman et al., 2016). Second, the lower soil faunal diversity of individual semi-natural grasslands may imply that with the current management, many (semi-)natural grasslands are needed to increase the total nature value. Finally, our results emphasize the importance of considering the spatial scale when evaluating ecological observations (Ettema and Wardle, 2002).

In relation to the ecosystem service maintenance of biodiversity, we conclude that soil faunal abundance and diversity were greater in dairy grasslands due to higher input of fresh, nutrient-rich organic matter and drier soil conditions in spring. However, the gamma diversity (at land use scale) was lower in dairy grasslands due to a lower inter-farm diversity.

\subsubsection{Ecosystem service climate regulation: $\mathrm{CO}_{2}$ emission}

Potential C mineralization is a measure of the decomposition of organic matter by heterotrophic microorganisms in soil (Haynes, 2005). Our $\mathrm{CO}_{2}$ measurements during 6week laboratory incubations of field moist soil therefore indicated field $\mathrm{C}$ mineralization and $\mathrm{CO}_{2}$ emission.

Contrary to our hypothesis, the results do not indicate differences in potential $\mathrm{C}$ mineralization or in microbial activity between dairy and semi-natural grassland soils. However, other soil properties that may influence the $\mathrm{C}$ mineralization rates such as soil water content, HWC (a labile C pool) and pH (Ghani et al., 2003; Wang et al., 2003) were influenced by grassland type. The SEM model explaining potential $\mathrm{C}$ mineralization showed a combined dependence on HWC and soil water content (Fig. 2.2b). Surprisingly, the effect of soil moisture was positive, indicating that mineralization may have been limited by dry topsoil in the dairy grasslands, compared to the wetter semi-natural grasslands. Semi-natural grassland soils were wetter but still had sufficient soil air volume (>10\%) for aerobic processes (Da Silva et al., 1994). There is evidence that in peat grasslands, soil respiration can be limited by the lack of air at high soil water levels, but also by drought in situations of deep drainage (Berglund and Berglund, 2011).

Although potential C mineralization was similar in both grassland types, correlations with other soil parameters in the separate subsets show interesting differences. In both 
cases, the limitation by drought was dominant (Table S2.4). In dairy grasslands, potential $\mathrm{C}$ mineralization was also correlated with HWC and clay percentage. HWC itself correlated with $\mathrm{C}_{\text {total, }} \mathrm{N}_{\text {total, }}$, potentially mineralizable $\mathrm{N}$ and root density (Table S2.5). Therefore, in dairy grasslands, the mineralized $\mathrm{C}$ seemed to originate principally from a pool of labile organic substrate (reflected by HWC) from relatively young organic matter: livestock manure, grass residues and rhizodeposition (Ghani et al., 2003; Haynes, 2005). In seminatural grasslands, however, a strong correlation of potential C mineralization was found with WSC and microbial biomass. WSC is a labile C fraction in soil that consists of both relatively resistant humic acids formed by microbial degradation, and readily degradable carbohydrates which are key substrates for microbial activity (Haynes, 2005). Being partly a substrate for potential C mineralization, the WSC pool in semi-natural grasslands was relatively small (Tables 2.2 and 2.4: only c. twice the amount of the $\mathrm{C}$ mineralized per week). The positive correlation therefore indicates that WSC was limiting C mineralization. In this situation, a fast replenishment of the WSC pool has to be realized by microbial activity and physical-chemical processes producing WSC from soil $\mathrm{C}_{\text {total }}$ and plant residues (Haynes, 2005). In our data set, WSC indeed correlated positively with soil water content, fungal biomass and $\mathrm{C}_{\text {total }}$ (Table S2.5). Thus, in semi-natural grasslands, potential C mineralization appeared to be determined by highly degradable organic substrate (WSC), which in turn was dependent on soil fungi and soil water for replenishment from $\mathrm{C}_{\text {total }}$. Finally, the higher nematode enrichment index in dairy grasslands and the higher nematode channel index in semi-natural grasslands support the observation that $C$ mineralization was more bacterial driven in dairy grasslands and more fungal driven in semi-natural grasslands (Ferris et al., 2001).

Our measurements were carried out in grassland types differing in drainage intensity. The lack of difference in potential $\mathrm{C}$ mineralization is surprising, because drainage and an oxic topsoil is seen as the main reason for progressive peat decomposition (KasimirKlemedtsson et al., 1997; Kluge et al., 2008; Krüger et al., 2015; Schothorst, 1977). However, we measured the microbial parameters in the 0-10 cm layer only, in line with standard methods for ecological research in grassland soils (Bloem et al., 2006; Rutgers et al., 2009; Stone et al., 2016; Van Eekeren et al., 2010). Although $\mathrm{CO}_{2}$ release in peat soils typically decreases with depth (Kluge et al., 2008), C mineralization can rapidly increase following exposure of the anaerobic subsoil to oxic conditions (Brouns et al., 2014; Chow 
et al., 2006). Potential $\mathrm{C}$ mineralization in samples from the topsoil is not indicative of $\mathrm{CO}_{2}$ release from deep peat soils, especially with fluctuating groundwater level.

In relation to the ecosystem service climate regulation, we conclude that the rate of $\mathrm{C}$ mineralization in the topsoil was not influenced by land management, but was limited by drought in both dairy and semi-natural grasslands. In addition, $\mathrm{C}$ mineralization seemed to involve different $\mathrm{C}$ sources and microbial groups per grassland type: in dairy grasslands, potential C mineralization correlated with HWC originating from relatively young organic matter, whereas in semi-natural grasslands it correlated with WSC, which was dependent on soil fungi and soil water for replenishment from $\mathrm{C}_{\text {total }}$.

\subsubsection{Ecosystem service water regulation: water infiltration}

Our measurements do not support the hypothesis that dairy grasslands have low water infiltration rates due to inferior soil structure caused by farming activities. On the contrary, dairy grasslands were drier and had a higher percentage of crumb structures, more macropores, more roots and a higher water infiltration rate than semi-natural grasslands. The lower soil moisture content is probably a direct effect of more intensive drainage combined with higher evapotranspiration in more productive grasslands, and also explains the higher load bearing capacity and penetration resistance (Schothorst, 1982). Water infiltration appeared to be determined by soil macroporosity and crumbliness, and indirectly by parameters related to biological activity (earthworm abundance, root density) and pH (Fig. 2.2c). Root density was linked with percentage of grass cover and soil $\mathrm{N}_{\text {total. }}$. Causalities between these parameters are well documented, partly also for peat soils (Bouché and Al-Addan, 1997; Curry, 2004; Dettmann et al., 2014; Holden, 2005; Van Eekeren et al., 2009b). The differences in soil structure, soil biota, root density and $\mathrm{pH}$ between dairy and semi-natural grasslands are therefore clear explanations for the different water infiltration rates.

In view of future climate change scenarios (KNMI, 2014), the water infiltration capacity of soils is important for flood prevention, because water storage in the soil reduces peak loads of drainage water in ditches and rivers. Our results show that the soil properties of semi-natural grasslands lead to a limited water infiltration rate compared to dairy grasslands, and that these soil properties are inherently linked with the management of these grasslands: high water levels and low organic matter inputs resulting in low soil 
biological activity. Ways to improve water infiltration capacity in semi-natural grasslands (i.e. control of soil acidity, more manure for earthworms and higher grass cover for root density) are therefore limited and may compromise the primary land use and management objectives of these areas.

In relation to the ecosystem service water regulation, we conclude that soil biological activity, including plant roots, plays a key role. In semi-natural grasslands, the biological activity and water infiltration rates were lower than in dairy grasslands.

\subsubsection{Ecosystem service grass production: soil fertility}

The contribution of the peat soil to the ecosystem service grass production was assessed from abiotic ( $\mathrm{pH}$, nutrient concentrations, soil structure) and biotic soil parameters (potential N mineralization) (Haynes, 2005; Van Eekeren et al., 2010). As expected, dairy grassland soils had higher $\mathrm{pH}$ and higher concentrations of plant available nutrients than semi-natural grasslands. However, contrary to our hypothesis, the potential $\mathrm{N}$ mineralization, an indicator of the ability of soils to supply crops with mineral $\mathrm{N}$ (Haynes, 2005), was similar in both grassland types.

The higher $\mathrm{pH}$ in dairy grasslands may be the result of differences in $\mathrm{H}^{+}$production (cation uptake by plants, SOM accumulation) and consumption (decomposition and mineralization of SOM) (Bolan and Hedley, 2003; De Klein et al., 1997). Moreover, pH may have been influenced by liming in the past as part of standard practice. Similarly, the observed differences in soil $\mathrm{P}$ and $\mathrm{N}$ between grassland types (Table 2.4) can be attributed to contrasting management types. It is known that $P$ accumulates in dairy systems due to long term use of animal manure because of its relatively high P:N ratio (Whalen and Chang, 2001). In addition to higher $\mathrm{pH}$ and nutrient availability, dairy grassland soils were more crumbly and had higher root densities than semi-natural grassland soils, presumably due to a combination of drier conditions during winter, higher biological activity and a higher grass cover.

Potential N mineralization did not significantly differ between grassland types and was three times higher than in grasslands on sandy soils (Van Eekeren et al., 2009a). These high values can be explained by the high SOM, $\mathrm{N}_{\text {total }}$ and potentially mineralizable $\mathrm{N}$ contents of peat soils. The ratio of potentially mineralizable $\mathrm{N}$ to potential $\mathrm{N}$ mineralization in peat (10-15) was higher than in sandy soils (7). On peat, the differences in potentially 
mineralizable $\mathrm{N}$ between dairy and semi-natural grasslands did not result in diverging potential $\mathrm{N}$ mineralization rates. Apparently, the amount of mineralizable $\mathrm{N}$ did not limit mineralization rate. Potential $\mathrm{N}$ mineralization is the net result of 'gross' mineralization of labile $\mathrm{N}$ minus $\mathrm{N}$ immobilization into microbial biomass and $\mathrm{N}$ loss by denitrification (Haynes, 2005; Hodge et al., 2000). In the SEM, potential N mineralization was positively correlated with bacterial growth measured by thymidine incorporation, and negatively with bacterial biomass (Fig. 2.2d). In this model, bacterial growth can be a reflection of the 'gross' $\mathrm{N}$ mineralization, and bacterial biomass a reflection of $\mathrm{N}$ immobilization. Microbial activity and $\mathrm{N}$ mineralization are positively influenced by microbivores such as protozoa and nematodes (Bloem et al., 1994; Bouwman et al., 1994). In our data, however, there was no significant correlation between thymidine incorporation and bacterivorous nematodes. Instead, thymidine incorporation was determined by WSC (negative correlation) and potentially mineralizable $\mathrm{N}$ (positive correlation) (Fig. 2.2d). Substitution of WSC and potentially mineralizable $\mathrm{N}$ by soil $\mathrm{C}: \mathrm{N}$ ratio in this model did not lead to a significant fit, which indicates sensitivity of bacterial growth to the labile fractions rather than to the total pools of soil $\mathrm{C}$ and $\mathrm{N}$. The importance of $\mathrm{N}$ immobilization in our peat soils is indicated by i) the negative correlation of microbial biomass and potential $\mathrm{N}$ mineralization (Fig. 2.2d), ii) the lack of direct correlation between the amount of mineralizable $\mathrm{N}$ and $\mathrm{N}$ mineralization (Fig. 2.2d) and iii) the absence of correlation between potential $\mathrm{N}$ mineralization and potential C mineralization $(r=0.02)$ (Haynes, 2005).

Concerning the ecosystem service grass production, we conclude that dairy grasslands had higher $\mathrm{pH}$, nutrient concentrations and better soil structure, as expected. However, potential $\mathrm{N}$ mineralization rate was not affected by land management but was controlled by variation in bacterial biomass apparently indicating $\mathrm{N}$ immobilization, and by bacterial growth that depended on the amounts of labile $\mathrm{C}$ and $\mathrm{N}$ in soil.

\subsection{Perspectives and recommendations}

Drained peat soils worldwide contribute $6 \%$ to the anthropogenic $\mathrm{CO}_{2}$ emission, which is disproportional to their relatively small surface (0.3\% of the land area) (Joosten, 2011). Although $\mathrm{CO}_{2}$ emission and contribution to climate change are the major concerns for these soils, we examined effects of land use in a broader context, including maintenance of biodiversity, water regulation and potential for agricultural production. Our study 
results in the following recommendations for land use policy and land management of peat grasslands:

Biodiversity - Spatial scale is of crucial importance in maintaining biodiversity and considering biodiversity management strategies. Especially in dairy grasslands, diversification in management between sites and farms may increase biodiversity at larger geographical scale. Similarly, diversity in types and management of (semi-)natural grasslands is needed to keep a high above and belowground biodiversity at landscape scale. Diversification may be found in drainage management, type of vegetation, nutrient management and use of grazing livestock.

Climate regulation - For dairy grasslands, management should focus on sufficient input of organic matter to compensate for topsoil decomposition, and on minimal peat decomposition in subsoil, for example by water management with submerged tile drains. For semi-natural grasslands, management should focus on reducing peat decomposition by raising groundwater levels, and on stimulating $C$ accumulation in the soil. This may imply changes in vegetation type and can negatively affect biodiversity conservation objectives, for example concerning meadow birds.

Water regulation - Management of dairy grasslands should focus on maintaining a high water regulation capacity by sustaining soil biological activity (earthworms, rooting) through sufficient organic matter input and control of soil $\mathrm{pH}$. In semi-natural grasslands, however, options to improve water infiltration (i.e. increasing soil biological activity with organic matter input, control of soil $\mathrm{pH}$ and drainage during the wet season) are limited. Water regulation strategies in these areas should therefore be based on fluctuating (and high) surface water levels and appropriate vegetation types.

Grass production - N supply from soil to grass appears to depend mainly on mineralization of young organic matter. Input of organic $N$ to the soil (crop residues, manure) should therefore be equal to net mineralization.

\section{Acknowledgements}

The authors thank Marleen Zanen, Wim Dijkman, Gerard Jagers op Akkerhuis, Frank Lenssinck, Ton Schouten and Sjoerd Smits for their contributions to the project. Gerben Bakker, Jaap Bogte, Popko Bolhuis, Riekje Bruinenberg, Henri den Hollander, Wim Dimmers, Hans Dullaert, René Groenen, Tamás Salánki, Erik Steenbergen, Karel van 
Houwelingen, Eef Velthorst, Meint Veningat and An Vos are acknowledged for their technical assistance. We are grateful to Edith Lammerts van Bueren and three anonymous reviewers who helped to improve the manuscript.

\section{Funding}

This work was funded by Stichting Kennisontwikkeling en Kennisoverdracht Bodem, the Provinces Noord-Holland, Zuid-Holland and Utrecht and Interdepartementaal Programma Biodiversiteit. Access to data from the Netherlands Soil Quality Monitoring Network was supported by the Ministry of Infrastructure and Environment within the RIVM project BEO (M/607406). Jaap Bloem was supported by the research program KB 21 "Sustainable Food and non-Food production" funded by the Netherlands Ministry of Economic Affairs. 


\section{Appendix: Supplementary Material}

Table S2.1 (extension of Table 2.1) Plant species ${ }^{\dagger}$ (means, standard deviations, $P$-values) of dairy ( $\mathrm{n}=$ $20)$ and semi-natural $(n=20)$ grasslands on peat. Only data on plant species with an average $D+N$ score $\geq 1.0$ are presented.

\begin{tabular}{|c|c|c|c|c|c|}
\hline \multirow[b]{2}{*}{ Parameter } & \multicolumn{2}{|l|}{ Dairy } & \multicolumn{2}{|c|}{ Semi-natural } & \multirow[t]{2}{*}{$P$-value ${ }^{\ddagger}$} \\
\hline & mean & s.d. & mean & s.d. & \\
\hline Lolium perenne & 7.4 & 0.7 & 3.8 & 3.2 & $<0.001$ \\
\hline Poa trivialis & 5.8 & 1.1 & 4.4 & 2.3 & 0.018 \\
\hline Poa pratensis & 3.7 & 1.5 & 1.9 & 2.5 & 0.008 \\
\hline Trifolium repens & 3.1 & 2.2 & 1.8 & 2.1 & 0.064 \\
\hline Agrostis stolonifera & 2.9 & 2.5 & 1.8 & 2.2 & 0.151 \\
\hline Elytrigia repens & 2.8 & 2.4 & 0.3 & 0.9 & $<0.001$ \\
\hline Holcus lanatus & 2.4 & 1.8 & 3.3 & 2.4 & 0.195 \\
\hline Stellaria media & 2.3 & 1.2 & 0.2 & 0.6 & $<0.001$ \\
\hline Ranunculus repens & 2.3 & 1.7 & 4.6 & 2.6 & 0.002 \\
\hline Taraxacum species & 2.2 & 1.3 & 1.2 & 1.4 & 0.033 \\
\hline Alopecurus pratensis & 1.7 & 2.3 & 2.7 & 2.5 & 0.212 \\
\hline Alopecurus geniculatus & 1.5 & 1.8 & 2.5 & 2.0 & 0.121 \\
\hline Glyceria fluitans & 1.0 & 1.7 & 2.4 & 2.7 & 0.053 \\
\hline Rumex acetosa & 0.9 & 1.2 & 2.2 & 2.1 & 0.020 \\
\hline Cardamine pratensis & 0.5 & 0.9 & 1.5 & 1.5 & 0.016 \\
\hline Bromus hordeaceus s. hord. & 0.3 & 1.1 & 1.7 & 2.0 & 0.009 \\
\hline Cerastium fontanum s. vulgare & 0.0 & 0.0 & 2.0 & 1.5 & $<0.001$ \\
\hline Juncus effusus & 0.0 & 0.0 & 1.4 & 2.2 & 0.008 \\
\hline
\end{tabular}

${ }^{\dagger}$ Braun-Blanquet cover-abundance alpha-numerical scores were replaced with a fully numerical 1-9 scale.

${ }^{\ddagger}$ maximum $P$-values for differences after correction for number of parameters (see Methods): 0.024 at $\alpha=5 \%$ (significant difference, bold); 0.056 at $\alpha=10 \%$ (trend, italic). 
Table S2.2 (extension of Table 2.3) Soil biotic parameters (means, standard deviations, $P$-values) dairy $(n=20)$ and semi-natural $(n=20)$ grasslands on peat.

\begin{tabular}{|c|c|c|c|c|c|c|}
\hline \multirow[b]{2}{*}{ Parameter } & \multirow[b]{2}{*}{ Unit } & \multicolumn{2}{|l|}{ Dairy } & \multicolumn{2}{|c|}{ Semi-natural } & \multirow[t]{2}{*}{$P$-value ${ }^{\dagger}$} \\
\hline & & mean & s.d. & mean & s.d. & \\
\hline \multicolumn{7}{|l|}{ Combined soil faunal scores } \\
\hline Total number of taxa & $\mathrm{n}$ taxa & 71 & 4 & 61 & 12 & $<0.001$ \\
\hline Combined taxonomic index & - & 0.29 & 0.30 & -0.29 & 0.76 & 0.003 \\
\hline Combined abundance index & - & 0.24 & 0.38 & -0.24 & 0.54 & 0.002 \\
\hline \multicolumn{7}{|l|}{ Nematodes } \\
\hline Abundance & n. $100 \mathrm{~g}^{-1}$ & 8597 & 2267 & 6221 & 2803 & 0.005 \\
\hline Taxonomic richness & $\mathrm{n}$ taxa & 31.2 & 2.8 & 24.7 & 6.1 & $<0.001$ \\
\hline Diversity index & - & 2.9 & 0.2 & 2.5 & 0.4 & $<0.001$ \\
\hline Maturity index & - & 2.20 & 0.18 & 2.29 & 0.24 & 0.186 \\
\hline Structure index & $\%$ & 54.5 & 9.7 & 50.6 & 19.3 & 0.430 \\
\hline Enrichment index & $\%$ & 52.1 & 15.8 & 39.6 & 15.5 & 0.016 \\
\hline Channel index & $\%$ & 8.1 & 8.5 & 26.6 & 29.4 & 0.046 \\
\hline Herbivores & $\mathrm{n} .100 \mathrm{~g}^{-1}$ & 4505 & 2322 & 4129 & 2147 & 0.598 \\
\hline Fungivores & n. $100 \mathrm{~g}^{-1}$ & 161 & 74 & 137 & 88 & 0.347 \\
\hline Bacterivores & n. $100 \mathrm{~g}^{-1}$ & 3249 & 931 & 1632 & 1081 & $<0.001$ \\
\hline Predators & n. $100 \mathrm{~g}^{-1}$ & 289 & 150 & 130 & 136 & 0.001 \\
\hline Omnivores & n. $100 \mathrm{~g}^{-1}$ & 426 & 222 & 228 & 199 & 0.005 \\
\hline Herbivores & $\%$ & 50.3 & 14.5 & 63.2 & 14.4 & 0.008 \\
\hline Fungivores & $\%$ & 2.0 & 0.9 & 4.1 & 5.5 & 0.093 \\
\hline Bacterivores & $\%$ & 39.6 & 12.4 & 26.3 & 9.7 & $<0.001$ \\
\hline Predators & $\%$ & 3.5 & 2.2 & 1.9 & 1.5 & 0.011 \\
\hline Omnivores & $\%$ & 5.1 & 2.4 & 5.1 & 6.2 & 1.000 \\
\hline \multicolumn{7}{|l|}{ Enchytraeids } \\
\hline Abundance & $\mathrm{n} \mathrm{m}^{-2}$ & 31642 & 9967 & 37354 & 10841 & 0.091 \\
\hline Biomass & $\mathrm{g} \mathrm{m}^{-2}$ & 13.5 & 5.6 & 9.9 & 6.2 & 0.062 \\
\hline Mean body weight & $m g$ ind $^{-1}$ & 0.44 & 0.15 & 0.26 & 0.14 & $<0.001$ \\
\hline Taxonomic richness & $\mathrm{n}$ taxa & 10.3 & 2.1 & 7.9 & 3.0 & 0.007 \\
\hline Diversity index & - & 2.0 & 0.3 & 1.5 & 0.6 & 0.003 \\
\hline Fridericia & $\mathrm{n} \mathrm{m}^{-2}$ & 15267 & 7778 & 9207 & 7554 & 0.017 \\
\hline Marionina & $\mathrm{n} \mathrm{m}^{-2}$ & 11589 & 7106 & 17678 & 11246 & 0.048 \\
\hline Enchytraeus & $\mathrm{n} \mathrm{m}^{-2}$ & 4786 & 5152 & 10404 & 13158 & 0.083 \\
\hline Fridericia & $\%$ & 48.1 & 18.6 & 25.5 & 19.1 & $<0.001$ \\
\hline Marionina & $\%$ & 36.3 & 18.4 & 47.0 & 24.7 & 0.129 \\
\hline Enchytraeus & $\%$ & 15.6 & 15.4 & 27.5 & 29.6 & 0.119 \\
\hline Fridericia & $\mathrm{g} \mathrm{m}^{-2}$ & 11.1 & 5.8 & 6.0 & 7.0 & 0.017 \\
\hline Marionina & $\mathrm{g} \mathrm{m}^{-2}$ & 1.89 & 1.08 & 2.18 & 1.68 & 0.526 \\
\hline Enchytraeus & $\mathrm{g} \mathrm{m}^{-2}$ & 0.55 & 0.75 & 1.70 & 2.47 & 0.053 \\
\hline \multicolumn{7}{|l|}{ Earthworms } \\
\hline Abundance & $\mathrm{n} \mathrm{m}^{-2}$ & 587 & 318 & 270 & 247 & 0.001 \\
\hline Biomass & $\mathrm{g} \mathrm{m}^{-2}$ & 146 & 77 & 75 & 64 & 0.003 \\
\hline Mean body weight & $\mathrm{g} \mathrm{ind}^{-1}$ & 0.26 & 0.08 & 0.31 & 0.12 & 0.170 \\
\hline Taxonomic richness & $\mathrm{n}$ taxa & 5.4 & 1.9 & 5.9 & 2.9 & 0.598 \\
\hline Diversity index & - & 1.2 & 0.3 & 0.9 & 0.5 & 0.098 \\
\hline
\end{tabular}




\begin{tabular}{|c|c|c|c|c|c|c|}
\hline \multirow[b]{2}{*}{ Parameter } & \multirow[b]{2}{*}{ Unit } & \multicolumn{2}{|l|}{ Dairy } & \multicolumn{2}{|c|}{ Semi-natural } & \multirow[t]{2}{*}{$P$-value ${ }^{\dagger}$} \\
\hline & & mean & s.d. & mean & s.d. & \\
\hline Adults & $\mathrm{n} \mathrm{m}^{-2}$ & 211 & 139 & 111 & 101 & 0.008 \\
\hline Juveniles & $\mathrm{n} \mathrm{m}^{-2}$ & 311 & 191 & 129 & 153 & $<0.001$ \\
\hline Adults & $\%$ & 36.4 & 13.7 & 45.7 & 23.8 & 0.138 \\
\hline Juveniles & $\%$ & 53.4 & 14.3 & 35.5 & 24.3 & 0.007 \\
\hline n.d..$^{\ddagger}$ & $\%$ & 10.2 & 5.5 & 18.8 & 25.5 & 0.151 \\
\hline Epigeic & $\mathrm{n} \mathrm{m}^{-2}$ & 192 & 97 & 97 & 91 & 0.003 \\
\hline Endogeic & $\mathrm{n} \mathrm{m}^{-2}$ & 391 & 262 & 170 & 169 & 0.003 \\
\hline Epigeic & $\%$ & 35.5 & 12.5 & 44.6 & 29.8 & 0.220 \\
\hline Endogeic & $\%$ & 64.5 & 12.5 & 55.4 & 29.8 & 0.220 \\
\hline \multicolumn{7}{|l|}{ Microarthropods } \\
\hline Abundance & $\mathrm{n} \mathrm{m}^{-2}$ & 81157 & 33830 & 42944 & 33282 & $<0.001$ \\
\hline Abundance of mites & $\mathrm{n} \mathrm{m}^{-2}$ & 47943 & 27840 & 25558 & 27138 & 0.001 \\
\hline Abundance of collembola & $\mathrm{n} \mathrm{m}^{-2}$ & 33214 & 13449 & 17386 & 13695 & $<0.001$ \\
\hline Taxonomic richness & $\mathrm{n}$ taxa & 24.7 & 3.0 & 22.6 & 4.5 & 0.092 \\
\hline Diversity index & - & 2.7 & 0.2 & 2.6 & 0.3 & 0.309 \\
\hline Mite taxa & $\mathrm{N}$ & 16.3 & 2.9 & 14.6 & 4.0 & 0.129 \\
\hline Collembola taxa & $\mathrm{N}$ & 8.4 & 1.7 & 8.0 & 2.5 & 0.557 \\
\hline Arthropod predator & $\mathrm{n} \mathrm{m}^{-2}$ & 327 & 487 & 444 & 551 & 0.482 \\
\hline Bacteriovorous & $\mathrm{n} \mathrm{m}^{-2}$ & 1610 & 2637 & 189 & 467 & 0.023 \\
\hline Fungivorous browser & $\mathrm{n} \mathrm{m}^{-2}$ & 31520 & 12805 & 15586 & 13640 & $<0.001$ \\
\hline Fungivorous grazer & $\mathrm{n} \mathrm{m}^{-2}$ & 19779 & 16205 & 6939 & 11838 & 0.007 \\
\hline General predator & $\mathrm{n} \mathrm{m}^{-2}$ & 8433 & 6078 & 3637 & 3037 & 0.005 \\
\hline Herbivorous browser & $\mathrm{n} \mathrm{m}^{-2}$ & 3341 & 2971 & 1045 & 1068 & 0.010 \\
\hline Herbivorous grazer & $\mathrm{n} \mathrm{m}^{-2}$ & 6469 & 5613 & 7358 & 4944 & 0.310 \\
\hline Nematode predator & $\mathrm{n} \mathrm{m}^{-2}$ & 1244 & 1764 & 407 & 1117 & 0.081 \\
\hline Omnivorous & $\mathrm{n} \mathrm{m}^{-2}$ & 1726 & 1340 & 3842 & 5256 & 0.089 \\
\hline Opport. herbofungivorous & $\mathrm{n} \mathrm{m}^{-2}$ & 6584 & 8404 & 2743 & 6509 & 0.114 \\
\hline Arthropod predator & $\%$ & 0.5 & 0.6 & 1.1 & 1.1 & 0.024 \\
\hline Bacteriovorous & $\%$ & 2.2 & 3.2 & 0.6 & 1.2 & 0.046 \\
\hline Fungivorous browser & $\%$ & 40.2 & 11.3 & 34.9 & 16.6 & 0.247 \\
\hline Fungivorous grazer & $\%$ & 21.9 & 14.0 & 12.1 & 11.8 & 0.022 \\
\hline General predator & $\%$ & 10.2 & 4.4 & 8.0 & 5.9 & 0.194 \\
\hline Herbivorous browser & $\%$ & 3.9 & 3.0 & 2.5 & 2.4 & 0.098 \\
\hline Herbivorous grazer & $\%$ & 9.7 & 9.9 & 23.6 & 16.5 & $<0.001$ \\
\hline Nematode predator & $\%$ & 1.5 & 2.1 & 0.6 & 1.1 & 0.099 \\
\hline Omnivorous & $\%$ & 2.3 & 1.8 & 10.3 & 13.3 & $<0.001$ \\
\hline Opport. herbofungivorous & $\%$ & 7.7 & 8.5 & 4.1 & 6.3 & 0.142 \\
\hline
\end{tabular}

${ }^{+}$maximum $P$-values for differences after correction for number of parameters (see Methods): 0.024 at $\alpha=5 \%$ (significant difference, bold); 0.056 at $\alpha=10 \%$ (trend, italic).

${ }^{\ddagger}$ n.d.: counted and classified in functional group (epigeic or endogeic), but no possible classification in life stage (adult or juvenile) or determination to species level. 
Table S2.3 (extension of Table 2.4) Soil abiotic parameters (means, standard deviations, $P$-values) of dairy $(n=20)$ and semi-natural $(n=20)$ grasslands on peat.

\begin{tabular}{|c|c|c|c|c|c|c|}
\hline \multirow[b]{2}{*}{ Parameter } & \multirow[b]{2}{*}{ Unit } & \multicolumn{2}{|l|}{ Dairy } & \multicolumn{2}{|c|}{ Semi-natural } & \multirow[t]{2}{*}{$P$-value ${ }^{\dagger}$} \\
\hline & & mean & s.d. & mean & s.d. & \\
\hline \multicolumn{7}{|l|}{ Soil physical parameters } \\
\hline Penetr. resistance $(0-10 \mathrm{~cm})$ & $\mathrm{N}\left(2 \mathrm{~cm}^{2}\right)$ & 190 & 41 & 169 & 42 & 0.119 \\
\hline Penetr. resistance $(10-20 \mathrm{~cm})$ & $\mathrm{N}\left(2 \mathrm{~cm}^{2}\right)$ & 206 & 43 & 166 & 46 & 0.008 \\
\hline Penetr. resistance $(20-30 \mathrm{~cm})$ & $\mathrm{N}\left(2 \mathrm{~cm}^{2}\right)$ & 176 & 26 & 143 & 43 & 0.005 \\
\hline Load bearing capacity & $\mathrm{N}_{\max }\left(5 \mathrm{~cm}^{2}\right)$ & 553 & 121 & 456 & 120 & 0.015 \\
\hline Sub-angular $(0-10 \mathrm{~cm})$ & $\%$ & 17 & 14 & 52 & 27 & $<0.001$ \\
\hline Angular $(0-10 \mathrm{~cm})$ & $\%$ & 4 & 7 & 2 & 7 & 0.358 \\
\hline Crumbs $(10-20 \mathrm{~cm})$ & $\%$ & 51.2 & 28.4 & 17.7 & 16.6 & $<0.001$ \\
\hline Sub-angular $(10-20 \mathrm{~cm})$ & $\%$ & 26.4 & 39.2 & 9.9 & 22.0 & 0.024 \\
\hline Angular $(10-20 \mathrm{~cm})$ & $\%$ & 22.4 & 32.5 & 18.1 & 23.9 & 0.139 \\
\hline Macropores (20 cm depth) & n. $400 \mathrm{~cm}^{-2}$ & 2.1 & 1.2 & 2.1 & 1.3 & 0.108 \\
\hline Roots (20 cm depth) & n. $400 \mathrm{~cm}^{-2}$ & 139.0 & 97.7 & 68.1 & 64.1 & 0.056 \\
\hline Water content at pF 2 & Vol. \% & 65.0 & 3.2 & 66.9 & 5.0 & 0.165 \\
\hline Air content at $\mathrm{pF} 2$ & Vol. \% & 14.6 & 3.3 & 14.5 & 3.8 & 0.904 \\
\hline Silt $(2-50 \mu \mathrm{m})$ & g.100 g soil ${ }^{-1}$ & 30.4 & 6.0 & 34.7 & 8.3 & 0.070 \\
\hline Sand $(>50 \mu \mathrm{m})$ & g.100 g soil ${ }^{-1}$ & 2.6 & 3.4 & 6.0 & 7.5 & 0.021 \\
\hline \multicolumn{7}{|l|}{ Soil chemical parameters } \\
\hline $\mathrm{C}: \mathrm{N}$ ratio $(0-10 \mathrm{~cm})$ & $\mathrm{g} \mathrm{g}^{-1}$ & 11.2 & 0.7 & 11.7 & 1.1 & 0.089 \\
\hline C:SOM ratio $(0-10 \mathrm{~cm})$ & $\mathrm{g} \mathrm{g}^{-1}$ & 0.51 & 0.02 & 0.52 & 0.03 & 0.645 \\
\hline Nitrate $(0-20 \mathrm{~cm})$ & mg N.100 g soil ${ }^{-1}$ & 30.5 & 13.0 & 15.1 & 10.7 & $<0.001$ \\
\hline $\operatorname{CEC}(0-20 \mathrm{~cm})$ & meq.100 $\mathrm{g} \mathrm{soil}^{-1}$ & 25.1 & 4.1 & 20.7 & 8.0 & 0.035 \\
\hline Ca saturation $(0-20 \mathrm{~cm})$ & $\%$ & 50.0 & 5.5 & 48.4 & 7.8 & 0.444 \\
\hline Mg saturation $(0-20 \mathrm{~cm})$ & $\%$ & 12.9 & 1.9 & 7.5 & 2.8 & $<0.001$ \\
\hline K saturation $(0-20 \mathrm{~cm})$ & $\%$ & 2.0 & 0.9 & 1.1 & 0.4 & $<0.001$ \\
\hline Ca:Mg ratio $(0-20 \mathrm{~cm})$ & - & 3.9 & 0.7 & 7.2 & 2.7 & $<0.001$ \\
\hline
\end{tabular}

${ }^{\dagger}$ maximum $P$-values for differences after correction for number of parameters (see Methods): 0.024 at $\alpha=5 \%$ (significant difference, bold); 0.056 at $\alpha=10 \%$ (trend, italic). 
Table S2.4 Significant Pearson correlations $(r$ ) between Potential $\mathbf{C}$ mineralization and soil parameters in peat meadows for dairy $(n=20)$, semi-natural $(n=20)$ and all $(n=40)$ grasslands on peat.

\begin{tabular}{lccc}
\hline & & Subset & \\
\cline { 2 - 4 } Soil parameter & Dairy + Semi-natural & Dairy & Semi-natural \\
\hline Fungal biomass & $0.58^{* * *}$ & n.s. & $0.78^{* * *}$ \\
Bacterial biomass & $0.33^{*}$ & n.s. & $0.55^{*}$ \\
Field water content & $0.71^{* * *}$ & $0.65^{* * *}$ & $0.83^{* * *}$ \\
Clay & $-0.47^{* *}$ & $-0.62^{* *}$ & n.s. \\
C total & $0.40^{*}$ & $0.52^{*}$ & n.s. \\
Hot water extractable C & $0.37^{*}$ & $0.60^{* *}$ & $0.49^{*}$ \\
Water-soluble C & $0.55^{* * *}$ & n.s. & $0.76^{* * *}$ \\
\hline
\end{tabular}

${ }^{*} P \leq 0.05 ;{ }^{* *} P \leq 0.01 ;{ }^{* * *} P \leq 0.001$

Table S2.5 Significant Pearson correlations $(r ; n=40)$ of HWC and WSC with soil parameters in grasslands on peat.

\begin{tabular}{lcc}
\hline Soil parameter & HWC & WSC \\
\hline Fungal biomass & n.s. & $0.75^{* * *}$ \\
Potentially mineralizable $\mathrm{N}$ & $0.64^{* * *}$ & n.s. \\
Field water content & n.s. & $0.76^{* * *}$ \\
Root density & $0.45^{* *}$ & n.s. \\
Ctotal & $0.74^{* * *}$ & $0.45^{* *}$ \\
Ntotal & $0.80^{* * *}$ & n.s. \\
\hline
\end{tabular}

$* P \leq 0.05 ; * * P \leq 0.01 ; * * * \leq 0.001$ 


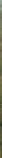

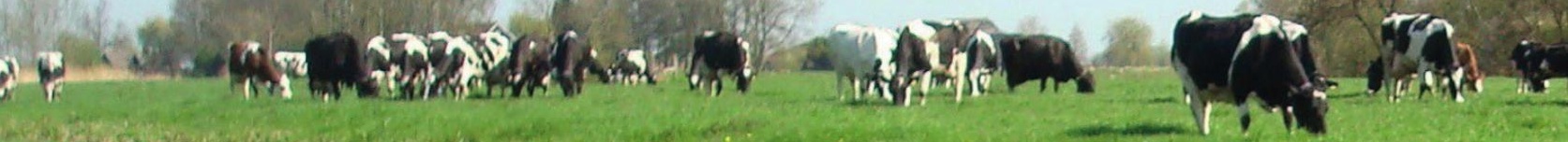

\section{$\sin$}

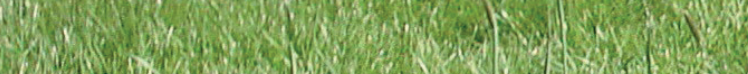

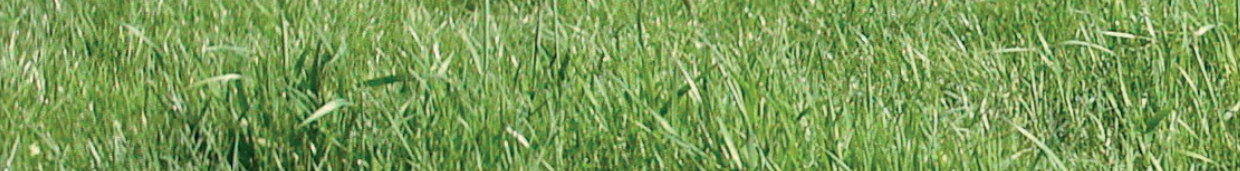

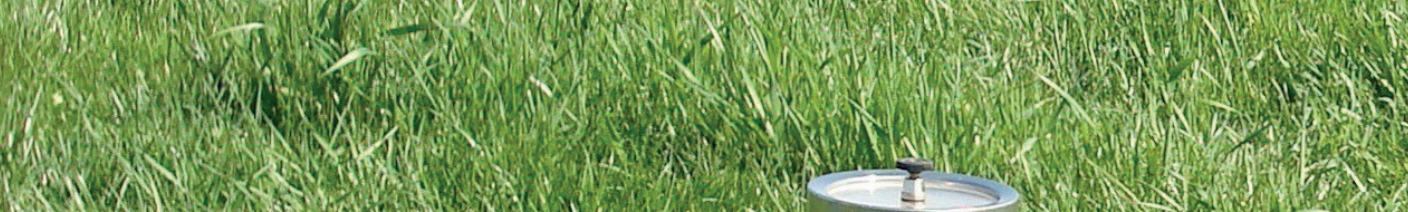

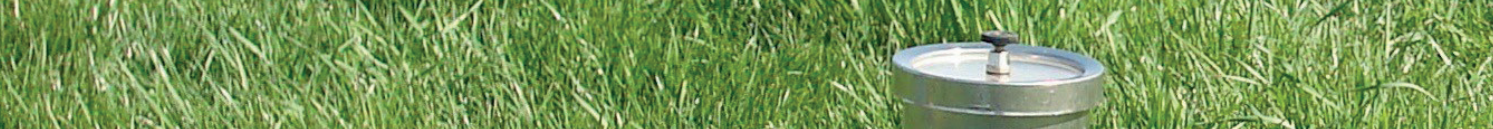
wh.

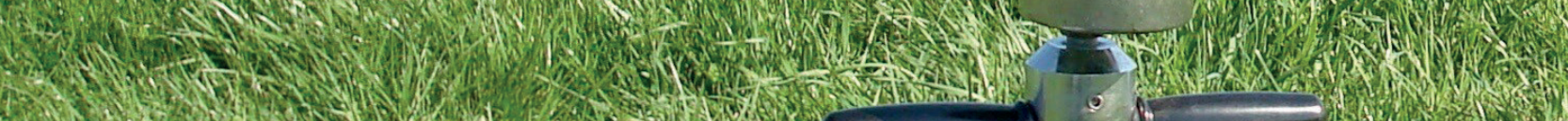

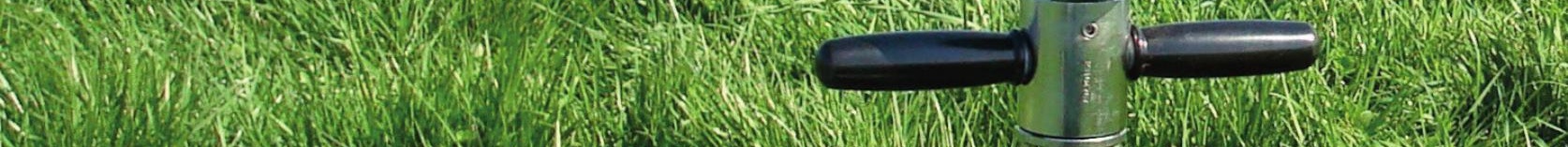
2.t.

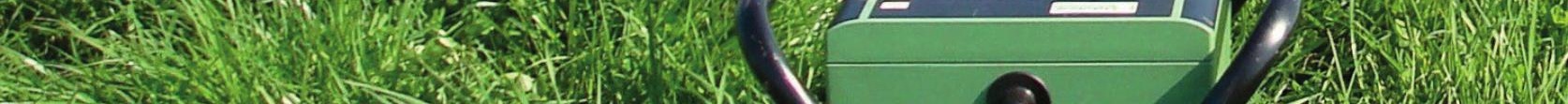

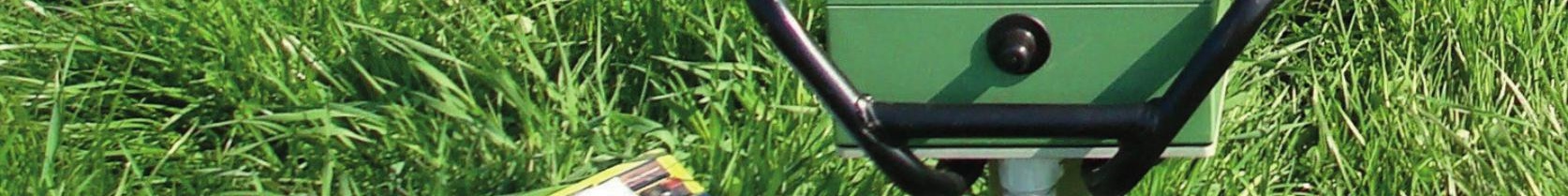

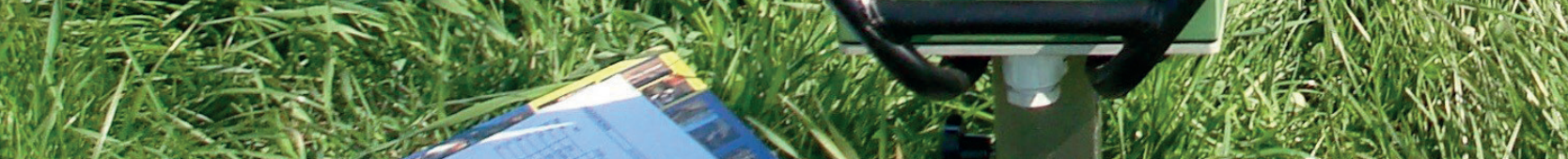

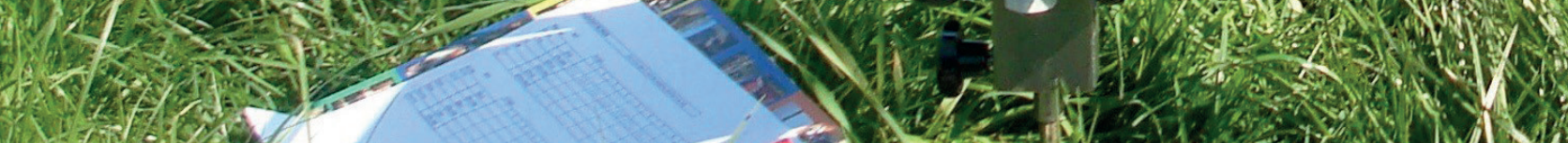

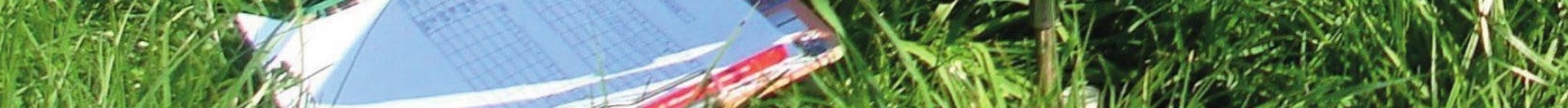
1

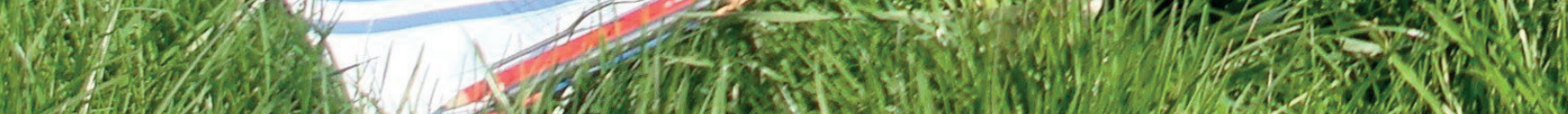
7.

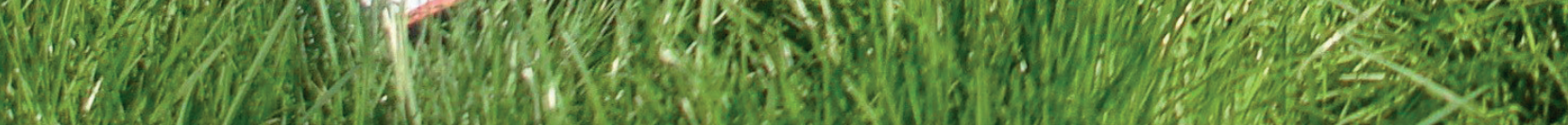




\section{Chapter 3}

\section{Predicting soil $\mathbf{N}$ supply and yield parameters in peat grasslands}

Mol

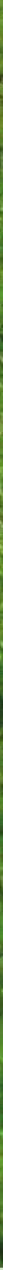

Published as:

Deru, J.G.C., Bloem, J., de Goede, R., Hoekstra, N., Keidel, H., Kloen, H., Nierop, A., Rutgers, M., Schouten, T., van den Akker, J., Brussaard, L., van Eekeren, N., 2019. Predicting soil N supply and yield parameters in peat grasslands. Applied Soil Ecology 134, 77-84.

https://doi.org/10.1016/j.apsoil.2018.10.018. 



\begin{abstract}
Considerable nitrogen $(\mathrm{N})$ mineralization occurs in drained peat soils in use for dairy grassland, due to aerobic decomposition of soil organic matter (SOM). $\mathrm{N}$ losses may be limited by matching grass $\mathrm{N}$ uptake with $\mathrm{N}$ mineralization and by adapting on-farm fertilization schemes to soil $\mathrm{N}$ supply (SNS) and apparent $\mathrm{N}$ recovery (ANR). Previous attempts to predict SNS of peat grasslands from soil parameters have been unsuccessful, partly due to high variation in SNS between sites and years. In this paper, we present field data from twenty dairy grasslands on drained peat (29-65\% SOM; Terric Histosols). Grass yield parameters (e.g. SNS and ANR) were compared with a comprehensive data set of soil biotic and abiotic properties measured at the start of the growing season, and with $\mathrm{N}$ mineralization calculated from these data. SNS ranged between 171 and $377 \mathrm{~kg} \mathrm{~N} \mathrm{ha}^{-1}$ (mean: $264 \mathrm{~kg} \mathrm{~N} \mathrm{ha}^{-1}$ ) during the growing season. Soil $\mathrm{N}$ mineralization estimated by laboratory incubation and by foodweb-based production ecological calculations gave similar mean values with slightly higher coefficients of variation, but correlations with SNS were not significant. Regression analysis with soil properties showed a positive correlation between SNS and soil Ca:Mg ratio and a negative correlation between fertilized grass yield and soil C:SOM ratio. No significant models were found for ANR. Based on our data and on literature, we conclude that these parameters indicate linkages between grass yield and soil physical-hydrological properties such as soil structure and water availability. In particular, the C:SOM ratio in these soils with high organic matter content may be an indicator of water repellency, and our results suggest that grass growth is limited by drought more than by nutrient availability.
\end{abstract}

\title{
Keywords
}

Soil nitrogen supply; grass yield; $\mathrm{N}$ mineralization; apparent $\mathrm{N}$ recovery; soil biota; soil chemical-physical quality; Terric Histosols 


\subsection{Introduction}

Maximizing nutrient use efficiency and minimizing environmental impact are growing challenges for agriculture worldwide. In combination with increasing restrictions on the use of external inputs, this requires a re-evaluation of present farming practices (Erisman et al., 2016, 2015). Moreover, agriculture considerably influences global warming via its effect on the emission of carbon dioxide $\left(\mathrm{CO}_{2}\right)$ from soil carbon (C) pools into the atmosphere (Lal, 2008). This is particularly the case for agriculture on drained peat soils: these soils represent only $0.3 \%$ of the global land area but contribute $6 \%$ of the total anthropogenic $\mathrm{CO}_{2}$ emission (Joosten, 2011), because of decomposition of soil organic matter (SOM) under oxic conditions (Armentano, 1980; Kasimir-Klemedtsson et al., 1997). Compared to original peat soils, agricultural peat soils contain higher amounts of nitrogen (N) due to the historical addition of organic material such as manure, crop residues and ditch sludge (Brouns, 2016; Sonneveld and Lantinga, 2011). Aerobic decomposition of SOM in drained peat leads therefore to mineralization of substantial amounts of organic $\mathrm{N}$ that can contribute to the $\mathrm{N}$ demand of crops. However, mineralized $\mathrm{N}$ may also be denitrified and lost to the atmosphere as nitrous oxide (Van Beek et al., 2004a).

To reduce $\mathrm{N}$ losses from dairy grasslands, grass $\mathrm{N}$ uptake should match $\mathrm{N}$ mineralization, and $\mathrm{N}$ fertilization rates should be advised based on reliable predictions. Under the assumption that in optimal growth conditions most mineralized $\mathrm{N}$ from soil is taken up by grass, the unfertilized herbage $\mathrm{N}$ yield can be used as a proxy for the "soil $\mathrm{N}$ supply" (SNS) (Hassink, 1995a; Vellinga and André, 1999). In the Netherlands, a sitespecific prediction of SNS for mineral soils based on soil parameters such as SOM and $\mathrm{N}_{\text {total }}$ is used in the grassland fertilization guideline (Hassink, 1995b; Van Eekeren et al., 2010; Vellinga and André, 1999). On drained peat however, no site-specific SNS is currently used (www.bemestingsadvies.nl). Until c. 1980, when drainage depth in peat regions in the Netherlands was regularly increased, SNS reached up to c. $500 \mathrm{~kg} \mathrm{~N} \mathrm{ha}^{-1}$ per growing season (Schothorst, 1977). SNS was positively correlated with depth of groundwater table, probably due to mineralization of easily degradable $\mathrm{N}$ in newly drained peat layers (Van Kekem, 2004). In later studies in grasslands with stable drainage depths, SNS was generally lower ( 85 - $315 \mathrm{~kg} \mathrm{~N} \mathrm{ha}^{-1}$ ) and the variation was no longer explained by groundwater table, but by summer rainfall (Hassink, 1995a; Sonneveld and Lantinga, 2011; Van Beek et al., 2004b; Van Kekem, 2004; Vellinga and André, 1999). SNS on peat is more variable and 
generally higher than for mineral soils (126 - $192 \mathrm{~kg} \mathrm{~N} \mathrm{ha}^{-1} \mathrm{y}^{-1}$ ) (Hassink, 1995b; Van Eekeren et al., 2010; Vellinga and André, 1999). Attempts to find soil properties that can explain variation in SNS are scarce and have not been successful for peat soils (Hassink, 1996), leading to a fixed SNS of $250 \mathrm{~kg} \mathrm{~N} \mathrm{ha}^{-1} \mathrm{y}^{-1}$ in the present grassland fertilization guideline. With the high variation in realized SNS, the lack of site-specific prediction leads to low nutrient use efficiency and high losses of applied nutrients in many cases, or to insufficient fertilizer applications and unnecessarily low yields. Additionally, the fixed SNS is problematic for dairy farms on peat because it gives an over- or underestimation of the $\mathrm{N}$ use efficiency in the mandatory Annual Nutrient Cycle Assessment (Aarts et al., 2015). Hence, an adequate prediction of SNS on peat grasslands would benefit both farmers and society. Recently, Rashid et al. (2014a) used a combination of soil incubation methods with production ecological model calculations based on abundances of soil organisms to predict $\mathrm{N}$ mineralization in grassland soils, and showed a good match with SNS on two peat and two sandy sites. Their results suggest that soil hydrology, chemistry and microbiology may determine SNS on peat, as well as soil meso- and macrofauna. However, this method has not yet been validated for a larger number of sites and a wider SNS range. The linkages between soil biotic and abiotic properties and yield parameters of peat grasslands remain therefore uncertain.

Under fertilized conditions, the apparent $N$ recovery (ANR) is a measure of the uptake of applied $\mathrm{N}$ and may reveal potential $\mathrm{N}$ losses. Based on 60 years of grassland experiments in the Netherlands, Vellinga and André (1999) found ANR on peat of to be $60 \%$ at a fertilization rate of $200 \mathrm{~kg} \mathrm{~N}$, which was c. $10 \%$ lower than on mineral soils. This was explained by the higher SNS of peat soils. On sandy soils, variation in ANR (35 - 102\%) was predicted by the number of enchytraeids, possibly indicating a balanced decomposition of SOM (Van Eekeren et al., 2010). To our knowledge, ANR on peat soils has not been studied in relation to soil parameters previously.

In this paper, we address the variation in SNS, ANR and fertilized grass dry matter (DM) and $\mathrm{N}$ yield across twenty dairy grasslands in the western Dutch peat area. We relate these yield parameters to a comprehensive data set of soil biotic and abiotic properties, measured at the start of the growing season, and to $\mathrm{N}$ mineralization calculated from these data. For an adequate representation of the variation and to minimize site-specific and weather effects on the results, twenty dairy grasslands (replicates) were sampled in one growing season (Van Eekeren et al., 2010). The objective was to find soil properties that 
determine the variation in grass yield parameters on drained peat. We focus especially on SNS, as this value is of great importance for developing efficient site-specific fertilization schemes. In general, we hypothesize that grass yield parameters are positively correlated with parameters of soil organic matter decomposition such as potential $\mathrm{C}$ and $\mathrm{N}$ mineralization. More specifically, we hypothesize that a good estimation of SNS can be provided by production ecological calculations, or with the combination of potential $\mathrm{N}$ mineralization (based on laboratory incubation of sieved soil) with modeled earthworm $\mathrm{N}$ mineralization (which is not included in the incubation due to soil sieving).

\subsection{Materials and methods}

\subsubsection{Experimental sites}

We selected twenty dairy grasslands on drained peat soils (Terric Histosols; FAO 2015) in the western peat area of the Netherlands. The grasslands had an average ditch water level in the summer ranging from 30 to $60 \mathrm{~cm}$ below soil surface and a history of mixed grazing and cutting and were dominated by Lolium perenne L., Poa trivialis L. and Poa pratensis L. Other site information is provided in Table S3.1 (supplementary material). The year before the experiment was conducted, the grasslands received on average $140 \mathrm{~kg} \mathrm{~N} \mathrm{ha}^{-1}$ as inorganic fertilizer and $216 \mathrm{~kg} \mathrm{~N} \mathrm{ha}^{-1}$ as organic fertilizer (mainly slit-injected cattle slurry; not including excretion during grazing) as part of regular management by the farmers. This is in line with the Dutch fertilization guideline for grasslands on peat (www.bemestingsadvies.nl). The main soil and botanical characteristics of the twenty sites are presented in Table 3.1.

In each grassland, being the experimental unit, an experimental field $(14 \times 9 \mathrm{~m})$ consisting of three plots was laid out in February 2010: two $4 \times 9 \mathrm{~m}$ plots for grass production measurements and one $6 \times 9 \mathrm{~m}$ plot for measurement of soil and botanical parameters (Fig. S3.1). Of the two grass production plots, one plot was fertilized with calcium ammonium nitrate $(27 \% \mathrm{~N})$ at a rate of $200 \mathrm{~kg} \mathrm{~N} \mathrm{ha}^{-1} \mathrm{yr}^{-1}(120 \mathrm{~kg}$ before the first cut and $80 \mathrm{~kg}$ before the second cut; this is a common rate in the peat region), whereas the other plot was not fertilized with $\mathrm{N}$; both plots received ample $\mathrm{P}$ and $\mathrm{K}$ fertilizer. The 6 $\times 9 \mathrm{~m}$ plot for measurement of soil parameters and botanical composition was not fertilized at all during the year of measurements. This experimental design was used to 
Table 3.1 Main soil characteristics and botanical composition of dairy grasslands on drained peat soils $(n=20)$ (Deru et al., 2018a).

\begin{tabular}{|c|c|c|c|c|}
\hline Parameter & Unit & Mean & $\begin{array}{l}\text { Standard } \\
\text { deviation }\end{array}$ & Range \\
\hline Soil bulk density & $\mathrm{g} \mathrm{cm}^{-3}$ & 0.54 & 0.09 & $0.39-0.75$ \\
\hline Soil organic matter (SOM) & g.100 g dry soil ${ }^{-1}$ & 43.8 & 8.8 & $29.2-64.7$ \\
\hline$C_{\text {total }}$ & g.100 g dry soil ${ }^{-1}$ & 22.4 & 4.5 & $14.2-31.8$ \\
\hline $\mathrm{N}_{\text {total }}$ & g.100 g dry soil ${ }^{-1}$ & 2.01 & 0.46 & $1.25-2.99$ \\
\hline$P_{\text {total }}$ & g.100 g dry soil ${ }^{-1}$ & 0.73 & 0.11 & $0.60-0.99$ \\
\hline $\mathrm{pH}_{\mathrm{KCl}}$ & - & 4.8 & 0.3 & $4.3-5.4$ \\
\hline Average ditch water level (summer) & $\mathrm{cm}$ below soil surface & 49 & 8 & $60-30$ \\
\hline Monocotyledons & $\%$ cover & 83 & 11 & $60-95$ \\
\hline Dicotylendons & $\%$ cover & 9 & 10 & $0-35$ \\
\hline
\end{tabular}

measure three types of parameters and characterize each of the twenty grasslands in a uniform way (Van Eekeren et al., 2010): (i) the grass $\mathrm{N}$ yield in the plot without $\mathrm{N}$ fertilization, but with $\mathrm{P}$ and $\mathrm{K}$ to prevent these nutrients to become limiting, provided the SNS of these grasslands (Hassink, 1995b), (ii) the $\mathrm{N}$-fertilized grass yield measured in the NPK-fertilized plot was a measure of the grass production level in the normal dairy farming practice and was used with SNS for calculation of ANR, and (iii) the soil biological, chemical and physical parameters measured at the start of the growing season and without recent fertilization provided the "baseline" soil properties of the twenty grasslands without short term effects of fertilization.

\subsubsection{Grass measurements}

Grass in the production plots was harvested four times in 2010 (17-21 May, 28 June-2 July, 16-20 August and 29 September-7 October) at a stubble height of $6 \mathrm{~cm}$ using a Haldrup plot harvester (J. Haldrup a/s, Løgstør, Denmark). Harvested grass was weighed and a sub-sample was taken for dry matter (DM) and $\mathrm{N}$ analysis. DM was determined after drying at $70{ }^{\circ} \mathrm{C}$ for $48 \mathrm{~h}$ and total $\mathrm{N}$ (Kjeldahl) was analyzed in dry material. The grass $\mathrm{N}$ yield in the grass production plot without $\mathrm{N}$ but with $\mathrm{P}$ and $\mathrm{K}$ fertilizer was used as a measure for the soil $\mathrm{N}$ supply (SNS; kg N ha ${ }^{-1}$ ) (Hassink, 1995a; Vellinga and André, 1999). Apparent $\mathrm{N}$ recovery (ANR; $\mathrm{kg} \mathrm{N} . \mathrm{kg} \mathrm{N}^{-1}$ ), the extra $\mathrm{N}$ yield in relation to the amount of applied fertilizer $N$, was calculated as ( $N$ yield(fertilized) $-N$ yield(non-fertilized)) / $(N$ fertilization rate) (Vellinga and André, 1999). 


\subsubsection{Soil parameters and calculations of $\mathbf{N}$ mineralization}

Soil measurements in the $6 \times 9 \mathrm{~m}$ plots were carried out at the start of the growing season, in April 2010, as described in Deru et al. (2018a). For the present paper, we used a subset of the soil data of Deru et al. (2018a) (dairy grasslands, $n=20$ ), including 81 soil biological parameters (describing microorganisms, nematodes, enchytraeids, earthworms and microarthropods), 19 soil chemical parameters (organic matter characteristics, nutrient supply and availability) and 22 soil physical parameters (water content, texture, structure, penetration resistance). A full list of parameters is presented in Table S3.2, and data statistics are published in Deru et al. (2018a).

For each site, we calculated the soil $\mathrm{N}$ mineralization during the growing season until the last grass harvest (March-September included) using the soil biological parameters of April 2010 and based on three approaches as described in Rashid et al. (2014a): (i) potential $\mathrm{N}$ mineralization measured in laboratory incubations of soil, (ii) production ecological calculations of $\mathrm{N}$ mineralization by soil organisms and (iii) a combination of (i) and (ii).

(i) Potential $\mathrm{N}$ mineralization ( $\mu \mathrm{g} \mathrm{N} . \mathrm{g} \mathrm{soil}{ }^{-1} \cdot$ week $^{-1}$ ) was measured in laboratory incubation of field-moist samples (Deru et al., 2018a). Mineralization during the growing season was estimated with the value of April for the whole period, using a $Q_{10}$ of 3 to correct for field temperature per month. The $Q_{10}$ of 3 was based on Bloem et al. (1994), Table 1, which shows the average in situ $\mathrm{N}$ mineralization measured in the field (average soil temperature $9.5^{\circ} \mathrm{C}$ ) and the potential $\mathrm{N}$ mineralization measured in the lab at $20^{\circ} \mathrm{C}$ : the ratio is 3 in the $0-25 \mathrm{~cm}$ soil layer. Soil temperature $(-10 \mathrm{~cm})$ was taken from the nearest weather station (De Bilt) (KNMI, 2010). Upscaling to $\mathrm{kg} \mathrm{N} \mathrm{ha}^{-1}$ was done with measured site-specific soil bulk densities (Table S3.1).

(ii) Production ecological calculations based on the method developed by Didden et al. (1994) were carried out for protozoa, bacteria, fungi, nematodes, enchytraeids, earthworms and microarthropods. $\mathrm{N}$ mineralization was calculated using physiological parameter values as listed in Table S3.3 (Supplementary material) and with abundances and biomasses in April 2010 taken from Deru et al. (2018a). The calculations are described in detail in Rashid et al. (2014a). Briefly, C respiration of organisms was calculated using their individual fresh weight and abundance, then corrected for soil temperature (KNMI, 2010) with a groupspecific $Q_{10}$ value, and finally converted to $\mathrm{N}$ mineralization with assimilation efficiency $\left(A_{\mathrm{e}}\right)$, production efficiency $\left(P_{\mathrm{e}}\right)$ and body and food $\mathrm{C} / \mathrm{N}$ ratio (Table S3.3). For protozoa (amoebae and flagellates), abundance in peat soils was taken from Finlay et al. (2000) as 
a fixed amount for all sites. For bacteria and fungi, $C$ respiration was calculated with their biomass ( $\mathrm{kg} \mathrm{C} \mathrm{ha}^{-1}$, using site-specific soil bulk density) and respiration rate constants (0.27 and 0.29, respectively). Body weights of enchytraeids, endogeic and epigeic earthworms were corrected for gut content $(7 \%, 15 \%$ and $10 \%$ of the fresh weight, respectively (Persson et al., 1980; Van Vliet et al., 2007)). In contrast to Rashid et al. (2014a), production ecological calculations in this paper include site-specific data on nematodes and microarthropods, and calculations were based on organism abundance in April only. $\mathrm{N}$ mineralization was calculated over the period in which grass production and SNS were measured (March to September: 7 months) with soil temperatures taken from the weather station De Bilt (KNMI, 2010) for all sites.

(iii) Potential $\mathrm{N}$ mineralization from approach (i) was combined with modeled earthworm $\mathrm{N}$ mineralization from approach (ii) (which is not included in approach (i) due to soil sieving) following Rashid et al. (2014a).

\subsubsection{Statistical analyses}

Statistical analysis was performed using Matlab (version 8.6 R2015b, The Mathworks). Before further statistical analyses, the Lilliefors test (performing a Kolmogorov-Smirnov test for normality with mean and variance unknown) was carried out on non-transformed parameter values $(x)$ and on log-transformed values with added constants ( 1 or 10$)$. When necessary to obtain a normal distribution, log-transformed parameter values were used in the further statistical analyses. Pearson's correlation coefficients were calculated for all parameters. Furthermore, linkages between grass yield parameters and soil properties were explored based on the method used by Van Eekeren et al. (2010) and Andersson et al. (2011), using stepwise linear regression with permutation tests to determine model significance. For each grass yield parameter (SNS, ANR, fertilized N yield and fertilized DM yield), potential regression models were generated based on separate sets of descriptive parameters (soil biological (set B), soil chemical (set C), soil physical (set P), or all parameters combined (set BCP)), from which a minimum of one and a maximum of three parameters were selected. Subsequent selection of statistically significant models was based on random permutation tests performed on the complete stepwise regression procedure. For each maximum number (1-3) of descriptive parameters, we tested for 999 permutations whether the permuted $r^{2}$ was equal to or above $90 \%$ of the calculated true $r^{2}$. In other words, we assessed if there was a significant gap (> 10\%) between the 
calculated true $r^{2}$ and the distribution of all permuted $r^{2} s$. Random permutation tests resulting in a $P$-value below 0.05 were considered to be significant.

\subsection{Results}

\subsubsection{Grass yield parameters}

Grass yield parameters are presented in Table 3.2. Mean SNS was $264 \mathrm{~kg} \mathrm{~N} \mathrm{ha}^{-1}$, and fertilized $\mathrm{N}$ yield was $130 \mathrm{~kg} \mathrm{~N} \mathrm{ha}^{-1}$ higher. This resulted in a ANR of $0.65 \mathrm{~kg} \mathrm{~N} \mathrm{~kg} \mathrm{~N}^{-1}$. SNS showed a much higher variation across sites than fertilized yield. SNS was positively correlated with fertilized $\mathrm{N}$ yield $(r=+0.83, P<0.01)$ and negatively with ANR $(r=-0.69, P$ $<0.01)$.

Table 3.2 Grass yield parameters in dairy grasslands on drained peat soils during the growing season (total of four cuts): means, coefficients of variation and ranges $(n=20)$.

\begin{tabular}{llrrc}
\hline Parameter & Unit & Mean & CV (\%) & Range \\
\hline Soil N supply (SNS) & $\mathrm{kg} \mathrm{N} \mathrm{ha}^{-1}$ & 264 & 18.9 & $171-377$ \\
Apparent N recovery (ANR) & ${\mathrm{kg} \mathrm{N} . \mathrm{kg} \mathrm{N}^{-1}}$ & 0.65 & 21.8 & $0.41-1.00$ \\
Fertilized N yield & $\mathrm{kg} \mathrm{N} \mathrm{ha}^{-1}$ & 394 & 9.2 & $335-480$ \\
Fertilized DM yield & $\mathrm{Mg} \mathrm{DM} \mathrm{ha}^{-1}$ & 13.1 & 9.4 & $11.6-15.9$ \\
\hline
\end{tabular}

\subsubsection{Soil N mineralization}

The mean value and range of potential $\mathrm{N}$ mineralization determined by laboratory incubation and subsequently scaled up to mineralization at field temperature during the growing season were somewhat lower, but comparable to the mean and range of production ecological calculations (Table 3.3). The groups of soil organisms contributed not equally to the total $\mathrm{N}$ mineralization: $\mathrm{N}$ mineralization by earthworms was highest (37\%), that of protozoa, bacteria and fungi together was $53 \%$, and that of enchytraeids, nematodes and microarthropods together was $10 \%$. There was no significant correlation between potential $\mathrm{N}$ mineralization by laboratory incubation and $\mathrm{N}$ mineralization by soil organisms ( $r=-0.19)$. Excluding earthworm mineralization from the total production ecological mineralization did not improve the correlation with potential $\mathrm{N}$ mineralization (which is measured in sieved soil without earthworms) $(r=-0.12, P>0.05)$. 
Table 3.3 Calculated $\mathrm{N}$ mineralization ( $\mathrm{kg} \mathrm{N}^{-1}$ haring March - September included) in dairy grasslands on drained peat soils: means, coefficients of variation and ranges $(n=20)$

\begin{tabular}{lrrc}
\hline Parameter & Mean & CV (\%) & Range \\
\hline Potential N mineralization (PNM) & 238.1 & 37.2 & $93-406$ \\
Production ecology & 263.3 & 23.8 & $168-420$ \\
Protozoa & 41.5 & 0 & - \\
Bacteria & 47.7 & 28.9 & $25-79$ \\
Fungi & 52.1 & 30.9 & $27-80$ \\
Nematodes & 7.9 & 19.6 & $5-13$ \\
Enchytraeids & 14.3 & 35.3 & $5-23$ \\
Earthworms & 98.7 & 53.0 & $25-219$ \\
Microarthropods & 1.0 & 38.7 & $0-2$ \\
PNM + Earthworms & 336.8 & 28.4 & $207-581$ \\
\hline
\end{tabular}

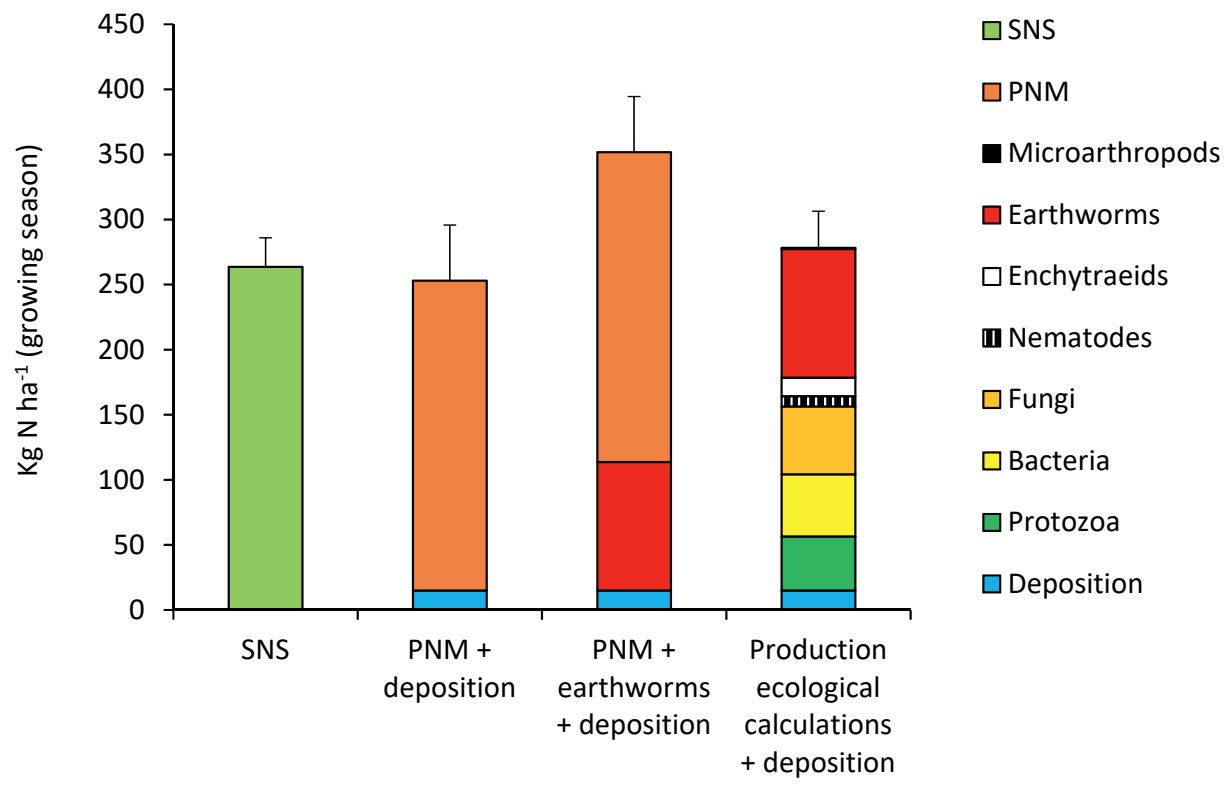

Figure 3.1 Comparison of soil $\mathrm{N}$ supply (SNS) and three methods to predict it, based on measurements in 20 dairy grasslands on peat soils. SNS: grass $\mathrm{N}$ yield in unfertilized plots; PNM: potential $\mathrm{N}$ mineralization determined by laboratory incubation of sieved soil; earthworms: $\mathrm{N}$ mineralization by earthworms estimated by production ecological calculations. Error bars represent $2 \times S E(n=20)$ on the total. 


\subsubsection{Grass yield linked with $\mathbf{N}$ mineralization and soil properties}

Mean SNS was $79 \%$ of mean potential $\mathrm{N}$ mineralization by laboratory incubation plus earthworm $\mathrm{N}$ mineralization and $\mathrm{N}$ deposition, and 99\% of total $\mathrm{N}$ mineralization by soil organisms (production ecological calculations) plus $\mathrm{N}$ deposition (15 $\mathrm{kg} \mathrm{N} \mathrm{ha}^{-1}$; as used by Rashid et al. (2014a)) (Fig. 3.1). However, no significant correlations ( $P>0.05$ ) were found between SNS and potential N mineralization by laboratory incubation $(r=+0.18)$, SNS and potential $\mathrm{N}$ mineralization by laboratory incubation plus earthworm $\mathrm{N}$ mineralization $(r=$ +0.22 ) or SNS and total N mineralization by soil organisms through production ecological calculations $(r=+0.24)$. Significant correlations were found between yield parameters and various soil biological, chemical and physical parameters (Table 3.4). Stepwise regression with $P$-values based on permutation tests resulted in models with higher $P$-values, and these models were significant with chemical and physical soil parameters only (Table 3.5). SNS was positively correlated with Ca:Mg ratio (Fig. 3.2a), also in combination with C:SOM ratio or soil air content at pF 2 (negative regression weights) (Table 3.5). For ANR, no significant regression model was found. Fertilized $\mathrm{N}$ yield was described by a combined model with Ca saturation (positive regression weight) and C:SOM ratio (negative regression weight). Similarly, fertilized DM yield was described by C:SOM ratio (negative correlation, Fig. 3.2b) with increased model performance when Ca saturation (positive regression weight) was added. However, the model for fertilized DM yield with highest $r^{2}$ was achieved with soil physical parameters: penetration resistance at 0-10 cm, load bearing capacity (both negative regression weights) and sand percentage (positive regression weight) (Table 3.5). 
Table 3.4 Significant Pearson's correlations between grass yield parameters and soil biological (set B), soil chemical (set C) and soil physical (set P) parameters from Deru et al. (2018a) (dairy grasslands, $n=20$ ).

\begin{tabular}{|c|c|c|c|c|c|}
\hline Set & Parameter & $\begin{array}{c}\text { Soil N supply } \\
\text { (SNS) }\end{array}$ & $\begin{array}{c}\text { Apparent } \mathrm{N} \\
\text { recovery (ANR) }\end{array}$ & $\begin{array}{l}\text { Fertilized } \\
\mathrm{N} \text { yield }\end{array}$ & $\begin{array}{l}\text { Fertilized } \\
\text { DM yield }\end{array}$ \\
\hline \multirow[t]{12}{*}{$B$} & Fungal biomass & & & & $0.47^{*}$ \\
\hline & Nematode taxa & & $-0.46^{*}$ & & \\
\hline & Nematode plant parasitic index & $-0.49 *$ & $0.49 *$ & & \\
\hline & Enchytraeids (number / biomass) & & & & $0.48 * / 0.45 *$ \\
\hline & Enchytraeus enchytraeids (number) & & & $0.51 *$ & \\
\hline & Earthworm taxa & & $0.52 *$ & & \\
\hline & Collembola taxa & & & & $0.46 *$ \\
\hline & Acari taxa & & $0.47^{*}$ & & \\
\hline & Bacterivorous microarthropods (number/\%) & & & $0.45 * / 0.48 *$ & \\
\hline & Fungivorous microarthropods (\%) & & & $0.61 * *$ & $0.64 * *$ \\
\hline & Omnivorous microarthropods (\%) & & $-0.49 *$ & & \\
\hline & Combined abundance index & & & & $0.50 *$ \\
\hline \multirow[t]{6}{*}{$\mathrm{C}$} & Plant available $\mathrm{P}\left(\mathrm{P}_{\mathrm{AL}}\right)$ & & & $0.45 *$ & \\
\hline & $\mathrm{pH}_{\mathrm{KCl}}$ & & & $0.46 *$ & \\
\hline & C:SOM ratio & $-0.56 *$ & & $-0.55 *$ & $-0.72 * *$ \\
\hline & $\%$ Calcium saturation & $0.52 *$ & & $0.64 * *$ & $0.49 *$ \\
\hline & $\%$ Magnesium saturation & & $0.46 *$ & & \\
\hline & Ca:Mg ratio & $0.70 * *$ & $-0.47 *$ & $0.59 * *$ & $0.52 *$ \\
\hline \multirow[t]{7}{*}{$P$} & Water content at $\mathrm{pF} 2$ & & $-0.45^{*}$ & & \\
\hline & Air content at $\mathrm{pF} 2$ & $-0.62 * *$ & $0.62 * *$ & & $-0.45^{*}$ \\
\hline & \% Clay & $-0.52 *$ & & & $-0.51 *$ \\
\hline & $\%$ Sand & $0.55 *$ & & $0.59 * *$ & $0.65 * *$ \\
\hline & Penetration resistance $0-10 \mathrm{~cm}$ & & & $-0.45 *$ & $-0.70 * *$ \\
\hline & Penetration resistance $10-20 \mathrm{~cm}$ & & & & $-0.64 * *$ \\
\hline & Load bearing capacity & & & $-0.49 *$ & $-0.58 * *$ \\
\hline
\end{tabular}

* $P \leq 0.05$;* $P \leq 0.01$
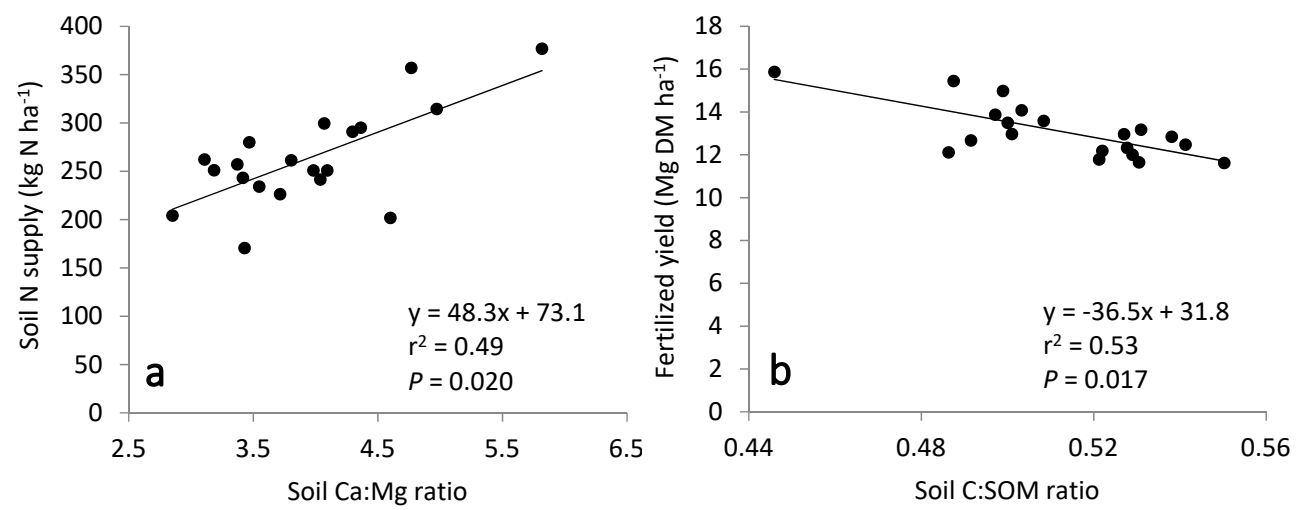

Figure 3.2 Regression models for soil $\mathrm{N}$ supply (SNS) as a function of soil Ca:Mg ratio (a), and for fertilized grass dry matter (DM) yield as a function of soil C:SOM ratio (b) in 20 dairy grasslands on peat soils. $P$-values calculated with random permutation tests. 
Table 3.5 Permuted stepwise regression analysis with grass yield parameters against soil biological (set B), chemical (set C) and physical (set P) parameters from Deru et al. (2018a) (dairy grasslands, $n=20$ ), including a minimum of one and a maximum of three descriptive parameters in the model. Models based on more than one set are computed with the combined data from those sets. Results are presented for significant models only ( $P \leq 0.05 ; P$ calculated with permutation tests).

\begin{tabular}{|c|c|c|c|c|c|c|}
\hline $\begin{array}{l}\text { Grass yield: response } \\
\text { parameter }\end{array}$ & Set & $\begin{array}{l}1^{\text {st }} \text { model } \\
\text { parameter }\end{array}$ & $\begin{array}{l}2^{\text {nd }} \text { model } \\
\text { parameter }\end{array}$ & $\begin{array}{l}3^{\text {rd }} \text { model } \\
\text { parameter }\end{array}$ & $P$ & $r^{2}$ \\
\hline \multirow[t]{3}{*}{ Soil N supply (SNS) } & C & +Ca:Mg ratio & & & 0.021 & 0.49 \\
\hline & c & +Ca:Mg ratio & -C:SOM ratio & & 0.049 & 0.56 \\
\hline & $\mathrm{CP}$ & +Ca:Mg ratio & -Air content pF 2 & & 0.045 & 0.66 \\
\hline Apparent $\mathrm{N}$ recovery (ANR) & - & & & & n.s. & \\
\hline Fertilized $\mathrm{N}$ yield & C & $+\%$ Ca saturation & -C:SOM ratio & & 0.031 & 0.57 \\
\hline \multirow[t]{5}{*}{ Fertilized DM yield } & C & -C:SOM ratio & & & 0.013 & 0.53 \\
\hline & C & -C:SOM ratio & $+\%$ Ca saturation & & 0.017 & 0.63 \\
\hline & $\mathrm{P}^{+}$ & $-P R 0-10 \mathrm{~cm}$ & & & 0.009 & 0.49 \\
\hline & $\mathrm{P}^{+}$ & -PR $0-10 \mathrm{~cm}$ & $+\%$ Sand & & 0.004 & 0.74 \\
\hline & $\mathrm{P}^{+}$ & $-P R 0-10 \mathrm{~cm}$ & $+\%$ Sand & $\begin{array}{l}\text {-Load bearing } \\
\text { capacity }\end{array}$ & 0.009 & 0.78 \\
\hline
\end{tabular}

${ }^{{ }^{\top} S a m e}$ models found for the combined set BCP; PR.: penetration resistance.

\subsection{Discussion}

The variation in SNS measured across our twenty dairy grasslands on drained peat (171-377 kg N ha-1 $\mathrm{yr}^{-1}$ ) falls within the range found on peat soils by other authors (Hassink, 1995a; Sonneveld and Lantinga, 2011; Van Beek et al., 2004b; Van Kekem, 2004; Vellinga and André, 1999) and is large. This underlines the need of a prediction tool for SNS that is sensitive to differences across grassland sites within the peat region to arrive at optimal use of $\mathrm{N}$ fertilizer. The aim of this study was to find soil parameters that predict the observed variation in SNS and other grass yield parameters across twenty dairy grasslands on peat.

\subsubsection{Grass $\mathbf{N}$ uptake and soil $\mathbf{N}$ mineralization}

In contrast with our hypothesis, the grass production parameters were not significantly explained by $\mathrm{C}$ or $\mathrm{N}$ mineralization parameters. For SNS, this is in accordance with the work of Hassink (1996), who found no correlation between SNS and soil organic N content, microbial $\mathrm{N}$ and $\mathrm{N}$ mineralization in similar soils. However, Rashid et al. (2014a) suggested production-ecological modeling to explain the gap between SNS and soil N mineralization calculated from laboratory incubation measurements, based on two peat grasslands. In 
our data from twenty grasslands, average SNS was close to total $\mathrm{N}$ mineralization by soil organisms or potential $\mathrm{N}$ mineralization (difference $<15 \mathrm{~kg} \mathrm{~N} \mathrm{ha}^{-1}$ ), but lower than potential $\mathrm{N}$ mineralization plus earthworm $\mathrm{N}$ mineralization (difference: $88 \mathrm{~kg} \mathrm{~N} \mathrm{ha}{ }^{-1}$; Table 3.2 and 3.3 after correction for $\mathrm{N}$ deposition). Assuming relatively low $\mathrm{N}$ losses from unfertilized peat grasslands (denitrification: 20 to $40 \mathrm{~kg} \mathrm{~N} \mathrm{ha}^{-1} \mathrm{yr}^{-1}$ (Van Beek et al., 2004b); leaching to groundwater: < $10 \mathrm{~kg} \mathrm{~N} \mathrm{ha}^{-1} \mathrm{yr}^{-1}$ (Van Beek, 2007)), the average SNS of the twenty grasslands appears to be well in line with estimated $\mathrm{N}$ mineralization from soil organisms. However, to increase the $\mathrm{N}$ use efficiency of individual dairy grasslands within a region, not only an accurate match between means is needed, but also the variation across sites must be well predicted. The abovementioned differences of means between SNS and estimated soil $\mathrm{N}$ mineralization have high standard deviations (70-97 kg N ha-1), and the correlation between these parameters were low and not significant. So, our calculations of $\mathrm{N}$ mineralization did not appear to yield suitable predictors for SNS for individual grasslands.

A possible explanation for the absence of significant correlations between SNS and soil $\mathrm{N}$ mineralization may be the lack of site-specific data on factors that influence $\mathrm{N}$ availability, such as protozoa, $\mathrm{N}$ deposition, $\mathrm{N}$ denitrification, soil temperature, as well as temporal dynamics in soil moisture and abundance and activity of soil organisms during the growing season. Of those factors, protozoa contribute substantially to the $\mathrm{N}$ mineralization in agricultural soils (De Ruiter et al., 1993) and are sensitive to soil moisture (Van Dijk et al., 2009). The moisture content in the rooted zone of drained peat is high in winter and low during dry periods (Schothorst, 1982). Although the twenty grasslands in this study were situated within the same region and climatic conditions and had comparable management of ditch water level, individual differences in soil hydrology may have influenced $\mathrm{N}$ mineralization and grass $\mathrm{N}$ uptake considerably. In relation to that, $\mathrm{N}$ mineralization or $\mathrm{N}$ availability may not have been the most limiting factor for grass $\mathrm{N}$ uptake, at least during part of the growing season. Schothorst (1982) showed strong stagnation of grass growth in dry summers on peat soils with relatively high groundwater levels, due to nearly absent capillary flow. Moreover, deep grass root development in peat is hindered, which may be caused by the high groundwater level during the winter in combination with subsoil acidity (Lynch and Wojciechowski, 2015; Schothorst, 1982).

Summarizing, we must reject the hypothesis that simple estimations of the $\mathrm{N}$ mineralization during the growing season, based on soil data at the start of the growing 
season, can be used as predictors for SNS of dairy grasslands on peat soils. Possibly, the production ecological approach to calculate $\mathrm{N}$ mineralization needs more site-specific and temporal data on abundance and activity of soil biota and on soil temperature and water availability. However, for the development of a site-specific fertilizer $\mathrm{N}$ application recommendation, SNS must be predicted by simple parameters that can be measured before or at the start of the growing season. Therefore, it may be relevant to explore factors other than $\mathrm{N}$ availability during the season that influence SNS and herbage yield parameters, for example water availability or soil structure. This is discussed in the next section.

\subsubsection{Prediction of SNS and fertilized grass yield with soil properties}

Although variation in SNS did not correlate with that of calculated $\mathrm{N}$ mineralization, it did so significantly with various soil chemical and physical properties (Table 3.4), indicating that $\mathrm{N}$ yield was not (only) limited by $\mathrm{N}$ availability. SNS was explained by Ca:Mg ratio and soil air content at pF 2 (Table 3.5). In a linear model with Ca:Mg ratio as single explanatory variable, SNS increased with $48 \mathrm{~kg} \mathrm{~N} \mathrm{ha}^{-1} \mathrm{yr}^{-1}$ for each unit increase in Ca:Mg (Fig. 3.2a), reaching the highest value at a Ca:Mg ratio of about 6. This is close to the "ideal" $\mathrm{Ca}: \mathrm{Mg}$ ratio of 65:10 which has been suggested in the past for arable crops on mineral soils (Albrecht, 1975; Bear and Toth, 1948). This result is surprising, because the existence of an "ideal" Ca:Mg ratio has been challenged based on empirical studies showing no influence of cation ratios on soil fertility (Kopittke and Menzies, 2007). However, Dontsova and Norton (2002) showed that an increase in Mg saturation (with decreased Ca:Mg ratio) on clay soils reduced aggregate stability and water infiltration into the soil. In our study, neither Ca saturation, Mg saturation, nor Ca:Mg ratio was significantly correlated with water infiltration rate, but Ca saturation was positively correlated with soil crumbliness ( $r$ $=+0.50 ; P<0.05)$ and $\mathrm{Mg}$ saturation was negatively correlated with water holding capacity (water content at $\mathrm{pF} 2 ; \mathrm{r}=-0.58 ; P<0.01$ ). These correlations may indicate differences in soil physical-hydrological properties across sites related to $\mathrm{Ca}$ and $\mathrm{Mg}$ saturation in line with Dontsova and Norton (2002). Apparently, a combination of higher Ca saturation (more crumbly soil structure) and lower $\mathrm{Mg}$ saturation (higher water holding capacity) led to higher SNS in our study. Both SNS and Ca:Mg ratio did not correlate significantly with soil $\mathrm{pH}_{\mathrm{KCl}}$, thus a causality between $\mathrm{Ca}: \mathrm{Mg}$ ratio and SNS is presumed not to be driven by 
differences in soil acidity and its effects on $\mathrm{N}$ mineralization. Therefore, a causality between SNS and Ca:Mg ratio seems to be related to soil structure and water availability.

SNS correlated less strongly with Ca saturation than with the Ca:Mg ratio, but for fertilized $\mathrm{N}$ yield the opposite was found (Table 3.4). Ca saturation itself - but not Ca:Mg ratio - was significantly correlated to $\mathrm{pH}_{\mathrm{KCl}}(r=+0.84 ; P<0.01)$. Accordingly, fertilized $\mathrm{N}$ yield - but not SNS - correlated positively with $\mathrm{pH}_{\mathrm{KCl}}(r=+0.46 ; P<0.05)$. The amount of dissolved organic carbon and rate of microbial breakdown are known to increase with soil pH (Marschner and Wilczynski, 1991; Oste et al., 2002; You et al., 1999), resulting in nutrient mineralization that can benefit plant growth. However, if the relationship between grass $\mathrm{N}$ yield and $\mathrm{Ca}$ saturation was influenced by soil $\mathrm{pH}$ and higher $\mathrm{N}$ mineralization, we would have expected a stronger correlation in the unfertilized plots (SNS) instead of in the fertilized plots (fertilized $\mathrm{N}$ yield). This may be an indication that on these drained peat soils, grass $\mathrm{N}$ yield was not limited by $\mathrm{N}$ availability, but by other (soil) factors.

Both fertilized DM and $\mathrm{N}$ yields were negatively correlated with C:SOM ratio (Table 3.4), but not with $\mathrm{C}_{\text {total }}$ or SOM individually (data not shown). C:SOM ratio was also selected as second model parameter after Ca:Mg in explaining the variation in SNS. The C:SOM ratio measured in our grasslands ranged between 0.45 and 0.55 , which represents the lower end of the range $(0.4-0.7)$ that can be expected in soil (Pribyl, 2010). In soils with organic C contents higher than 10\%, C:SOM ratio was found to be 0.54 in the topsoil and 0.61 in the subsoil, indicating a distinction with depth (Pribyl, 2010). Accordingly, Klingenfuß et al. (2014) observed lower C:SOM ratios in drained topsoils than in water saturated subsoils of peatlands, due to lower $\mathrm{C}$ contents in the topsoils. A reduction of the topsoil C:SOM ratio in drained peat may occur due to secondary soil development characterized by mineralization and humification (Kalisz et al., 2010; Klingenfuß et al., 2014), in addition to input of new organic matter from manure and grass residues in dairy grasslands. In our study, the relation between C:SOM ratio and grass yield did not seem to be linked to nutrient mineralization because the correlation was stronger in fertilized plots than in unfertilized plots, and stronger for DM yield than for $\mathrm{N}$ yield. As far as we know, C:SOM ratio has not previously been selected as explanatory parameter for grass yield. In our data set, C:SOM ratio was positively correlated with penetration resistance $(r=+0.69 ; P<0.01)$, which is sensitive to both soil structure (compaction, bulk density) and soil moisture (Elbanna and Witney, 1987). Therefore, the C:SOM ratio of soils high in organic matter (> 
25\%) may be an indicator of soil physical and hydrological properties that influence grass yield, in line with the relation between Ca:Mg ratio and SNS.

A possible explanation for the correlation between C:SOM ratio and grass yield may be that in our case, C:SOM ratio is an indicator of soil water repellency, which affects soil water availability for both plant growth and soil biota regulating $\mathrm{N}$ mineralization. Water repellency of soil is mainly caused by organic molecules consisting of a non-polar hydrophobic $\mathrm{CH}$ chain with a polar hydrophilic functional group at one end (Doerr et al., 2000) and there is a positive relation between molecular weight and water repellency (Mao et al., 2014; Morley et al., 2005). Large organic molecules have generally longer Cchains and are relatively more carbon-rich, and thus have a higher C:SOM ratio. Soil C:SOM ratio may therefore be an indicator of water repellency in peat and this could explain the correlation with grass yield in the present study. Despite the generally high water levels in ditches and surface water in peat areas ( 30 to $60 \mathrm{~cm}$ below soil surface), it is known that grass growth on peat soils can easily be limited by drought during summer (Schothorst, 1977; Van der Meer et al., 2004), because water transport from ditches and groundwater to the rooted soil layer is strongly hampered (Schothorst, 1982). In these soils, waterholding capacity of the rooted zone may therefore be an important factor for grass growth. As a result of differences in water repellency of organic soils (Berglund and Persson, 1996; Dekker and Ritsema, 2000), water availability may differ among sites, especially following rewetting after a drought period (Schwärzel et al., 2002). Therefore, in temperate climates, water repellency effects occur mainly after the summer, i.e. at the time of increased precipitation while temperature and radiation are still sufficient for grass growth. This is exactly what was found in the present study: C:SOM ratio correlated most strongly with the fertilized DM yield of the $4^{\text {th }}$ cut (Table 3.6); the regrowth period of this cut was wet and followed a long dry period in June and July (KNMI, 2010). So, C:SOM ratio appeared to indicate water repellency of the soil, which seemed to have influenced grass yield negatively.

Summarizing, we observed correlations between grass yield and soil properties (Ca:Mg ratio, Ca saturation, C:SOM ratio) suggesting that variation in yield across sites was more influenced by soil physical-hydrological factors such as water availability, than by $\mathrm{N}$ mineralization. 
Table 3.6 Pearson's correlations between C:SOM ratio and fertilized grass yield parameters per grass cut

\begin{tabular}{lrrrrr}
\hline Yield parameter & $1^{\text {st }}$ cut & $2^{\text {nd }}$ cut & $3^{\text {rd }}$ cut & $4^{\text {th }}$ cut & Total \\
\hline Fertilized N yield & -0.34 & 0.18 & -0.35 & -0.69 & -0.55 \\
Fertilized DM yield & -0.53 & -0.15 & -0.31 & -0.73 & -0.72 \\
\hline
\end{tabular}

\subsubsection{Challenges for minimizing losses and maximizing grass yield on drained peat soils}

Our results indicate that high $\mathrm{N}$ losses can potentially occur in fertilized grass, because mean ANR was $0.65 \mathrm{~kg} \mathrm{~N}$ per kg fertilizer $\mathrm{N}$ applied, with a minimum value of $0.41 \mathrm{~kg} \mathrm{~N}$ (Table 3.2). Hence, on average, 35\% of the applied $\mathrm{N}$ was not harvested in herbage but may have been denitrified (Kroeze et al., 2003) or leached to the groundwater if not stored in soil. Although a mean ANR of 0.6 - 0.7 is common in grassland (Van Eekeren et al., 2010; Vellinga and André, 1999), an increased $\mathrm{N}$ utilization would benefit farmers and society. Especially on peat soils, that have a SNS of $171-377 \mathrm{~kg} \mathrm{ha}^{-1}$ and for which $\mathrm{N}$ fertilizer rates are based on a theoretical SNS of $250 \mathrm{~kg} \mathrm{ha}^{-1}$, adapting the $\mathrm{N}$ fertilization to the local SNS may increase ANR and minimize N losses. In our study, predictors for SNS, such as Ca:Mg ratio and C:SOM ratio, indicate that SNS is sensitive to differences in soil physicalhydrological properties. Although these predictors explained part of the spatial variation in SNS during one growing season, additional research is needed to quantify their sensitivity to variation across years due to weather and climate differences.

\subsection{Conclusions}

Our study on twenty dairy grasslands on drained peat soils showed that SNS was high in comparison to mineral soils. The ANR was $65 \%$ on average, which is in line with values on mineral soils and indicates that considerable losses of applied $\mathrm{N}$ may occur in fertilized peat grasslands.

Mean SNS corresponded to mean $\mathrm{N}$ mineralization by soil organisms calculated from measurements at the start of the growing season. However, the site-specific variation in SNS and other grass yield parameters was not significantly correlated with soil $\mathrm{N}$ mineralization calculated on the basis of soil data measured at the start of the growing season, but was significantly correlated with Ca:Mg ratio, Ca saturation and C:SOM ratio. 
Based on these and other correlations in our data set and on literature, we infer that grass yield was more influenced by water availability than by $\mathrm{N}$ mineralization, and that especially the correlation with C:SOM ratio was indicative of soil water repellency that influenced grass yield negatively. Further research is required to address the causality of relationships between grass yield, water availability and soil properties of drained peat and to develop prediction tools, taking into account the variation across sites and years.

\section{Acknowledgements}

The authors acknowledge Wim Dijkman, Frank Lenssinck, Gerard Jagers op Akkerhuis and Sjoerd Smits for their contributions to the project, and Gerben Bakker, Jaap Bogte, Popko Bolhuis, Riekje Bruinenberg, Henri den Hollander, Wim Dimmers, Hans Dullaert, René Groenen, Tamás Salánki, Erik Steenbergen, Karel van Houwelingen, Eef Velthorst, Meint Veningat, and An Vos for their practical assistance. Christien Ettema is acknowledged for text-editing and improving the English of this manuscript.

\section{Funding}

This study was funded by Stichting Kennisontwikkeling en Kennisoverdracht Bodem, Provincie Noord-Holland, Provincie Zuid-Holland, Provincie Utrecht, and the Interdepartementaal Programma Biodiversiteit. Access to data from the Dutch Soil Quality Network was supported by the Ministry of Infrastructure and Environment within the RIVM project BEO (M/607406). Jaap Bloem was supported by the research program KB 21 "Sustainable Food and non-Food production" funded by the Netherlands Ministry of Economic Affairs and Climate Policy. 


\section{Appendix: Supplementary material}

Table S3.1 Coordinates, main soil characteristics $(0-10 \mathrm{~cm})$ and botanical composition of the twenty dairy grasslands on peat (Deru et al., 2018a).

\begin{tabular}{|c|c|c|c|c|c|c|c|c|}
\hline \multirow{2}{*}{$\begin{array}{l}\text { Site } \\
\mathrm{nr}\end{array}$} & \multicolumn{2}{|c|}{ Coordinates } & \multirow{2}{*}{$\begin{array}{c}\text { SOM } \\
\text { g } 100 \mathrm{~g}^{-1}\end{array}$} & \multirow{2}{*}{$\begin{array}{c}\text { Bulk } \\
\text { density } \\
\mathrm{g} \mathrm{cm}^{-3}\end{array}$} & \multirow[b]{2}{*}{$\mathrm{pH}_{\mathrm{KCl}}$} & \multirow{2}{*}{$\begin{array}{c}\text { Mean ditch } \\
\text { water level in } \\
\text { summer }(\mathrm{cm})\end{array}$} & \multicolumn{2}{|c|}{$\begin{array}{c}\text { Botanical composition } \\
\text { (\% soil cover) }\end{array}$} \\
\hline & 'North & 'East & & & & & Grasses & Dicots \\
\hline 01 & $52^{\circ} 32.0$ & $4^{\circ} 59.0$ & 39.4 & 0.53 & 4.8 & -60 & 80 & 20 \\
\hline 02 & $52^{\circ} 31.8$ & $4^{\circ} 58.9$ & 49.7 & 0.45 & 4.6 & -60 & 90 & 10 \\
\hline 03 & $52^{\circ} 31.9$ & $4^{\circ} 59.6$ & 41.5 & 0.53 & 4.9 & -60 & 92 & 3 \\
\hline 04 & $52^{\circ} 31.7$ & $4^{\circ} 59.7$ & 38.9 & 0.52 & 5.4 & -60 & 83 & 2 \\
\hline 05 & $52^{\circ} 15.8$ & $4^{\circ} 54.9$ & 41.0 & 0.48 & 4.8 & -50 & 90 & 5 \\
\hline 06 & $52^{\circ} 16.0$ & $4^{\circ} 54.7$ & 39.7 & 0.39 & 4.9 & -50 & 90 & 0 \\
\hline 07 & $52^{\circ} 03.0$ & $4^{\circ} 42.7$ & 37.9 & 0.59 & 5.2 & -50 & 85 & 10 \\
\hline 08 & $52^{\circ} 03.0$ & $4^{\circ} 42.2$ & 35.9 & 0.63 & 5.2 & -50 & 93 & 2 \\
\hline 09 & $51^{\circ} 56.3$ & $4^{\circ} 43.4$ & 52.3 & 0.50 & 5.2 & -50 & 95 & 0 \\
\hline 10 & $51^{\circ} 56.1$ & $4^{\circ} 43.2$ & 45.9 & 0.57 & 4.5 & -50 & 95 & 0 \\
\hline 11 & $51^{\circ} 57.1$ & $4^{\circ} 43.3$ & 51.5 & 0.50 & 4.9 & -50 & 87 & 3 \\
\hline 12 & $51^{\circ} 57.3$ & $4^{\circ} 43.0$ & 55.0 & 0.48 & 4.6 & -40 & 75 & 5 \\
\hline 13 & $52^{\circ} 08.2$ & $4^{\circ} 55.8$ & 40.1 & 0.49 & 5.0 & -30 & 89 & 1 \\
\hline 14 & $52^{\circ} 10.1$ & $4^{\circ} 54.1$ & 39.8 & 0.58 & 4.4 & -50 & 80 & 15 \\
\hline 15 & $52^{\circ} 09.7$ & $4^{\circ} 53.7$ & 38.1 & 0.62 & 4.6 & -50 & 83 & 2 \\
\hline 16 & $52^{\circ} 06.1$ & $4^{\circ} 45.9$ & 30.8 & 0.70 & 4.5 & -40 & 65 & 30 \\
\hline 17 & $52^{\circ} 06.2$ & $4^{\circ} 46.2$ & 29.2 & 0.75 & 4.3 & -40 & 85 & 5 \\
\hline 18 & $52^{\circ} 08.3$ & $4^{\circ} 50.2$ & 50.1 & 0.54 & 4.8 & -55 & 60 & 35 \\
\hline 19 & $52^{\circ} 08.4$ & $4^{\circ} 49.9$ & 64.7 & 0.44 & 4.6 & -50 & 68 & 12 \\
\hline 20 & $52^{\circ} 08.6$ & $4^{\circ} 49.8$ & 53.7 & 0.48 & 4.9 & -40 & 65 & 15 \\
\hline
\end{tabular}

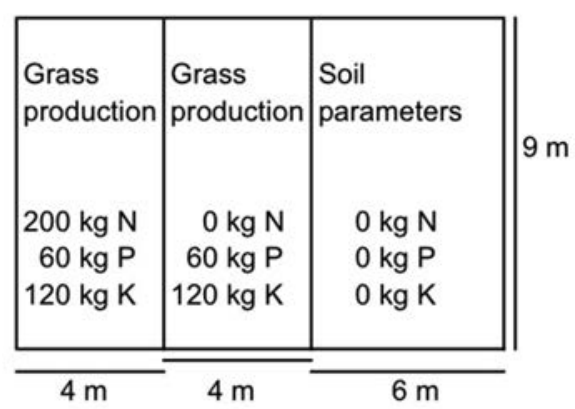

Figure S3.1 Experimental layout per dairy grassland site. Amounts of fertilizer in $\mathrm{kg} \mathrm{ha}^{-1} \mathrm{yr}^{-1}$. 
Table S3.2 Soil biological, chemical and physical data from Deru et al. (2018a) measured at twenty dairy grassland sites on drained peat, and used in the calculations and statistical analysis. Numbers in brackets are the numbers of parameters per set or group (total: 122).

\begin{tabular}{|c|c|c|}
\hline Set & Group & Parameters \\
\hline \multirow[t]{6}{*}{$\begin{array}{l}\text { Soil } \\
\text { biological } \\
\text { (81) }\end{array}$} & Microorganisms (7) & $\begin{array}{l}\text { Fungal biomass; \% active hyphae; bacterial biomass; bacterial growth } \\
\text { rate (thymidine and leucine incorporation); metabolic quotient; } \\
\text { fungal-bacterial ratio }\end{array}$ \\
\hline & Nematodes (18) & $\begin{array}{l}\text { Total number; taxonomic richness; diversity index; maturity index; } \\
\text { plant parasitic index; channel index; enrichment index; structure } \\
\text { index; number and percentage of fungivorous, bacterivorous, } \\
\text { herbivorous, carnivorous and omnivorous nematodes }\end{array}$ \\
\hline & Enchytraeids (17) & $\begin{array}{l}\text { Total number; total biomass; mean body weight; taxonomic richness; } \\
\text { diversity index; number and percentage of enchytraeids in the } \\
\text { Fridericia, Marionina and Enchytraeus groups; taxonomic richness and } \\
\text { biomass in the Fridericia, Marionina and Enchytraeus groups }\end{array}$ \\
\hline & Earthworms (9) & $\begin{array}{l}\text { Total number; total biomass; mean body weight; taxonomic richness; } \\
\text { diversity index; number of adults; number of juveniles; number of } \\
\text { epigeic and endogeic earthworms }\end{array}$ \\
\hline & $\begin{array}{l}\text { Microarthropods } \\
\text { (27) }\end{array}$ & $\begin{array}{l}\text { Total number; taxonomic richness; diversity index; number and } \\
\text { taxonomic richness of mites and collembola; number and percentage } \\
\text { of microarthropods in ten feeding guilds. }\end{array}$ \\
\hline & $\begin{array}{l}\text { Combined indices } \\
\text { (3) }\end{array}$ & $\begin{array}{l}\text { Number of soil faunal taxa; combined soil faunal taxonomic index; } \\
\text { combined soil faunal abundance index }\end{array}$ \\
\hline \multirow[t]{2}{*}{$\begin{array}{l}\text { Soil chemical } \\
\text { (19) }\end{array}$} & $\begin{array}{l}\text { Organic matter } \\
\text { characteristics (8) }\end{array}$ & $\begin{array}{l}\text { Soil organic matter (SOM); } \mathrm{C}_{\text {total }} \text {; potential } \mathrm{C} \text { mineralization; hot water } \\
\text { extractable } \mathrm{C}(\mathrm{HWC}) \text {; water soluble } \mathrm{C}(\mathrm{WSC}) ; \mathrm{N}_{\text {total }} ; \mathrm{C}: \mathrm{N} \text { ratio; C:SOM } \\
\text { ratio }\end{array}$ \\
\hline & $\begin{array}{l}\text { Nutrient supply and } \\
\text { availability (11) }\end{array}$ & $\begin{array}{l}\text { Potential } \mathrm{N} \text { mineralization; potentially mineralizable } \mathrm{N} ; \mathrm{NO}_{3}{ }^{-} ; \mathrm{P}_{\mathrm{AL}} \text {; } \\
\mathrm{P}_{\text {total }} ; \mathrm{pH}_{\mathrm{KCl}} ; \mathrm{CEC} \text {; saturation } \% \text { of } \mathrm{Ca}, \mathrm{Mg} \text { and } \mathrm{K} \text {; Ca:Mg ratio }\end{array}$ \\
\hline \multirow[t]{3}{*}{$\begin{array}{l}\text { Soil physical } \\
(22)\end{array}$} & $\begin{array}{l}\text { Soil-water-air } \\
\text { system (7) }\end{array}$ & $\begin{array}{l}\text { Actual field water content; water content at } \mathrm{pF} 2 \text {; air content at pF 2; } \\
\text { bulk density; number of macropores at } 10 \text { and } 20 \mathrm{~cm} \text { depth; water } \\
\text { infiltration rate }\end{array}$ \\
\hline & $\begin{array}{l}\text { Soil texture and } \\
\text { structure (11) }\end{array}$ & $\begin{array}{l}\text { Clay }(<2 \mu \mathrm{m}) \text {, silt }(>2<50 \mu \mathrm{m}) \text {, and sand }(>50 \mu \mathrm{m}) \text { percentage; } \\
\text { percentage of crumbs, sub-angular blocky elements, and angular } \\
\text { blocky elements }(0-10 \mathrm{~cm} \text { and } 10-20 \mathrm{~cm}) \text {, number of roots at } 10 \text { and } \\
20 \mathrm{~cm} \text { depth }\end{array}$ \\
\hline & Soil resistance (4) & $\begin{array}{l}\text { Penetration resistance in 0-10 cm, 10-20 and } 20-30 \mathrm{~cm} \text { layers; load } \\
\text { bearing capacity }\end{array}$ \\
\hline
\end{tabular}


Table S3.3 Abundance and physiological parameter values of soil organisms used as input for the production ecological calculations (Deru et al., 2018a; Didden et al., 1994; Rashid et al., 2014a; Van Vliet et al., 2007). $a$ and $b$ : constants for the respiration equations, determined at temperature $T$. $A_{\mathrm{e}}$ : assimilation efficiency (proportion of food assimilated into blood stream). $P_{\mathrm{e}}$ : production efficiency (proportion of assimilated energy converted into biomass production)

\begin{tabular}{|c|c|c|c|c|c|c|c|c|c|c|}
\hline Functional group & Abundance $\mathbb{P}^{\mathbb{P}}$ & $\begin{array}{r}\text { Individual } \\
\text { weight } \\
\text { ( } \mu \text { g fresh) }\end{array}$ & $\begin{array}{r}\mathrm{C} / \mathrm{N} \\
\text { body }\end{array}$ & $a$ & $b$ & $\mathrm{~T}\left({ }^{\circ} \mathrm{C}\right)$ & $Q_{10}$ & $A_{\mathrm{e}}$ & $P_{\mathrm{e}}$ & $\begin{array}{r}\mathrm{C} / \mathrm{N} \\
\text { food }\end{array}$ \\
\hline \multicolumn{11}{|l|}{ Protozoa } \\
\hline Amoebae & $9.8 \times 10^{8}$ & $0.48 \times 10^{-2}$ & 5 & 13.5 & 0.8 & 10 & 2 & 0.95 & 0.38 & 6 \\
\hline Flagellates & $2.3 \times 10^{9}$ & $0.24 \times 10^{-2}$ & 5 & 13.5 & 0.8 & 10 & 2 & 0.95 & 0.38 & 5 \\
\hline Bacteria & 238.3 & n.a. & 5 & n.a. & n.a. & 25 & 2.2 & 1.0 & 0.3 & 14 \\
\hline Fungi & 65.8 & n.a. & 10 & n.a. & n.a. & 25 & 2.2 & 1.0 & 0.3 & 14 \\
\hline \multicolumn{11}{|l|}{ Nematodes } \\
\hline Bacterivorous & $17.3 \times 10^{6}$ & 0.11 & 5 & 29.25 & 0.72 & 20 & 3 & 0.6 & 0.22 & 5 \\
\hline Fungivorous & $0.9 \times 10^{6}$ & 0.06 & 5 & 29.25 & 0.72 & 20 & 3 & 0.38 & 0.14 & 10 \\
\hline Phytophagous & $23.5 \times 10^{6}$ & 0.11 & 5 & 29.25 & 0.72 & 20 & 3 & 0.25 & 0.09 & 10 \\
\hline $\begin{array}{l}\text { Omnivorous/ } \\
\text { predatory }\end{array}$ & $3.8 \times 10^{6}$ & 0.76 & 5 & 29.25 & 0.72 & 20 & 3 & 0.5 & 0.19 & 5 \\
\hline Enchytraeids $^{+}$ & $31.6 \times 10^{3}$ & $0.41 \times 10^{3}$ & 5 & 33.6 & 0.67 & 20 & 2 & 0.28 & 0.11 & 8.8 \\
\hline \multicolumn{11}{|l|}{ Earthworms ${ }^{\ddagger}$} \\
\hline Endogeic $^{\dagger}$ & 393.6 & $0.22 \times 10^{6}$ & 5 & 78 & 0.91 & 19 & 2 & 0.03 & 0.1 & 12.8 \\
\hline Epigeic $^{+}$ & 193.4 & $0.23 \times 10^{6}$ & 5 & 93 & 0.84 & 19 & 2 & 0.1 & 0.2 & 8.3 \\
\hline \multicolumn{11}{|l|}{ Acari } \\
\hline Bacterivorous & $1.6 \times 10^{3}$ & 0.21 & 8 & 102 & 0.87 & 10 & 3 & 0.5 & 0.18 & 5 \\
\hline Nematophagous & $1.2 \times 10^{3}$ & 3.16 & 8 & 102 & 0.87 & 10 & 3 & 0.9 & 0.32 & 5 \\
\hline $\begin{array}{l}\text { Omnivorous } \\
\text { (Chewing) }\end{array}$ & $22.7 \times 10^{3}$ & 1.89 & 8 & 7.2 & 0.69 & 10 & 3 & 0.5 & 0.18 & 10 \\
\hline $\begin{array}{l}\text { Omnivorous } \\
\text { (Suckling) }\end{array}$ & $13.7 \times 10^{3}$ & 0.68 & 8 & 102 & 0.87 & 10 & 3 & 0.5 & 0.18 & 10 \\
\hline Predatory & $8.8 \times 10^{3}$ & 5.88 & 8 & 102 & 0.87 & 10 & 3 & 0.6 & 0.21 & 7.2 \\
\hline \multicolumn{11}{|l|}{ Collembola } \\
\hline Omnivorous & $32.2 \times 10^{3}$ & 8.23 & 8 & 63 & 0.73 & 18 & 2.5 & 0.5 & 0.18 & 10 \\
\hline Predatory & $1.0 \times 10^{3}$ & 4.96 & 8 & 63 & 0.73 & 18 & 2.5 & 0.5 & 0.18 & 5 \\
\hline
\end{tabular}

${ }^{\dagger}$ Mean individual weights taken from Deru et al. (2018a), excluding gut content (see Methods). Standard deviations of individual weights ( $n=20$ ): enchytraeids $0.14 \times 10^{3} \mu \mathrm{g}$; endogeic earthworms $0.07 \times 10^{6} \mu \mathrm{g}$; epigeic earthworms $0.07 \times 10^{6} \mu \mathrm{g}$.

${ }^{\ddagger} A$ Anecic earthworms were not present.

PAbundances in $\mathrm{n} \mathrm{m}^{-2}$, except for bacteria and fungi: $\mu \mathrm{g} \mathrm{C.g} \mathrm{dry} \mathrm{soil}{ }^{-1}$. Abundances of protozoa from Finlay et al. (2000). Abundances of other organisms from Deru et al. (2018a) (means of 20 sites).

n.a.: not applicable (see Methods). 


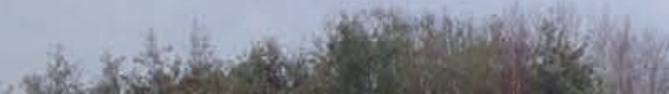

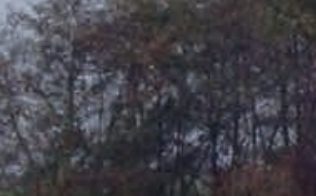

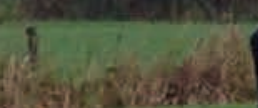

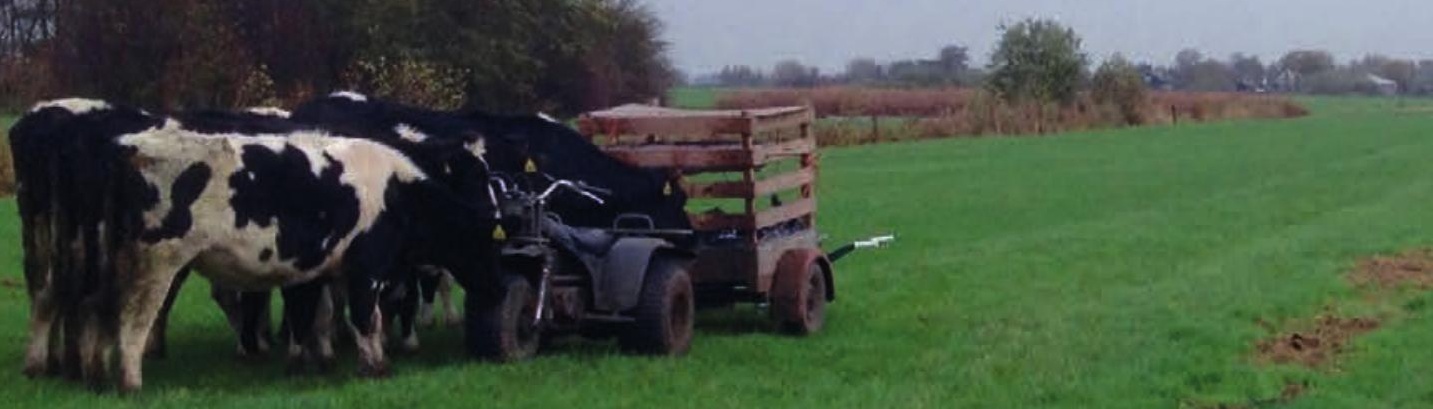

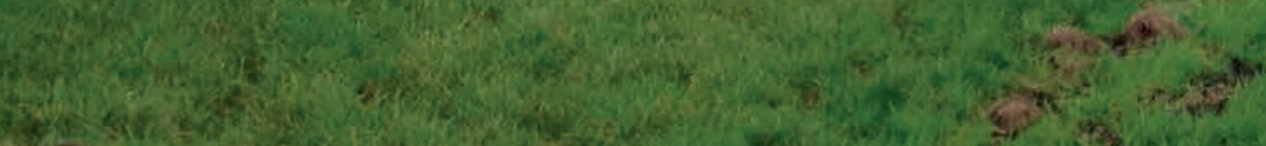

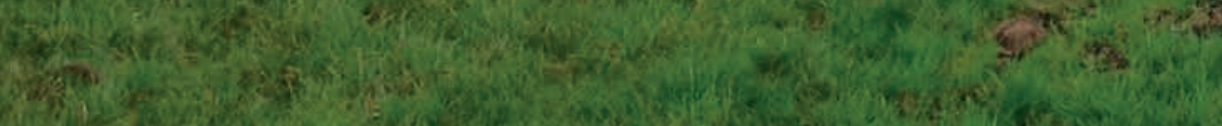

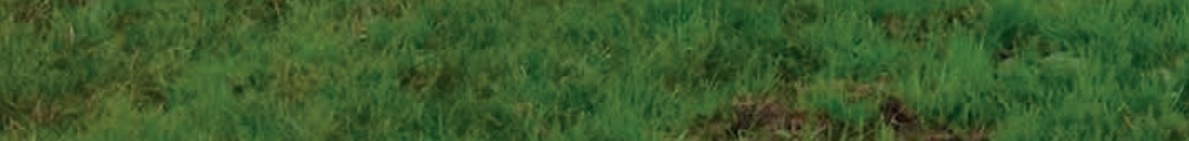

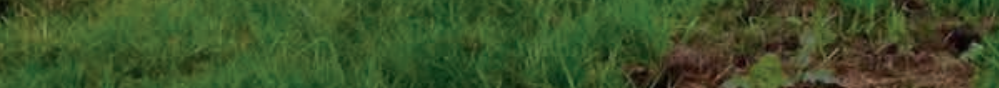

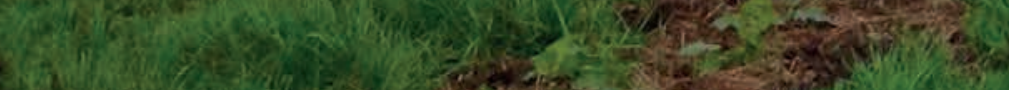

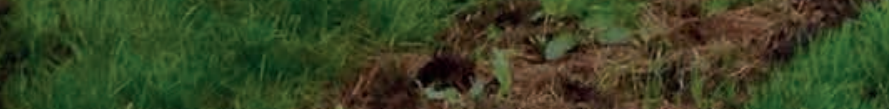

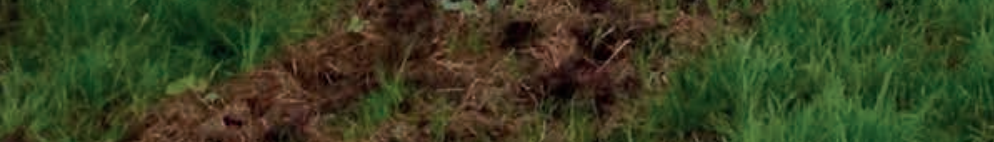

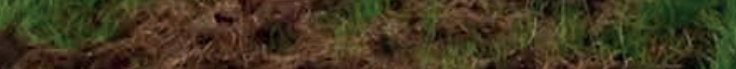
G. 


\section{Chapter 4}

\section{Effects of Ca:Mg ratio and $\mathrm{pH}$ on soil chemical, physical and microbiological properties and grass $\mathbf{N}$ yield in drained peat soil}

Deru, J.G.C., Hoekstra, N., van Agtmaal, M., Bloem, J., de Goede, R., Brussaard, L., van Eekeren, $\mathrm{N}$. Effects of $\mathrm{Ca}: \mathrm{Mg}$ ratio and $\mathrm{pH}$ on soil chemical, physical and microbiological properties and grass $\mathrm{N}$ yield in drained peat soil.

(Under revision for publication in New Zealand Journal of Agricultural Research) 



\begin{abstract}
In a field experiment on three dairy grasslands on peat, four minerals were added to manipulate the soil Ca:Mg ratio with or without effect on $\mathrm{pH}$. The responses of soil properties and grass $\mathrm{N}$ yield were measured. $\mathrm{CaCO}_{3}$ application led to higher soil $\mathrm{Ca}: \mathrm{Mg}$ ratio and $\mathrm{pH}_{\mathrm{KCl}}$ compared to the untreated control, decreased $\mathrm{N}_{\text {total }}$ and $\mathrm{C}_{\text {total }}$, and increased $P$ availability. Grass $N$ yield was increased in the first year, not in the second. Soil parameters indicated positive effects of $\mathrm{pH}$ on SOM decomposition only in soils with high $\mathrm{P}$ availability. $\mathrm{MgCO}_{3}$ reduced the $\mathrm{Ca}: \mathrm{Mg}$ ratio, had little influence on soil parameters and no effect on grass $\mathrm{N}$ yield. In contrast, $\mathrm{CaSO}_{4}$ and $\mathrm{MgSO}_{4}$ did not influence $\mathrm{pH}_{\mathrm{KCl}}$ but reduced grass $\mathrm{N}$ yield in most cases. Results suggest stabilization of organic matter by $\mathrm{Ca}$ binding in the treatments with added $\mathrm{Ca}$. We conclude that grass $\mathrm{N}$ yield was not linked with changes in $\mathrm{Ca}: \mathrm{Mg}$ ratio but with soil $\mathrm{pH}$. The $\mathrm{pH}$ effects on SOM decomposition appeared to depend on $\mathrm{P}$ availability and $\mathrm{Ca}$ binding. Hence, to avoid soil losses of $\mathrm{C}$ and $\mathrm{N}$, the current agricultural advice on $\mathrm{pH}$ management in peat grasslands should be better adapted to local edaphic characteristics.
\end{abstract}

\title{
Keywords
}

Grassland; Histosols; lime; gypsum; kieserite; soil quality; soil organic matter 


\subsection{Introduction}

Peatlands contain one third of the total global soil carbon reservoir (Parish et al., 2008) and peat soils that are drained to be used for agriculture are major contributors to terrestrial $\mathrm{CO}_{2}$ emissions (Kasimir-Klemedtsson et al., 1997; Kluge et al., 2008; Van den Akker et al., 2008). The oxic conditions in the topsoil of drained peat stimulate decomposition and mineralization of the soil organic matter (SOM), also in the untilled permanent grasslands that cover $80 \%$ of the Dutch peat area. Hence, reducing SOM decomposition while maintaining sufficient grass production for dairy farming is a major challenge in those soils. The organic matter of agricultural peatlands consists mainly of old plant residues accumulated during the pre-drainage period, but the topsoil contains considerable amounts of young and nutrient-rich organic matter as well, originating from crop residues, organic manures and ditch sludge (Sonneveld and Lantinga, 2011). Decomposition of SOM in the topsoil is therefore an important source of nutrients such as mineralized $\mathrm{N}$. The amount of $\mathrm{N}$ uptake by grassland during the first year without $\mathrm{N}$ fertilization may range between 85 and $377 \mathrm{~kg} \mathrm{~N} \mathrm{ha}^{-1} \mathrm{yr}^{-1}$ (Deru et al., 2019; Hassink, 1995a; Pijlman et al., 2020; Sonneveld and Lantinga, 2011; Van Beek et al., 2004b; Van Kekem, 2004; Vellinga and André, 1999). From analysis of a large data set including grass $\mathrm{N}$ uptake and the natural variation in soil physical, chemical and biological parameters, Deru et al. (2019) concluded that the Ca:Mg ratio in the topsoil was the best single parameter correlating with unfertilized grass $\mathrm{N}$ yield (i.e. the amount of harvested $\mathrm{N}, \mathrm{a}$ proxy for soil $\mathrm{N}$ supply) in drained peat grasslands. The lack of a correlation with $\mathrm{pH}$ suggested that a higher $\mathrm{Ca}: \mathrm{Mg}$ ratio may increase the uptake of mineralized $\mathrm{N}$ by grassland due to improved soil structure, rooting and water availability without increasing the $\mathrm{N}$ mineralization itself, for which $\mathrm{pH}$, via microbial activity, is assumed to be an important factor (Deru et al., 2018a; Rousk et al., 2011). Literature provides little evidence for a causal relation between the ratio of cations in soil (i.e. Ca and $\mathrm{Mg}$ ) and crop yields (Kopittke and Menzies, 2007), but the Albrecht Theory of an 'ideal' soil Ca:Mg ratio (Albrecht, 1975) is still used by commercial advisors and soil laboratories as a measure of soil quality and in their fertilization advice to farmers. The results presented in Deru et al. (2019) raised the question whether the soil Ca:Mg ratio in peat grasslands can be manipulated to influence the (unfertilized) grass $\mathrm{N}$ uptake without affecting SOM decomposition and $\mathrm{N}$ mineralization, and potentially reduce $\mathrm{N}$ losses. 
In agriculture, minerals such as calcite $\left(\mathrm{CaCO}_{3}\right)$, dolomite $\left(\mathrm{CaMg}\left(\mathrm{CO}_{3}\right)_{2}\right)$, magnesite $\left(\mathrm{MgCO}_{3}\right)$ or gypsum $\left(\mathrm{CaSO}_{4}\right)$ are applied to counteract negative effects of acidification, compaction and/or Ca or Mg deficiency on crop production (Bolan et al., 2003; Goulding, 2016; Haynes, 1984; Hoyt, 1981; Shainberg et al., 1989; Sumner et al., 1990). Manipulation of soil Ca or $\mathrm{Mg}$ with carbonates (e.g. $\mathrm{CaCO}_{3}, \mathrm{MgCO}_{3}$ ) is associated with a rise in $\mathrm{pH}$ (Haynes and Naidu, 1998). On the other hand minerals without carbonate, such as gypsum $\left(\mathrm{CaSO}_{4}\right)$ or kieserite $\left(\mathrm{MgSO}_{4}\right)$, affect soil Ca or $\mathrm{Mg}$ with limited effect on $\mathrm{pH}$ (Bolan et al., 2003; Carter, 1986; Murphy and Stevens, 2010). These minerals, however, have a higher solubility than carbonate minerals and can penetrate deeper into the soil (Reeve and Sumner, 1972). Moreover, the sulfate may induce unwanted internal eutrophication in anoxic peat layers (Beltman et al., 2000; Koerselman et al., 1993). Hence, the effects of such minerals are not straightforward as they may vary with soil chemical, physical and biological conditions (Hamilton et al., 2007; Haynes and Naidu, 1998; Holland et al., 2018; Paradelo et al., 2015) and can change over time after application (Grover et al., 2017; Neale et al., 1997).

So far, little is known about the effects of liming of peat grasslands on soil $\mathrm{N}$ supply and grass production with other minerals than $\mathrm{CaCO}_{3}$. For grasslands on peat soils in the Netherlands, it is advised to reduce soil acidity if $\mathrm{pH}_{\mathrm{KCl}}$ drops below 4.6 (Commissie Bemesting Grasland en Voedergewassen, 2019). This official advice is based on agronomic grounds without explicit reference to effects on peat decomposition and to soil $\mathrm{N}$ supply. However, it is important for the farming practice that the present advice to use minerals that influence the soil Ca:Mg ratio is based on experimental knowledge.

Our objective was to investigate whether the positive relationship between unfertilized grass $\mathrm{N}$ yield and the natural variation in $\mathrm{Ca:Mg}$ ratio in peat soils found by Deru et al. (2019) can be reproduced in a factorial experiment with manipulated Ca:Mg ratio and whether effects can be explained from chemical, physical and microbiological soil properties. A field experiment was carried out during three years on three peat grasslands with different initial soil Ca:Mg ratios to which four minerals with or without expected effect on $\mathrm{pH}$ were added to increase and decrease the $\mathrm{Ca}: \mathrm{Mg}$ ratio. It was hypothesized that (1) increased Ca:Mg ratio - after addition of Ca containing minerals would enhance grass $\mathrm{N}$ yield and that decreased Ca:Mg ratio - after addition of $\mathrm{Mg}$ containing minerals - would reduce grass N yield; 2 ) these effects would be caused by changes in soil physical properties rather than in $\mathrm{N}$ mineralization; (3) addition of $\mathrm{CO}_{3}$ 
containing minerals would increase $\mathrm{pH}$, organic matter decomposition and grass $\mathrm{N}$ yield independently of $\mathrm{Ca}: \mathrm{Mg}$ ratio.

\subsection{Materials and methods}

\subsubsection{Study sites and experimental setup}

A field experiment was conducted on three permanent grasslands (locations $A, B, C$ ) on peat soil (Terric Histosol; FAO 2014) in use by conventional dairy farmers in the west of the Netherlands. The three locations were selected based on their diverging Ca:Mg ratio in the 0-20 cm soil layer: location A had a high (6.9), location B a moderate (4.0) and location $\mathrm{C}$ a low $\mathrm{Ca}: \mathrm{Mg}$ ratio (2.9), which is representative for the range found in this region (Deru et al., 2019). Per location, soil $\mathrm{pH}_{\mathrm{KCl}}$ was 4.8 (A), 4.9 (B) and 4.5 (C) and SOM was 35\% (A), 44\% (B) and 34\% (C). Location $C$ had a relatively low $P$ availability, probably as a result of reduced application of cattle slurry during the period from c. 1980 to 2006 . Field observations in the $\mathbf{0}-80 \mathrm{~cm}$ soil profile and consultation of the Dutch soil map (www.bodemdata.nl) showed that the profiles of the three peat soils were comparable. Soil properties of the three locations are presented in Supplementary Table S4.1.

At each location, a randomized block experiment with five treatments (including an untreated control) in four blocks was laid out, resulting in 20 experimental plots per location and 60 plots in total (plot size $2.8 \times 10 \mathrm{~m}$; sampling and measurements occurred at minimum $0.5 \mathrm{~m}$ from the plot borders). The four minerals used were: $\mathrm{CaCO}_{3}, \mathrm{CaSO}_{4}$, $\mathrm{MgCO}_{3}$, and $\mathrm{MgSO}_{4}$. With these treatments, changes in $\mathrm{Ca}: \mathrm{Mg}$ ratio were to be expected with increased $\mathrm{pH}$ (minerals with $\mathrm{CO}_{3}$ ) or without increased $\mathrm{pH}$ (minerals with $\mathrm{SO}_{4}$ ). Amounts used in the experiment (Table 4.1) were aimed at a strong effect on the Ca:Mg ratio in the soil, as a prerequisite to test the first hypothesis, and were therefore higher

Table 4.1 Amounts of $\mathrm{Ca}, \mathrm{Mg}, \mathrm{CO}_{3}$ and $\mathrm{SO}_{4}$ applied per treatment $\left(\mathrm{kg} \mathrm{ha}^{-1}\right)$. Total application was divided in three equal gifts in February, September and December 2014.

\begin{tabular}{lcccc}
\hline Treatment & $\mathrm{Ca}$ & $\mathrm{Mg}$ & $\mathrm{CO}_{3}$ & $\mathrm{SO}_{4}$ \\
\hline Control & - & - & - & - \\
$\mathrm{CaCO}_{3}$ & 2400 & - & 3590 & - \\
$\mathrm{CaSO}_{4}$ & 2600 & - & - & 6230 \\
$\mathrm{MgCO}_{3}$ & - & 760 & 1870 & - \\
$\mathrm{MgSO}_{4}$ & - & 760 & - & 3000 \\
\hline
\end{tabular}


than common doses for grassland soils but not uncommon in research (Ahmad et al., 2020; Rashid et al., 2014b). The treatments with $\mathrm{CaCO}_{3}$ or $\mathrm{CaSO}_{4}$ were similar in $\mathrm{Ca}$ application, whereas those with $\mathrm{MgCO}_{3}$ or $\mathrm{MgSO}_{4}$ were similar in $\mathrm{Mg}$ application. Ca application was higher than the Mg application, in line with the differences in CEC saturation in soil. Total amounts were applied in three equal parts during 2014: 33\% in February, 33\% in September and 33\% in December.

During the application year (2014), the farmers continued their normal grassland management, which included fertilization, mowing and grazing by cattle. During the monitoring years (2015 and 2016), the plots were not fertilized or grazed. Monthly temperature and precipitation data for 2015 and 2016 are provided in Fig. S4.1. Briefly, both years were characterized with a late start of the growing season, but with warmer summers than the long-term average. The year 2016 started wetter than normal but had a particularly dry summer until October.

\subsubsection{Measurements}

\subsubsection{Soil chemical parameters}

Before the start of the growing season of 2015 (February), soil measurements were carried out to determine whether treatments had the desirable effects on the soil Ca:Mg ratio. At each location and per experimental plot, a soil sample consisting of c. 15 randomly taken soil cores in the 0-20 cm layer was collected (auger diameter $1.2 \mathrm{~cm}$; Eijkelkamp, Giesbeek, the Netherlands) (completely filled cores) and analysed with the same methods as used by Deru et al. (2019). Fresh samples were first sieved through a $1 \mathrm{~cm}$ mesh to remove plant remains and debris, then air-dried and ground to pass a $2 \mathrm{~mm}$ sieve, and subsequently analysed for $\mathrm{Ca}, \mathrm{Mg}, \mathrm{K}, \mathrm{Na}$ and $\mathrm{Al}$ with a Mehlich 3 extractant (Mehlich, 1984) (soil:extractant ratio 1:10). From these data, CEC and Ca:Mg ratio were calculated (Ross and Ketterings, 1995).

In October 2015, another soil sample per experimental plot at the three locations consisting of c. 40 randomly taken soil cores was collected from the 0-10 cm layer (auger diameter $2.3 \mathrm{~cm}$; Eijkelkamp grass plot sampler, Giesbeek, the Netherlands), sieved through a $1 \mathrm{~cm}$ mesh to remove plant remains and debris, and homogenized. Sub-samples were taken for determination of hot water extractable carbon (HWC). HWC was measured according to the method of Ghani et al. (2003). A third sub-sample was dried at $40^{\circ} \mathrm{C}$ prior 
to analysis of soil acidity $\left(\mathrm{pH}_{\mathrm{KCl}}\right)$, soil organic matter $(\mathrm{SOM})$, total carbon $\left(\mathrm{C}_{\text {total }}\right)$, total nitrogen $\left(\mathrm{N}_{\text {total }}\right)$, total phosphorus $\left(\mathrm{P}_{\text {total }}\right)$, ammonium-lactate extractable $\mathrm{P}\left(\mathrm{P}_{\mathrm{AL}}\right)$ and $\mathrm{CaCO}_{3}$ content by Eurofins Agro (Wageningen, the Netherlands). Soil $\mathrm{pH}_{\mathrm{KCl}}$ was measured in $1 \mathrm{M}$ $\mathrm{KCl}$ (NEN-ISO 10390 2005). SOM was determined by loss-on-ignition at $550^{\circ} \mathrm{C}$ during $3 \mathrm{~h}$ after drying at $105^{\circ} \mathrm{C}$ during $6 \mathrm{~h}$ (NEN 5754 2005). $\mathrm{C}_{\text {total }}$ was measured by incineration of dry material at $1150^{\circ} \mathrm{C}$, after which the $\mathrm{CO}_{2}$ produced was determined by an infrared detector (LECO Corporation, St. Joseph, Mich., USA). For determination of $\mathrm{N}_{\text {total, }}$ evolved gasses after incineration were reduced to $\mathrm{N}_{2}$ and measured with a thermal-conductivity detector (LECO Corporation, St. Joseph, Mich., USA). $P_{\text {total }}$ was measured with Fleishmann acid (Houba et al., 1997) and $\mathrm{P}_{\mathrm{AL}}$, commonly used in the Netherlands to assess the $\mathrm{P}$ capacity of grassland soils (Reijneveld et al., 2014), was determined according to Egnér et al. (1960) (NEN 5793). $\mathrm{CaCO}_{3}$ content was analysed with near-infrared spectroscopy (Malley et al., 1999). Concentrations were expressed per soil dry weight.

Plant Root Simulator (PRS ${ }^{\text {TM}}$ ) probes (Western Ag Innovations, Inc., Saskatoon, Canada) with ion exchange membranes were used in 2016 to measure plant-available mineral $\mathrm{N}$ at location $\mathrm{B}$, as possible treatment effects on SOM mineralization would release mineral N. PRS probes were used in the control and $\mathrm{CaCO}_{3}$ treatments during weeks 1,3 and 5 after the first cut. In each plot, four anion and four cation exchange PRS probes were placed at randomly chosen spots. The probes were carefully pressed $12 \mathrm{~cm}$ into the soil, ensuring good contact with the soil for measurement in the $2-8 \mathrm{~cm}$ soil layer, and removed after one week. After removal, the probes were washed free of adhering soil with deionized water, and were eluted with $0.5 \mathrm{~N} \mathrm{HCl}$ solution for 1 hour; the eluate was analysed for $\mathrm{NO}_{3}{ }^{-}$and $\mathrm{NH}_{4}{ }^{+}$by colorimetry using an automated flow injection analysis (FIA) system (Western Ag. Innovations Inc. PRS ${ }^{\mathrm{TM}}$-Probe Operations Manual, 2010).

\subsubsection{Soil physical parameters}

Soil physical measurements were carried out in situ in November 2015 as described below.

Penetration resistance was measured in each experimental plot at the three locations using an electronic penetrologger (Eijkelkamp, Giesbeek, the Netherlands) with a cone with a penetration surface of $2.0 \mathrm{~cm}^{2}$ and a $60^{\circ}$ apex angle. Cone resistance was recorded per $\mathrm{cm}$ of soil depth and expressed as an average of 7 penetrations per layer $(0-10,10-$ 20 , and $20-30 \mathrm{~cm}$ ). Load bearing capacity was measured at 10 randomly chosen spots per 
plot with a penetrometer $\left(5.0 \mathrm{~cm}^{2}\right.$ penetration surface, $60^{\circ}$ apex angle), and was expressed as the average value of the maximum force $(\mathrm{N})$ needed to push the cone through the sod.

Soil structure was determined in two blocks $(20 \times 20 \mathrm{~cm})$ per experimental plot: one collected at 0-10 cm and one at 10-25 cm depth. In each block the percentage of crumbs, sub-angular blocky elements and angular blocky elements was visually estimated as described by Peerlkamp (1959) and Shepherd (2000).

Water infiltration rate was measured at locations $A$ and $B$ at three randomly chosen spots per experimental plot, as described by Van Eekeren et al. (2010). Briefly, a PVC pipe of $15 \mathrm{~cm}$ high and $15 \mathrm{~cm}$ in diameter was put into the soil to a depth of $10 \mathrm{~cm}$. To determine infiltration rate, $500 \mathrm{ml}$ water was poured into each ring and the infiltration time was recorded. When the infiltration time exceeded $15 \mathrm{~min}$, the remaining water volume was estimated and the total infiltration time was calculated by linear extrapolation. From these data, the infiltration rate $\left(\mathrm{mm} \mathrm{min}^{-1}\right)$ was calculated.

\subsubsection{Soil PLFA and tea bag index}

In all experimental plots at location B (the site with median $\mathrm{Ca}: \mathrm{Mg}$ ratio), a field-moist soil sample of c. $200 \mathrm{~g}$ (0-10 cm, auger diameter $2.3 \mathrm{~cm}, 10$ cores) was collected in October 2015 and used for phospholipid fatty acid (PLFA) analyses. PLFA were measured as a proxy of microbial biomass and to examine microbial community structure. PLFA were extracted from $4 \mathrm{~g}$ of fresh soil using the procedure described by Palojärvi (2006), and analysed by gas chromatography (Hewlett-Packard, Palto Alto, CA, USA). PLFA are the primary lipids composing the membranes of living cells. Phospholipid fatty acids i15:0, a15:0, 15:0, i16:0,

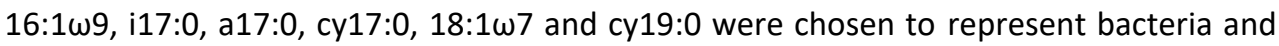
PLFA 18:2 $\omega 6$ was used as a marker of saprotrophic fungi (Hedlund, 2002). The neutral lipid fatty acid (NLFA) 16:1w5, which occurs in storage lipids (such as spores) of arbuscular mycorrhizal fungi (AMF), was used as marker of AMF (Vestberg et al., 2012). The sum of PLFA i15:0, a15:0, i16:0, i17:0 and a17:0 was used as a measure of Gram-positive bacteria, and cy17:0 and cy19:0 as representing Gram-negative bacteria. PLFA 10Me16:0, 10Me17:0 and 10Me18:0 were used for measures of actinomycetes.

In 2016, organic matter decomposition potential was measured in all experimental plots at location B (the site with median Ca:Mg ratio) using the tea bag index (TBI) method (Keuskamp et al., 2013). This method provides an indication of treatment effects on 
decomposition processes in soil, as effects of $\mathrm{pH}$ were expected. This simplified litter bag experiment was carried out with commercially available tetrahedron-shaped synthetic tea bags with sides of $5 \mathrm{~cm}$ containing c. $2 \mathrm{~g}$ of green tea or rooibos tea (Lipton, Unilever). The green tea consisted of $89 \%$ green tea, and the rooibos tea consisted of $93 \%$ rooibos. The mesh size of $0.25 \mathrm{~mm}$ allowed microorganisms and mesofauna to enter the bags, but excluded macrofauna (Keuskamp et al., 2013). The teabags were weighed (mg) and the weight of the labels, string and net material was determined for 10 bags per type of tea and averaged to calculate net weight loss after the incubation. On the $11^{\text {th }}$ of April 2016, the bags were incubated in all experimental plots at location B. In each plot, a $10 \times 10 \times 8$ $\mathrm{cm}$ hole was dug and 4 tea bags of each type were placed at $8 \mathrm{~cm}$ depth. The sod was replaced on top of the teabags and the site was marked with a metal plate. Eighty-five days after incubation, the teabags were dug up, placed in plastic bags and transported to the laboratory. The teabags were air-dried ( $48 \mathrm{~h}$ ) before gently removing all adhering soil and root material. Dry weight was determined after drying at $70^{\circ} \mathrm{C}$ for 24 hours. The stabilization factor $(S)$ and the decomposition rate constant $(k)$ of the incubated organic matter were calculated as outlined by Keuskamp et al. (2013). $S$ is indicative for inhibiting effects of environmental conditions on the breakdown of the added labile organic matter. $k$ represents short-term decomposition of new labile organic matter.

\subsubsection{Grass dry matter and $N$ yield}

Grass dry matter (DM) and N yield were measured in four cuts per year during 2015 and 2016 at all locations with a Haldrup plot harvester (J. Haldrup a/s, Løgstør, Denmark). Harvest dates in 2015 were 19-22 May, 7-9 July, 25-27 August and 7-9 October; harvest dates in 2016 were 19 May, 18 July, 31 August and 12 October. For each harvest, fresh biomass, DM content after drying at $70^{\circ} \mathrm{C}$ for $24 \mathrm{hrs}$ and total $\mathrm{N}$ content (Kjeldahl) were determined. From these data, DM yield $\left(\mathrm{kg} \mathrm{DM} \mathrm{ha}^{-1}\right)$ and $\mathrm{N}$ yield $\left(\mathrm{kg} \mathrm{N} \mathrm{ha}^{-1}\right)$ were calculated per harvest (cut) and summed per year. The yields of the second cut at location C in 2015 were excluded as by mistake cows had entered the experimental field.

\subsubsection{Statistical analyses}

The Shapiro-Wilk test of normality (Royston, 1982) was used in R (version 4.0.3) to test parameter residuals for normal distribution. Parameters that did not meet the assumption 
of normality were log-transformed. Further statistical analyses included analysis of variance (ANOVA), principal component analysis (PCA) and redundancy analysis (RDA).

ANOVA (Genstat $19^{\text {th }}$ edition, VSN international) was carried out on parameters to test for location and treatment effects and their interactions, including block effects per location. In cases of significant effects $(P \leq 0.05)$, differences between means were determined with least significant differences (I.s.d.; $\alpha=5 \%$ ). For soil parameters that were measured at location B only (PRS probes, TBI, PLFA), one-way ANOVA was used to test for treatment effects.

PCA and RDA were carried out in R with packages vegan 2.5-4 and packfor 0.0-8. Analyses including data of the three locations together were carried out with the residuals of the parameter values, calculated by fitting a linear model for location and block effects (location + block). This was done to exclude main location effects, because we were interested in the variation induced by treatments or by treatment $\times$ location interactions only. Analyses including data of one location were carried out with the raw data. PCA was performed on the correlation matrix (of residuals) to visualize the variation of the soil parameters across treatments and provide an overview of correlations between parameters as projected on the principal component planes. RDA was performed to identify relationships between soil parameters and grass $\mathrm{N}$ yield parameters in four separate data sets: one including the three locations and three including one location each. Per separate data set, the number of explanatory soil parameters was first reduced by withdrawing parameters showing strong collinearity one by one, as indicated by a variance inflation factor (VIF) > 10 (Borcard et al., 2011). For RDA including all locations, and for locations $A$ and $C$, the data sets comprised soil chemical and physical parameters. For location B, the data set also included PLFA and TBI parameters, as these were measured at this location. A list of parameters in the reduced data sets for RDA is presented in Table S4.2. Within the RDA analysis, an ordination value for $\mathrm{N}$ yield values was generated and used in subsequent regression. This procedure was followed by permutation tests and a forward selection to identify the most relevant soil parameters explaining grass $N$ yield, which was only run on significant $(P \leq 0.05)$ models. Next, for each significant model, alternative models were computed using the same procedure, but after withdrawing the first selected explanatory parameter from the input data set. This was done to explore which other subsequent significant model parameters would be selected. For models including more than one explanatory parameter, partitioning of variance was 
carried out to calculate adjusted $r^{2}$ per parameter and assess the contribution of each parameter to grass $\mathrm{N}$ yield.

\subsection{Results}

\subsubsection{Soil properties}

The PCA shows that the treatments created gradients in soil properties (Fig. 4.1). The plots with $\mathrm{CaCO}_{3}$ had clearly different soil properties compared to the other treatments, especially along the first principal component. The control and the $\mathrm{CaSO}_{4}, \mathrm{MgCO}_{3}$ and

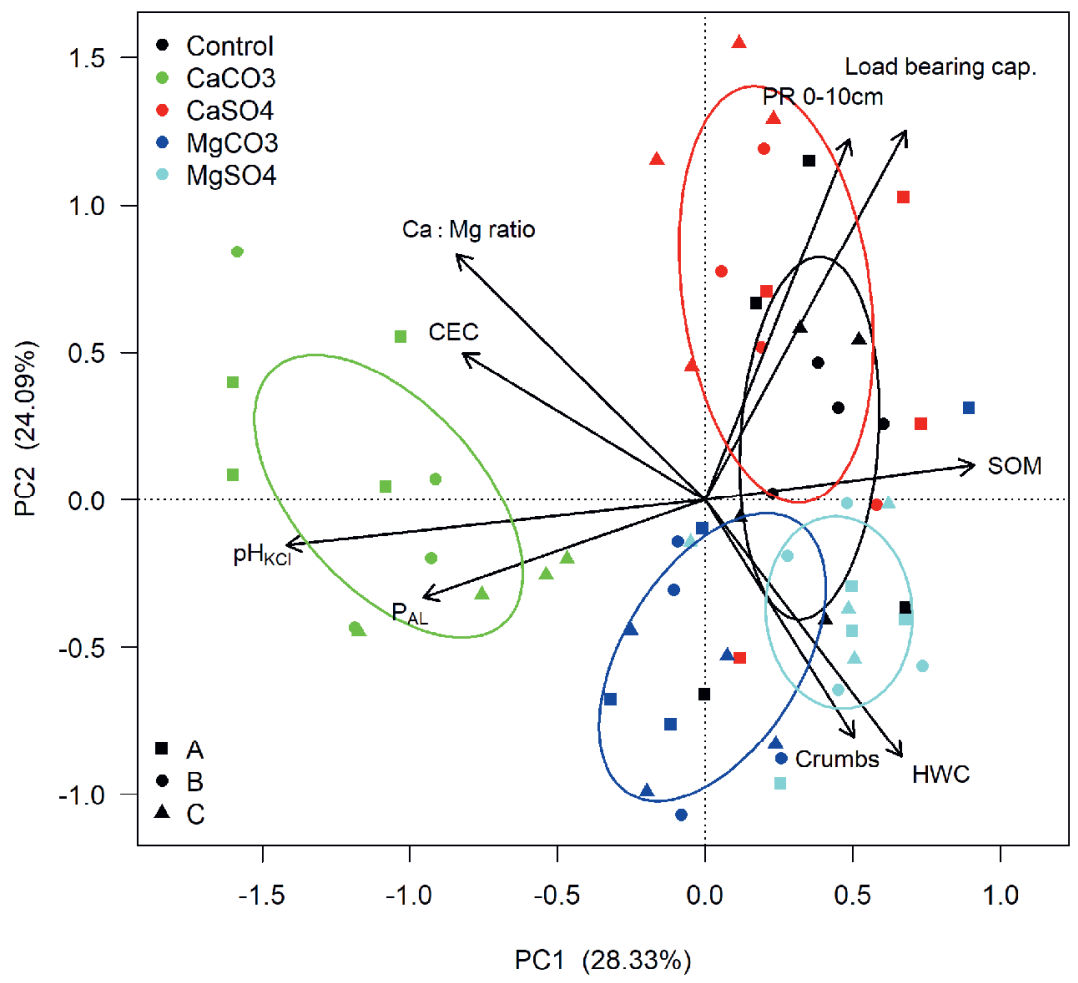

Figure 4.1 Axes 1 and 2 of a principal component analysis (PCA) of the residuals of soil chemical and physical parameters after conditioning for location and block. Treatments: Control, $\mathrm{CaCO}_{3}, \mathrm{CaSO}_{4}$, $\mathrm{MgCO}_{3}, \mathrm{MgSO}_{4}$; indicated with different colours. Locations: $\mathrm{A}, \mathrm{B}, \mathrm{C}$; indicated with different symbols. Ellipses per treatment with $50 \%$ confidence. PR: penetration resistance. Parameters were omitted from the figure when their arrows closely overlapped other arrows, indicating a strong mutual correlation in the two-dimensional plane of the two first principal components. This was the case for $\mathrm{N}_{\text {total }}, \mathrm{C}_{\text {total }}$ and $\mathrm{P}_{\text {total }}$ Overlapping SOM, and for PR $10-20 \mathrm{~cm}$ and PR $20-30 \mathrm{~cm}$ overlapping PR 0-10 $\mathrm{cm}$. 
$\mathrm{MgSO}_{4}$ treatments differed only in the second principal component. The two treatments with added $\mathrm{Mg}$ showed little mutual differences in soil parameters. Treatments with added $\mathrm{Ca}$ had higher $\mathrm{Ca}: \mathrm{Mg}$ ratio and CEC, and lower HWC and less crumb structures compared to those with added $\mathrm{Mg}$. Treatments with added $\mathrm{CO}_{3}$ had, or tended to have, higher $\mathrm{pH}_{\mathrm{KCl}}$ and lower SOM, $\mathrm{N}_{\text {total }}, \mathrm{C}_{\text {total }}$ and $\mathrm{P}_{\text {total }}$ compared to those with added $\mathrm{SO}_{4}$.

Many soil parameters differed between the three locations (Table S4.1) but showed no interaction between location and treatment (Table 4.2), meaning that for those parameters the location differences were not influencing the treatment effect. Soil $\mathrm{pH}_{\mathrm{KCl}}$ was significantly increased in treatments including $\mathrm{CO}_{3}$, compared to the control (Table 4.2), with a larger effect of $\mathrm{CaCO}_{3}$ than of $\mathrm{MgCO}_{3}$, whereas treatments with $\mathrm{SO}_{4}$ did not affect $\mathrm{pH}_{\mathrm{KCl}}$. $\mathrm{C}_{\text {total }}$ was decreased by the $\mathrm{CO}_{3}$ containing minerals, compared to the control, and the $\mathrm{SO}_{4}$ containing minerals had no effect. The amount of soil $\mathrm{CaCO}_{3}$ was negligible. $\mathrm{N}_{\text {total }}$ and $\mathrm{P}_{\mathrm{AL}}$ were only influenced by $\mathrm{CaCO}_{3}, \mathrm{~N}_{\text {total }}$ negatively and $\mathrm{P}_{\mathrm{AL}}$ positively. Load bearing capacity and penetration resistance in the $0-10 \mathrm{~cm}$ layer were increased by $\mathrm{CaSO}_{4}$. With $\mathrm{CO}_{3}$ containing minerals, the load bearing capacity and penetration resistance in the 0-10 cm layer were reduced. The percentage of crumbly soil elements and water infiltration rate were unaffected by treatments.

Table 4.2 Treatment effects for the soil chemical and physical properties not showing treatment $x$ location interaction ${ }^{*}$. $P$-values $\leq 0.05$ in bold. Means with the same superscript are not significantly different $(\alpha=0.05)$.

\begin{tabular}{|c|c|c|c|c|c|c|c|}
\hline Parameter & Unit & $P$-value & Control & $\mathrm{CaCO}_{3}$ & $\mathrm{CaSO}_{4}$ & $\mathrm{MgCO}_{3}$ & $\mathrm{MgSO}_{4}$ \\
\hline \multicolumn{8}{|l|}{ Soil chemical } \\
\hline CEC & Meq.100 $\mathrm{g}^{-1}$ & 0.037 & $20.9^{a}$ & $27.3^{b}$ & $23.1^{\mathrm{ab}}$ & $21.8^{\mathrm{a}}$ & $22.1^{\mathrm{a}}$ \\
\hline $\mathrm{pH}_{\mathrm{KCl}}$ & - & $<0.001$ & $4.7^{\mathrm{a}}$ & $6.1^{c}$ & $4.7^{\mathrm{a}}$ & $5.0^{b}$ & $4.8^{a}$ \\
\hline$C_{\text {total }}$ & g. $100 \mathrm{~g}^{-1}$ & 0.008 & $20.9^{b}$ & $20.5^{\mathrm{a}}$ & $21.1^{\mathrm{b}}$ & $20.4^{\mathrm{a}}$ & $21.1^{b}$ \\
\hline $\mathrm{N}_{\text {total }}$ & g. $100 \mathrm{~g}^{-1}$ & 0.006 & $1.70^{b}$ & $1.63^{\mathrm{a}}$ & $1.68^{b}$ & $1.67^{\mathrm{b}}$ & $1.69^{b}$ \\
\hline $\mathrm{P}_{\mathrm{AL}}$ & $\mathrm{mg} \mathrm{P} \mathrm{P}_{2} \mathrm{O}_{5} .100 \mathrm{~g}^{-1}$ & 0.002 & $45.1^{a}$ & $50.0^{b}$ & $43.6^{a}$ & $46.0^{a}$ & $45.1^{\mathrm{a}}$ \\
\hline \multicolumn{8}{|l|}{ Soil physical } \\
\hline Soil moisture & g. $100 \mathrm{~g}^{-1}$ & 0.006 & $52.1^{\mathrm{a}}$ & $52.5^{a b}$ & $53.1^{b c}$ & $52.3^{a}$ & $53.2^{c}$ \\
\hline Load bearing capacity & $\mathrm{N}$ & $<0.001$ & $235^{b c}$ & $211^{a}$ & $243^{c}$ & $207^{\mathrm{a}}$ & $217^{a b}$ \\
\hline Penetr. resistance $0-10 \mathrm{~cm}$ & $\mathrm{~N}$ & 0.006 & $112^{b c}$ & $105^{a b}$ & $118^{c}$ & $104^{a}$ & $110^{a b}$ \\
\hline Crumbs in $0-10 \mathrm{~cm}$ & g. $100 \mathrm{~g}^{-1}$ & 0.457 & 66.7 & 60.8 & 64.2 & 73.3 & 69.2 \\
\hline Water infiltration & $\mathrm{mm} \mathrm{min}-1$ & 0.615 & 3.5 & 2.5 & 3.1 & 2.9 & 2.4 \\
\hline
\end{tabular}

${ }^{*} P$-values of the treatment $\times$ location interaction were higher than 0.10 for all parameters in this table. Soil parameters with significant treatment $\times$ location interaction are presented in Fig. 4.2 and Table S4.3. 
The treatments showed a significant interaction with location for Ca:Mg, SOM, HWC, $P_{\text {total }}$ and penetration resistance in the 10-20 and 20-30 cm layers $(P<0.001, P=0.009$, 0.003, 0.034, 0.011 and 0.007, respectively: Fig. 4.2 and Table S4.3). At all sites Ca:Mg ratio was increased by Ca containing minerals (with little difference between $\mathrm{CaCO}_{3}$ and $\mathrm{CaSO}_{4}$ ), decreased by $\mathrm{Mg}$ containing minerals, and the effect of $\mathrm{MgCO}_{3}$ was smaller than that of $\mathrm{MgSO}_{4}$. The directions of the Ca:Mg effects were similar in the three locations, but the magnitudes were not: the effect of $\mathrm{Mg}$ containing minerals on the Ca:Mg ratio, as compared to the control, decreased with decreasing initial $\mathrm{Ca}: \mathrm{Mg}$ ratio, i.e. the $\mathrm{Ca}: \mathrm{Mg}$ ratio in the control plots. Differences in SOM were observed at location A between the two $\mathrm{Ca}$ containing minerals (lowest in $\mathrm{CaCO}_{3}$ ) and at location $\mathrm{C}$ between the two $\mathrm{Mg}$ containing minerals (lowest in $\mathrm{MgCO}_{3}$ ), whereas at location B no effect was measured. For HWC, the treatments with $\mathrm{Ca}$ had dissimilar effects depending on location: $\mathrm{CaCO}_{3}$ at location $\mathrm{A}$ led to a reduction compared to the control, no change at location $B$ and an increase at location C. The other minerals did not affect HWC, except for $\mathrm{CaSO}_{4}$ which increased HWC at location B. $\mathrm{P}_{\text {total }}$ was affected at location $\mathrm{A}$ only: in the $\mathrm{CaCO}_{3}$ and $\mathrm{MgSO}_{4}$ treatments a decrease was observed compared to the control.

Figure 4.2 (next page) Ca:Mg ratio, Soil organic matter, hot water extractable carbon (HWC) and $\mathrm{P}_{\text {total }}$ at the three locations, each showing significant location $\times$ treatment effects $(P<0.001, P=0.009,0.003$ and 0.034 , respectively). Within a location, bars with the same letter are not significantly different ( $\alpha$ $=5 \%)$. 

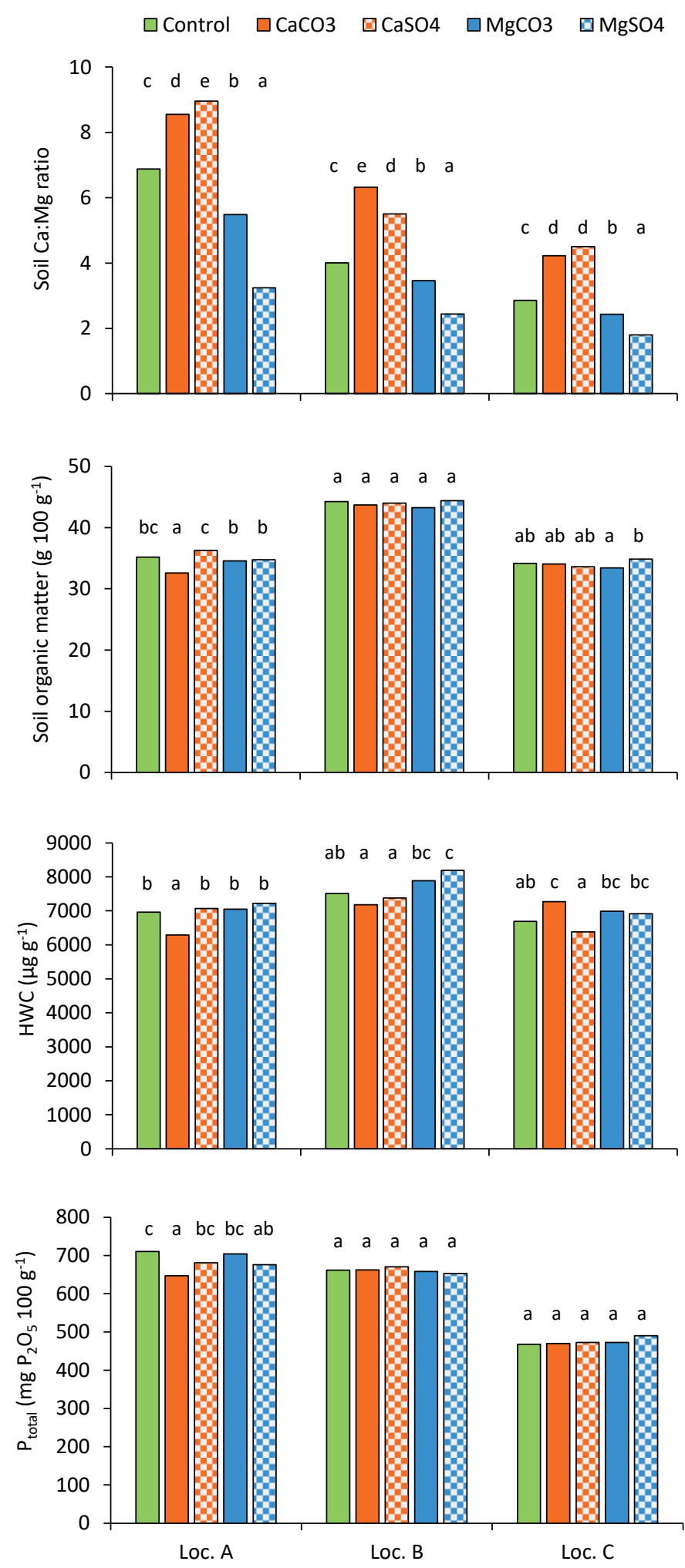
$\mathrm{MgCO}_{3}$ showed marginally suppressive treatment effects on mycorrhizal NLFA (Table 4.3). Other PLFA parameters were also lowest with $\mathrm{MgCO}_{3}$ but the differences were not significant. The stabilization of decomposition $(S)$ measured at location B with the tea bags index method was higher with $\mathrm{CaSO}_{4}$, indicating inhibition of the breakdown of organic matter, and lower with $\mathrm{MgCO}_{3}$. There was no significant effect on $k$.

Although the soil mineral $\mathrm{N}$ measured with PRS probes at location $\mathrm{B}$ was higher with $\mathrm{CaCO}_{3}$ application compared to the control during the three measuring periods, differences were not significant (Table 4.4). There was a significant gradual decrease in soil mineral $\mathrm{N}$ from week 1 to week 5 in both the control and the treated plots. This effect was determined by nitrate, as no effects were observed for ammonium.

Table 4.3 Treatment effects on soil microbiological (PLFA) and tea bag decomposition parameters measured at location $B$. Means with the same superscript are not significantly different $(\alpha=0.05)$. $P$ value $\leq 0.05$ in bold.

\begin{tabular}{|c|c|c|c|c|c|c|c|}
\hline Parameter & Unit & $P$-value & Control & $\mathrm{CaCO}_{3}$ & $\mathrm{CaSO}_{4}$ & $\mathrm{MgCO}_{3}$ & $\mathrm{MgSO}_{4}$ \\
\hline \multicolumn{8}{|l|}{ Soil microbiological } \\
\hline Microbial PLFA & $\mathrm{nmol} \mathrm{g}^{-1}$ & 0.170 & 72.2 & 78.7 & 67.2 & 54.1 & 75.7 \\
\hline Bacterial PLFA & $\mathrm{nmol} \mathrm{g}^{-1}$ & 0.176 & 39.2 & 43.4 & 37.1 & 30.0 & 41.2 \\
\hline Saprotrophic fungal PLFA & $\mathrm{nmol} \mathrm{g}^{-1}$ & 0.563 & 0.91 & 0.99 & 0.93 & 0.66 & 0.92 \\
\hline AMF NLFA & $\mathrm{nmol} \mathrm{g}{ }^{-1}$ & 0.058 & 0.65 & 0.57 & 0.79 & 0.32 & 0.57 \\
\hline Actinomycetes PLFA & $\mathrm{nmol} \mathrm{g}{ }^{-1}$ & 0.171 & 4.05 & 4.24 & 3.72 & 2.53 & 3.99 \\
\hline Gram-positive PLFA & $\mathrm{nmol} \mathrm{g}{ }^{-1}$ & 0.178 & 24.2 & 26.8 & 24.6 & 19.0 & 26.2 \\
\hline Gram-negative PLFA & $\mathrm{nmol} \mathrm{g}{ }^{-1}$ & 0.224 & 5.50 & 5.57 & 4.82 & 3.83 & 5.52 \\
\hline \multicolumn{8}{|l|}{ Tea bag indices } \\
\hline Stabilization factor $(S)$ & - & 0.003 & $0.25^{b}$ & $0.24^{a b}$ & $0.27^{c}$ & $0.23^{a}$ & $0.25^{b}$ \\
\hline Decomposition rate $(k)$ & - & 0.137 & 0.014 & 0.013 & 0.016 & 0.014 & 0.017 \\
\hline
\end{tabular}

Table 4.4 Effects of $\mathrm{CaCO}_{3}$ application and week of measurement after the first cut in 2016 on the availability of mineral $\mathrm{N}$ in the soil $\left(\mathrm{mg} \mathrm{m}^{-2} \mathrm{wk}^{-1}\right)$ measured with PRS probes at location $\mathrm{B}$. $P$-values $\leq$ 0.05 in bold.

\begin{tabular}{|c|c|c|c|c|c|c|c|c|c|}
\hline \multirow[b]{2}{*}{ Parameter } & \multicolumn{2}{|c|}{ Week 1} & \multicolumn{2}{|c|}{ Week 3} & \multicolumn{2}{|c|}{ Week 5} & \multicolumn{3}{|c|}{$P$-value ${ }^{+}$} \\
\hline & Control & $\mathrm{CaCO}_{3}$ & Control & $\mathrm{CaCO}_{3}$ & Control & $\mathrm{CaCO}_{3}$ & $T$ & W & $\mathrm{T} \times \mathrm{W}$ \\
\hline Total mineral N & 41.4 & 50.8 & 20.7 & 36.5 & 11.8 & 13.4 & 0.275 & 0.032 & 0.610 \\
\hline $\mathrm{NO}_{3}-\mathrm{N}$ & 38.6 & 49.5 & 19.2 & 35.0 & 7.5 & 11.2 & 0.206 & 0.024 & 0.659 \\
\hline $\mathrm{NH}_{4}-\mathrm{N}$ & 2.8 & 1.4 & 1.5 & 1.4 & 4.3 & 2.2 & 0.198 & 0.202 & 0.479 \\
\hline
\end{tabular}

${ }^{\dagger} \mathrm{T}$ : treatment, W: week 


\subsubsection{Grass $\mathbf{N}$ yield}

Grass $\mathrm{N}$ yield of the control plots, cumulated over 4 cuts per year, varied between $180 \mathrm{~kg}$ $\mathrm{N} \mathrm{ha}^{-1}$ (location C) and $221 \mathrm{~kg} \mathrm{~N} \mathrm{ha}^{-1}$ (B) in 2015 and between $198 \mathrm{~kg} \mathrm{~N} \mathrm{ha}^{-1}$ (B) and $246 \mathrm{~kg}$ $\mathrm{N} \mathrm{ha}^{-1}(\mathrm{~A})$ and was influenced by treatments. There was a location $\times$ treatment interaction in $2015(P=0.016)$ and a main treatment effect in $2016(P<0.001)$ without interaction with location ( $P=0.130$ ) (Fig. 4.3). In 2015, location $\mathrm{A}$ had similar $\mathrm{N}$ yield with both $\mathrm{CO}_{3}$ minerals compared to the control but lower $\mathrm{N}$ yield with both $\mathrm{SO}_{4}$ minerals. In locations $\mathrm{B}$ and $\mathrm{C}$, positive effects of $\mathrm{CaCO}_{3}$ but no effects of the other minerals were found in 2015 . In 2016, in all locations, differences between treatments were similar to those found in 2015 at location $\mathrm{A}$ : similar $\mathrm{N}$ yield with $\mathrm{CaCO}_{3}$ and $\mathrm{MgCO}_{3}$ compared to the control but lower $\mathrm{N}$ yield with $\mathrm{CaSO}_{4}$ or $\mathrm{MgSO}_{4}$.
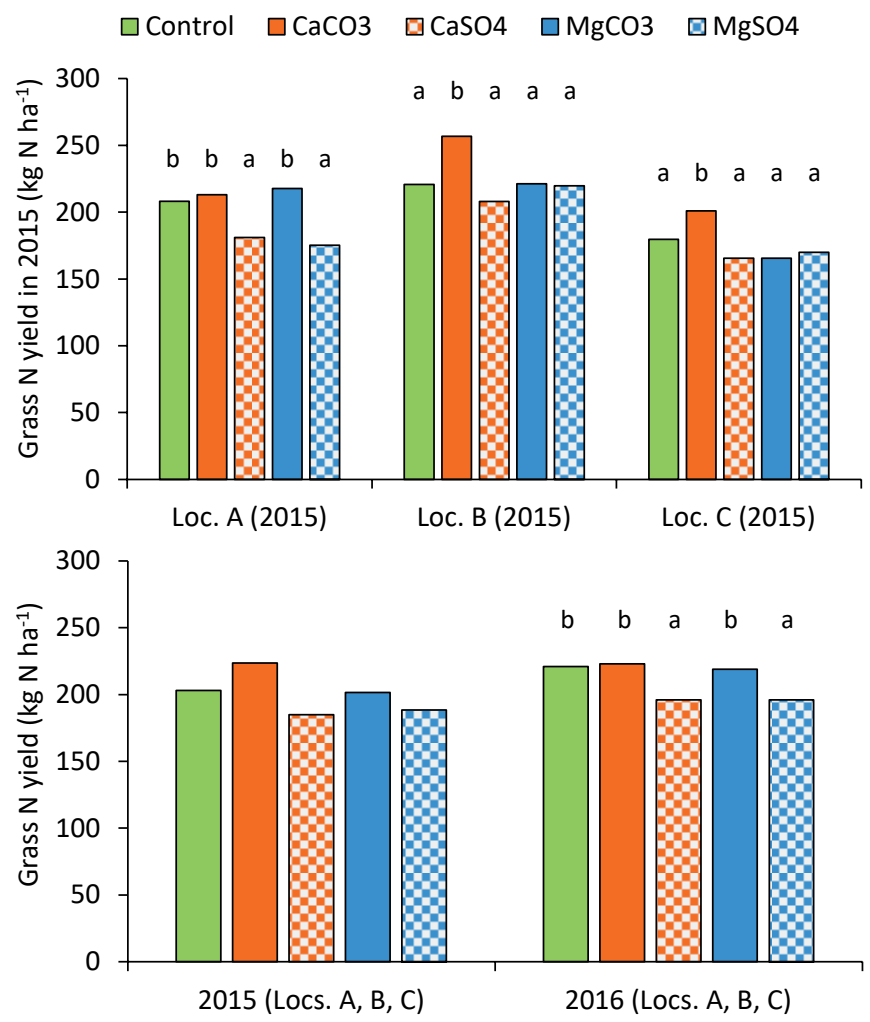

Figure 4.3 Grass N yield $\left(\mathrm{kg} \mathrm{N} \mathrm{ha}^{-1}\right)$ in 2015 per location (above; significant location $\times$ treatment effect, $P=0.016$ ) and in 2015 and 2016 over the three locations (below; for 2016: $P=0.130$ for location $\times$ treatment effect and $P<0.001$ for treatment effect). In location C, 2015, grass $N$ yield does not include the $2^{\text {nd }}$ cut (see Methods). Within a location (above - 2015) or year (below - 2016), bars with the same letter are not significantly different $(\alpha=5 \%)$. 
Grass N yield per individual cut over the years 2015 and 2016 showed significant treatment effects from the second half of 2015 onwards (Fig. 4.4). The plots treated with $\mathrm{CaCO}_{3}$ had higher $\mathrm{N}$ yields than the control in the last two cuts of 2015 , but no such effect was observed in 2016. In the plots treated with $\mathrm{CaSO}_{4}$, a negative effect appeared in the last cut of 2015, continued in the first cuts of 2016 but recovered to the level of the control at the end of 2016.

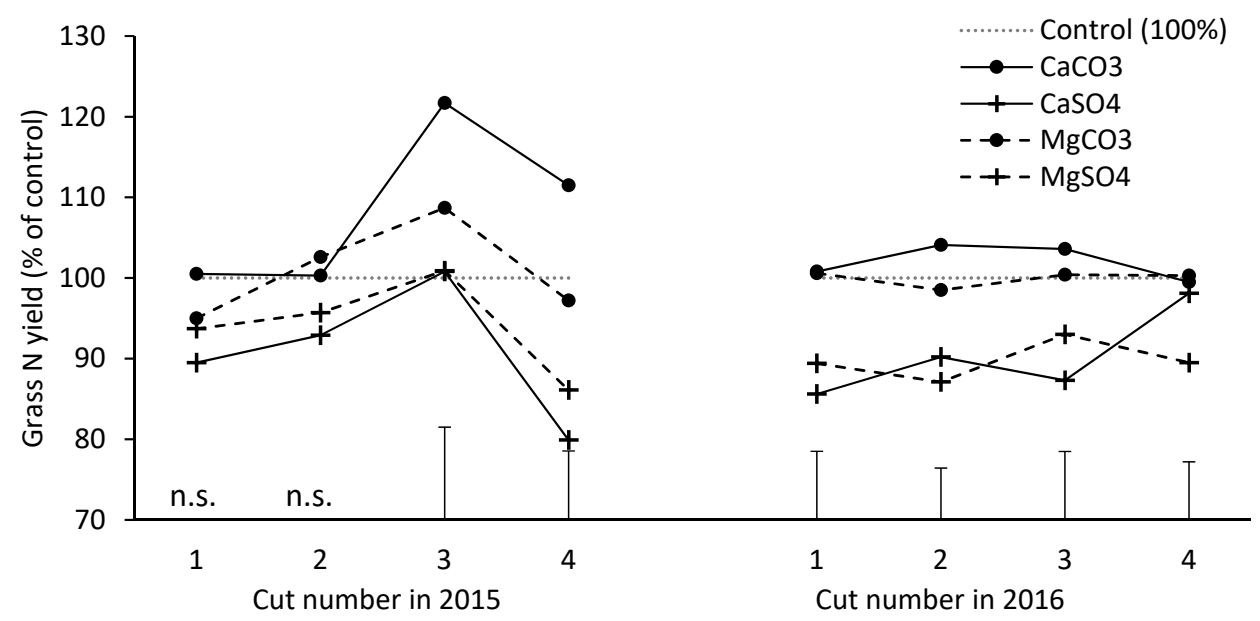

Figure 4.4 Grass N yield $\left(\mathrm{kg} \mathrm{N} \mathrm{ha}^{-1}\right.$ ) per cut in 2015 and 2016, expressed as a percentage of the control plots. Means of three locations and four replicates. Vertical bars on the $x$-axis represent the I.s.d. per cut in case of significant $(P \leq 0.05)$ treatment effect. Mean values of the control plots for each consecutive cut (1 to 4) are 72, 44, 62 and $40 \mathrm{~kg} \mathrm{~N} \mathrm{ha}^{-1}$ in 2015 and 76, 57, 45 and $43 \mathrm{~kg} \mathrm{~N} \mathrm{ha}^{-1}$ in 2016.

\subsubsection{Regression analysis with grass $\mathbf{N}$ yield and soil properties}

The regression analysis linking grass N yield in 2015 and 2016 with soil properties measured in October 2015 resulted in a number of explanatory models (Table 4.5). Cumulative $\mathrm{N}$ yield per year was explained in 2015 but not in 2016. Per grass cut, significant models were found in 2015 for cuts 3 and 4 and in 2016 for cuts 1 and 2. In most models for the three locations together, $\mathrm{pH}_{\mathrm{KCl}}$ was the first selected explanatory parameter, followed by $\mathrm{P}_{\mathrm{AL}}$ or CEC. For cut 1 of 2016, $\mathrm{C}_{\text {total }}$ was the first selected explanatory parameter. Only in one specific model (cut 2 in 2016) a marginal contribution of Ca:Mg ratio to grass $\mathrm{N}$ yield was found. In location $\mathrm{A}, \mathrm{P}_{\text {total }}$ best explained the variation in grass $\mathrm{N}$ yield for the first cut of 2016 . No significant models were found for locations $B$ or C in either 2015 or 2016. 
Table 4.5 Soil parameters that significantly $(P \leq 0.05)$ explain the variation in grass $\mathrm{N}$ yield after addition of $\mathrm{CaCO}_{3}, \mathrm{CaSO}_{4}, \mathrm{MgCO}_{3}, \mathrm{MgSO}_{4}$ or no mineral. The explanatory parameters considered are mentioned in Table S4.1. Explanatory parameters from a regression model were included with a forward selection procedure, which was only run on significant $(P \leq 0.05)$ models. Alternative simpler models are presented if also significant (see Methods for details).

\begin{tabular}{|c|c|c|c|c|}
\hline Location(s) & $\begin{array}{l}\text { Dependent } \\
\text { parameter } \\
\text { ( } \mathrm{N} \text { yield) }\end{array}$ & $\begin{array}{l}\text { Removed from } \\
\text { explanatory } \\
\text { data }\end{array}$ & $r^{2}$ adj & $\begin{array}{l}\text { Explanatory parameter(s) (partial } r^{2}{ }_{\text {adj }} \text { in } \\
\text { brackets) }{ }^{\ddagger}\end{array}$ \\
\hline \multirow[t]{2}{*}{$A, B, C$} & 2015: year total & - & 0.55 & $\mathrm{pH}_{\mathrm{KCl}}(0.33), \mathrm{P}_{\text {total }}(0.04), \mathrm{C}_{\text {total }}(0.12), \mathrm{N}_{\text {total }}(0.06)$ \\
\hline & & $\mathrm{pH}_{\mathrm{KCl}}$ & 0.23 & $\mathrm{P}_{\mathrm{AL}}(0.22), \mathrm{C}_{\text {total }}(0.09)$ \\
\hline$A, B, C$ & 2015: cut 1 & - & - & n.s. \\
\hline$A, B^{+}$ & 2015: cut 2 & - & - & n.s. \\
\hline \multirow[t]{2}{*}{$A, B, C$} & 2015: cut 3 & - & 0.32 & $\mathrm{pH}_{\mathrm{KCI}}(0.16)$, Crumbs $(0.11), \mathrm{C}_{\text {total }}(0.05)$ \\
\hline & & $\mathrm{pH}_{\mathrm{KCl}}$ & 0.27 & $\begin{array}{l}\text { CEC (0.07), } P_{A L}(0.07), C_{\text {total }}(0.05) \text {, Crumbs }(0.05) \text {, } \\
\text { PR 0-10cm }\end{array}$ \\
\hline$A, B, C$ & 2015: cut 4 & - & 0.18 & $\mathrm{pH}_{\mathrm{KCl}}(0.28), \mathrm{P}_{\text {total }}(-0.01), \mathrm{PR} 10-20 \mathrm{~cm}(-0.01)$ \\
\hline$A, B, C$ & 2016: year total & - & - & n.s. \\
\hline \multirow[t]{2}{*}{$A, B, C$} & 2016: cut 1 & - & 0.25 & $C_{\text {total }}(0.07)$, PR $0-10 \mathrm{~cm}(0.06)$ \\
\hline & & $C_{\text {total }}$ & 0.13 & $\mathrm{pH}_{\mathrm{KCl}}$ \\
\hline \multirow[t]{2}{*}{$A, B, C$} & 2016: cut 2 & - & 0.55 & $\mathrm{pH}_{\mathrm{KCI}}(0.32), \mathrm{N}_{\text {total }}(0.11)$ \\
\hline & & $\mathrm{pH}_{\mathrm{KCl}}$ & 0.08 & $\mathrm{P}_{\mathrm{AL}}(0.10), \mathrm{Ca}: \mathrm{Mg}$ ratio $(0.07), \mathrm{PR} 20-30 \mathrm{~cm}(0.05)$ \\
\hline$A, B, C$ & 2016: cut 3 & - & - & n.s. \\
\hline$A, B, C$ & 2016: cut 4 & - & - & n.s. \\
\hline A & 2016: cut 1 & - & 0.75 & $P_{\text {total }}(0.82), \mathrm{HWC}(0.32), \mathrm{CEC}(0.18)$ \\
\hline B & (none significant) & & & \\
\hline C & (none significant) & & & \\
\hline
\end{tabular}

${ }^{\dagger} \mathrm{N}$ yield data missing for location $\mathrm{C}$.

${ }^{\ddagger}$ PR: Penetration resistance.

\subsection{Discussion}

\subsubsection{Effects of treatments on grass $\mathbf{N}$ yield}

A considerable range of soil Ca:Mg ratios was created by the treatments and grass $\mathrm{N}$ yield was increased or reduced depending on treatment, location and year (Figs. 4.3 and 4.4). However, changes in Ca:Mg ratio (Fig. 4.2) did not correspond to changes in grass $\mathrm{N}$ yield (Fig. 4.3). Instead, $\mathrm{pH}_{\mathrm{KCl}}$ and to a lesser extent $\mathrm{P}_{\mathrm{AL}}$ and $\mathrm{CEC}$ were selected in the regression procedure as explanatory variables for the variation in grass $\mathrm{N}$ yield (Table 4.5). 
Our first hypothesis, that grass $\mathrm{N}$ yield would be positively correlated with soil Ca:Mg ratio, was based on a correlative field study (Deru et al., 2019) but did not stand the factorial experimental test: grass $\mathrm{N}$ showed clear treatment effects that were primarily grouped per anion $\left(\mathrm{CO}_{3}\right.$ or $\left.\mathrm{SO}_{4}\right)$ and less per cation (Ca or $\mathrm{Mg}$ ) (Fig. 4.3). Interestingly, the effects tended to decrease during the course of the experiment (Fig. 4.4). Haynes and Naidu (1998) described influences of $\mathrm{CaCO}_{3}$ on soil properties as a short-term effect $(\approx 1$ $\mathrm{yr}$ ) of higher $\mathrm{pH}$ on soil microbiological activity, SOM decomposition and $\mathrm{N}$ mineralization, and of higher Ca concentration on soil structure versus long-term indirect effects (i.e. >10 yrs) on SOM via increased crop growth. Indeed, $\mathrm{pH}$ was the most important predictor of $\mathrm{N}$ yield in our experiment (Table 4.5). In acid soils, a positive effect of liming and increased $\mathrm{pH}$ on grass yield is assumed to be caused by increased $\mathrm{N}$ mineralization and $\mathrm{P}$ availability as a result of increased microbial activity (although effects may be temporary as discussed above), combined with reduced aluminium toxicity (Bolan et al., 2003; Haynes, 1984; Haynes and Naidu, 1998; Murphy, 2007). In our soils, aluminium concentrations were very low ( $<0.5 \%$ of CEC and no treatment effect), but in line with the above literature, the higher $\mathrm{P}_{\mathrm{AL}}$ concentration in soil after addition of $\mathrm{CaCO}_{3}$ (Table 4.2), the selection of both $\mathrm{P}_{\mathrm{AL}}$ and $\mathrm{pH}_{\mathrm{KCl}}$ for the models explaining grass $\mathrm{N}$ yield (Table 4.5 ) and the higher $\mathrm{N}$ content in the grass in 2015 (Table S4.4) indicate a pH effect via enhanced $\mathrm{N}$ and P mineralization. Moreover, this effect tended to decrease from 2015 to 2016 (Figs. 4.3 and 4.4; Table S4.4) or was not shown by the soil mineral $\mathrm{N}$ contents in 2016 (Table 4.4). Hence, these observations may explain the different outcome of the present study compared to Deru et al. (2019), indicating mainly short-term soil chemical effects on herbage yield that may have masked possible longer term $\mathrm{Ca}: \mathrm{Mg}$ ratio effects via soil physical properties (Dontsova and Norton, 2002). In contrast, the study of Deru et al. (2019) was based on grasslands with a stable management and no liming for at least five years, thus where differences in soil Ca:Mg ratio were likely to originate from soil type and longer term management history. So, within the time-span of the present study, no evidence was found for our second hypothesis, that Ca:Mg effects would be caused by changes in soil physical properties rather than in $\mathrm{N}$ mineralization.

In 2015 a higher $\mathrm{N}$ yield and $\mathrm{pH}$ were measured with the addition of $\mathrm{CaCO}_{3}$, whereas a reduced $\mathrm{N}$ yield was found with minerals containing $\mathrm{SO}_{4}$ in 2015 (location $\mathrm{A}$ ) and 2016 (all locations). Our measurements do not provide a clear explanation for these effects of $\mathrm{SO}_{4}$ (Table 4.5). Increased exchangeable Ca concentration and higher ionic strength of the 
soil solution in acid mineral soils treated with gypsum $\left(\mathrm{CaSO}_{4}\right)$ is normally found to increase clay flocculation and reduce penetration resistance and aluminium toxicity, generally leading to better water infiltration, deeper rooting and higher crop yield (Shainberg et al., 1989; Sumner et al., 1990). The higher penetration resistance and generally lower grass yields (Fig. 4.3; Fig. S4.2) in our experiment are therefore unexpected. Peat soils have very different physical properties than mineral soils (Schwärzel et al., 2002; Sognnes et al., 2006) and addition of gypsum $\left(\mathrm{CaSO}_{4}\right)$ has been found to increase peat stability (Kolay and

Pui, 2010; Saberian and Rahgozar, 2016). In our experiment, this effect may possibly have resulted in modified soil physical properties with higher penetration resistance negatively influencing grass growth.

\subsubsection{Effects of treatments on soil properties}

$\mathrm{C}_{\text {total }}$ and $\mathrm{N}_{\text {total }}$ were similarly influenced per treatment at each location, whereas SOM and HWC showed a significant interaction with location. This indicates that mineralization was affected by the added minerals but also by local edaphic properties.

The changes in $\mathrm{C}_{\text {total }}$ observed in the top $10 \mathrm{~cm}$ soil layer after addition of $\mathrm{CaCO}_{3}$ or $\mathrm{MgCO}_{3}$ in October 2015 are equivalent to a loss of $2.8 \mathrm{Mg} \mathrm{C} \mathrm{ha}^{-1}$ in comparison with the control (with a bulk density of $0.54 \mathrm{~g} \mathrm{~cm}^{-3}$ measured in the same soil type and region in dairy grasslands (Deru et al., 2018a)). Estimates of the background $\mathrm{CO}_{2}$ emission from drained peat grasslands in the Netherlands range between 2.2 and $5.8 \mathrm{MgCha}^{-1} \mathrm{yr}^{-1}$ from the whole peat layer (Jacobs et al., 2007; Van den Akker et al., 2008). Thus, $\mathrm{CO}_{3}$ liming increased the peat decomposition rate substantially, at least during the first two years.

$\mathrm{C}_{\text {total }}$ was similarly reduced by the application of $\mathrm{CaCO}_{3}$ and $\mathrm{MgCO}_{3}$ despite the higher application rate of $\mathrm{CO}_{3}$ in the $\mathrm{CaCO}_{3}$ treatment and the stronger $\mathrm{pH}$ increase (Tables 4.1 and 4.2). An assumed effect of enhanced microbial respiration by increased $\mathrm{pH}$ does therefore not provide a sufficient explanation for the similar effects on $\mathrm{C}_{\text {total }}$ In soil, $\mathrm{Ca}$ ions can stabilize organic matter by Ca binding (Rowley et al., 2018), thereby reducing microbial respiration and mineralization. This may have occurred in the $\mathrm{CaCO}_{3}$ treatment, in contrast to the treatment with $\mathrm{MgCO}_{3}$ which possibly explains the similar reduction of $\mathrm{C}_{\text {total }}$ in both treatments despite the higher application rate of $\mathrm{CO}_{3}$ in the $\mathrm{CaCO} 3$ treatment and the stronger $\mathrm{pH}$ increase. 
$\mathrm{C}_{\text {total }}$ was not influenced by $\mathrm{SO}_{4}$ containing minerals, which confirms that it was the addition of the $\mathrm{CO}_{3}$ in the $\mathrm{CaCO}_{3}$ and $\mathrm{MgCO}_{3}$ treatments that primarily caused its reduction. However, $\mathrm{SO}_{4}$ may leach to the deeper anoxic peat layers and act as alternative electron acceptor, enhancing the decomposition of organic matter and initiating internal eutrophication in deeper layers (Smolders et al., 2006). Although the microbial decomposition processes involved are likely to be much slower than those in the oxic peat layer, addition of $\mathrm{SO}_{4}$ to drained peat grasslands is not advisable, and should at least be evaluated in the longer term and in the whole peat layer.

The amount of soil $\mathrm{C}$ is determined by the balance between decomposition and inputs, which complicates the interpretation of results simply based on differences in $\mathrm{C}$ concentration between treatments. In our experiment, differences in $\mathrm{N}_{\text {total, }}$, however, can be primarily attributed to $\mathrm{N}$ mineralization, as $\mathrm{N}$ deposition (c. $30 \mathrm{~kg} \mathrm{ha}^{-1} \mathrm{yr}^{-1}$ in the Netherlands) was the same in all treatments and no further substantial $\mathrm{N}$ input source such as legumes was present. Assuming no changes in soil bulk density, our results show a clear positive effect of $\mathrm{CaCO}_{3}$ on $\mathrm{N}$ mineralization (lower $\mathrm{N}_{\text {total }}$ ) whereas the other treatments had no effects. Compared to the control, a decrease in $\mathrm{N}_{\text {total }}$ equivalent to 380 $\mathrm{kg} \mathrm{N} \mathrm{ha}{ }^{-1}$ was measured in the $\mathrm{CaCO}_{3}$ treatment. Of this amount, only $21 \mathrm{~kg}$ was recovered as additional grass $\mathrm{N}$ yield in the $\mathrm{CaCO}_{3}$ treatment compared to the control during that year. This would imply that nearly all $\mathrm{N}$ mineralized during the 1.5 years following the first addition of $\mathrm{CaCO}_{3}$ was either emitted as $\mathrm{N}_{2} \mathrm{O}$ or $\mathrm{N}_{2}$, or leached as $\mathrm{NO}_{3}$ to deeper layers. $\mathrm{NO}_{3}$ in anoxic peat layers can act as an electron acceptor similarly to $\mathrm{SO}_{4}$, as discussed above.

SOM and HWC, being both organic matter fractions, showed a significant interaction of treatment with location, suggesting that organic matter breakdown or build-up processes were different per location. The three experimental locations differed not only in Ca: $\mathrm{Mg}$ ratio $(\mathrm{A}>\mathrm{B}>\mathrm{C})$, but also in soil $\mathrm{P}$ availability $(\mathrm{A}>\mathrm{B}>\mathrm{C}$; Table S4.1). For treatment effects in SOM and HWC (Fig. 4.2) we propose tentative explanations based on literature showing that decomposition of organic matter (in our case SOM and HWC) is $\mathrm{pH}$ dependent (Fernández-Calviño and Bååth, 2010; Ghani et al., 2003), but may also be hampered under P limitation (Amador and Jones, 1993; Brouns et al., 2016; Cheshire and Chapman, 1996) and reduced by Ca binding (Rowley et al., 2018), and finally that the concentration of soluble $\mathrm{C}$ (such as HWC) is increased at higher $\mathrm{pH}$ due to microbial and chemical dissolution of SOM, and reduced by addition of Ca (Andersson and Nilsson, 2001; 
Oste et al., 2002). Firstly, in location A, lower SOM and $\mathrm{HWC}$ in the treatment with $\mathrm{CaCO}_{3}$ is explained by the higher $\mathrm{pH}$ resulting in faster decomposition of SOM and HWC, outweighing binding effects of added $\mathrm{Ca}$. The proportionally similar decrease in $\mathrm{P}_{\text {total }}$ (Fig. 4.2) points in the same direction. Secondly, in location $C$, the low soil $P$ availability may have limited the effect of higher $\mathrm{pH}$ (by addition of $\mathrm{CaCO}_{3}$ ) on organic matter decomposition, resulting in no change in SOM but an increase in HWC due to increased dissolution of SOM at higher $\mathrm{pH}$. Lastly, in locations B and C, Ca binding after addition of $\mathrm{CaSO}_{4}$ may have reduced the solubility of organic compounds, without interference of changed $\mathrm{pH}$, which was reflected by a lower $\mathrm{HWC}$ when compared to $\mathrm{MgSO}_{4}$ (Fig. 4.2). In location $\mathrm{B}$, the changes in tea bag stabilization index $(S)$ (lower with $\mathrm{CaCO}_{3}$, higher with $\mathrm{CaSO}_{4}$; Table 4.3) also indicate that an increased soil Ca concentration without change in $\mathrm{pH}$ (by application of $\mathrm{CaSO}_{4}$ ) reduces the (potential) breakdown of organic matter. The above supports our third hypothesis that $\mathrm{CO}_{3}$ addition increases $\mathrm{pH}, \mathrm{SOM}$ decomposition, and grass $\mathrm{N}$ yield independent of the Ca:Mg ratio. However, we show that location differences in soil $\mathrm{P}$ availability partly determine the effects of added minerals and that $\mathrm{Ca}$ binding may reduce the concentration of soluble SOM compounds and decomposition. Therefore, the agricultural advice for an optimal $\mathrm{pH}$ and use of liming minerals in peat grasslands should be revised based on field experiments in a larger number of grasslands to better represent the variation in edaphic conditions within this soil type.

\subsection{Conclusions and recommendations}

Addition of $\mathrm{Ca}$ and $\mathrm{Mg}$ containing minerals in peat grasslands influenced the SOM dynamics and the soil chemical and physical properties and this was especially true for $\mathrm{CaCO}_{3}$. Contrary to our first hypothesis that was based on a previous correlative study in twenty dairy grasslands on peat, grass $\mathrm{N}$ yield was primarily linked with changes in soil $\mathrm{pH}$ and not with changes in $\mathrm{Ca}: \mathrm{Mg}$ ratio.

Of the applied minerals, $\mathrm{CaCO}_{3}$ had the largest influence on grass $\mathrm{N}$ yield, and increased also $\mathrm{pH}$ and (indicators of) SOM decomposition without evidence for our second hypothesis that grass $\mathrm{N}$ yield would correlate with soil physical properties. Grass $\mathrm{N}$ yield increased one year after applying the $\mathrm{CaCO}_{3}$ mineral, but the coinciding strong decrease in the soil $\mathrm{N}$ stock indicated low utilization of the (extra) mineralized $\mathrm{N}$. The decrease in soil $\mathrm{C}_{\text {total }}$ was of the same order of magnitude as the background $\mathrm{CO}_{2}-\mathrm{C}$ emission from 
drained peat grasslands. The minerals containing $\mathrm{SO}_{4}$ reduced grass $\mathrm{N}$ yield in most cuts and $\mathrm{CaSO}_{4}$ application increased soil penetration resistance below the $10 \mathrm{~cm}$ topsoil. Thus, during the first two years after the experimental manipulation of the soil Ca:Mg ratio, effects of added minerals were more determined by the anions $\left(\mathrm{CO}_{3}\right.$ or $\left.\mathrm{SO}_{4}\right)$ than by the cations ( $\mathrm{Ca}$ or $\mathrm{Mg}$ ). As cation effects may appear in the longer term, we recommend measurements over a longer period. Our results further show that accelerated SOM decomposition after $\mathrm{CaCO}_{3}$ application was mainly related to increased $\mathrm{pH}$, as hypothesized. However, in soils with low P availability, SOM was not decreased even at higher $\mathrm{pH}$, possibly due to $\mathrm{P}$ limited microbial activity. Moreover, in the treatment with added $\mathrm{Ca}$ but without pH-effect $\left(\mathrm{CaSO}_{4}\right)$, lower $\mathrm{HWC}$ and a higher teabag stabilization factor suggested a stabilization of organic matter by Ca binding.

The results of our experiment do not support Ca:Mg ratio as a useful measure of soil quality for increased herbage production in peat grasslands without extra SOM mineralization and losses of $\mathrm{C}$ and $\mathrm{N}$. To avoid those losses, the agricultural $\mathrm{pH}$ advice for peat grasslands should be better adapted to the local soil properties that influence SOM decomposition and be more specific in the type of mineral to use.

\section{Acknowledgements}

We thank the farmers Anton de Wit, Jan Graveland and Richard Korrel for providing us the opportunity to carry out experiments on their grasslands. Frank Lenssinck, Bart Vromans and Sjoerd Smits are acknowledged for their contributions to the project and the experimental setup and Arjan Reijneveld for additional soil analyses. We thank Coen ter Berg, Riekje Bruinenberg, Hans Dullaert, René Groenen, Hannah te Velde and Karel van Houwelingen for assistance in field work, An Vos, Wim Dimmers, Jan Bovenschen and Arrienne Matser for analysing HWC and PLFA, and Sabine Schnabel and Paul Keizer for statistical advise.

\section{Funding}

This work was part of the projects "Bodemindicatoren voor duurzaam bodemgebruik in de veenweiden" and "Proeftuin Veenweiden". These projects were funded by Stichting Kennisontwikkeling en kennisoverdracht Bodem, the Provinces Noord-Holland, Zuid- 
Holland and Utrecht, the Dutch Ministry of Infrastructure and Water Management, the Dutch Ministry of Agriculture, Nature and Food Quality, the Dairy Board (ZuivelNL), LTO Noord Fondsen, WUR Environmental Research and the Foundation for Applied Water Research (STOWA). 


\section{Appendix: Supplementary material}

Table S4.1 Soil properties in the control plots at the three locations in October 2015. Means with the same superscript are not significantly different $(\alpha=0.05)$.

\begin{tabular}{|c|c|c|c|c|c|}
\hline \multirow[b]{2}{*}{ Parameter } & \multirow[b]{2}{*}{ Unit } & \multicolumn{3}{|c|}{ Location (control plots) } & \multirow[b]{2}{*}{ Sign. $^{+}$} \\
\hline & & A & $B$ & $\bar{C}$ & \\
\hline \multicolumn{6}{|l|}{ Soil chemical } \\
\hline CEC & meq. $100 \mathrm{~g}^{-1}$ & $22.4^{\mathrm{b}}$ & $23.6^{\mathrm{b}}$ & $16.6^{\mathrm{a}}$ & * \\
\hline Ca:Mg ratio & - & $6.9^{c}$ & $4.0^{b}$ & $2.9^{a}$ & $* * *$ \\
\hline $\mathrm{pH}_{\mathrm{KCl}}$ & - & $4.8^{b}$ & $4.9^{c}$ & $4.5^{\mathrm{a}}$ & $* * *$ \\
\hline SOM & g. $100 \mathrm{~g}^{-1}$ & $35.2^{\mathrm{a}}$ & $44.3^{b}$ & $34.2^{a}$ & $* * *$ \\
\hline$C_{\text {total }}$ & g. $100 \mathrm{~g}^{-1}$ & $19.6^{\mathrm{a}}$ & $24.3^{b}$ & $19.0^{\mathrm{a}}$ & $* * *$ \\
\hline HWC & $\mu g$ C. $g^{-1}$ & 6964 & 7510 & 6689 & n.s. \\
\hline $\mathrm{N}_{\text {total }}$ & g. $100 \mathrm{~g}^{-1}$ & $1.68^{\mathrm{b}}$ & $2.00^{c}$ & $1.43^{a}$ & $* * *$ \\
\hline$P_{\text {total }}$ & $\mathrm{g} \mathrm{P}_{2} \mathrm{O}_{5} .100 \mathrm{~g}^{-1}$ & $0.71^{c}$ & $0.66^{b}$ & $0.47^{\mathrm{a}}$ & $* * *$ \\
\hline $\mathrm{P}_{\mathrm{AL}}$ & $\mathrm{mg} \mathrm{P}_{2} \mathrm{O}_{5} .100 \mathrm{~g}^{-1}$ & $67.2^{c}$ & $45.5^{b}$ & $22.5^{a}$ & $* * *$ \\
\hline \multicolumn{6}{|l|}{ Soil physical } \\
\hline Load bearing capacity & $\mathrm{N}$ & $265^{b}$ & $273^{b}$ & $168^{\mathrm{a}}$ & $* * *$ \\
\hline Penetration resistance $0-10 \mathrm{~cm}$ & $\mathrm{~N}$ & $138^{c}$ & $110^{\mathrm{b}}$ & $89^{a}$ & $* * *$ \\
\hline Penetration resistance $10-20 \mathrm{~cm}$ & $\mathrm{~N}$ & $154^{b}$ & $142^{a b}$ & $129^{\text {a }}$ & $* *$ \\
\hline Penetration resistance $20-30 \mathrm{~cm}$ & $\mathrm{~N}$ & $155^{b}$ & $160^{\mathrm{b}}$ & $124^{\text {a }}$ & $* *$ \\
\hline Crumbs in $0-10 \mathrm{~cm}$ & g. $100 \mathrm{~g}^{-1}$ & 60.0 & 67.5 & 72.5 & n.s. \\
\hline Water infiltration & $\mathrm{mm} \mathrm{min} \mathrm{m}^{-1}$ & $1.5^{\mathrm{a}}$ & $5.4^{b}$ & - & $*$ \\
\hline Soil moisture & g. $100 \mathrm{~g}^{-1}$ & $52.3^{b}$ & $54.0^{b}$ & $51.1^{\mathrm{a}}$ & $* *$ \\
\hline
\end{tabular}

${ }^{\dagger}$ Significance of the location effect: ${ }^{*} P \leq 0.05 ;{ }^{* *} P \leq 0.01 ;{ }^{* * *} P \leq 0.001 ;$ n.s. $P>0.05$.

Table S4.2 Lists of potential explanatory parameters included in RDA, per data set, based on VIF (see Methods).

\begin{tabular}{|c|c|}
\hline Data set: & Included parameters \\
\hline Locations A, B, C & $\begin{array}{l}\mathrm{CEC}, \mathrm{Ca}: \mathrm{Mg} \text { ratio, } \mathrm{HWC}, \mathrm{N}_{\text {total, }} \mathrm{C}_{\text {total, }}, \mathrm{P}_{\text {total, }}, \mathrm{P}_{\mathrm{AL}}, \mathrm{pH} \text { KCl, } \mathrm{SOM} \text {, load bearing capacity, } \\
\text { penetration resistance in } 0-10 \mathrm{~cm} \text {, in } 10-20 \mathrm{~cm} \text { and in } 20-30 \mathrm{~cm} \text {, percentage of crumbs } \\
\text { in } 0-10 \mathrm{~cm}\end{array}$ \\
\hline Location A & $\begin{array}{l}\mathrm{CEC}, \mathrm{Ca}: \mathrm{Mg} \text { ratio, } \mathrm{HWC}, \mathrm{N}_{\text {total, }} \mathrm{C}_{\text {total, }}, \mathrm{P}_{\text {total, }}, \mathrm{P}_{\mathrm{AL}}, \mathrm{pH}_{\mathrm{KCl}} \text {, load bearing capacity, penetration } \\
\text { resistance in } 10-20 \mathrm{~cm} \text { and in } 20-30 \mathrm{~cm} \text {, percentage of crumbs in } 0-10 \mathrm{~cm} \text {, water } \\
\text { infiltration rate }\end{array}$ \\
\hline Location B & $\begin{array}{l}\mathrm{CEC}, \mathrm{Ca}: \mathrm{Mg} \text { ratio, } \mathrm{HWC}, \mathrm{N}_{\text {total, }} \mathrm{C}_{\mathrm{total}}, \mathrm{pH} \mathrm{KCl}_{\mathrm{KC}} \text { load bearing capacity, penetration resistance } \\
\text { in } 0-10 \mathrm{~cm} \text {, percentage of crumbs in } 0-10 \mathrm{~cm} \text {, water infiltration rate, saprotrophic } \\
\text { fungal PLFA, AMF spores NLFA, actinomycetes PLFA, decomposition rate }(k)\end{array}$ \\
\hline Location C & $\begin{array}{l}\mathrm{CEC}, \mathrm{Ca}: \mathrm{Mg} \text { ratio, } \mathrm{HWC}, \mathrm{P}_{\mathrm{AL}}, \mathrm{pH}_{\mathrm{KCl}}, \mathrm{SOM} \text {, load bearing capacity, penetration resistance } \\
\text { in } 0-10 \mathrm{~cm} \text {, percentage of crumbs in } 0-10 \mathrm{~cm}\end{array}$ \\
\hline
\end{tabular}


Table S4.3 Soil parameters with significant treatment $\times$ location interaction: Ca:Mg ratio, organic matter (SOM), hot water extractable carbon (HWC), $P_{\text {total }}$ and penetration resistance $(P R)$ in $10-20 \mathrm{~cm}$ and $20-30 \mathrm{~cm}$. $P$-value of the treatment $\times$ location interaction in brackets. Within a location, means with the same superscript are not significantly different.

\begin{tabular}{|c|c|c|c|c|c|c|c|}
\hline Parameter & Unit & Location & Control & $\mathrm{CaCO}_{3}$ & $\mathrm{CaSO}_{4}$ & $\mathrm{MgCO}_{3}$ & $\mathrm{MgSO}_{4}$ \\
\hline \multirow[t]{3}{*}{ Ca:Mg (<0.001) } & - & A & $6.9^{c}$ & $8.6^{d}$ & $9.0^{\mathrm{e}}$ & $5.5^{b}$ & $3.2^{\mathrm{a}}$ \\
\hline & & B & $4.0^{c}$ & $6.3^{e}$ & $5.5^{d}$ & $3.5^{b}$ & $2.4^{\mathrm{a}}$ \\
\hline & & C & $2.9^{\mathrm{c}}$ & $4.2^{d}$ & $4.5^{d}$ & $2.4^{\mathrm{b}}$ & $1.8^{\mathrm{a}}$ \\
\hline \multirow[t]{3}{*}{ SOM (0.009) } & g $100 \mathrm{~g}^{-1}$ & A & $35.2^{b c}$ & $32.6^{\mathrm{a}}$ & $36.3^{c}$ & $34.6^{b}$ & $34.8^{b}$ \\
\hline & & B & $44.3^{a}$ & $43.7^{\mathrm{a}}$ & $44.0^{a}$ & $43.3^{\mathrm{a}}$ & $44.4^{a}$ \\
\hline & & C & $34.2^{a b}$ & $34.1^{\mathrm{ab}}$ & $33.6^{a b}$ & $33.4^{\mathrm{a}}$ & $34.9^{b}$ \\
\hline \multirow[t]{3}{*}{ HWC (0.003) } & $\mu \mathrm{g} \mathrm{Cg}^{-1}$ & A & $6964^{b}$ & $6286^{a}$ & $7066^{b}$ & $7047^{b}$ & $7223^{b}$ \\
\hline & & B & $7510^{a b}$ & $7182^{a}$ & $7380^{a}$ & $7886^{b c}$ & $8188^{c}$ \\
\hline & & C & 6689 ab & $7274^{c}$ & $6382^{a}$ & $6987^{b c}$ & $6919 \mathrm{bc}$ \\
\hline \multirow[t]{3}{*}{$P_{\text {total }}(0.034)$} & $\mathrm{g} \mathrm{P}_{2} \mathrm{O}_{5} 100 \mathrm{~g}^{-1}$ & $A$ & $0.71^{\mathrm{c}}$ & $0.65^{\mathrm{a}}$ & $0.68^{b c}$ & $0.70^{b c}$ & $0.68^{\mathrm{ab}}$ \\
\hline & & B & $0.66^{a}$ & $0.66^{\mathrm{a}}$ & $0.67^{a}$ & $0.66^{\mathrm{a}}$ & $0.65^{a}$ \\
\hline & & C & $0.47^{a}$ & $0.47^{\mathrm{a}}$ & $0.47^{a}$ & $0.47^{\mathrm{a}}$ & $0.49^{a}$ \\
\hline PR $10-20 \mathrm{~cm}$ & $\mathrm{~N}$ & $\bar{A}$ & $154^{\text {a }}$ & $146^{\mathrm{a}}$ & $151^{\mathrm{a}}$ & $145^{a}$ & $146^{\mathrm{a}}$ \\
\hline \multirow[t]{2}{*}{$(0.011)$} & & B & $142^{a b}$ & $139^{a}$ & $152^{\mathrm{b}}$ & $143^{a b}$ & $132^{\mathrm{a}}$ \\
\hline & & C & $129^{a}$ & $132^{\mathrm{a}}$ & $161^{c}$ & $130^{\mathrm{a}}$ & $146^{b}$ \\
\hline PR 20-30 cm & $\mathrm{N}$ & A & $155^{b}$ & $128^{a}$ & $141^{a}$ & $129^{a}$ & $132^{\mathrm{a}}$ \\
\hline \multirow[t]{2}{*}{$(0.007)$} & & B & $160^{\text {a }}$ & $167^{a}$ & $180^{b}$ & $163^{a}$ & $172^{a}$ \\
\hline & & C & $124^{\mathrm{a}}$ & $129 \mathrm{ab}$ & $137^{b}$ & $123^{a}$ & $132 \mathrm{ab}$ \\
\hline
\end{tabular}

Table S4.4 Treatment effects on grass $\mathrm{N}$ content (g N.kg DM ${ }^{-1}$; calculated as total $\mathrm{N}$ yield per total DM yield) per year. Per row, means with the same superscript are not significantly different $(\alpha=0.05)$. Loc: location; Trt: treatment. $P$-values $\leq 0.05$ in bold.

\begin{tabular}{|c|c|c|c|c|c|c|c|}
\hline \multirow[b]{2}{*}{ Parameter } & \multicolumn{2}{|l|}{$P$-values } & \multicolumn{5}{|c|}{ Treatment means } \\
\hline & Loc $\times$ Trt. & Trt. & Control & $\mathrm{CaCO}_{3}$ & $\mathrm{CaSO}_{4}$ & $\mathrm{MgCO}_{3}$ & $\mathrm{MgSO}_{4}$ \\
\hline Grass N content 2015 & 0.130 & $<0.001$ & $22.8^{b}$ & $23.9^{c}$ & $22.2^{a}$ & $22.9^{b}$ & $22.5^{\mathrm{ab}}$ \\
\hline Grass N content 2016 & 0.185 & 0.004 & $21.8^{b}$ & $21.9^{b}$ & $21.0^{a}$ & $21.7^{b}$ & $20.8^{a}$ \\
\hline
\end{tabular}



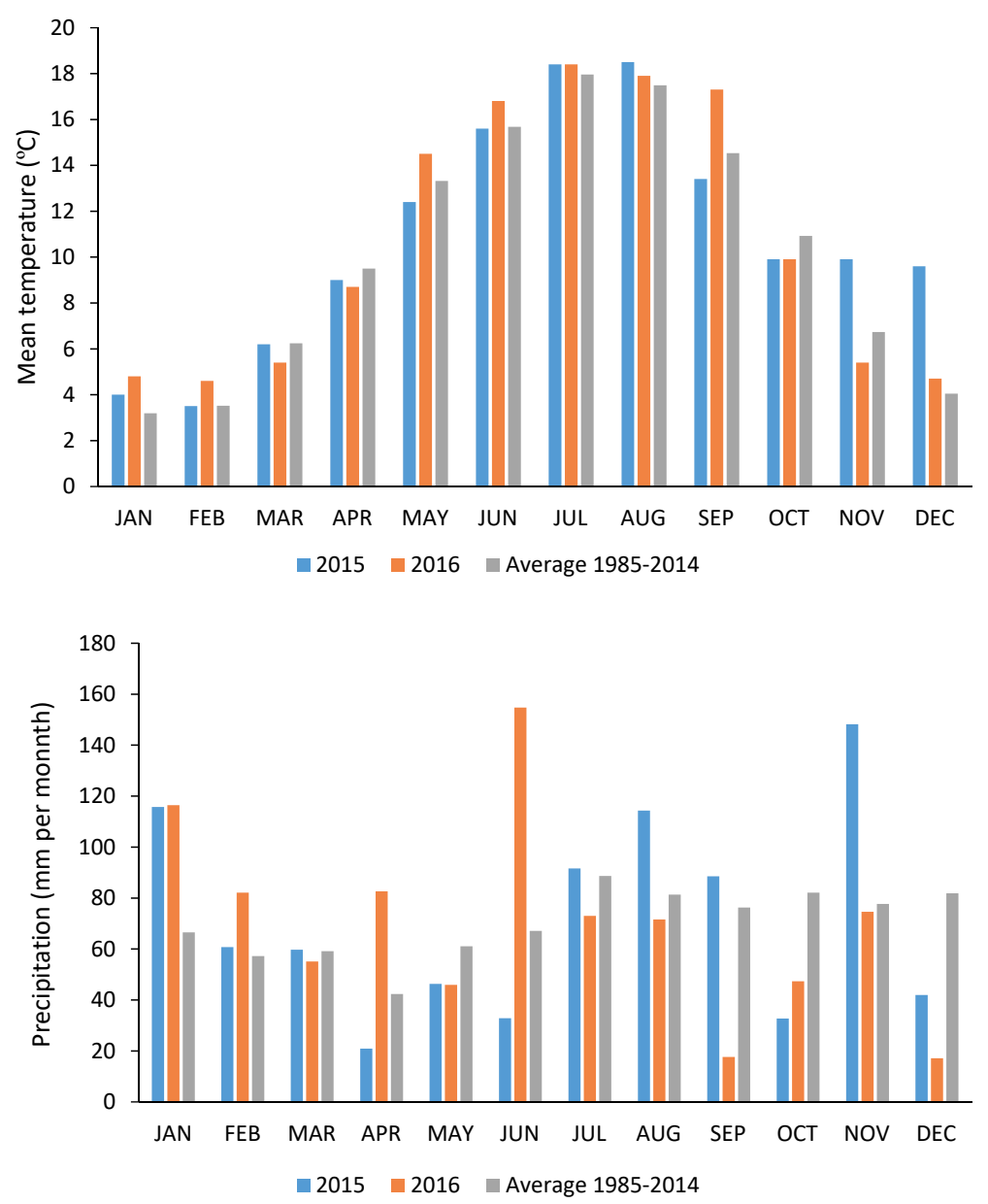

Figure S4.1: Monthly temperature and precipitation data from weather station De Bilt in 2015, 2016 and the long-term average (1985-2014). Source: www.knmi.nl. 

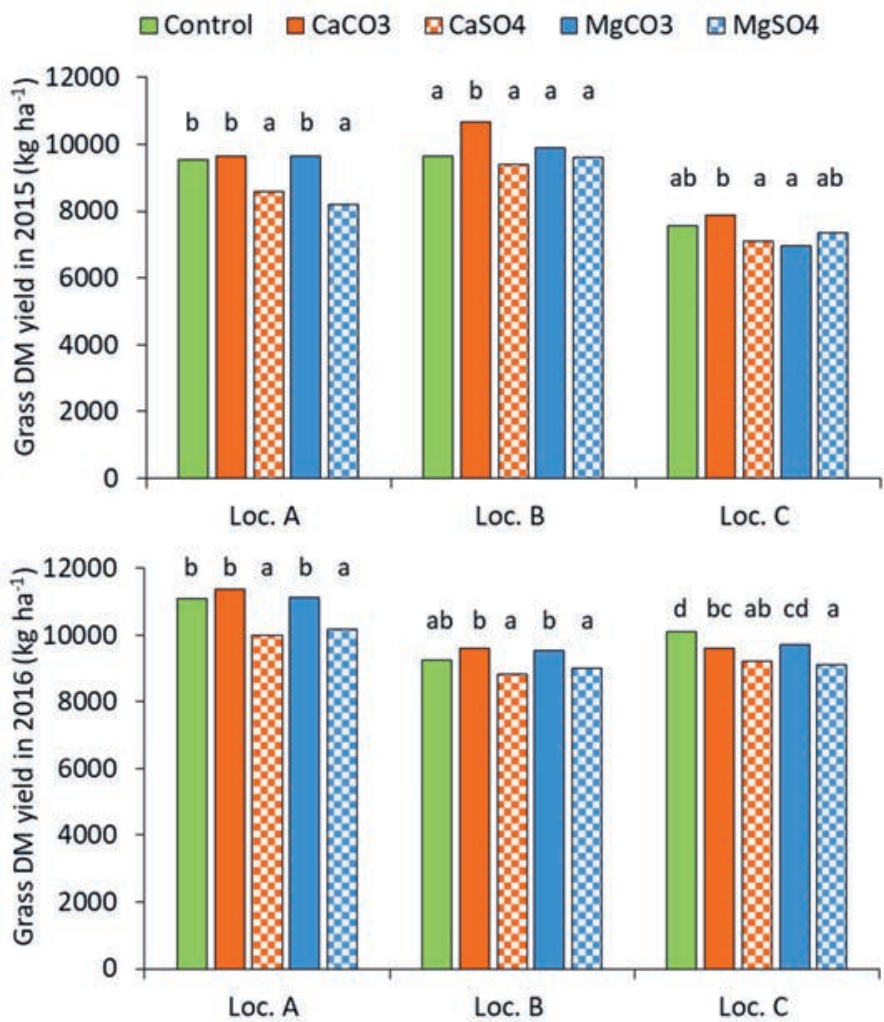

Figure S4.2 Grass DM yields $\left(\mathrm{kg} \mathrm{ha}^{-1} \mathrm{yr}^{-1}\right.$ ) for 2015 (above; significant location $\times$ treatment effect, $P=$ 0.014 ) and 2016 (above; significant location $\times$ treatment effect, $P=0.031$ ). In location $C, 2015$, grass DM yield does not include the $2^{\text {nd }}$ cut (see Methods). Within a year and location, bars with the same letter are not significantly different $(\alpha=5 \%)$. 


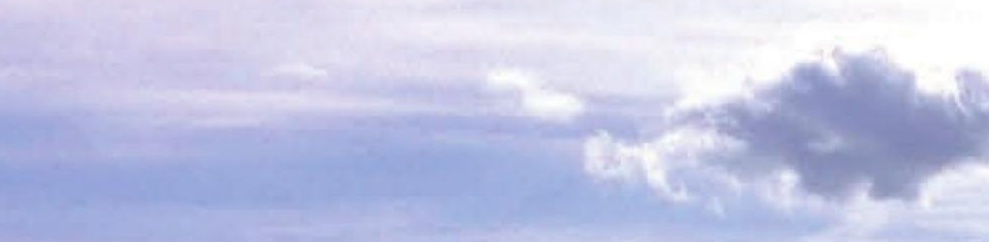

W
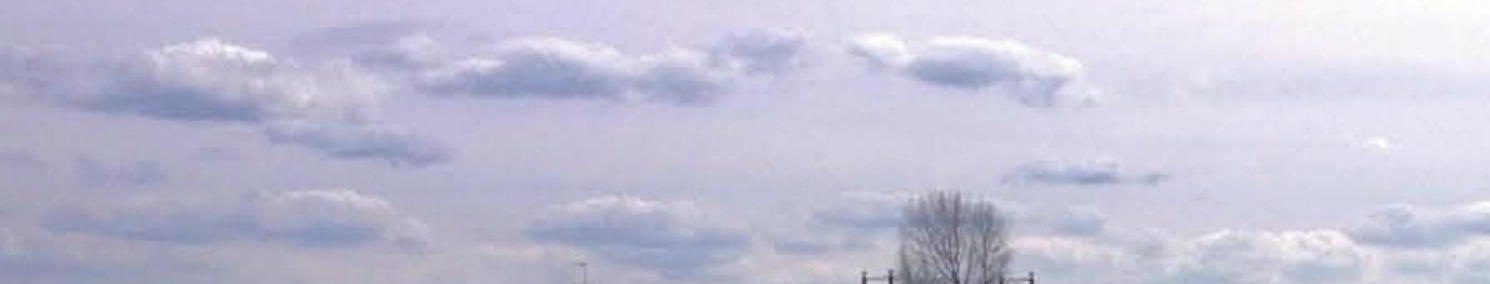

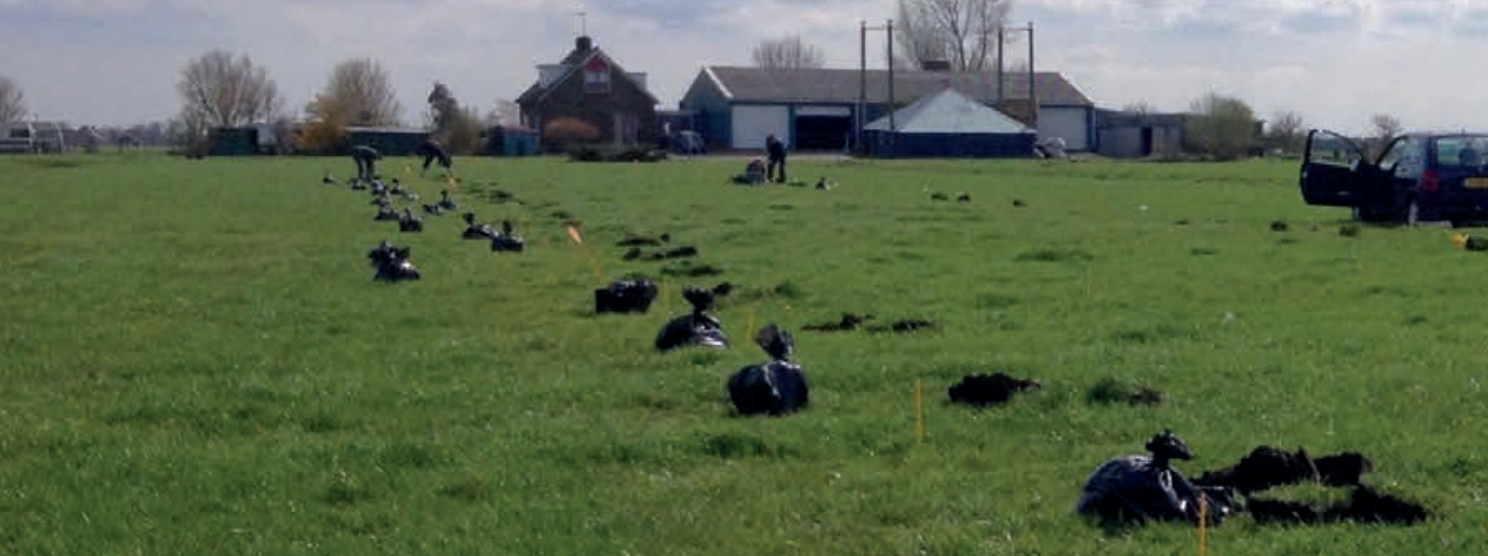

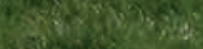

Lis inte

Hin $\rightarrow$ s.

eve.

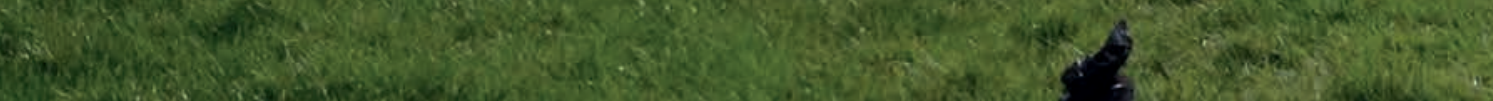

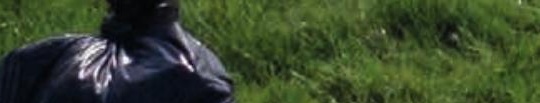

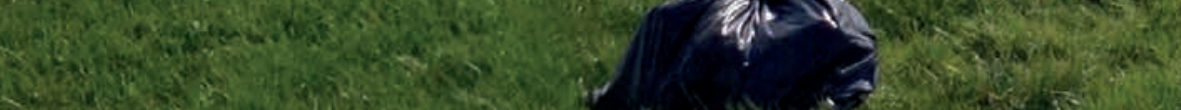

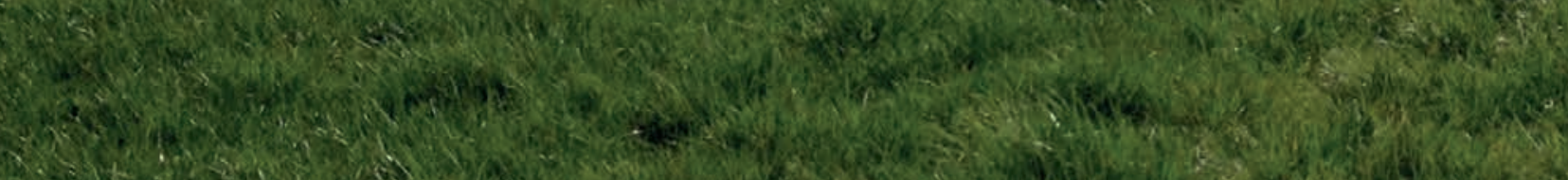

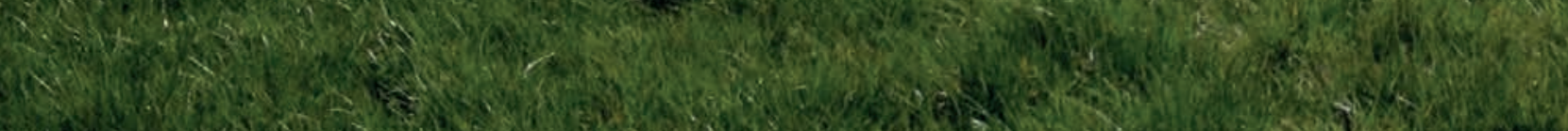
3.5.

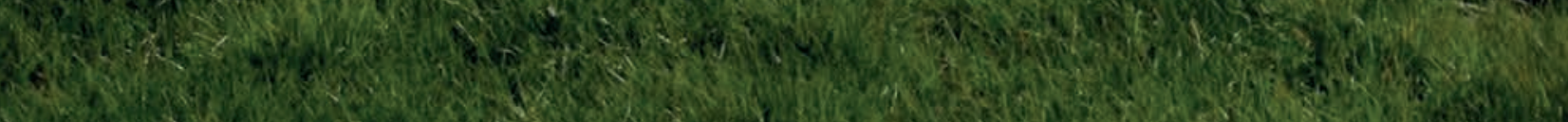

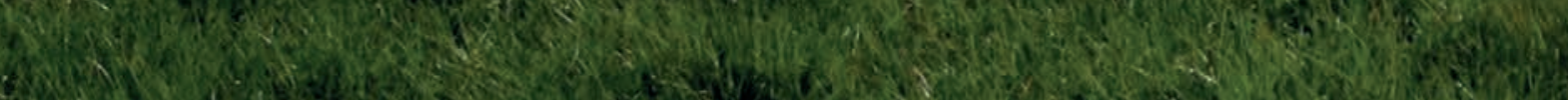
P.M. 1. 


\section{Chapter 5}

\section{Effects of organic and inorganic fertilizers on soil properties related to the regeneration of ecosystem services in peat grasslands}





\section{Abstract}

Under agri-environment schemes, semi-natural grasslands on drained peat are moderately fertilized with solid manure to support key biodiversity such as meadow birds that feed among others on (detritivorous) earthworms. This study provides a comprehensive assessment of the performance of fertilizers in relation to regeneration of soil ecosystem services of peat grasslands. In a three-year field experiment, effects of various organic fertilizers (cattle slurry, compost, farmyard manure and solid fraction of cattle slurry) and inorganic nitrogen (N) fertilizer (with and without added sawdust) were studied. Total $\mathrm{N}$ input was targeted at $120 \mathrm{~kg} \mathrm{ha}^{-1} \mathrm{yr}^{-1}$. Different carbon (C) quantities were applied due to different C:N ratios of source materials. Soil and aboveground measurements were carried out in relation to the ecosystem services support of biodiversity, water regulation, climate regulation and herbage production. We found an increase in (epigeic) earthworm abundance in spring with large quantities of organic matter input (solid fraction) and show that lignin-rich organic matter (sawdust) combined with mineral N promotes the reproduction of epigeic earthworms. Also soil microbial abundance and community structure was affected by fertilizers. Bacteria were increased with inorganic $N$ fertilizers, with little effect of the added C. Arbuscular mycorrhizal fungi were reduced by fertilizers except where large quantities of $\mathrm{C}$ were added (solid fraction) or where the added $\mathrm{C}$ was lignin-rich (sawdust + inorganic $\mathrm{N}$ fertilizer). Due to the relatively low fertilization rate and high soil organic matter (SOM) in peat, physical and chemical soil properties related to water infiltration and SOM decomposition were only marginally influenced by fertilizers. However, in the longer term or at higher fertilization rates, the measured changes in soil $\mathrm{pH}, \mathrm{P}$ availability and (micro)biology may affect SOM dynamics to a larger extent. Compared to the unfertilized control, grass dry matter yield was similarly increased by all fertilizers whereas grass $\mathrm{N}$ yield was increased by fertilizers only when the applied $\mathrm{N}$ was in mineral form. The low apparent $\mathrm{N}$ recovery of organic fertilizers $(-1$ to $+16 \%)$ was caused by a combination of the low application rate, low fertilizer mineral $\mathrm{N}$ content, and a high soil $\mathrm{N}$ supply. We conclude that the use of organic fertilizers with high and non-humified organic matter content such as solid fraction of cattle slurry can be part of a regeneration strategy of ecosystem services in peat grasslands.

\section{Keywords}

Manure; biodiversity; herbage production; soil quality; regenerative farming; earthworms; PLFA; soil organic matter; Histosols 


\subsection{Introduction}

The primary function of grasslands on drained peat soils is traditionally the production of herbage as an essential feed component for dairy cattle. This provisioning ecosystem service (MEA, 2005) is supported by an ample soil nutrient availability due to continuous mineralization of the oxic topsoil (Brouns et al., 2016; Sonneveld and Lantinga, 2011; Vellinga and André, 1999). A key issue in present farming practice is to optimize grass fertilization with minimal nutrient losses (Deru et al., 2019; Pijlman et al., 2020; Vellinga and André, 1999). In addition, society requires increasingly to integrate the delivery of supporting and regulating ecosystem services (MEA, 2005; Schröder et al., 2020; Van den Born et al., 2016). In drained peat grasslands, these requirements are related to the support of biodiversity (e.g. meadow birds; (Beintema, 1986)), the regulation of water quantity (Deru et al., 2018a; Van den Born et al., 2016) and the mitigation of climate change by minimizing the ongoing peat decomposition and associated nitrogen (N) mineralization, $\mathrm{N}$ and carbon (C) emission and land subsidence (Bobbink et al., 1998; Kasimir-Klemedtsson et al., 1997; Schothorst, 1977; Van den Born et al., 2016). To better integrate those ecosystem services, future farming should be regenerative, reduce external inputs (Erisman et al., 2016), and peat decomposition rate, and shift towards more use of organic and less use of inorganic fertilizers.

Agricultural grasslands with explicit biodiversity goals, for example under agrienvironment schemes (Verhulst et al., 2007), are often fertilized with straw-rich farm yard manure as this is considered to improve soil biological quality including earthworm abundance, and indirectly to sustain meadow bird populations (Onrust and Piersma, 2019; Oosterveld, 2006). The organic matter and minerals added to grasslands via organic fertilizers are a food source for detritivorous soil biota (Bünemann et al., 2006; De Goede et al., 2003; Onrust and Piersma, 2019) that affect soil physical properties important for the regulating ecosystem services of climate adaptation and water regulation (Brussaard et al., 1997; Deru et al., 2018a; Lavelle, 1997; Parfitt et al., 2010; Van Eekeren et al., 2009a). A broad range of organisms in higher trophic levels, among which meadow birds important for the supporting ecosystem service of biodiversity, are also benefited (Macdonald, 1983; Onrust and Piersma, 2017; Vickery et al., 2001). Moreover, organic matter input may partly compensate for soil organic matter (SOM) decomposition in peat soils. However, in current dairy farming with mostly cubicle barns with slatted floors, the availability of 
farmyard manure is restricted. At the same time, mechanical slurry separating techniques that produce a C-rich solid fraction are increasingly used (Gebrezgabher et al., 2015; Hjorth et al., 2010). This product may therefore be a valuable substitute for farmyard manure in grasslands under agri-environment schemes. For mineral soils, the value of inorganic and organic fertilizers in agricultural grassland for regeneration of soil quality and aboveground effects has been evaluated (Parfitt et al., 2010; Van Eekeren et al., 2009a), but for peat grasslands such information is lacking. The greatly differing soil properties and specific ecosystem services of drained peat grassland areas justify a separate assessment.

The objective of this paper is to assess the effects of inorganic and organic fertilizers on the regeneration of soil properties and aboveground parameters related to the delivery of the main ecosystem services in peat grassland: support of biodiversity, water regulation, climate regulation and herbage production (Deru et al., 2018a). In a field experiment, four organic fertilizers (cattle slurry manure, compost, cattle farmyard manure and the solid fraction of cattle slurry manure) and two inorganic fertilizers (inorganic $\mathrm{N}$ fertilizer only and a combination of inorganic $\mathrm{N}$ fertilizer and sawdust) were applied to grassland during three consecutive growing seasons. Application rate was based on $120 \mathrm{~kg}$ total $\mathrm{N} \mathrm{ha}^{-1} \mathrm{yr}^{-1}$ which is low for conventional dairy production grasslands but usual in grasslands under agri-environment schemes (Kleijn et al., 2001). Organic matter input was different per fertilizer due to the differences in $\mathrm{C}: \mathrm{N}$ ratio; the quantity of applied sawdust was based on the organic matter input in the compost treatment. In relation to the ecosystem services of interest, we hypothesized that: (1) higher amounts of applied organic matter result in higher abundance of earthworms, especially the detritivorous species, and microbial biomass; (2) organic fertilizers with high organic matter input and positive effects on soil biota increase soil porosity, water infiltration and rooting density and positively influence SOM; and (3) organic fertilizers with high mineral $\mathrm{N}$ contents and low $\mathrm{C}: \mathrm{N}$ ratio positively influence herbage dry matter and $\mathrm{N}$ yield due to a high availability of $\mathrm{N}$. 


\subsection{Materials and methods}

\subsubsection{Experimental setup}

A field experiment was conducted from 2013 till 2015 in the west of the Netherlands on a permanent grassland on peat soil (Terric Histosol; FAO 2014) at the experimental dairy

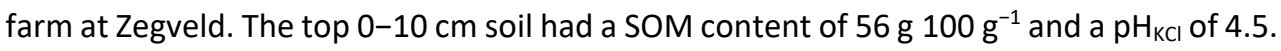
A randomized block experiment was laid out in March 2013 with six fertilizer treatments and a control treatment (no fertilizer; named "Contr" in this paper) in six blocks, resulting in 42 experimental plots. The six fertilizer types were: inorganic $\mathrm{N}$ fertilizer ("IF"; calcium ammonium nitrate, $27 \% \mathrm{~N}$ ), a combination of inorganic $\mathrm{N}$ fertilizer and sawdust ("IF+SD"), cattle slurry manure ("Slurry"), compost of kitchen and garden waste from a municipal composting plant ("Comp"), cattle farmyard manure ("FYM") and solid fraction of cattle slurry manure ("SFrac", obtained by pressurized filtration (Hjorth et al., 2010)). Plot size was $4 \times 10 \mathrm{~m}$, except for the Slurry plots that were $5.2 \times 10 \mathrm{~m}$ due to the width of the application device. Sampling and measurements occurred at minimum $0.5 \mathrm{~m}$ from the plot borders. Slurry was applied by slit injection (Huijsmans et al., 2001) and all other fertilizers were applied by hand. Fertilizer application rates were targeted at $120 \mathrm{~kg}$ total $\mathrm{N} \mathrm{ha}^{-1} \mathrm{yr}^{-1}$ (divided in two applications per year: one in February/March and one in May). However, due to fluctuating fertilizer $\mathrm{N}$ contents (especially FYM and Comp) and delayed fertilizer analyses, realized $\mathrm{N}$ application rates were not exactly $120 \mathrm{~kg} \mathrm{ha}^{-1} \mathrm{yr}^{-1}\left(\mathrm{~N}_{\min }+\mathrm{N}_{\text {org }}\right)$. Fertilizer application quantities and organic matter and nutrient inputs are presented in Table 5.1. The application rate of sawdust was adjusted to the amount of $C_{\text {total }}$ applied in the Comp treatment. All plots, including control plots, were additionally fertilized with 200 $\mathrm{kg} \mathrm{K}_{2} \mathrm{O} \mathrm{ha}^{-1} \mathrm{yr}^{-1}$, divided in two applications per year (March and May).

Before the experiment, the grassland had been managed conventionally with mainly cutting, winter grazing with sheep and a normal fertilization regime with both slurry manure and inorganic fertilizer (Commissie Bemesting Grasland en Voedergewassen, 2019). During the experiment, no fertilization was carried out in addition to the treatment amounts, but the normal grassland management was continued in the first two years. During the monitoring year of 2015 , the plots were only cut for herbage measurements (see below) and not grazed. 


\subsubsection{Measurements}

Soil and aboveground measurements were carried out from April to October 2015, and were selected to provide an overview of fertilizer effects of potential importance for the ecosystem services support of biodiversity, water regulation, climate regulation and herbage production. An overview of all measurements with the sampling dates is presented in Table 5.2. Most soil parameters were measured in October. As earthworms are an important food source for meadow birds during the pre-breeding period in spring (Galbraith, 1989), earthworm sampling was carried out in April. Soil moisture and penetration resistance were measured both in April and October.

Table 5.1 Application quantities of fertilizers (fresh and dry matter (DM) rates) and ash, organic matter (OM), $C$ and mineral inputs, and fertilizer $C: N$ ratio. Total $N$ input is the sum of mineral $N\left(N_{\min }\right)$ and organic $N\left(N_{\text {org }}\right)$. Average values per hectare and per year over the years 2013-2015.

\begin{tabular}{|c|c|c|c|c|c|c|c|c|c|}
\hline \multirow[b]{2}{*}{ Treatment $^{\dagger}$} & \multicolumn{2}{|c|}{ Fertilizer } & $\mathrm{Ash}^{\ddagger}$ & OM & $C$ & $\mathrm{~N}_{\min }$ & $N_{\text {org }}$ & $\mathrm{P}_{2} \mathrm{O}_{5}$ & \multirow[t]{2}{*}{$\mathrm{C}: \mathrm{N}$} \\
\hline & $\begin{array}{l}\mathrm{Mg} \mathrm{ha}^{-1} \\
\text { (fresh) }\end{array}$ & $\begin{array}{c}\mathrm{Mg} \mathrm{ha}^{-1} \\
\text { (DM) }\end{array}$ & \multicolumn{6}{|c|}{$\mathrm{kg} \mathrm{ha}^{-1}$} & \\
\hline Contr & - & - & - & - & - & - & - & - & - \\
\hline IF & 0.45 & 0.45 & 0 & 0 & 0 & 120 & 0 & 0 & 0 \\
\hline $\mathrm{IF}+\mathrm{SD}$ & 3.77 & $3.17^{\mathbb{P}}$ & 27 & 2679 & 1443 & 120 & 3 & 0 & 11.7 \\
\hline Slurry & 43.2 & 2.39 & 615 & 1778 & 796 & 58 & 61 & 43 & 6.7 \\
\hline Comp & 10.4 & 7.38 & 4106 & 3272 & 1472 & 4 & 109 & 50 & 12.9 \\
\hline FYM & 22.9 & 5.10 & 802 & 4284 & 1922 & 15 & 118 & 73 & 14.3 \\
\hline SFrac & 24.5 & 6.89 & 644 & 6240 & 2802 & 26 & 97 & 69 & 22.8 \\
\hline
\end{tabular}

${ }^{\dagger}$ Treatment codes: Contr: control, IF: inorganic N fertilizer, IF+SD: inorganic N fertilizer and sawdust, Slurry: cattle slurry manure, Comp: compost, FYM: farmyard manure, SFrac: solid fraction of cattle slurry manure. ${ }^{\ddagger}$ mineral fraction.

$\mathbb{R} 2.72 \mathrm{Mg}$ sawdust $+0.45 \mathrm{Mg} \mathrm{N}$ fertilizer.

Table 5.2 Overview of aboveground and belowground measurements and sampling dates.

\begin{tabular}{|c|c|c|}
\hline Set & Measurements & Sampling date in 2015 \\
\hline Soil biological & $\begin{array}{l}\text { Earthworms; leatherjackets; wireworms } \\
\text { microbial phospholipid fatty acids (PLFA) }\end{array}$ & $\begin{array}{l}\text { April } 13^{\text {th }} \\
\text { October } 13^{\text {th }}\end{array}$ \\
\hline Soil chemical & $\begin{array}{l}\mathrm{pH}_{\mathrm{KCl}} ; \mathrm{N}_{\text {total }} ; \mathrm{P}_{\text {total }} ; \mathrm{P}_{\mathrm{AL}} ; \mathrm{C}_{\text {total }} \text {; soil organic matter } \\
\text { (SOM); hot water extractable carbon (HWC) }\end{array}$ & October $13^{\text {th }}$ \\
\hline Soil physical & $\begin{array}{l}\text { Penentration resistance; soil moisture; } \\
\text { soil structure; root density; water infiltration }\end{array}$ & $\begin{array}{l}\text { April } 13^{\text {th }} \text { and October } 13^{\text {th }} \\
\text { October } 13^{\text {th }}\end{array}$ \\
\hline Grass yield & Dry matter yield, $\mathrm{N}$ content, $\mathrm{N}$ yield & May $15^{\text {th }}$, June $29^{\text {th }}$, Aug. $19^{\text {th }}$, Sept. $30^{\text {th }}$ \\
\hline Botanical & Plant soil cover and species & June $19^{\text {th }}$ \\
\hline
\end{tabular}




\subsubsection{Soil biological parameters}

Earthworms and insect larvae were sampled in April in two soil cubes $(20 \times 20 \times 20 \mathrm{~cm})$ per plot. The deeper living anecic earthworms were absent in this peat region (Deru et al., 2018a). Earthworms were hand-sorted, counted, weighed and fixed in alcohol prior to identification. Numbers and biomass were expressed per $\mathrm{m}^{2}$. Adults and juveniles were identified to species (Sims and Gerard, 1985; Stöp-Bowitz, 1969) and classified into functional groups (epigeic, endogeic and anecic species) (Bouché, 1977). Larvae of crane flies (Tipulidae; leatherjackets) or click beetles (Elateridae; wireworms) were counted and numbers were expressed per $\mathrm{m}^{2}$.

Phospholipid fatty acids (PLFA) were analyzed in a field-moist soil sub-sample of the soil sampled in October for the soil chemical analyses (see 5.2.2.2). PLFA were measured as a proxy of microbial biomass and to examine microbial community structure. PLFA were extracted from $4 \mathrm{~g}$ of fresh soil using the procedure described by Palojärvi (2006), and analyzed by gas chromatography (Hewlett-Packard, Palto Alto, CA, USA). PLFA are the primary lipids composing the membranes of living cells. Phospholipid fatty acids i15:0,

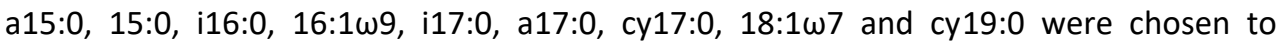
represent bacteria and PLFA 18:2 $2 \omega 6$ was used as a marker of saprotrophic fungi (Hedlund, 2002). The neutral lipid fatty acid (NLFA) 16:1w5, which occurs in storage lipids (such as spores) of arbuscular mycorrhizal fungi (AMF), was used as marker of AMF (Vestberg et al., 2012). The sum of PLFA i15:0, a15:0, i16:0, i17:0 and a17:0 was used as a measure of Gram-positive bacteria, and cy17:0 and cy19:0 as representing Gram-negative bacteria. PLFA 10Me16:0, 10Me17:0 and 10Me18:0 were used for measures of actinomycetes.

\subsubsection{Soil chemical parameters}

A soil sample from each experimental plot consisting of c. 50 randomly taken soil cores was collected in October from the 0-10 cm layer (auger diameter $2.3 \mathrm{~cm}$; Eijkelkamp grass plot sampler, Giesbeek, the Netherlands), sieved through a $1 \mathrm{~cm}$ mesh to remove plant remains and debris, and homogenized. Sub-samples were taken for determination of hot water extractable carbon (HWC) according to the method of Ghani et al. (2003), PLFA (see 5.2.2.1.) and chemical analysis. The sub-sample for chemical analysis was dried at $40^{\circ} \mathrm{C}$ prior to analysis of soil acidity $\left(\mathrm{pH}_{\mathrm{KCl}}\right)$, soil organic matter $(\mathrm{SOM})$, total carbon $\left(\mathrm{C}_{\text {total }}\right)$, total nitrogen $\left(\mathrm{N}_{\text {total }}\right)$, total phosphorus $\left(\mathrm{P}_{\text {total }}\right)$ and ammonium-lactate extractable $\mathrm{P}\left(\mathrm{P}_{\mathrm{AL}}\right)$ by 
Eurofins Agro (Wageningen, the Netherlands). Soil $\mathrm{pH}_{\mathrm{KCl}}$ was measured in $1 \mathrm{M} \mathrm{KCl}$ (NENISO 10390 2005). SOM was determined by loss-on-ignition at $550^{\circ} \mathrm{C}$ during $3 \mathrm{~h}$ after drying at $105^{\circ} \mathrm{C}$ during $6 \mathrm{~h}$ (NEN 5754 2005). $\mathrm{C}_{\text {total }}$ was measured by incineration of dry material at $1150^{\circ} \mathrm{C}$, after which the $\mathrm{CO}_{2}$ produced was determined by an infrared detector (LECO Corporation, St. Joseph, Mich., USA). For determination of $\mathrm{N}_{\text {total, }}$ evolved gasses after incineration were reduced to $\mathrm{N}_{2}$ and measured with a thermal-conductivity detector (LECO

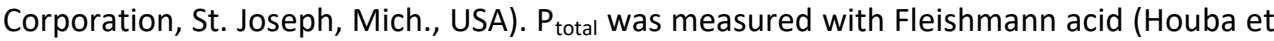
al., 1997) and $\mathrm{P}_{\mathrm{AL}}$, commonly used in the Netherlands to assess the $\mathrm{P}$ supply capacity of grassland soils (Reijneveld et al., 2014), was determined according to Egnér et al. (1960) (NEN 5793).

\subsubsection{Soil physical parameters}

Soil moisture was determined in April and October in a homogenized 0-10 cm soil sample (see 5.2.2.2). Soil was dried at $105^{\circ} \mathrm{C}$ for $24 \mathrm{hrs}$ and moisture content was expressed as percentage of fresh soil weight.

Penetration resistance was measured in April and October in each plot using an electronic penetrologger (Eijkelkamp, Giesbeek, the Netherlands) with a cone with $2.0 \mathrm{~cm}^{2}$ penetration surface and a $60^{\circ}$ apex angle. Cone resistance was recorded per $\mathrm{cm}$ of soil depth and expressed as an average of 7 penetrations per layer $(0-10,10-20$, and $20-30$ $\mathrm{cm})$.

Soil structure and rooting were determined in October in two soil cubicles $(20 \times 20$ $\mathrm{cm}$ ) per experimental plot between the soil depth of $0-10 \mathrm{~cm}$ and of $10-25 \mathrm{~cm}$. In each cubicle the percentage of crumbs, sub-angular blocky elements and angular blocky elements was visually estimated by one experienced person as described by Peerlkamp (1959) and Shepherd (2000), and root density was assessed by scoring visible roots (score 1-10; 1 for no roots and 10 for above average).

Water infiltration rate was measured in October at three randomly chosen spots per experimental plot as described by Van Eekeren et al. (2010). Measurements were carried out in 5 of the 6 blocks ( 35 plots). A PVC pipe of $15 \mathrm{~cm}$ high and $15 \mathrm{~cm}$ in diameter was pushed into the soil to a depth of $10 \mathrm{~cm}$. To determine infiltration rate, $500 \mathrm{ml}$ water was poured into each pipe and the infiltration time was recorded. When the infiltration time exceeded $15 \mathrm{~min}$, the remaining water volume was estimated and the infiltration time for 
$500 \mathrm{ml}$ was calculated by linear extrapolation. From these data, the infiltration rate $(\mathrm{mm}$ $\min ^{-1}$ ) was calculated.

\subsubsection{Grass yield and botanical composition}

Grass dry matter (DM) and N yield were measured in four harvests during 2015 with a Haldrup plot harvester (J. Haldrup a/s, Løgstør, Denmark). Harvest dates were May 15, June 29, August 19 and September 30. For each harvest, fresh biomass, DM content after drying at $70^{\circ} \mathrm{C}$ for $24 \mathrm{hrs}$ and total $\mathrm{N}$ content (Kjeldahl) were determined. From these data, herbage DM yield ( $\left.\mathrm{Mg} \mathrm{DM} \mathrm{ha}{ }^{-1}\right)$ and herbage $\mathrm{N}$ yield $\left(\mathrm{kg} \mathrm{N} \mathrm{ha}^{-1}\right)$ were calculated per harvest and summed per year. Apparent $\mathrm{N}$ recovery $\left(\mathrm{kg} \mathrm{N} . \mathrm{kg} \mathrm{N}^{-1}\right.$ ) was calculated according to Vellinga and Andre (1999) as ( $\mathrm{N}$ yield ${ }_{(\text {fertilized) }}-\mathrm{N}$ yield (non-fertilized) $_{\text {) }} /(\mathrm{N}$ fertilization rate).

Measurement of botanical composition took place on the $19^{\text {th }}$ of June following the method of Sikkema (1997) and consisted of visually estimating the relative soil cover of the sward and the proportion of each species therein (relative abundance).

\subsubsection{Statistical analyses}

The Shapiro-Wilk test of normality (Royston, 1982) was used in R (version 3.4.4) to test for normal distribution of the residuals of treatments and blocks. Parameters that did not meet the assumption of normality of residuals were log-transformed prior to further statistical analysis. The significance of the treatment effect was calculated for each parameter by analysis of variance (ANOVA; Genstat $19^{\text {th }}$ edition, VSN international) using one-way ANOVA (randomized block design). In cases of significant effects $(P \leq 0.05)$, least significant differences between means were determined (I.s.d.; $\alpha=5 \%$ ). Finally, for the parameters showing significant treatment effects, principal component analysis (PCA) was performed in R (packages vegan 2.5-4 and packfor 0.0-8) to visualize the variation of these parameters across treatments and provide an overview of their correlations as projected on the first two principal components (PC1 and PC2). 


\subsection{Results}

\subsubsection{Soil properties}

\subsubsection{Earthworms and insect larvae}

The total number of earthworms was lowest in IF (271 earthworms $\mathrm{m}^{-2}$ ) and highest in SFrac (480 earthworms $\mathrm{m}^{-2}$ ), and the number in SFrac was higher than all treatments but Contr and IF+SD (Fig. 5.1A; Table S5.1 in Supplementary material). The number of epigeic earthworms (Fig. 5.1B; 96-230 earthworms $\mathrm{m}^{-2}$ ) and total earthworm biomass (Fig. 5.1C;
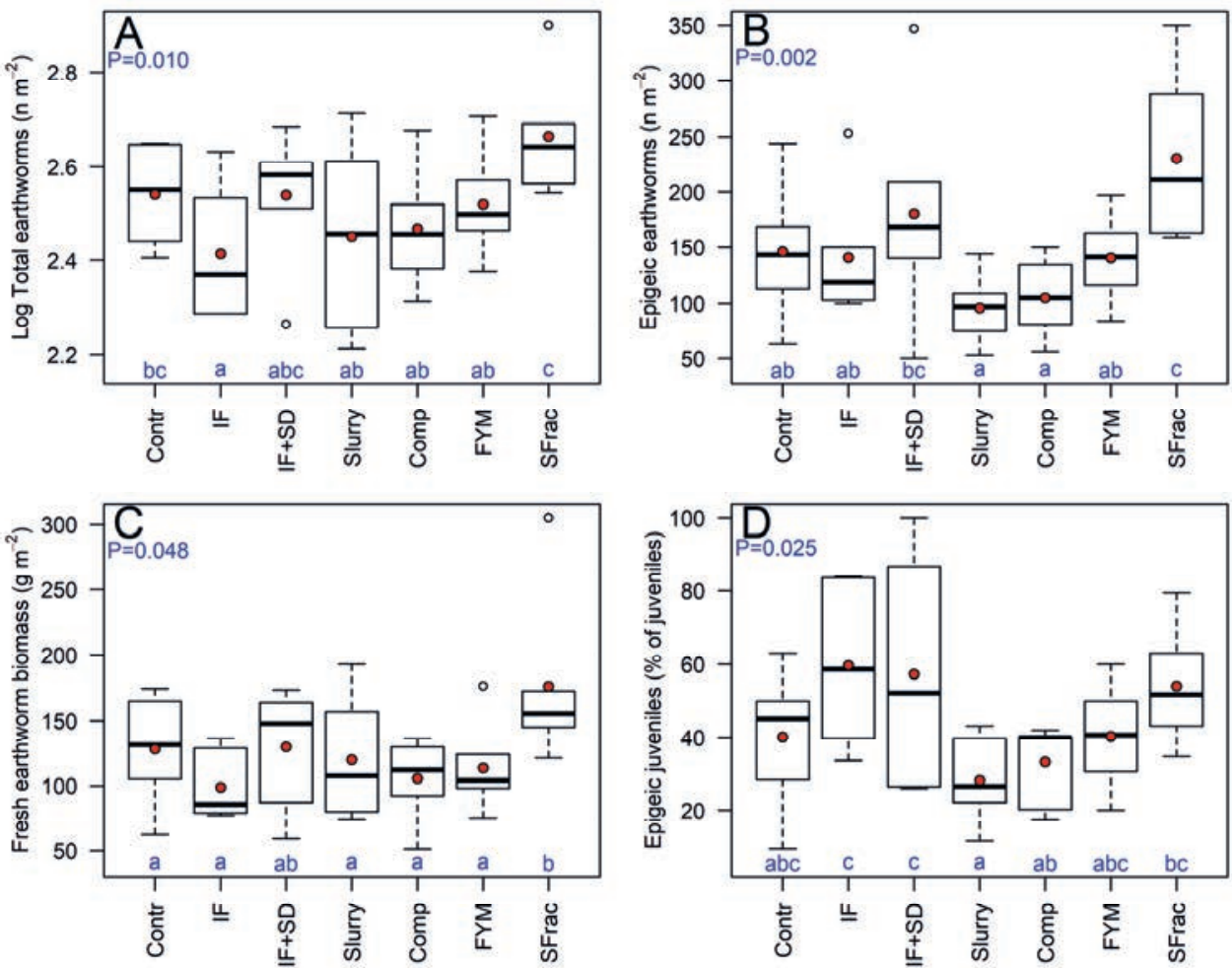

Figure 5.1 Effects of fertilizers on earthworm numbers (A: total; B: epigeic), fresh biomass (C) and proportion of juvenile epigec earthworms (D). Panel $A$ is based on log transformed data. Untransformed data are available in Table S5.1. Treatment codes: Contr: control, IF: inorganic N fertilizer, IF+SD: inorganic $N$ fertilizer with sawdust, Slurry: cattle slurry manure, Comp: compost, FYM: farmyard manure, SFrac: solid fraction of cattle slurry manure. Red dot: mean; thick horizontal line: median; vertical size of the box: interquartile range; whisker: variability outside the quartile; open dot: outliers (if any). Overall significance of treatment effect is indicated in each panel. At $P \leq 0.05$, the means of treatments with a similar letter do not significantly differ. 
99-175 g fresh weight $\mathrm{m}^{-2}$ ) were also highest in SFrac; only IF+SD was not significantly lower than SFrac. Of all juveniles, the percentage of epigeic ones was lowest in Slurry and Comp and highest in IF, IF+SD and SFrac (Fig. 5.1D). Endogeic earthworms (130-250 worms $\mathrm{m}^{-2}$ ) were not significantly influenced by treatments.

The number of earthworms correlated positively with soil chemical parameters, especially $P_{\text {total }}$ (Table 5.3). Epigeic and juvenile earthworms were most responsive to these soil parameters.

The sum of leatherjackets and wireworms numbers ranged between 84 and $234 \mathrm{~m}^{-2}$. The abundance of wireworms, but not of leatherjackets, was significantly influenced by fertilizer type. Wireworm density was lowest in Contr and Comp, and highest in Slurry, FYM and SFrac (Table S5.1).

Table 5.3 Pearson correlations ( $r ; n=42$ ) of earthworm parameters (subgroups in absolute numbers) with soil chemical parameters and fertilizer input of organic matter and mineral $\mathrm{N}$ (average of 2013-2015) across all treatments. Only significant correlations are presented: standard font: $P \leq 0.05$; bold: $P \leq 0.001$.

\begin{tabular}{lcccccc}
\hline & \multicolumn{5}{c}{ Earthworm parameter } \\
\cline { 2 - 6 } & $\begin{array}{c}\text { Total } \\
\text { number }\end{array}$ & Epigeic & Endogeic & Adults & Juveniles & $\begin{array}{c}\text { \% of juv. } \\
\text { epigeic }\end{array}$ \\
\hline $\begin{array}{l}\text { Soil parameter } \\
\mathrm{N}_{\text {total }}\end{array}$ & & 0.44 & & & & 0.35 \\
$\mathrm{P}_{\text {total }}$ & 0.50 & 0.36 & 0.39 & 0.45 & 0.41 & \\
$\mathrm{P}_{\mathrm{AL}}$ & 0.37 & & 0.35 & & 0.37 & \\
$\quad$ SOM & & 0.32 & & & & 0.40 \\
$\begin{array}{l}\text { Fertilizer input } \\
\text { Organic matter }\end{array}$ & 0.35 & 0.32 & & & 0.40 & \\
$\quad$ Mineral N & & & & & & 0.35 \\
\hline
\end{tabular}

\subsubsection{Microbial phospholipid fatty acids (PLFA)}

Inorganic N fertilizer (IF and IF+SD) resulted in the highest PLFA concentrations, a significant increase compared to the treatments with organic fertilizers. Slurry and Comp reduced PLFA concentrations compared to Contr (Fig. 5.2A). Broadly the same patterns were observed for bacterial, fungal, Gram-positive and Gram-negative PLFA (Table S5.2). Arbuscular mycorrhizal fungi (AMF; as indicated by NLFA) was reduced in all treatments compared to Contr, especially in FYM and Comp (Fig. 5.2B). SFrac and IF+SD showed the smallest reductions. The fungal:bacterial PLFA ratio was lowest in IF and highest in Comp 
(Fig. 5.2C). The Gram-positive to Gram-negative ratio was reduced in IF+SD compared to Contr, and was highest in SFrac (Fig. 5.2D).

PLFA parameters were weakly correlated with soil chemical parameters and more strongly with fertilizer $\mathrm{N}$ and $\mathrm{P}$ input (Table 5.4). Total microbial PLFA, and also bacterial, fungal, gram-positive and gram-negative PLFA, correlated positively with $\mathrm{N}_{\text {min }}$ input but negatively with $\mathrm{N}_{\text {org }}$ and $\mathrm{P}$ input. AMF NLFA was negatively correlated with $\mathrm{N}$ and $\mathrm{P}$ input.

\subsubsection{Chemical and physical soil properties}

SOM, $\mathrm{pH}_{\mathrm{KCl}}$ and $\mathrm{P}_{\mathrm{AL}}$ were significantly influenced by treatments (Fig. 5.3), but not $\mathrm{C}_{\text {total, }}$ HWC, $\mathrm{N}_{\text {total, }} \mathrm{C}: \mathrm{N}$ ratio or $\mathrm{P}_{\text {total }}$ (Table S5.3). SOM was lowest in Slurry and Comp; in Comp (55.0\%) this was significantly lower than in Contr (56.0\%). The lowest $\mathrm{pH}_{\mathrm{KCl}}$ was found in IF
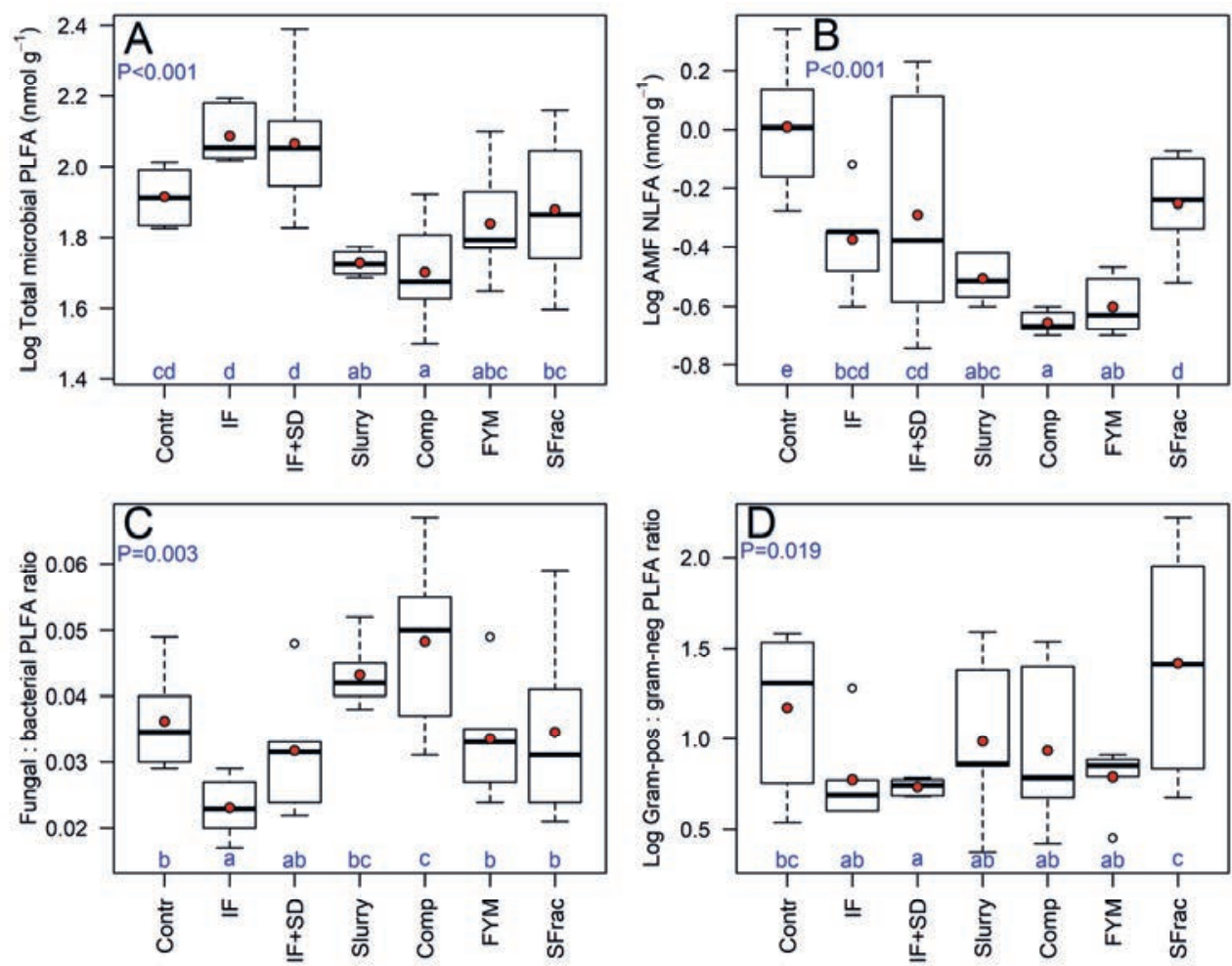

Figure 5.2 Effects of fertilizers on soil microbial community structure as indicated by PLFA and NLFA: total microbial PLFA (A), arbuscular mycorrhizal fungi (AMF) NLFA (B), fungal:bacterial PLFA ratio (C) and gram positive to gram negative PLFA ratio (D). Panels $A, B$ and $D$ are based on log transformed data. Untransformed data are available in Table S5.2. Treatment codes, figure explanation: see Fig. 5.1 . 
Table 5.4 Pearson correlations $(r ; n=42)$ of PLFA parameters with soil chemical parameters and fertilizer input of organic matter and mineral $N$ (average of 2013-2015) across all treatments. Only significant correlations are presented: standard font: $P \leq 0.05$; bold: $P \leq 0.001$.

\begin{tabular}{|c|c|c|c|c|}
\hline & \multicolumn{4}{|c|}{ PLFA parameter $^{\dagger}$} \\
\hline & Total microbial & AMF NLFA & Fung.:Bact. ratio & G.-pos:G.-neg ratio \\
\hline \multicolumn{5}{|c|}{ Soil parameter } \\
\hline $\mathrm{pH}_{\mathrm{KCL}}$ & -0.37 & & 0.37 & \\
\hline$P_{\text {total }}$ & & & & -0.37 \\
\hline $\mathrm{P}_{\mathrm{AL}}$ & & & & -0.42 \\
\hline \multicolumn{5}{|c|}{ Fertilizer input } \\
\hline Total N & & -0.56 & & \\
\hline Mineral N & 0.53 & & -0.41 & \\
\hline Organic $\mathrm{N}$ & -0.54 & -0.52 & 0.35 & \\
\hline $\mathrm{P}$ & -0.50 & -0.44 & & \\
\hline
\end{tabular}

${ }^{\dagger}$ Correlation coefficients and significances for bacterial, fungal, gram-positive and gram-negative PLFA with soil and fertilizer parameters were similar to those of total microbial PLFA.
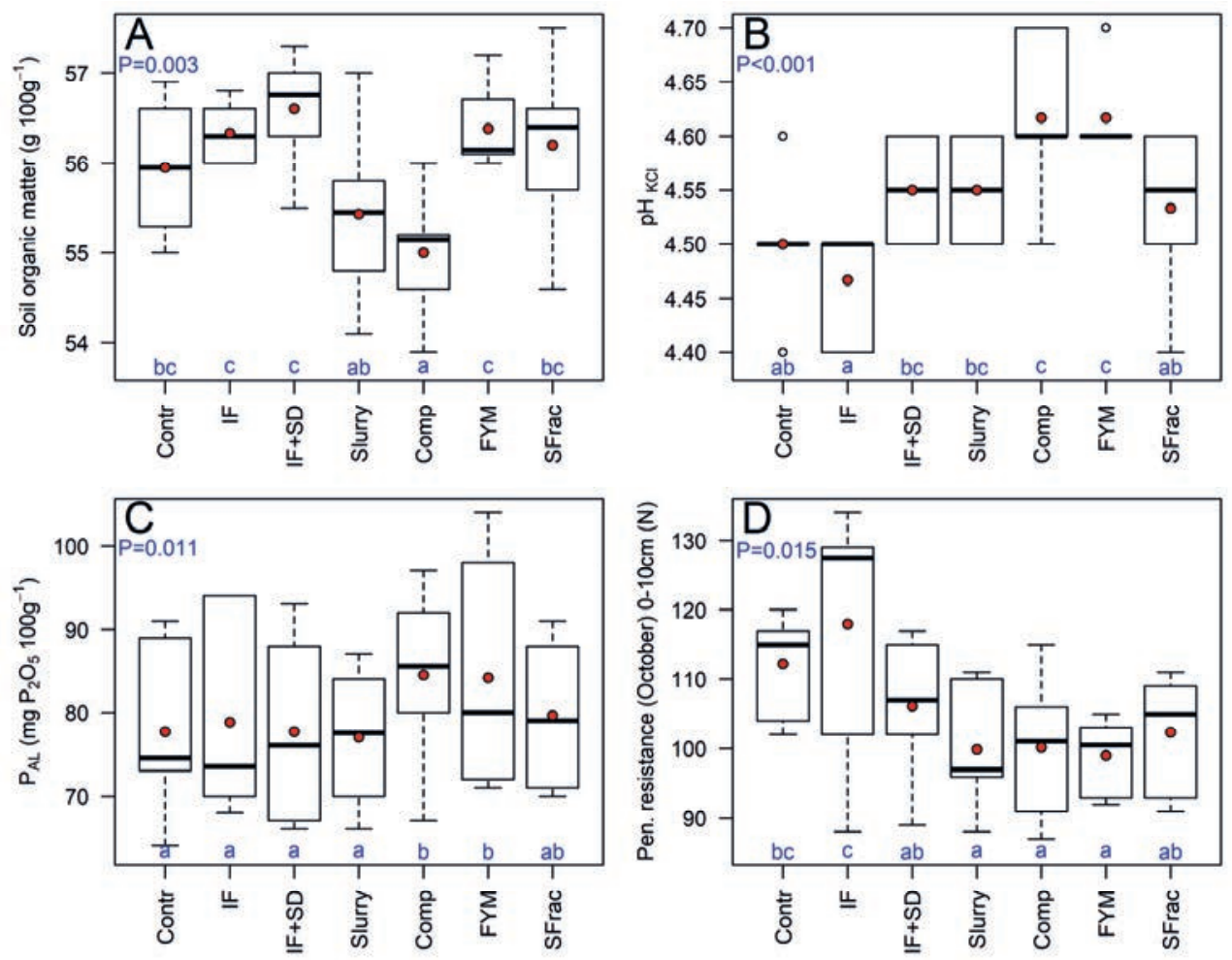

Figure 5.3 Effects of fertilizers on soil chemical and physical parameters: soil organic matter content (SOM; A), $\mathrm{pH}_{\mathrm{KCl}}(\mathrm{B}), \mathrm{P}_{\mathrm{AL}}(\mathrm{C})$ and penetration resistance in 0-10 cm (October) (D). More soil chemical and physical data in Tables S5.3 and S5.4. Treatment codes, figure explanation: see Fig. 5.1. 
(4.47) and the highest values in FYM and Comp (4.62). The latter treatments had also the highest $\mathrm{P}_{\mathrm{AL}}$.

Effects on penetration resistance were found in October only: in 0-10 cm, values were highest in IF and lowest with the organic fertilizers (Fig. 5.3D). Soil moisture was highest in FYM and SFrac in April as well as in October (Table S5.4). Other differences in soil physical aspects were observed in the 10-25 cm layer, where Slurry and Comp had a higher percentage of crumb structures and a high root density.

\subsubsection{Herbage production and botanical composition}

The herbage yields were affected by the treatments (Fig. 5.4A). Compared to the unfertilized control, the fertilizers increased herbage DM yield by c. $10 \%$ but the type of fertilizer did not matter. This was different for the herbage $\mathrm{N}$ yield which was $302 \mathrm{~kg} \mathrm{~N}$ $\mathrm{ha}^{-1} \mathrm{yr}^{-1}$ in the unfertilized plots, was not significantly higher in any of the four organic fertilizer treatments (Slurry, Comp, FYM and SFrac), but increased by $16-20 \%$ in IF and IF+SD as compared to Contr (Fig. 5.4B). Herbage DM and N yields showed correlations with the fertilizer $\mathrm{C}$ and mineral inputs and $\mathrm{C}: \mathrm{N}$ ratio that were opposite for the first two harvests compared to the last two harvests, and also for $\mathrm{N}_{\min }$ versus $\mathrm{N}_{\text {org }}$ input (Table 5.5). The average herbage $\mathrm{N}$ content was higher in IF+SD and lower in all organic fertilizers as compared to Contr (Fig. 5.4C). Apparent $\mathrm{N}$ recovery ranged between -0.01 and $+0.48 \mathrm{~kg}$ N.kg $\mathrm{N}^{-1}$ (with a large variation within treatments) and was highest in IF and IF+SD, intermediate in Slurry and lowest for the remaining organic fertilizers (Fig. 5.4D). There was no treatment effect on the soil cover percentage or species number of grasses or dicotyledons (Table S5.6), nor on soil cover of individual plant species (data not shown).

Table 5.5 Pearson correlations ( $r ; n=42$ ) of the fertilizer input of $C, N_{\text {total }}, N_{\text {mineral }}, N_{\text {organic }}, P$ and C:N ratio (average of 2013-2015) with herbage dry matter (DM) or nitrogen (N) yields in 2015 per harvest $(\mathrm{H} 1-\mathrm{H} 4)$ and year total across all treatments. Only significant correlations are presented: standard font: $P \leq 0.05$; bold: $P \leq 0.001$.

\begin{tabular}{|c|c|c|c|c|c|c|c|c|c|c|}
\hline \multirow[b]{2}{*}{ Fertilizer input } & \multicolumn{5}{|c|}{ Herbage DM yield } & \multicolumn{5}{|c|}{ Herbage $\mathrm{N}$ yield } \\
\hline & $\mathrm{H} 1$ & $\mathrm{H} 2$ & $\mathrm{H} 3$ & $\mathrm{H} 4$ & Total & $\mathrm{H} 1$ & $\mathrm{H} 2$ & $\mathrm{H} 3$ & $\mathrm{H} 4$ & Total \\
\hline C & & -0.35 & 0.31 & 0.54 & & & -0.42 & & 0.47 & \\
\hline Total N & 0.53 & & & & 0.53 & & & & 0.31 & \\
\hline Mineral $\mathrm{N}$ & 0.48 & 0.75 & -0.58 & -0.52 & & 0.70 & 0.79 & -0.38 & -0.38 & 0.67 \\
\hline Organic N & & -0.52 & 0.52 & 0.77 & & -0.51 & -0.64 & 0.34 & 0.63 & -0.44 \\
\hline$P$ & & -0.53 & 0.55 & 0.75 & & -0.49 & -0.65 & 0.37 & 0.60 & -0.43 \\
\hline
\end{tabular}



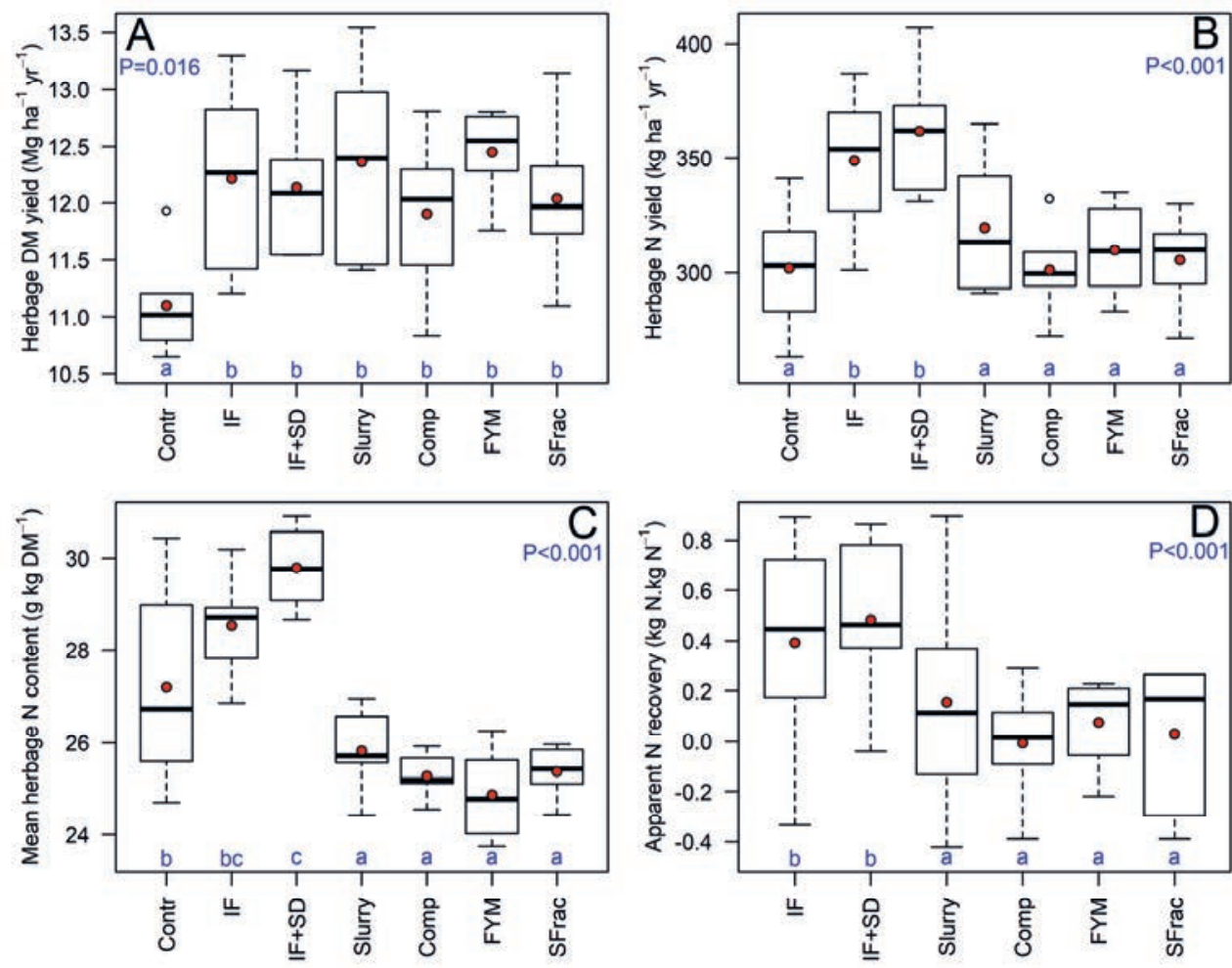

Figure 5.4 Effects of three years of fertilizer treatments on herbage dry matter (DM) yield (A), $N$ yield (B), year mean $\mathrm{N}$ content $(\mathrm{C})$ and apparent $\mathrm{N}$ recovery (D). Effects per individual harvests and on $\mathrm{DM}$ contents, see Table S5.5. Treatment codes, figure explanation: see Fig. 5.1.

\subsection{Discussion}

\subsubsection{Support of biodiversity}

\subsubsection{Earthworms}

Earthworms are considered an important food source for predators in higher trophic levels such as badgers and (meadow) birds (Macdonald, 1983; Muldowney et al., 2003; Onrust and Piersma, 2017; Vickery et al., 2001), and also benefit lower trophic level organisms through their significant contribution to soil structure formation, pore distribution and food resources availability (Brown, 1995; Loranger et al., 1998). Abundance and biomass effects of fertilizers on earthworms and other soil invertebrates are therefore relevant for the ecosystem service of support of biodiversity even if there is no effect on their species 
richness. Also their effects for water regulation are important (Deru et al., 2018a). In line with the first hypothesis, the earthworm biomass was largest in the grasslands fertilized with solid fraction (Fig. 5.1C), which is the fertilizer with the highest organic matter input (> $6 \mathrm{Mg} \mathrm{ha}^{-1} \mathrm{yr}^{-1}$ ) (Table 5.1). This effect is attributed to larger numbers of epigeic earthworms (detritivorous) (Fig. 5.1B) and of the endogeic (geophagous) species $A$. chlorotica (Table S5.1).

In mineral soils, no or weak effects of organic fertilizer on earthworms have been found in grasslands (Edwards and Lofty, 1982; Van Eekeren et al., 2009a). This was explained by the high availability of food (root litter and other plant residues) in productive grassland in comparison to the amount of organic matter added with fertilizers. In these studies, earthworm sampling occurred in autumn to exclude short term fertilizer effects. In contrast, we were mainly interested in earthworm counts in the spring, i.e. coinciding with the presence of earthworm feeding meadow birds. Sampling (April) was close to the first of the two yearly moments of fertilizer application (Table S5.7). This may explain the negative effect on total earthworm numbers measured in IF (Fig. 5.1A) and on epigeic earthworms in Slurry (Fig. 5.1B) due to physical damage (De Goede et al., 2003), and the quick response of the rapidly reproducing epigeic earthworms (Bouché, 1977) to SFrac (Fig. 5.1B). Our peat soil contained much more SOM and higher numbers of earthworms than the experiments of Edwards and Lofty (1982) and Van Eekeren et al. (2009), but positive effects of SFrac were still measured. This material was thus of added nutritional value for the earthworm population. This is in line with experimental evidence that for earthworms $\mathrm{C}$ availability is generally limiting, irrespective of the SOM content (Tiunov and Scheu, 2004) and that earthworms are mostly resource limited (Salamon et al., 2006). Leroy et al. (2008) illustrated that C availability for earthworms also depends on the quality of the added organic material. In an experiment with organic fertilizers, all applied with the same $\mathrm{C}$ input and in which $\mathrm{N}$ effects were excluded, earthworm abundance increased with organic fertilizers compared to the control, and the increase in this study was higher with farmyard manure or slurry than with compost. The authors proposed that humification and stabilization in the composting process reduced the nutritional value of the organic matter compared to the less humified farmyard manure. Combined with the different $C$ application rates in our experiment, this may be the reason of the lack of differences in earthworm abundance and biomass between Slurry (low C input, high nutritional value), Comp (moderate $\mathrm{C}$ input, low nutritional value) and FYM (high C input, 
moderate nutritional value) (Fig. 5.1). Similarly, the same C input of IF+SD and Comp but a higher number of epigeic earthworms in IF+SD (Fig. 5.1B) indicates that lignin-rich but nonhumified material may be of greater nutritional value for those earthworms, at least when combined with mineral N. Inorganic fertilizer, with (IF+SD) or without (IF) sawdust, resulted in a high proportion of juvenile epigeic earthworms (Fig. 5.1D). This may be related to the similar increase in microbial biomass (Fig. 5.2A), as earthworms also are microbial feeders (Bonkowski et al., 2000; Curry and Schmidt, 2007). Apparently, the positive effect of mineral $\mathrm{N}$ on the reproduction of epigeic earthworms influenced the whole population (including adults) only in IF+SD and in SFrac, thus where (organic) N addition was combined with (large) amounts of $\mathrm{C}$.

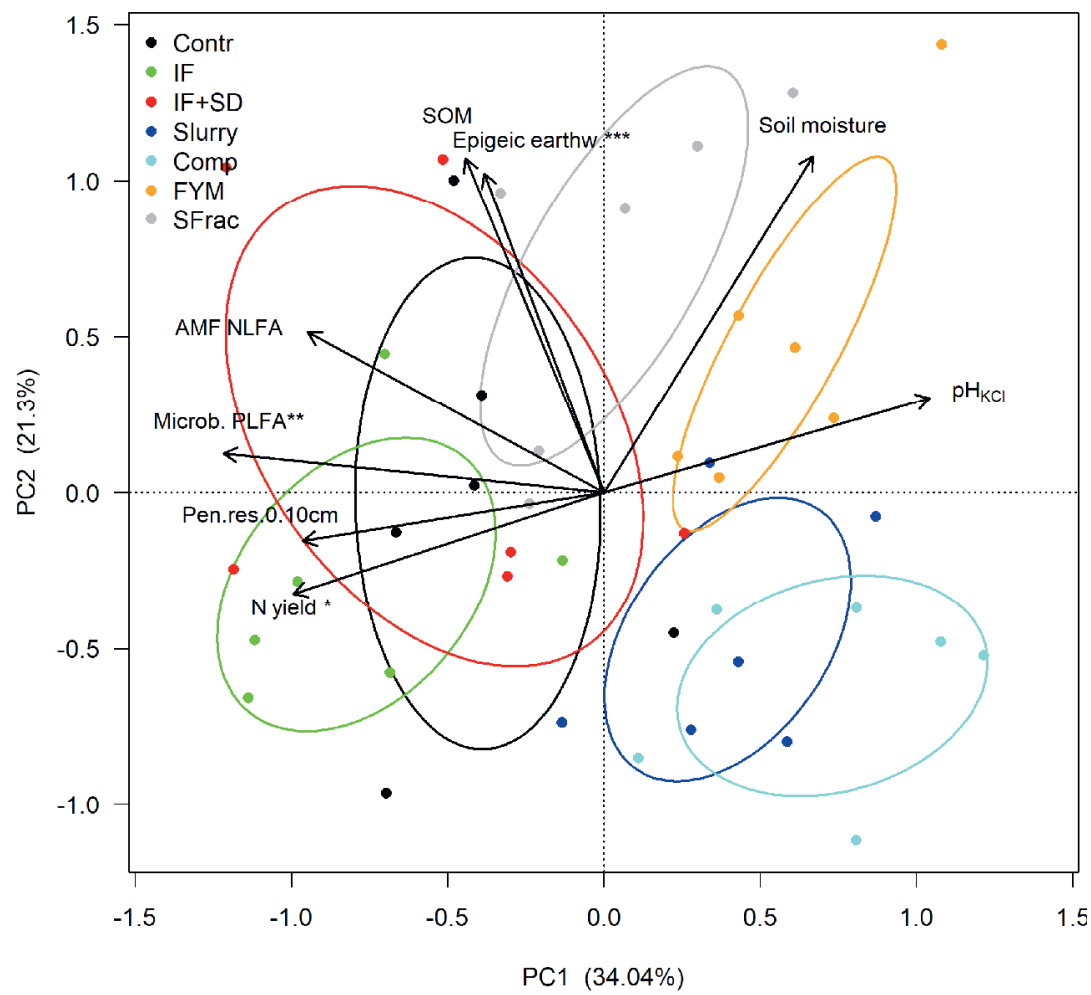

Figure 5.5 Axes 1 and 2 of a principal component analysis (PCA) of the measured parameters (soil biological, chemical and physical, and grass $\mathrm{N}$ yield) that showed a significant treatment effect. Parameters were omitted from the figure when they had a very short arrow (indicating low correlation with the two first principal components, which was the case for $\mathrm{P}_{\mathrm{AL}}$ ). *similar for grass DM yield; **similar for other PLFA parameters; ${ }^{* * *}$ similar for total number of earthworms. Ellipses calculated at 50\% confidence. Treatment codes: see Fig. 5.1. 
Other factors than the organic matter input and the timing of measurement that may have influenced the earthworm populations in our experiment are changes in soil acidity (Curry, 2004; Ma et al., 1990; McCallum et al., 2016; Van Eekeren et al., 2009a) and differences in crop growth and associated amount of crop residues. However, the abundance of earthworms was not related with soil $\mathrm{pH}_{\mathrm{KCl}}$ (Fig. 5.5; Table 5.3), probably due to the narrow range of values $(4.47-4.62)$, nor with grass $\mathrm{N}$ or DM yield, possibly because of the limited yield effects (Fig. 5.4). Instead, earthworm numbers were positively correlated with SOM and the SOM-related parameters $\mathrm{N}_{\text {total }}$ and $\mathrm{P}_{\text {total }}$ (Fig. 5.5; Table 5.3), in accordance with the above mentioned view of resource limitation (Salamon et al., 2006).

\subsubsection{Soil microbial abundance and community structure}

The increased microbial PLFA after three years of mineral $\mathrm{N}$ application (IF and IF+SD) compared to the plots with organic fertilizers (Fig. 5.2A) indicates that in the peat soil the microbial community was limited by the availability of mineral $\mathrm{N}$ rather than by $\mathrm{C}$ or by organically bound nutrients. This is also illustrated by the positive correlation between total microbial PLFA and mineral N input (Table 5.4). Similarly, Song et al. (2017) found positive effects of comparable amounts of mineral $\mathrm{N}$ on microbial PLFA in permafrost peat, with regularly added $\mathrm{N}$ during the growing season. In our case, $\mathrm{N}$ was applied the start of the growing season and PLFA measured at the end was still high, which indicates that changes in PLFA were persistent. This lasting effect is in line with previous findings in grassland soils (Bardgett and McAlister, 1999). In contrast to our results, a long term fertilization experiment on a mineral soil (Börjesson et al., 2012) showed that PLFA, also measured at the end of the growing season, was especially increased in plots treated with organic fertilizers, and less by addition of mineral $\mathrm{N}$. This difference may be explained by the lower C limitation to microbial growth in peat soil, compared to mineral soil, due to its high SOM content. This may also explain the reduced microbial PLFA concentration in Slurry and Comp, in which a decrease in SOM was observed (Fig. 5.3A).

In peat grasslands, the microbial community is generally dominated by bacteria (Deru et al., 2018a; Kechavarzi et al., 2010; Van Dijk et al., 2004). In our study, IF increased the relative abundance of bacterial PLFA further and Comp reduced it (Fig. 5.2C), leading to a negative correlation between mineral $\mathrm{N}$ input and fungal:bacterial ratio (Table 5.4). It is 
well established that bacteria benefit more from high (mineral) $\mathrm{N}$ availability (Bardgett and McAlister, 1999), in our experiment occurring in IF and IF+SD, and that fungi are better adapted to environments with more stabilized and recalcitrant organic matter (Paterson et al., 2008), occurring in Comp and IF+SD (Clocchiatti et al., 2020; Senesi and Plaza, 2007). In absolute amounts, fungal PLFA was increased only in the treatment with sawdust (Table S5.2), which indicates that fungi benefited from input of lignin-rich $C$ combined with mineral N, which is in line with the findings of Clocchiatti et al. (2020). In this treatment, N immobilization in soil may have occurred due to the high C:N ratio of sawdust (Gad et al., 2015). However, our results with high grass $N$ uptake (Fig. 5.4B), ANR (Fig. 5.4D) and increased arbuscular mycorrhizal NLFA (Fig. 5.2B) suggest that this did not compromise grass yield because of increased symbiotic nutrient acquisition. Similar processes may have occurred in Contr and Sfrac, both with potential nutrient limitation either due to lack of $\mathrm{N}$ input (Contr) or $\mathrm{N}$ immobilization (Sfrac) (Peters and Jensen, 2011) and with higher AMF NLFA concentration. This could explain the lack of depressive effects in Contr and of Sfrac on herbage $\mathrm{N}$ yields compared to the (other) organic fertilizers with lower $\mathrm{C}: \mathrm{N}$ ratios.

Also changes in the amount of Gram-positive and Gram-negative bacteria may be induced by treatments with fertilizers differing in C quality (Börjesson et al., 2012). It has been proposed that Gram-positive bacteria are related to recalcitrant SOM, and Gramnegative bacteria to fresh plant material (Kramer and Gleixner, 2008), and that their ratio can therefore be used as an indicator of C availability for soil microbes (Fanin et al., 2019). Our results show an increase in both Gram-positive and Gram-negative bacteria in the soils treated with inorganic N fertilizer (IF and IF+SD) (Table 5.4; Table S5.2), in line with the overall stimulating effect on the microbial community. The Gram-positive to Gramnegative ratio was highest in the treatment with SFrac (Fig. 5.2D) which seems to contradict the above cited literature as this treatment realized the highest input of C (Table 5.1), that was composed of relatively young organic material compared to the peat. However, an increase in microbial biomass after addition of solid fraction to soil is found to be short lived (Guerrero et al., 2007) and C decomposition rates may be high (Peters and Jensen, 2011). Therefore, the higher Gram-positive to Gram-negative ratio in Sfrac with lack of influence on the microbial abundance or fungal:bacterial PLFA ratio may indicate that (possible) short-term effects had faded away at the time of sampling and that long term effects were limited. Together with these observations, the lack of difference in the Gram-positive to Gram-negative ratio in IF compared to IF+SD points out that in this 
soil with an abundant pool of SOM, the type of bacteria is not strongly influenced by the (recalcitrance of the) added C.

\subsubsection{Water and climate regulation}

\subsubsection{Water regulation}

We hypothesized that fertilizers with a high C:N ratio and positive effects on soil biota would increase the root density, soil porosity and water infiltration, important for the ecosystem service of water regulation. The range in earthworm abundance created by the fertilizer treatments (270-480 worms $\mathrm{m}^{-2}$ ), the earthworm biomass and proportion of adults (Table S5.1) were similar to that between dairy and semi-natural grasslands on peat (Deru et al., 2018a) where positive effects of earthworm abundance, macropores, root density and soil crumbs on water infiltration were found. However, in the present study the influence of fertilizers on root density, soil crumbliness or water infiltration rate was marginal or not significant (Table S5.4). We therefore conclude that the type of fertilizer, when applied at the moderate rates used in this study and for a period of three years, influenced the earthworm community but had not enough cumulative effects on soil physical properties to influence the water infiltration as well.

\subsubsection{Climate regulation}

Increasing SOM can be seen as a climate mitigation measure if this leads to a decrease in atmospheric $\mathrm{CO}_{2}$ (Minasny et al., 2017). We hypothesized that fertilizers with high $\mathrm{C}$ input and $\mathrm{C}: \mathrm{N}$ ratio could influence SOM. For peat soils, reducing the ongoing SOM decomposition may also decrease soil subsidence. As our SOM measurements were in a fixed soil layer (top $10 \mathrm{~cm}$ ), differences do not provide information on effects on the total SOM pool of the peat layer. For example, the decrease of SOM in the case of Comp by $1 \%$, as compared to Contr, may be explained by a dilution effect (Rühlmann et al., 2006) because the applied compost contained only $44 \%$ organic matter (Table 5.1: $56 \%$ ash), against $56 \%$ in the peat soil itself.

Besides direct $\mathrm{C}$ input and dilution effects, changes in soil chemistry $(\mathrm{pH}, \mathrm{P}$ availability, HWC) and biology (microbial biomass and community structure, earthworms) provide indirect information on potential changes in SOM decomposition (Bergman et al., 1999; Brouns et al., 2016; Didden et al., 1994; Fierer and Jackson, 2006; Lubbers et al., 2017; 
Rousk et al., 2011) that is discussed hereafter. Concerning soil chemistry, changes in soil acidity were significant but small, and only weakly related with microbial parameters (Fig. 5.3B; Table 5.4). Also HWC, a pool of labile $C$ which is seen as a sensitive indicator for SOM decomposition dynamics (Deru et al., 2018a; Ghani et al., 2003), was not influenced by treatments (Table S5.3). However, in the longer term or at higher fertilization rates, C inputs may be higher and SOM dynamics may be more influenced by changes in soil $\mathrm{pH}, \mathrm{P}$ availability and (micro)biology. Based on our results, the following potential fertilizer effects on SOM dynamics in fertilized peat grasslands can be proposed: (1) Inorganic N fertilizer tends to increase microbial biomass in favor of bacteria, which is potentially increasing peat decomposition. The decrease in $\mathrm{pH}$ caused by the inorganic $\mathrm{N}$ fertilizer may mitigate this process, but not if farmers control the soil acidity by liming. (2) Organic fertilizers increased $\mathrm{pH}$ and $\mathrm{P}_{\mathrm{AL}}$ (especially Comp and FYM), potentially increasing SOM decomposition. This possible effect should still be investigated, also in relation with the amount of new added organic matter by the fertilizer. (3) The large amounts of organic matter added with Sfrac had little effects on the microbial and soil chemical properties that potentially increase SOM decomposition, but increased earthworm abundance and biomass which may affect SOM decomposition and greenhouse gas emission (Lubbers et al., 2017).

\subsubsection{Herbage production and $\mathrm{N}$ uptake}

All fertilizers increased the herbage DM yield similarly compared to the control, but the $\mathrm{N}$ yield was higher only when inorganic $N$ fertilizer had been applied (IF and IF+SD, Fig. 5.4). Moreover, the apparent $\mathrm{N}$ recovery of inorganic $\mathrm{N}$ fertilizer was in the lower range of what has been measured in drained peat grasslands (Deru et al., 2019; Vellinga and André, 1999). These weak effects of both the organic and inorganic fertilizers can be explained by the low application rates $\left(120 \mathrm{~kg} \mathrm{~N} \mathrm{ha}^{-1} \mathrm{yr}^{-1}\right)$ used in this experiment, in combination with the, even for peat soils, high soil $\mathrm{N}$ supply (302 $\mathrm{kg} \mathrm{N} \mathrm{ha}^{-1} \mathrm{yr}^{-1}$ ) (Deru et al., 2019; Pijlman et al., 2020; Vellinga and André, 1999). The absence of a decrease in the proportion of productive grasses in the third year after cessation of $\mathrm{N}$ fertilizing in the control plots (data not shown) supports this explanation.

Our observation that the organic fertilizers did not increase herbage $\mathrm{N}$ yield may be caused by non-synchrony during the growing season between the mineralization of the 
applied organic $\mathrm{N}$ and the grass $\mathrm{N}$ demand. At the level of individual harvests within the growing season, the fertilizers with (almost) $100 \%$ mineral $N$ (IF and IF+SD) resulted in the highest $\mathrm{N}$ yields at the first two harvests and no effects later on. In contrast, the organic fertilizers (80-95\% organic $N$ ) had no effects in the first two harvests but increased $\mathrm{N}$ yields later on, as compared to the treatments with inorganic $\mathrm{N}$ fertilizer (Table S5.5). This resulted in a positive correlation of $\mathrm{N}$ yield with the amount of applied mineral $\mathrm{N}$ for the first two harvests, and with the amount of organic $\mathrm{N}$ for the last harvests (Table 5.5). This supports our hypothesis that fertilizers with low $\mathrm{C}: \mathrm{N}$ ratio and high mineral $\mathrm{N}$ content would increase herbage yield. As discussed in section 5.4.1.2., N immobilization in IF+SD and SFrac (both high C:N ratio) was possibly compensated by symbiotic nutrient acquisition by increased abundance of mycorrhizal fungi. We conclude that grass $\mathrm{N}$ uptake was limited by the availability of mineral $\mathrm{N}$ in the treatments with organic fertilizers, due to low application rates and possible $\mathrm{N}$ immobilization in soil, resulting in low apparent $\mathrm{N}$ recovery (Fig. 5.4D). Recent studies in drained peat grasslands indicate that the soil $\mathrm{N}$ supply depends on the mineralization of organic N from the decomposing SOM, which is mainly temperature-driven (Pijlman et al., 2020) and, in addition, may be reduced by low water availability in summer due to water repellency (Deru et al., 2019). Those studies were carried out by comparing non-fertilized and inorganic $\mathrm{N}$-fertilized plots only. The present experiment including organic fertilizers indicates that the additional $\mathrm{N}$ availability from mineralization of fertilizer organic $\mathrm{N}$ is low.

Our study in drained peat grassland with a high soil $\mathrm{N}$ supply was carried out at low fertilization rate in comparison with mainstream management practice. A practical outcome for agri-environmental grasslands in this soil type is that herbage DM yield is similarly increased by fertilizers applied in the first half of the growing season independent of their chemical composition. From a meadow bird perspective, the sward should not be too dense in the spring to facilitate chick movement and insect picking. Our results confirm that inorganic $\mathrm{N}$ fertilizer is less suitable in these grasslands as it results in the fastest growth in the first harvests due to high $\mathrm{N}$ uptake (Table S5.5). The use of organic fertilizers led to intermediate grass growth compared to the control and inorganic $\mathrm{N}$ fertilizers. 


\subsection{Conclusions and implications for practice}

The three-year field experiment provided new insights in the value of inorganic and organic fertilizers on peat grasslands for the regeneration of supporting, regulating and provisioning soil ecosystem services.

Concerning the ecosystem service support of biodiversity, indicated by changes in earthworm and microbial communities that are important for organisms in other trophic levels (below and above ground) as well, we conclude that (epigeic) earthworm abundance in the spring is increased with a large input of organic matter that is not strongly humified. Solid fraction of cattle slurry appears to be an appropriate alternative for farmyard manure in grasslands with biodiversity goals due to its high $\mathrm{C}: \mathrm{N}$ ratio and positive effects on earthworms. The combination of fresh and lignin-rich organic matter with mineral $\mathrm{N}$ (here: sawdust and inorganic $\mathrm{N}$ fertilizer) promotes the reproduction of epigeic earthworms. Bacterial abundance was increased by inorganic $\mathrm{N}$ fertilizers, and less by the amount and quality of added $\mathrm{C}$ due to the abundance of SOM in peat. Inorganic and organic $\mathrm{N}$ fertilization reduced the abundance of arbuscular mycorrhiza except where large quantities of $\mathrm{C}$ were added (solid fraction) or where the added $\mathrm{C}$ was lignin-rich (sawdust + inorganic $\mathrm{N}$ fertilizer).

The ecosystem services water regulation and climate regulation, indicated by changes in soil physical and chemical properties in the topsoil, were not strongly influenced by fertilizers due to the combination of relatively low fertilization rate and high SOM content of the peat. In the longer term or at higher fertilization rates, $\mathrm{C}$ inputs may be higher and SOM dynamics may be more influenced by the changes in soil $\mathrm{pH}, \mathrm{P}$ availability and (micro)biology than found in this fertilization experiment. Such indirect effects should therefore be investigated with specific measurements of the decomposition of both the added organic matter and the older peat over a deeper soil layer.

For the ecosystem service herbage production, we conclude that grass DM yield was similarly influenced by fertilizers but that $\mathrm{N}$ yield was higher than the unfertilized control only when the applied $\mathrm{N}$ was in mineral form. We hypothesize that the marginal yield effect and low apparent $\mathrm{N}$ recovery of organic fertilizers was caused by a combination of the low application rate (120 $\left.\mathrm{kg} \mathrm{N} \mathrm{ha}^{-1} \mathrm{yr}^{-1}\right)$, low mineral $\mathrm{N}$ content, in some cases humified organic matter and $\mathrm{N}$ immobilization, and a high soil $\mathrm{N}$ supply. 
We conclude that the use of organic fertilizers with high and non-humified organic matter content such as solid fraction can be part of a regeneration strategy of ecosystem services in peat grasslands. The solid fraction of cattle manure is appropriate as a substitute for farmyard manure for meadow bird conservation purposes in such soils. $A$ strategic timing of early application of solid fraction (to promote epigeic earthworms) and later application of liquid fraction (as mineral $\mathrm{N}$ source for grassland production) is recommended for further investigation.

\section{Acknowledgements}

We thank Frank Lenssinck for his contributions to the research project. Coen ter Berg, Riekje Bruinenberg, Hans Dullaert, Nyncke Hoekstra, Evertjan Dijk, Hannah te Velde, René Groenen and Karel van Houwelingen are acknowledged for assisting in field work, and An Vos, Wim Dimmers, Jan Bovenschen and Arriënne Matser for analyzing HWC and PLFA. Maaike van Agtmaal is acknowledged for her assistance in the data analysing.

\section{Funding}

This work was part of the projects "Bodemindicatoren voor duurzaam bodemgebruik in de veenweiden" and "Winst en weidevogels". These projects were funded by Stichting Kennisontwikkeling en kennisoverdracht Bodem, the Provinces Noord-Holland, ZuidHolland and Utrecht, the Dutch Ministry of Infrastructure and Water Management, the Dutch Ministry of Economic Affairs, the Dairy Board (ZuiveINL), LTO Noord Fondsen, WUR Environmental Research and the Foundation for Applied Water Research (STOWA). 


\section{Appendix: Supplementary material}

Table S5.1 Earthworm numbers, biomass and diversity, and insect larvae numbers, in drained peat grassland in April 2015. Treatment codes: Contr: control, IF: inorganic N fertilizer, IF+SD: inorganic $N$ fertilizer and sawdust, Slurry: cattle slurry manure, Comp: compost, FYM: farmyard manure, SFrac: solid fraction of cattle slurry manure. $P$-values $\leq 0.05$ in bold. Per parameter, two means with the same letter are not significantly different $(\alpha=0.05)$.

\begin{tabular}{|c|c|c|c|c|c|c|c|c|c|c|}
\hline \multirow[b]{2}{*}{ Parameter } & \multicolumn{3}{|c|}{$P$} & \multirow[b]{2}{*}{ IF } & \multirow[b]{2}{*}{$\mathrm{IF}+\mathrm{SD}$} & \multirow[b]{2}{*}{ Slurry } & \multirow[b]{2}{*}{ Comp } & \multirow[b]{2}{*}{ FYM } & \multirow[b]{2}{*}{ SFrac } & \multirow[b]{2}{*}{ I.s.d. } \\
\hline & Unit & value & Contr & & & & & & & \\
\hline \multicolumn{11}{|l|}{ Earthworms } \\
\hline Species number & $\mathrm{n}$ & 0.516 & 4.2 & 3.3 & 4.2 & 4 & 3.5 & 4 & 4.3 & 1.1 \\
\hline Total number ${ }^{\dagger}$ & $\mathrm{n} \mathrm{m}^{-2}$ & 0.010 & $355 b c$ & $271 \mathrm{a}$ & $361 a b c$ & $308 a b$ & $305 a b$ & $340 a b$ & $480 \mathrm{c}$ & + \\
\hline Epigeic & $\mathrm{n} \mathrm{m}^{-2}$ & 0.002 & $146 a b$ & $141 \mathrm{ab}$ & $181 \mathrm{bc}$ & 96 a & $105 \mathrm{a}$ & $140 a b$ & $230 \mathrm{c}$ & 62 \\
\hline Endogeic & $\mathrm{n} \mathrm{m}^{-2}$ & 0.269 & 210 & 128 & 176 & 213 & 199 & 200 & 249 & 93 \\
\hline \% epigeic & $\%$ & 0.094 & 41 & 53 & 50 & 33 & 35 & 43 & 50 & 16 \\
\hline Adults & $\mathrm{n} \mathrm{m}^{-2}$ & 0.040 & $169 a b$ & 129 a & $169 a b$ & $158 a b$ & $123 a$ & $121 \mathrm{a}$ & $202 b$ & 54 \\
\hline Juveniles & $\mathrm{n} \mathrm{m}^{-2}$ & 0.139 & 156 & 117 & 169 & 133 & 167 & 192 & 240 & 87 \\
\hline$\%$ adults & $\%$ & 0.247 & 47 & 48 & 47 & 50 & 41 & 35 & 44 & 13 \\
\hline Juv. epigeic & $\mathrm{n} \mathrm{m}^{-2}$ & 0.047 & $65 \mathrm{abc}$ & $73 a b c$ & 96 bc & $36 a b$ & $50 \mathrm{ab}$ & $73 a b c$ & $113 \mathrm{c}$ & 48 \\
\hline$\%$ ad. epigeic & $\%$ of ad & 0.922 & 42 & 40 & 43 & 34 & 36 & 45 & 45 & 21 \\
\hline \% juv. epigeic & $\%$ of juv & 0.025 & $40 a b c$ & $60 c$ & $57 c$ & $28 \mathrm{a}$ & $33 a b$ & $40 a b c$ & $54 \mathrm{bc}$ & 21 \\
\hline L. rubellus & $\mathrm{n} \mathrm{m}^{-2}$ & 0.007 & $138 a b c$ & $123 a b$ & $169 \mathrm{bc}$ & $88 \mathrm{a}$ & 96 a & $123 a b$ & $194 \mathrm{c}$ & 57 \\
\hline A. chlorotica & $\mathrm{n} \mathrm{m}^{-2}$ & 0.062 & $60 a b$ & $31 \mathrm{a}$ & 35 a & $63 a b$ & $69 a b$ & $44 \mathrm{a}$ & $102 \mathrm{~b}$ & 46 \\
\hline A. caliginosa & $\mathrm{n} \mathrm{m}^{-2}$ & 0.724 & 108 & 81 & 108 & 100 & 117 & 131 & 115 & 57 \\
\hline O. lacteum & $\mathrm{n} \mathrm{m}^{-2}$ & 0.114 & 8 & 8 & 17 & 31 & 4 & 8 & 13 & 19 \\
\hline n.d. & $\mathrm{n} \mathrm{m}^{-2}$ & 0.064 & 30 & 25 & 23 & 17 & 15 & 28 & 38 & 15 \\
\hline Total biomass & $\mathrm{g} \mathrm{m}^{-2}$ & 0.048 & $128 \mathrm{a}$ & 99 a & $130 a b$ & 120 a & $106 a$ & $113 \mathrm{a}$ & $176 \mathrm{~b}$ & 47 \\
\hline \multicolumn{11}{|l|}{ Insect larvae } \\
\hline Leatherjackets & $\mathrm{n} \mathrm{m}^{-2}$ & 0.247 & 44 & 54 & 46 & 29 & 38 & 63 & 121 & 79 \\
\hline Wireworms & $\mathrm{n} \mathrm{m}^{-2}$ & 0.039 & $44 \mathrm{a}$ & $63 a b$ & $65 a b$ & $98 \mathrm{~b}$ & $46 a$ & $104 \mathrm{~b}$ & $113 \mathrm{~b}$ & 51 \\
\hline
\end{tabular}

${ }^{\dagger}$ parameter data were log-transformed prior to ANOVA and posthoc test. Presented means are untransformed; significance letters are based on I.s.d. calculated on the transformed data. 
Table S5.2 Microbial phospholipid fatty acids (PLFA, nmol g${ }^{-1}$ ) and neutral lipid fatty acids (NLFA) in drained peat grassland after three years of fertilizer treatments, October 2015. Treatment codes: see Table S5.1. AMF: arbuscular mycorrhizal fungi. $P$-values $\leq 0.05$ in bold. Per parameter, two means with the same letter are not significantly different $(\alpha=0.05)$.

\begin{tabular}{lccccccccc}
\hline Parameter & P-value & Contr & IF & IF+SD & Slurry & Comp & FYM & SFrac & I.s.d. \\
\hline Total microbial PLFA & $<.001$ & $83.4 \mathrm{~cd}$ & $124.0 \mathrm{~d}$ & $127.0 \mathrm{~d}$ & $53.3 \mathrm{ab}$ & $52.6 \mathrm{a}$ & $73.0 \mathrm{abc}$ & $83.5 \mathrm{bc}$ & $\dagger$ \\
Bacterial PLFA & $<.001$ & $43.3 \mathrm{a}$ & $71.6 \mathrm{c}$ & $65.7 \mathrm{bc}$ & $27.7 \mathrm{a}$ & $27.6 \mathrm{a}$ & $41.2 \mathrm{a}$ & $45.1 \mathrm{ab}$ & 22.12 \\
Saprotr. fungal PLFA & $\mathbf{0 . 0 0 3}$ & $1.53 \mathrm{ab}$ & $1.60 \mathrm{bc}$ & $1.89 \mathrm{c}$ & $1.19 \mathrm{a}$ & $1.22 \mathrm{a}$ & $1.27 \mathrm{ab}$ & $1.33 \mathrm{ab}$ & 0.35 \\
ratio fung.:bact. PLFA & $\mathbf{0 . 0 0 3}$ & $0.036 \mathrm{~b}$ & $0.023 \mathrm{a}$ & $0.032 \mathrm{ab}$ & $0.043 \mathrm{bc}$ & $0.048 \mathrm{c}$ & $0.034 \mathrm{~b}$ & $0.034 \mathrm{~b}$ & 0.011 \\
Gram-pos PLFA & $\mathbf{0 . 0 0 2}$ & $29.4 \mathrm{a}$ & $49.5 \mathrm{c}$ & $45.3 \mathrm{bc}$ & $19.7 \mathrm{a}$ & $19.4 \mathrm{a}$ & $29.3 \mathrm{a}$ & $33.4 \mathrm{ab}$ & 15.7 \\
Gram-neg PLFA $^{+}$ & $<.001$ & $2.99 \mathrm{a}$ & $9.72 \mathrm{~b}$ & $8.77 \mathrm{~b}$ & $2.78 \mathrm{a}$ & $3.30 \mathrm{a}$ & $4.68 \mathrm{a}$ & $2.74 \mathrm{a}$ & 3.68 \\
ratio G-pos:G-neg & $\mathbf{0 . 0 1 9}$ & $21.1 \mathrm{bc}$ & $7.0 \mathrm{ab}$ & $5.4 \mathrm{a}$ & $14.3 \mathrm{ab}$ & $13.1 \mathrm{ab}$ & $6.4 \mathrm{ab}$ & $59.6 \mathrm{c}$ & $\dagger$ \\
AMF NLFA $^{\dagger}$ & $<.001$ & $1.04 \mathrm{e}$ & $0.35 \mathrm{bcd}$ & $0.62 \mathrm{~cd}$ & $0.22 \mathrm{abc}$ & $0.12 \mathrm{a}$ & $0.16 \mathrm{ab}$ & $0.50 \mathrm{~d}$ & + \\
Actinomycetes PLFA $^{+}$ & 0.103 & 3.84 & 3.95 & 3.54 & 2.04 & 1.55 & 2.04 & 3.17 & 2.02 \\
\hline
\end{tabular}

${ }^{\dagger}$ parameter data were log-transformed prior to ANOVA and posthoc test. Presented means are untransformed; significance letters are based on I.s.d. calculated on the transformed data.

Table S5.3 Soil chemical parameters in drained peat grassland after three years of fertilizer treatments, October 2015. Treatment codes: see Table S5.1. $P$-values $\leq 0.05$ in bold. Per parameter, two means with the same letter are not significantly different $(\alpha=0.05)$.

\begin{tabular}{|c|c|c|c|c|c|c|c|c|c|c|}
\hline Parameter & Unit & $P$-value & Contr & IF & $\mathrm{IF}+\mathrm{SD}$ & Slurry & Comp & FYM & SFrac & I.s.d. \\
\hline$\overline{\text { SOM }}$ & g. $100 \mathrm{~g}^{-1}$ & 0.003 & $56.0 \mathrm{bc}$ & $56.3 \mathrm{c}$ & $56.6 \mathrm{c}$ & $55.4 \mathrm{ab}$ & $55.0 \mathrm{a}$ & $56.4 \mathrm{c}$ & $56.2 b c$ & 0.8 \\
\hline$C_{\text {total }}$ & g. $100 \mathrm{~g}^{-1}$ & 0.217 & 30.9 & 31.3 & 31.2 & 30.6 & 30.9 & 31.4 & 31.3 & 0.5 \\
\hline HWC & $\mu \mathrm{g} \mathrm{C.} \cdot \mathrm{g}^{-1}$ & 0.291 & 9883 & 10319 & 10779 & 10510 & 10304 & 10895 & 10639 & 869 \\
\hline $\mathrm{N}_{\text {total }}$ & g. $100 \mathrm{~g}^{-1}$ & 0.191 & 2.66 & 2.69 & 2.66 & 2.62 & 2.64 & 2.66 & 2.68 & 0.06 \\
\hline$P_{\text {total }}$ & $\mathrm{mg} \mathrm{P}_{2} \mathrm{O}_{5} .100 \mathrm{~g}^{-1}$ & 0.277 & 960 & 954 & 944 & 938 & 929 & 928 & 953 & 32 \\
\hline $\mathrm{P}_{\mathrm{AL}}$ & $\mathrm{mg} \mathrm{P}_{2} \mathrm{O}_{5} .100 \mathrm{~g}^{-1}$ & 0.011 & $78 \mathrm{a}$ & 79 a & $78 \mathrm{a}$ & $77 \mathrm{a}$ & $85 \mathrm{~b}$ & $84 \mathrm{~b}$ & $80 a b$ & 5 \\
\hline $\mathrm{pH}_{\mathrm{KCl}}$ & - & $<.001$ & $4.50 \mathrm{ab}$ & $4.47 \mathrm{a}$ & $4.55 b c$ & $4.55 b c$ & $4.62 \mathrm{c}$ & $4.62 \mathrm{c}$ & $4.53 \mathrm{ab}$ & 0.07 \\
\hline $\mathrm{C}: \mathrm{N}$ ratio & $\mathrm{g} \mathrm{g}^{-1}$ & 0.110 & 11.6 & 11.6 & 11.7 & 11.7 & 11.7 & 11.8 & 11.7 & 0.12 \\
\hline C:SOM & $\mathrm{g} \mathrm{g}^{-1}$ & $0.076^{+}$ & 0.552 & 0.556 & 0.552 & 0.552 & 0.561 & 0.558 & 0.556 & + \\
\hline
\end{tabular}

${ }^{\dagger} \mathrm{P}$-value of the Kruskal Wallis non-parametric test (does not provide a value for I.s.d.) because residuals of C:SOM were not normally distributed (Shapiro-Wilk test $P=0.042$ ), also after transformation. 
Table S5.4 Soil physical parameters in drained peat grassland in the third year of fertilizer treatments, April and October 2015. Treatment codes: see Table S5.1. $P$-values $\leq 0.05$ in bold. Per parameter, two means with the same letter are not significantly different $(\alpha=0.05)$.

\begin{tabular}{|c|c|c|c|c|c|c|c|c|c|c|c|}
\hline Parameter & Layer & Unit & $P$-value & Contr & IF & $\mathrm{IF}+\mathrm{SD}$ & Slurry & Comp & FYM & SFrac & I.s.d. \\
\hline \multicolumn{12}{|l|}{ April 2015} \\
\hline Soil moisture & $0-10 \mathrm{~cm}$ & $\%$ & $<0.001$ & $64.1 \mathrm{a}$ & $64.1 \mathrm{a}$ & $64.6 \mathrm{a}$ & $64.3 \mathrm{a}$ & $64.4 \mathrm{a}$ & $65.4 \mathrm{~b}$ & $65.6 \mathrm{~b}$ & 0.6 \\
\hline \multirow[t]{3}{*}{$\mathrm{PR}^{\ddagger}$} & $0-10 \mathrm{~cm}$ & $\mathrm{~N}$ & 0.563 & 107 & 110 & 111 & 107 & 110 & 100 & 111 & 13 \\
\hline & $10-20 \mathrm{~cm}$ & $\mathrm{~N}$ & 0.785 & 120 & 119 & 121 & 121 & 119 & 119 & 124 & 7 \\
\hline & $20-30 \mathrm{~cm}$ & $\mathrm{~N}$ & 0.279 & 130 & 134 & 122 & 129 & 127 & 130 & 130 & 9 \\
\hline \multicolumn{12}{|l|}{ October 2015} \\
\hline Soil moisture & $0-10 \mathrm{~cm}$ & $\%$ & $<0.001$ & $60.2 \mathrm{a}$ & $60.1 \mathrm{a}$ & $60.5 \mathrm{a}$ & $60.6 \mathrm{a}$ & $60.4 \mathrm{a}$ & $61.8 \mathrm{~b}$ & $61.5 \mathrm{~b}$ & 0.6 \\
\hline \multirow[t]{3}{*}{$\mathrm{PR}^{\ddagger}$} & $0-10 \mathrm{~cm}$ & $\mathrm{~N}$ & 0.015 & 112 bc & $118 \mathrm{c}$ & $106 a b$ & $100 \mathrm{a}$ & $100 \mathrm{a}$ & 99 a & $102 a b$ & 12 \\
\hline & $10-20 \mathrm{~cm}$ & $\mathrm{~N}$ & 0.765 & 124 & 124 & 120 & 122 & 123 & 120 & 123 & 7 \\
\hline & $20-30 \mathrm{~cm}$ & $\mathrm{~N}$ & 0.987 & 127 & 128 & 127 & 127 & 130 & 130 & 127 & 11 \\
\hline Crumb- & $0-10 \mathrm{~cm}$ & $\%$ & 0.180 & 77 & 73 & 68 & 82 & 85 & 72 & 75 & 13 \\
\hline structures & $10-25 \mathrm{~cm}$ & $\%$ & 0.018 & $23 \mathrm{abc}$ & $22 \mathrm{abc}$ & $15 \mathrm{a}$ & $32 \mathrm{c}$ & $30 \mathrm{bc}$ & $20 a b$ & $16 \mathrm{a}$ & 11 \\
\hline \multirow[t]{2}{*}{ Root density } & $0-10 \mathrm{~cm}$ & + & 0.330 & 8.2 & 7.5 & 7.7 & 8.2 & 8.3 & 7.8 & 8.3 & 0.9 \\
\hline & $10-25 \mathrm{~cm}$ & & 0.057 & $6.7 \mathrm{ab}$ & $6.2 \mathrm{a}$ & $6.0 \mathrm{a}$ & $7.0 \mathrm{~b}$ & $7.0 \mathrm{~b}$ & $6.7 a b$ & $6.5 \mathrm{ab}$ & 0.7 \\
\hline Water infiltr. & $\mathrm{mm} / \mathrm{min}$ & & 0.070 & 2.12 & 1.21 & 1.97 & 1.11 & 1.07 & 1.15 & 1.2 & 0.9 \\
\hline
\end{tabular}

${ }^{\dagger}$ Score: lowest density $=0$; highest density $=10$.

${ }^{\ddagger}$ PR: penetration resistance measured with a cone with $2.0 \mathrm{~cm}^{2}$ penetration surface.

Table S5.5 Herbage yield parameters (dry matter (DM) and nitrogen ( $N$ ) yields and DM and $\mathrm{N}$ contents) at four harvests $(\mathrm{H})$ in 2015 and fresh yield of $\mathrm{H} 1$ of drained peat grassland after three years of fertilizer treatments. Treatment codes: see Table S5.1. $P$-values $\leq 0.05$ in bold. Per parameter, two means with the same letter are not significantly different $(\alpha=0.05)$.

\begin{tabular}{|c|c|c|c|c|c|c|c|c|c|c|}
\hline Parameter & Unit & $P$-value & Contr & IF & $\mathrm{IF}+\mathrm{SD}$ & Slurry & Comp & FYM & SFrac & I.s.d \\
\hline DM yield (year) & kg.ha- $a^{-1} y^{-1}$ & 0.016 & $11101 \mathrm{a}$ & $12214 b$ & $12136 \mathrm{~b}$ & $12363 \mathrm{~b}$ & $11908 \mathrm{~b}$ & $12450 \mathrm{~b}$ & $12039 \mathrm{~b}$ & 731 \\
\hline DM yield $\mathrm{H} 1$ & $\mathrm{~kg} \mathrm{ha}^{-1}$ & 0.002 & 3110 a & $4114 \mathrm{c}$ & $4120 \mathrm{c}$ & 3931 bc & $3611 \mathrm{~b}$ & $3930 \mathrm{bc}$ & 3726 bc & 478 \\
\hline $\mathrm{DM}$ yield $\mathrm{H} 2$ & $\mathrm{~kg} \mathrm{ha}^{-1}$ & $<.001$ & $2862 a b$ & $3504 \mathrm{c}$ & 3349 c & $2892 a b$ & $2830 a b$ & $3029 \mathrm{~b}$ & 2761 a & 210 \\
\hline DM yield H3 & $\mathrm{kg} \mathrm{ha}^{-1}$ & $<.001$ & $3652 b$ & $3156 \mathrm{a}$ & 3217 a & $3885 \mathrm{~b}$ & $3711 \mathrm{~b}$ & $3741 \mathrm{~b}$ & $3836 \mathrm{~b}$ & 345 \\
\hline $\mathrm{DM}$ yield $\mathrm{H} 4$ & $\mathrm{~kg} \mathrm{ha}^{-1}$ & $<.001$ & 1477 a & 1439 a & $1450 \mathrm{a}$ & $1655 \mathrm{~b}$ & $1755 \mathrm{~b}$ & $1750 \mathrm{~b}$ & $1716 \mathrm{~b}$ & 145 \\
\hline $\mathrm{N}$ yield (year) & kg.ha $a^{-1} y^{-1}$ & $<.001$ & $302 a$ & $349 \mathrm{~b}$ & $362 b$ & $320 \mathrm{a}$ & $301 \mathrm{a}$ & $310 \mathrm{a}$ & $306 a$ & 29 \\
\hline $\mathrm{N}$ yield $\mathrm{H} 1$ & $\mathrm{~kg} \mathrm{ha}^{-1}$ & $<.001$ & $88 a$ & $119 \mathrm{~b}$ & $137 \mathrm{~b}$ & 96 a & $84 a$ & $88 \mathrm{a}$ & $89 a$ & 21 \\
\hline $\mathrm{N}$ yield $\mathrm{H} 2$ & $\mathrm{~kg} \mathrm{ha}^{-1}$ & $<.001$ & 69 a & $94 \mathrm{~b}$ & $89 \mathrm{~b}$ & $67 \mathrm{a}$ & 65 a & $67 \mathrm{a}$ & $62 \mathrm{a}$ & 8.8 \\
\hline $\mathrm{N}$ yield $\mathrm{H} 3$ & $\mathrm{~kg} \mathrm{ha}^{-1}$ & 0.057 & 102 & 92 & 92 & 110 & 101 & 106 & 104 & 13 \\
\hline $\mathrm{N}$ yield $\mathrm{H} 4$ & $\mathrm{~kg} \mathrm{ha}^{-1}$ & 0.001 & $43 \mathrm{a}$ & $44 a b$ & $43 \mathrm{a}$ & $47 \mathrm{abc}$ & $51 \mathrm{c}$ & $48 \mathrm{bc}$ & $50 \mathrm{c}$ & 4.4 \\
\hline DM \% (year) & g $100 \mathrm{~g}^{-1}$ & 0.025 & $18 \mathrm{~b}$ & $17 \mathrm{a}$ & $17 \mathrm{a}$ & $17 \mathrm{a}$ & $17 \mathrm{a}$ & $17 \mathrm{a}$ & $17 \mathrm{a}$ & 0.6 \\
\hline $\mathrm{DM} \% \mathrm{H} 1$ & g $100 \mathrm{~g}^{-1}$ & 0.001 & $18 \mathrm{c}$ & $16 a b$ & $15 \mathrm{a}$ & $17 \mathrm{bc}$ & $18 \mathrm{c}$ & $17 \mathrm{bc}$ & $17 \mathrm{bc}$ & 1.2 \\
\hline $\mathrm{DM} \% \mathrm{H} 2$ & g $100 \mathrm{~g}^{-1}$ & 0.003 & $21 \mathrm{c}$ & $20 a b$ & $19 \mathrm{a}$ & $20 a b$ & $20 \mathrm{~b}$ & $20 \mathrm{~b}$ & $20 \mathrm{bc}$ & 0.9 \\
\hline $\mathrm{DM} \% \mathrm{H} 3$ & g $100 \mathrm{~g}^{-1}$ & 0.001 & $17 \mathrm{bc}$ & $17 \mathrm{bc}$ & $17 \mathrm{c}$ & $16 a b$ & $16 \mathrm{a}$ & $16 \mathrm{a}$ & $16 \mathrm{a}$ & 0.9 \\
\hline DM \% H4 & g $100 \mathrm{~g}^{-1}$ & $<.001$ & $18 \mathrm{bc}$ & $18 \mathrm{bc}$ & $18 \mathrm{c}$ & $17 a b$ & $16 \mathrm{a}$ & $17 \mathrm{a}$ & $17 a b$ & 0.8 \\
\hline $\mathrm{N}$ content (year) & g.kg DM ${ }^{-1}$ & $<.001$ & $27 \mathrm{~b}$ & $29 b c$ & $30 \mathrm{c}$ & $26 a$ & $25 \mathrm{a}$ & $25 a$ & $25 \mathrm{a}$ & 1.4 \\
\hline $\mathrm{N}$ content $\mathrm{H} 1$ & g.kg DM ${ }^{-1}$ & $<.001$ & $28 \mathrm{~b}$ & $29 \mathrm{~b}$ & $33 \mathrm{c}$ & $24 \mathrm{a}$ & $23 a$ & $22 \mathrm{a}$ & $24 \mathrm{a}$ & 3.2 \\
\hline $\mathrm{N}$ content $\mathrm{H} 2$ & g.kg DM ${ }^{-1}$ & $<.001$ & $24 \mathrm{a}$ & $27 \mathrm{~b}$ & $27 \mathrm{~b}$ & $23 a$ & $23 a$ & $22 a$ & $23 a$ & 2.0 \\
\hline $\mathrm{N}$ content $\mathrm{H} 3$ & g.kg DM ${ }^{-1}$ & 0.242 & 28 & 29 & 29 & 28 & 27 & 28 & 27 & 1.9 \\
\hline $\mathrm{N}$ content $\mathrm{H} 4$ & g.kg DM ${ }^{-1}$ & 0.030 & $29 a b c$ & $31 \mathrm{c}$ & $30 \mathrm{bc}$ & $29 a b$ & $29 a b c$ & $28 a$ & $29 \mathrm{bc}$ & 1.6 \\
\hline Fresh yield H1 & $\mathrm{Mg} \mathrm{ha}^{-1}$ & $<.001$ & $17.3 \mathrm{a}$ & $25.0 \mathrm{~cd}$ & $26.7 \mathrm{~d}$ & $23.0 \mathrm{bc}$ & $20.3 a b$ & $22.8 b c$ & $21.4 \mathrm{~b}$ & 3.4 \\
\hline
\end{tabular}


Table S5.6 Botanical parameters of drained peat grassland after three years of fertilizer treatments, June 2015. Treatment codes: see Table S5.1.

\begin{tabular}{|c|c|c|c|c|c|c|c|c|c|c|}
\hline Parameter & Unit & $P$-value & Contr & IF & $\mathrm{IF}+\mathrm{SD}$ & Slurry & Comp & FYM & SFrac & I.s.d. \\
\hline Productive grasses & $\%$ & 0.193 & 89 & 87 & 85 & 88 & 87 & 88 & 87 & 2.6 \\
\hline Monocotyledons & $\%$ & 0.293 & 95 & 94 & 92 & 93 & 93 & 94 & 92 & 2.5 \\
\hline Dicotyledons & $\%$ & 0.312 & 6 & 6 & 9 & 8 & 8 & 7 & 8 & 3 \\
\hline Plant species & $n$ & 0.581 & 14 & 14 & 14 & 15 & 13 & 15 & 15 & 1.8 \\
\hline - Monocotyledon & $\mathrm{n}$ & 0.666 & 6.5 & 6.5 & 6.8 & 6.3 & 6.2 & 6.2 & 6.5 & 0.8 \\
\hline - Dicotyledon & $\mathrm{n}$ & 0.416 & 7.2 & 7.5 & 7.0 & 8.2 & 6.8 & 8.3 & 8.0 & 1.7 \\
\hline
\end{tabular}

Table S5.7 Fertilizer application dates and rates in the sampling year 2015: (Mg product ha ${ }^{-1}$; $\%$ of year total in brackets). Treatment codes: see Table S5.1. CAN: calcium ammonium nitrate.

\begin{tabular}{llrrrr}
\hline Treatment & Fertilizer & Date 1 & Rate (date 1) & Date 2 & Rate (date 2) \\
\hline IF & CAN & $1-4$ & $0.30(67 \%)$ & $20-5$ & $0.15(33 \%)$ \\
IF+SD & Sawdust & $20-2$ & $2.85(67 \%)$ & $20-5$ & $1.43(33 \%)$ \\
& CAN & $1-4$ & $0.30(67 \%)$ & $20-5$ & $0.15(33 \%)$ \\
Slurry & Slurry & $20-3$ & $24.0(60 \%)$ & $20-5$ & $16.0(40 \%)$ \\
Comp & Compost & $20-2$ & $8.00(73 \%)$ & $20-5$ & $3.00(27 \%)$ \\
FYM & Farmyard manure & $23-2$ & $12.50(53 \%)$ & $20-5$ & $11.25(47 \%)$ \\
SFrac & Solid fraction & $20-2$ & $15.25(64 \%)$ & $20-5$ & $8.50(36 \%)$ \\
\hline
\end{tabular}




\section{Chapter 6}

\section{General discussion}

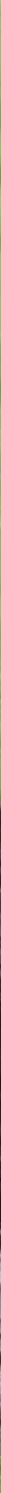

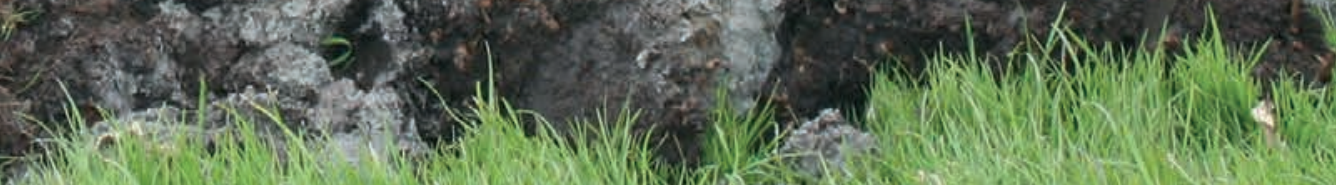





\subsection{Introduction}

There is an increasing pressure from governments globally to reduce the $\mathrm{CO}_{2}$ emission of drained peat areas. For peat grasslands in the Netherlands, society also requires that key biodiversity is supported, that soils can buffer rainwater, and that dairy farms produce without negative impact on the environment. This mix of demands calls for an integral approach that focuses on soil quality, as the functioning of the soil is the basis for most ecosystem services. The objective of this thesis was therefore to get insight in the soil quality of peat grasslands in relation to the ecosystem services they deliver to society, and to evaluate the effects of land management measures from this integral perspective.

In the previous four chapters, the results of explorative measurements and factorial experiments were presented and discussed. In this chapter, I discuss and synthesize the main findings from an ecosystem service perspective: what novel insights do they provide for the support of biodiversity and for climate regulation, water regulation and grass production in peat grasslands, and what are the next research steps needed (section 6.2)? I also explore possibilities for implementation of the results in the management of dairy and semi-natural grasslands and end with perspectives for regenerative agriculture on peat (section 6.3).

\subsection{Novel insights in ecosystem services of peat grasslands}

\subsubsection{Support of biodiversity}

In this thesis, I evaluated the soil's ecosystem service of supporting biodiversity at grassland and land use scale in Chapters 2 (dairy versus semi-natural grasslands) and 5 (effects of fertilizers) with emphasis on abundance, functional diversity and taxonomic richness of soil organisms. The taxonomic richness in soil has an intrinsic value with an indirect and longer term benefit for society, but may also be seen as an indicator of the general life-support function of soils. The abundance and diversity of soil biota affect the below- and aboveground food web and are essential for organisms at higher trophic levels, such as meadow birds, that are more commonly seen as part of a cultural or natural ecosystem value that should be protected, than the soil biota itself. In this section, I discuss both 
aspects: first the spatial scale effects on soil biodiversity, then the effects of land use and management on the food availability for meadow birds.

\subsubsection{Scale effects on soil biodiversity}

In Chapter 2, a combined effect of land use and spatial scale on taxonomic richness of the flora and soil fauna was presented. In the twenty dairy grasslands studied, the average number of taxa - for those groups together - was higher compared to the twenty seminatural grasslands, as was their abundance. This was especially caused by larger numbers of nematode and enchytraeid species. However, the total number of taxa found in all dairy grasslands together was $21 \%$ lower than in the semi-natural grasslands. The relation between soil biodiversity and spatial scale has been examined by a number of authors and is explained with various ecological mechanisms (Bardgett, 2005; Ekschmitt and Griffiths, 1998; Ettema and Wardle, 2002; Thakur et al., 2020; Wardle, 2006, 2002). In soil, both the resource availability (energy and nutrients) and habitat heterogeneity (spatial structure, resource partitioning) appear to be basal positive drivers of the abundance and taxonomic richness of biota. Additionally, biotic interactions at different scales below- and aboveground influence soil biota community structures.

At grassland scale, the higher nematode abundance in the dairy grasslands was mainly due to increased numbers at higher trophic levels (bacterivores, predators and omnivores) and not at the lowest level of primary consumers (herbivores) (Chapter 2, Table S2.2). This more developed nematode community indicates a richer soil environment, which was also shown by the higher enrichment index (Ferris et al., 2001). The same was indicated by the higher occurrence of Fridericia enchytraeids in the dairy grasslands, which are classified as K-strategists (Jänsch et al., 2005). Moreover, the total number of soil faunal species correlated positively with $\mathrm{pH}$ and grass root density (Fig. 2.2a), indicating a larger nutrient and energy availability. Thus, at grassland scale, the richer soil conditions in the dairy grasslands - that were well-drained, fertilized and had a high primary production supported a more complex soil ecosystem containing a higher abundance and taxonomic richness of soil organisms.

At landscape scale, however, the higher species diversity may be explained by a higher heterogeneity across semi-natural grasslands compared to dairy grasslands: the range in soil chemical and physical conditions was larger for those grasslands as a result of large 
differences in drainage and grassland management between sites (Table 2.1). Not only the total number of species was larger in semi-natural grassland, but $33 \%$ of the species were specific for this land use type, against 15\% for dairy grasslands (Fig. 2.1: compare 'only in N' with ' $N$ ', and 'only in $D$ ' with ' $D$ '). Together with the lower species number per grassland, this shows that the higher occurrence of species in the semi-natural grasslands together was due to the addition of spatially separated and different species communities.

I therefore conclude that the relationship between biodiversity and spatial scale in peat grasslands depends on the land use due to differences in both resource availability and spatial heterogeneity. This relationship is summarized in Fig. 6.1: the scale-related increase of biodiversity is larger in semi-natural grasslands than in dairy grasslands, and the combination of land uses has an additional biodiversity value. In future research, effects of land use and management on biodiversity at different spatial scales should be further examined, including the additional value of nature and dairy grasslands for example in 'nature inclusive' farming.

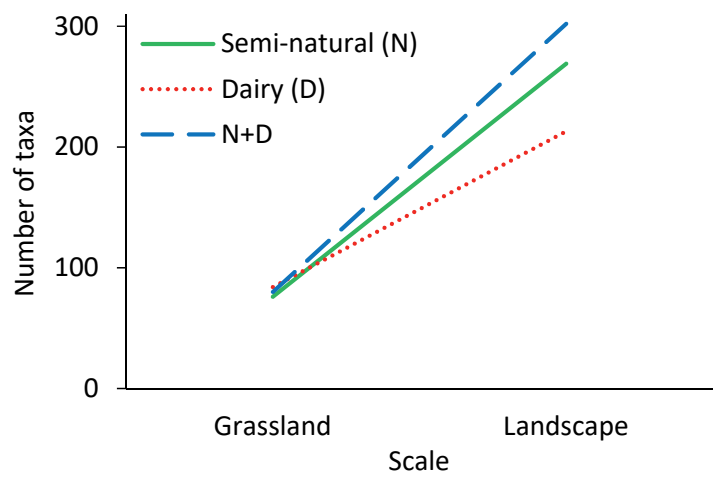

Figure 6.1 Number of soil and plant taxa as a function of scale for semi-natural and dairy grasslands on peat soils and their combination (data from Chapter 2).

\subsubsection{Grassland management and food availability for meadow birds}

Most meadow birds of Dutch grasslands are migratory and breed in the Netherlands. The declining number of meadow birds over the last decades is partly due to intensification of farming which reduces their habitat quality and food availability (Beintema, 1986; Kentie et al., 2015; Kruk et al., 1996; Onrust, 2017). Adult meadow birds feed mainly on earthworms living in the topsoil and on the soil surface (Onrust et al., 2017), and chicks of most species 
feed on insects found in the vegetation (Beintema et al., 1991). This thesis provides information on land use (Chapter 2) and fertilizer (Chapter 5) effects on the abundance of earthworms in peat grasslands, and on factors related to the accessibility of earthworms for meadow birds - soil moisture and soil penetration resistance (Onrust et al., 2019; Vickery et al., 2001) - and related to the presence of insects and their accessibility to meadow bird chicks - botanical composition and grass growth parameters (Atkinson et al., 2005; Vickery et al., 2001). With their surfacing behaviour, epigeic and anecic earthworms (Bouché, 1977) are most accessible to visually hunting meadow birds such as the lapwing (Vanellus vanellus) (Butt et al., 2003; Onrust et al., 2019). For tactile hunting birds such as the black-tailed godwit (Limosa limosa), also endogeic worms (Bouché, 1977) are potential preys (Onrust, 2017). In the absence of anecic species in the western peat grasslands in the Netherlands (Chapter 2), this section focuses on epigeic and endogeic earthworms.

Earthworms were responsive to both land use (Chapter 2) and fertilization strategy (Chapter 5): semi-natural grasslands contained on average only $51 \%$ and $43 \%$ of the numbers of epigeic and endogeic earthworms, respectively, found in dairy grasslands (Table S2.2). In addition, a larger proportion of juveniles was measured in dairy grasslands, indicating suitable soil conditions for reproduction. Moreover, the abundance of epigeic earthworms was promoted by fertilizers that combined (organic) $\mathrm{N}$ with large amounts of non-humified organic matter, especially the solid fraction of mechanically separated slurry manure. These findings are in line with the general positive relation between resource availability and soil biota discussed in the previous section. In both studies, earthworm sampling was carried out in April, which coincides with the presence of meadow birds in the Netherlands. Therefore, for grasslands with a meadow bird conservation goal, the results stress the importance of soil quality management that sufficiently supports the populations of earthworms and other invertebrates that are food for meadow birds. The results of this thesis provide elements linking land use, management, soil quality and food availability for meadow birds that are discussed below.

\section{Soil acidity}

A positive relationship between soil $\mathrm{pH}_{\mathrm{KCl}}$ (3.5-5.5) and the abundance of earthworms was found across the 40 grasslands on peat, with a lower mean $\mathrm{pH}$ and earthworm abundance in semi-natural grasslands (Fig. 6.2). The correlations of $\mathrm{pH}_{\mathrm{KCl}}$ with the numbers of epigeic and endogeic separately were similar to that with the total abundance $(r=+0.60$ and $r=$ 
+0.61 respectively, with $P<0.001$; data from Chapter 2). Other studies in different soil types have reported similar findings, also regarding the absence of earthworms at $\mathrm{pH}_{\mathrm{KCl}}$ below 3.5 (Curry, 2004; Klok et al., 2007; Ma et al., 1990). In a study in Scotland, soil pH explained part of the variability in lapwing distribution (McCallum et al., 2015). Therefore, I conclude that in grasslands on peat with a meadow bird protection goal, soil acidification should be routinely monitored.

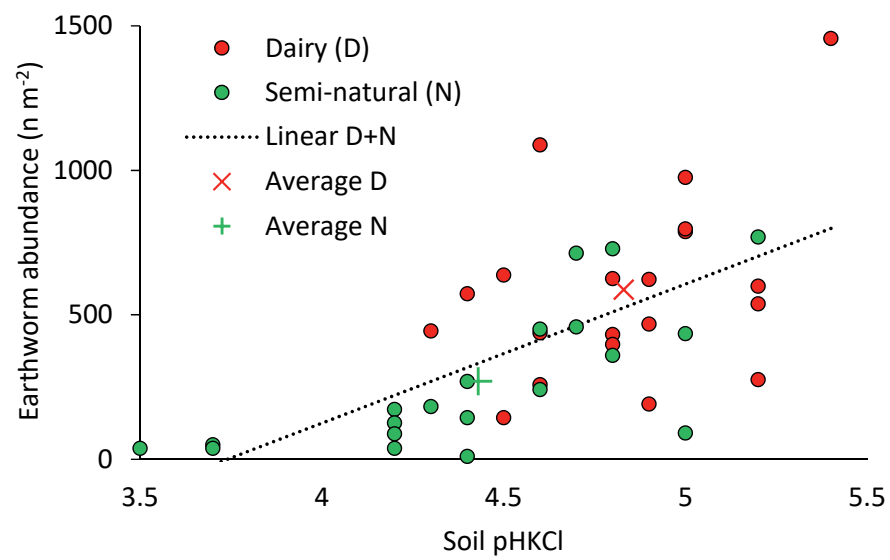

Figure 6.2 Abundance of earthworms as a function of soil $\mathrm{pH}_{\mathrm{Kcl}}$ in dairy and semi-natural grasslands on peat $(r=+0.64, P<0.001$; data from Chapter 2$)$.

\section{Solid manures}

A new insight provided by the experiment described in Chapter 5 is that the solid fraction of slurry manure can be used in meadow bird grasslands as an alternative to farmyard manure. Solid fraction resulted in a higher abundance of epigeic earthworms, without detrimental effects on other soil quality parameters and grass yield. The availability of $P$ in soil (here indicated by $\mathrm{P}_{\mathrm{AL}}$ ) was increased by compost and farmyard manure, but not with solid fraction. This finding may be essential in areas where the availability of farmyard manure is low or where the use of solid manure should not increase soil P concentration.

Apparently, the addition of large amounts of relatively fresh organic matter stimulates soil biota even in peat soil that is already rich in organic matter. This shows that the peat itself has a low nutritional value for soil organisms, and supports the proposition of Leroy et al. (2008) that earthworms profit more from non-humified organic matter than from composted and stabilized material. Moreover, the results of Chapter 5 indicate that not only $\mathrm{C}$ but the 
combination with $\mathrm{N}$ is favourable to earthworms. In our experiment, the applied quantity of solid fraction was equivalent to $6.2 \mathrm{Mg}$ organic matter ha ${ }^{-1} \mathrm{yr}^{-1}$ (C:N ratio of 23; $120 \mathrm{~kg}$ total $\mathrm{N}$ ). With farmyard manure, $4.2 \mathrm{Mg}$ organic matter was added at the same $\mathrm{N}$ rate (C:N ratio of 14). The slurry separation techniques used in agriculture result in solid fractions with a broad range of nutrient and organic matter contents (Hjorth et al., 2010). A similar variation is found in farmyard manures for which both the added organic material and the composting process during storage can greatly differ (Levi-Minzi et al., 1986). Further research should therefore study the effects of a broader range of solid fraction and farmyard manures on soil biota and nutrient concentrations to better represent their variability in practice. Moreover, the availability of solid fraction per unit of area should be quantified in relation to grass yield and manure production. Lastly, the use of liquid fraction in dairy grasslands, possibly combined with the application of solid fraction at different moments and locations, should be evaluated.

I conclude that grasslands managed for the protection of meadow birds can benefit from the addition of non-humified organic manures, even on peat soils. Solid fraction of slurry is a potential alternative to farmyard manure.

\section{$\underline{\text { Soil moisture and penetration resistance }}$}

Soil moisture appears to be a key factor in determining the accessibility of earthworms to meadow birds due to the combined effect on earthworm activity (Edwards and Bohlen, 1996; Onrust et al., 2019) and penetration resistance (Elbanna and Witney, 1987). Boundary values have been reported for soil moisture of 30\% (minimum) (Edwards and Bohlen, 1996; Onrust et al., 2019) and for penetration resistance of the topsoil of $125 \mathrm{~N} \mathrm{~cm}^{-2}$ (maximum) (StruweJuhl, 1995). In the peat soils (Chapters 2 and 5), I measured much higher soil moisture contents (42 to 77\%) in April, and generally very low penetration resistance (50 to $130 \mathrm{~N} \mathrm{~cm}^{-2} ; 1$ dairy and 2 semi-natural grasslands above $125 \mathrm{~N} \mathrm{~cm}^{-2}$ ). For meadow birds, earthworms are staple food especially in February to April (pre-breeding period) (Galbraith, 1989; Högstedt, 1974). During this period in which earthworm accessibility is crucial, the soil moisture generally decreases and the penetration resistance increases with rising temperatures and evapotranspiration. My data from the second half of April therefore apply to the least favourable situation. In conclusion, I suggest that in peat grasslands in general, the accessibility of earthworms during the crucial moment for meadow birds in spring is not impaired by the soil moisture content or penetration resistance. 


\section{Botanical composition and sward density}

The percentage of dicotyledons was significantly higher in semi-natural grasslands compared to dairy grasslands, which could indicate a better habitat for insects, and hence, for meadow bird chicks (Beintema et al., 1991). However, in the fertilizer experiment, the percentage of grasses was still above $90 \%$ after three years in all treatments including the control, although the fertilizer $\mathrm{N}$ input had been reduced from $280 \mathrm{~kg} \mathrm{ha}^{-1} \mathrm{yr}^{-1}$ before the experiment to 120 and $0 \mathrm{~kg} \mathrm{ha}^{-1} \mathrm{yr}^{-1}$ during the experiment, depending on treatment.

The sward density is another indicator of the habitat quality for meadow bird chicks. In an uniform dense or open sward, the accessibility of insects is reduced, leading to low foraging success (Schekkerman and Beintema, 2007). Moreover, the protection against predation is reduced, leading to low hiding success. In this thesis, the grass yield can be used as indicator for sward density and for the earliness of the first cut. The dry matter yield of the first harvest in twenty dairy grasslands (Chapter 3 ) ranged from 1.9 to $4.3 \mathrm{Mg} \mathrm{ha}^{-1}$ (unfertilized) and 3.5 to $5.8 \mathrm{Mg} \mathrm{ha}^{-1}$ (fertilized with inorganic $\mathrm{N}$ fertilizer). In the fertilizer experiment (on one location; Chapter 5), a lower dry matter yield was found in the first harvest for the control compared to the fertilizers, but the difference was smaller with fertilizers with low mineral $\mathrm{N}$ content (especially compost) compared to that with inorganic $\mathrm{N}$ fertilizers (Table S5.5).

As different meadow bird species have different food and habitat preferences, a mosaic structure at grassland, farm and landscape scale would support the habitat quality for meadow birds in general (Wiggers et al., 2015).

I conclude that in peat soils with high soil $\mathrm{N}$ supply, even a strong reduction of $\mathrm{N}$ application does not lead to a more diverse botanical composition in the mid-term (3 years) but that a low mineral $\mathrm{N}$ application can reduce the sward density and retard the grass harvest. In the longer term, I showed in Chapter 2 that conversion to semi-natural grassland (with reduced drainage, stocking and manuring intensity) increased the proportion of dicotyledons, which is positive for insect-feeding meadow bird chicks.

\subsubsection{Climate regulation and water regulation}

The activity of soil biota is directly related to the ecosystem services of climate regulation and water regulation. Soil microbes and microbial enzymes both stabilize (Kallenbach et al., 2016) and decompose (Fernández-Calviño and Bååth, 2010; Rousk et al., 2011) organic matter in soil, leading to $\mathrm{C}$ fixation or $\mathrm{CO}_{2}$ emission, both important for climate regulation. The 
burrowing and mixing activity of the larger soil organisms influence the physical properties of soil that determine water storage and water infiltration (Brussaard et al., 1997; Lavelle et al., 2006), important for water regulation. In this thesis, these two ecosystem services are treated from the perspective of the soil biota that are mostly located in the topsoil (to c. $20 \mathrm{~cm}$ depth) in an effort to provide insight in the processes underlying the actual $\mathrm{CO}_{2}$ emission or water storage capacity of grasslands, that, as ecosystem services, are relevant at larger spatial and temporal scales (Brouns et al., 2014; De Vos et al., 2010). In this section, I discuss the most important findings regarding climate regulation and water regulation.

\subsubsection{Climate regulation: organic matter dynamics in the topsoil}

Measurements in the topsoil of dairy and semi-natural grasslands provided insight in the linkages between potential $\mathrm{C}$ mineralization, total and labile $\mathrm{C}$ pools and (other) biotic and abiotic parameters (Chapters 2, 4 and 5). From Chapter 2, no indication was found that the dairy grasslands emit more $\mathrm{CO}_{2}$ from the topsoil than the semi-natural grasslands despite a higher $\mathrm{pH}$ and labile $\mathrm{C}$ content, a deeper drainage and a larger $\mathrm{C}$ input. I concluded that not only high water contents but also drought limits $C$ turnover in peat topsoil, and that soil biota are adapted to different sources of labile $\mathrm{C}$ in both types of grasslands, in this case hot water extractable C (HWC) in dairy and water soluble C (WSC) in semi-natural grasslands. Also in Chapter 4, the labile C (measured as HWC) appeared to be sensitive to the differences in soil conditions induced by the application of lime and other minerals, and was an indicator of organic matter stabilization and decomposition processes. The interpretation of changes in HWC concentrations for the total organic matter (SOM) dynamics was context-dependent. A reduction in HWC could indicate stabilized organic matter (by Ca binding (Rowley et al., 2018)) or, in contrast, increased decomposition (associated with higher pH (Ghani et al., 2003)). An increased HWC concentration could indicate higher input of labile $\mathrm{C}$ (by manure and plant residues), reduced decomposition (due to Ca binding) or increased dissolution of organic $\mathrm{C}$ (where pH was increased (Andersson and Nilsson, 2001; Oste et al., 2002)). Moreover, soil P availability was involved because of potential $P$ limitation of the decomposition process (Amador and Jones, 1993; Brouns et al., 2016). In the fertilizer experiment (Chapter 5), the microbial parameters indicated a shift towards more bacterial based processes in grasslands fertilized with inorganic $\mathrm{N}$ fertilizer, which was in line with the more bacterial driven $\mathrm{C}$ mineralization in the dairy grasslands compared to semi-natural grasslands (Chapter 2). No 
clear effects on SOM or HWC were observed in Chapter 5 possibly due to the relatively low fertilization rates.

From these findings, I conclude that due to the interaction of factors involved in the decomposition of organic matter in peat soils, effects of land use or grassland management on organic matter decomposition in these soils need to be evaluated with a comprehensive set of soil chemical and microbiological parameters. The work in this thesis indicates that for the topsoil in peat grasslands, reduced drainage, grazing and manuring intensities do not necessarily lead to a lower organic matter decomposition rate because the soil biota adapts to the soil conditions. Fertilizers influence soil biota depending on their quality and application quantity, but without clear net decomposition or accumulation effects on SOM. In contrast, the application of lime influences the decomposition and mineralization of SOM, potentially leading to large $\mathrm{C}$ and $\mathrm{N}$ losses.

The results of this thesis show that different (labile) fractions of SOM, their ratio and their interactions with soil microbes and soil chemical conditions provide information on the effects of land management on the ecosystem service of climate regulation. In further research, the $\mathrm{C}$ dynamics in the topsoil and in deeper soil layers should be studied more explicitly, including the temporal fluctuation within the growing season and the role of $C$ input by plant residues, to better quantify management effects at larger scales (grassland, farm, land use type).

\subsubsection{Water regulation: topsoil processes}

The water buffering capacity of peat grasslands was measured with water infiltration rate, soil water content, and more indirectly with soil structure and root density as indicators. In Chapter 2, I reported a wide range of soil physical properties across the forty peat grasslands. Dairy grasslands were generally drier, contained more crumb structures, macropores and roots than semi-natural grasslands. This resulted in faster water infiltration (Fig. 2.2c), which means that dairy grasslands better buffer rain water and that semi-natural grasslands are more prone to waterlogging. Structural equation modelling (Fig. 2.2c) provided a clear illustration of the statistical relationships between soil properties that result in the variation in water infiltration rate. Many of these relationships are described in literature as causal (Bouché and Al-Addan, 1997; Curry, 2004; Dettmann et al., 2014; Holden, 2005; Van Eekeren et al., 2009b), and the soil properties involved are inherently associated with the grassland management (drainage, biological activity) and vegetation characteristics (net primary 
production, root density). This illustrates the cyclic interactions between plant/roots, soil biota and soil properties (Van Eekeren et al., 2007). In the experiments in dairy grasslands with added minerals and fertilizers (Chapters 4 and 5), some effects on soil water content and penetration resistance were observed, but not or only marginally on soil structure, root density or water infiltration rate. I therefore conclude that the water infiltration capacity of peat grasslands is not easily influenced by usual management within a land use type.

An important factor influencing the water regulation and buffering capacity in peat areas is the strong water repellence (hydrophobicity) of dehydrated peat soils (Berglund and Persson, 1996; Dekker and Ritsema, 2000). This property is problematic in drained peat soils used for agriculture, as it prevents water absorption and rewetting of the soil during rainfall, which adds to the effects of prolonged drought. This can potentially affect grass yields and the decomposition of organic matter but also lead to increased runoff.

In Chapter 3, I suggested that water repellence was the main cause of the variation in grass dry matter yield across the twenty grasslands and that the soil C:SOM ratio was an indicator of water repellence. As these results were based on data from one year only, the importance of water repellence for agricultural practice, nutrient cycling and water regulation should be assessed over growing seasons.

\subsubsection{Grass production and N cycling}

In this thesis, both indirect and direct parameters were used as indicators of the provisioning ecosystem service of grass production. In Chapter 2, soil quality parameters were evaluated without grass yield measurements. In the subsequent three chapters, grass dry matter and $\mathrm{N}$ yields were measured along with soil quality parameters. These measurements not only provided information on the agricultural value of peat grasslands, but also on $\mathrm{N}$ cycling in terms of soil $\mathrm{N}$ supply (Chapters 3, 4), apparent $\mathrm{N}$ recovery (Chapters 3, 5), and the underlying processes of $\mathrm{N}$ mineralization (Chapters $2,3,4,5$ ). In this section, I integrate the main findings regarding these aspects.

\subsubsection{Unfertilized grass $N$ yield and $N$ mineralization}

For peat grasslands, earlier attempts to predict the unfertilized grass $\mathrm{N}$ yield - a proxy for the soil N supply (Vellinga and André, 1999) - from soil parameters were unsuccessful. Based on the results of the explorative studies described in Chapters 2 and 3,1 conclude that in the 
twenty dairy grasslands, the high availability of mineralized $\mathrm{N}$ was presumably not limiting grass growth: the soil $\mathrm{N}$ supply was not correlated with $\mathrm{N}$ mineralization but with Ca:Mg ratio and C:SOM ratio. Those parameters apparently indicated that the soil structure and water availability were more limiting growth (see discussion in Chapter 3). At the same time, I reported a positive yield effect of inorganic $\mathrm{N}$ fertilizer on grass yields in Chapter 3 . The combination of those findings (soil structure and water availability determine soil $\mathrm{N}$ supply and grass yield responds to inorganic $\mathrm{N}$ fertilizer) therefore indicates that unfertilized grass $\mathrm{N}$ yield is limited by soil mineral $\mathrm{N}$ but that the link is indirect via soil structure and water availability because they determine the rate of $\mathrm{N}$ mineralization by the soil biota. This is in line with a recent study reporting that models including temperature and SOM can estimate soil $\mathrm{N}$ supply (Pijlman et al., 2020), as both are also drivers of $\mathrm{N}$ mineralization.

The lack of a direct correlation between soil $\mathrm{N}$ supply and $\mathrm{N}$ mineralization in Chapter 3 may be caused by the complexity of calculating $\mathrm{N}$ mineralization from soil ecological data. Consequently, the selection of soil Ca:Mg ratio and C:SOM ratio as best predictors is interesting because they are stable and relatively simple soil parameters that apparently indicated how the twenty grasslands responded with the variable soil water availability during the growing season. The stability and simplicity of those parameters is an advantage for field application as approximate predictors for the variation in grass yield across sites, but they lack precision and sensitivity for temporal changes within the growing season.

The results of Chapter 4 showed that the effects of added minerals on grass $\mathrm{N}$ yield in a factorial experiment are not linked to the changes in $\mathrm{Ca}: \mathrm{Mg}$ ratio, but to effects on $\mathrm{pH}$ and $\mathrm{N}$ and $\mathrm{P}$ mineralization. Contrary to the hypothesis based on Chapter 3 , there were no clear $\mathrm{Ca}$ and $\mathrm{Mg}$ effects on soil structure or water availability. This was explained by the dominance of the anion $\left(\mathrm{CO}_{3}\right.$ and $\left.\mathrm{SO}_{4}\right)$ effects on soil acidity and mineralization in the two years after application, that could mask (possible) cation ( $\mathrm{Ca}$ and $\mathrm{Mg}$ ) effects on soil structure and water availability. Chapter 4 did therefore not provide evidence that the Ca:Mg ratio is causally linked with the unfertilized grass $\mathrm{N}$ yield, at least in the mid-term after manipulation of the Ca:Mg ratio.

I conclude that relatively simple soil parameters that are linked to factors that determine the complex process of $\mathrm{N}$ mineralization may be rough predictors of the spatial variation in unfertilized grass $\mathrm{N}$ yield on peat soil. 


\subsubsection{Fertilized grass yield and $N$ cycling}

The apparent $\mathrm{N}$ recovery of inorganic $\mathrm{N}$ fertilizer found in the twenty dairy grasslands was $65 \%$ (Chapter 3) and comparable to values found in grasslands before (Van Eekeren et al., 2010; Vellinga and André, 1999), but the range was wide (41 to 100\%). In the fertilizer experiment (Chapter 5) carried out in one peat grassland at a relatively low $\mathrm{N}$ application rate $(120 \mathrm{~kg}$ total $\mathrm{N} \mathrm{ha}^{-1} \mathrm{yr}^{-1}$ ), the apparent $\mathrm{N}$ recovery of inorganic $\mathrm{N}$ fertilizer was at the lower end of this range (39\%), and that of organic fertilizers was extremely low (-1 to 16\%). The organic fertilizers increased the grass dry matter yield but not the $\mathrm{N}$ yield compared to the unfertilized control, resulting in a lower grass $\mathrm{N}$ content. An explanation may be that organic fertilizers, that contain most of the $\mathrm{N}$ in organic form and also provide (labile) organic matter to the soil, increase the abundance and activity of the soil biota (Birkhofer et al., 2008; Van Eekeren et al., 2009a), resulting in stronger nutrient competition between plants and soil microorganisms (Månsson et al., 2009). The virtually absent recovery of the $\mathrm{N}$ added by the organic fertilizers would imply that $\mathrm{N}$ accumulated in soil, if not lost by denitrification or leaching. In both cases, it is important for dairy farming practice to better understand the $\mathrm{N}$ cycling in fertilized peat grasslands in order to prevent losses (Van Beek et al., 2004b).

There was a significant reduction in arbuscular mycorrhizal fungi in all fertilized treatments compared to the control, but the reduction was less pronounced where nonhumified organic matter was added (Chapter 5). This may indicate differences in nutrient acquisition and retention in the soil (De Vries et al., 2006) in favour of unfertilized grassland and grasslands with added C-rich material. However, the fate of the $\mathrm{N}$ added with organic fertilizers remains unclear and should be studied in more detail and in relation to the quality of the added organic matter.

I conclude that grass dry matter yields, but not grass $\mathrm{N}$ yields, are increased by organic fertilizers. Although indicative changes in microbial community were observed, the question remains whether the added $\mathrm{N}$ is immobilized and accumulated in soil or (subsequently) lost after denitrification or leaching.

\subsection{Implications for grassland management on peat soils}

The aim of this thesis was to evaluate effects of land use and management using the framework of supporting, regulating and provisioning ecosystem services. Based on this broad approach, general guidance for the sustainable land use and land management of peat 
grasslands can be formulated. In this section, I synthesize the recommendations that were provided in the previous chapters and I end with a perspective for regenerative agriculture on peat soil.

\subsubsection{Support of biodiversity in dairy and semi-natural grasslands}

Dairy grasslands on peat harbour a large and diverse community of soil organisms, but the differences between grasslands are small. This is apparently a result of a low inter-farm diversity in management, as generally found in intensive agriculture (Swift et al., 2004). The results in this thesis indicate that more diversity in management across grasslands and farms, possibly with further inclusion of nature in agriculture and vice versa, would benefit a higher biodiversity at the landscape scale. Therefore, the transition towards nature inclusive and regenerative agriculture (Erisman et al., 2016; Schreefel et al., 2020; Strootman et al., 2020) should be based on spatial diversification of grassland and soil management measures, that can start in stimulating diversity in farmers' initiatives and farming management. This can be achieved by advising farmers in their search, starting from local opportunities and taking their strengths and craftsmanship seriously.

Many dairy farmers on peatland are involved in protection schemes for meadow birds. In this thesis, solid fraction of slurry manure appeared to be a valuable alternative to farmyard manure. Possibly, other sources of fresh, non-humified organic matter are also appropriate. This knowledge can be used in meadow bird reserves for spatial diversification, in combination with other measures (e.g. botanical, hydrological or grazing measures).

The biodiversity value of semi-natural grasslands is clearly at a scale transcending the individual grassland. This is caused by the generally low nutrient input and primary production, and the large differences in management (drainage, stocking/mowing, manuring) between those grasslands. This insight may help manage nature areas coherently at the regional level, depending on the biodiversity goals aimed at. Moreover, cooperation with farmers in managing biodiversity can make the policy more effective. Specifically for meadow bird reserves, attention should be paid to the availability of soil invertebrates as influenced by the grassland management. 


\subsubsection{Regulation of organic matter dynamics and water quantity}

If the predictions of the effects of climate change (DeConto et al., 2021; Pörtner et al., 2019) come true, the combination of soil subsidence (due to peat decomposition) and sea level rise form a major threat for the continuity of dairy farming on peat in the coming century. Without providing a full solution to this global problem, my findings give insight in some soil processes concerning organic matter dynamics and hydrology in the topsoil that can contribute to mitigation of soil subsidence and $\mathrm{CO}_{2}$ emission and to adaptation to climate change.

Concerning soil organic matter dynamics, it appeared that topsoil C mineralization was not strongly influenced by land use (dairy or semi-natural grassland) due to adaptation of the microbial composition to the different soil conditions. This means that peat decomposition should be reduced in the deeper soil layers, for example with techniques to stabilize the groundwater at a higher level (e.g., by submerged drainage; (Ritzema and Stuyt, 2015)), and compensated, for example by input of organic matter-rich manure. For dairy grasslands, control of soil acidity by liming should be minimized as the losses by increased mineralization are much larger than the gains in grass yield. Possibly, an update of the current $\mathrm{pH}$ advice for peat grassland is needed. A promising measure to reduce the decomposition of SOM is the addition of clay to peat grasslands, which is currently under investigation at laboratory and field scale (Van Agtmaal et al., 2020), partly as a spin-off of the results of Chapter 2 (Table S2.4). For semi-natural grasslands, however, those measures are less obvious. Here, reduction of peat decomposition may necessitate a more radical re-wetting, which has a profound influence on the ecosystem service of support of biodiversity, and on surrounding (farmed) areas.

Concerning the regulation of water infiltration and water availability in the topsoil, the main recommendation from this thesis is to sustain a high soil biological activity (by organic matter input, drainage, control of soil acidity) and to prevent the soil to develop hydrophobicity (prevent desiccation). However, these measures conflict with the aim of reducing peat decomposition.

\subsubsection{Grass production and N cycling}

Due to the large stocks of organic $\mathrm{N}$ in peat grassland soils and the high $\mathrm{N}$ mineralization and soil $\mathrm{N}$ supply in comparison to mineral soils, dairy grasslands on drained peat are highly productive. However, the large $\mathrm{N}$ fluxes lead to substantial $\mathrm{N}$ surpluses and losses at field and 
farm level (Van Beek et al., 2004b). The main agronomic challenge is therefore to minimize those losses while maintaining grass production.

In peatlands, the grass $\mathrm{N}$ content often exceeds the 24 g.kg DM ${ }^{-1}$ (Hoekstra et al., 2019; Vellinga and André, 1999), which, in dairy herds, leads to high N excretion via urea and ultimately to ammonia emission (Bussink and Oenema, 1998; Edouard et al., 2019). From my results, I conclude that the use of inorganic $\mathrm{N}$ fertilizer should be avoided on drained peat soils as it further increases grass $\mathrm{N}$ contents. In contrast, organic fertilizers increase grass dry matter yield but reduce grass $\mathrm{N}$ content, which could reduce $\mathrm{N}$ losses. A drawback of organic fertilizers is their low apparent $\mathrm{N}$ recovery and the uncertainty about the fate of the added $\mathrm{N}$. Fertilizers with high contents of non-humified organic matter (here: solid fraction of slurry manure and sawdust) have a positive effect on the mycorrhizal fungi compared to other fertilizers, which may indicate a better retention of $\mathrm{N}$ in the plant-soil system (De Vries et al., 2006).

Farmers and society would benefit from a simple model to predict the soil $\mathrm{N}$ supply of peat grassland soils, as it can help to better match $\mathrm{N}$ fertilization with grass $\mathrm{N}$ uptake. In areas where the groundwater level of peat grasslands is increased to reduce greenhouse gas emission, an update of the (currently fixed) $\mathrm{N}$ fertilization advice for peat grasslands is even more important for farmers because the soil $\mathrm{N}$ supply is presumably lower. Next, the timing of the $\mathrm{N}$ supply within the growing season merits also attention. The different effects of fertilizers on grass $\mathrm{N}$ content and yield per harvest presented in Chapter 5 show that within the growing season, there is room to adjust the fertilization strategy (quality, quantity and timing) to the soil $\mathrm{N}$ supply, if the latter is predicted. The search for a prediction model for $\mathrm{N}$ mineralization in drained peat grassland should therefore be continued and include the $\mathrm{N}$ dynamics within the growing season.

\subsubsection{Perspective for regenerative agriculture on peatland}

What can farmers, nature conservation organizations and policymakers do, based on the results presented in this thesis, to develop regenerative agriculture on peat soil with a balanced delivery of ecosystem services?

Starting from current dairy farming practices, transition towards regenerative agriculture first and foremost requires a legislative and economic environment that supports diversity in farming systems and in farm management (between-farm diversity). This diversity is a driver 
for landscape-scale biodiversity. Moreover, diversity in farmers' initiatives can be a breeding ground for innovation in the management of regulating and provisioning ecosystem services as well.

Within such environment, individual farmers may aim for more within-farm diversity, for example by spatial and temporal differentiation in grassland management, and including a strategic use of solid and liquid (fractions of) manure depending on biodiversity, climate or production goals. Novel stable systems that combine animal welfare with manure separation at the source and reduced $\mathrm{N}$ emission (Deru et al., 2018b) can contribute to such differentiation. Cooperation with nature conservation organizations can increase the effectiveness of policy for landscape-scale biodiversity. Regarding climate change mitigation, the management of soil chemical properties to reduce SOM decomposition, including lowering $\mathrm{pH}$ and $\mathrm{P}$ availability, should be well-considered as it also influences the biodiversity, water regulation and grass production services. Similarly, measures to raise the groundwater level or to reduce SOM decomposition by organo-mineral complexation with clay may be implemented in future farming on peat, but deserve further research from an integral ecosystem service perspective.

I conclude that dairy farming on peatland is increasingly facing challenges that originate from societal needs. At the same time, soil quality is the basis for the most vital ecosystem services of peat grasslands. Farmers are well-equipped to manage soil quality and regenerate ecosystem services. This management is inextricably related to influencing the dynamics of soil organic matter and soil hydrology, and to coping with trade-offs between ecosystem services. Future implementation will therefore necessitate a fertile cooperation between the agricultural sector, nature conservation organizations and society at large. 


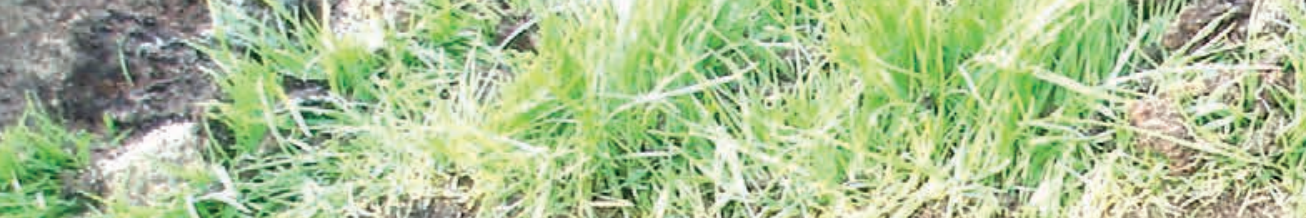
bers on

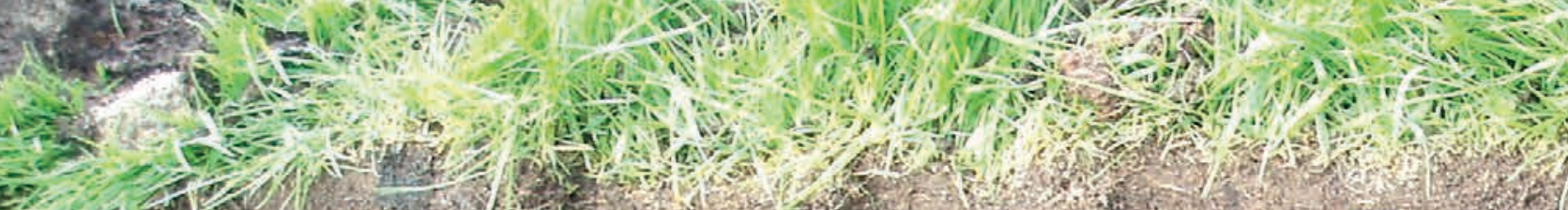
1.

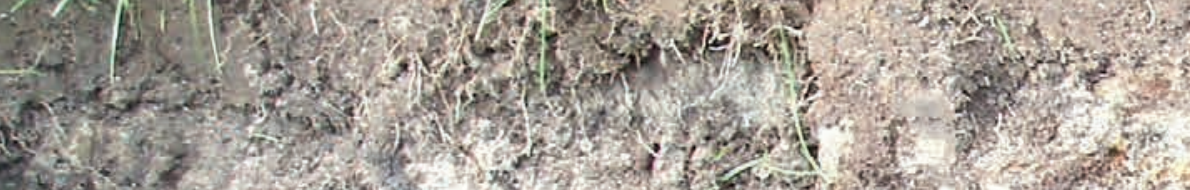

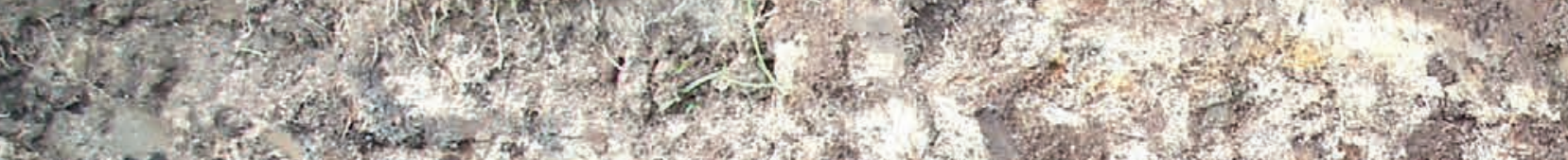

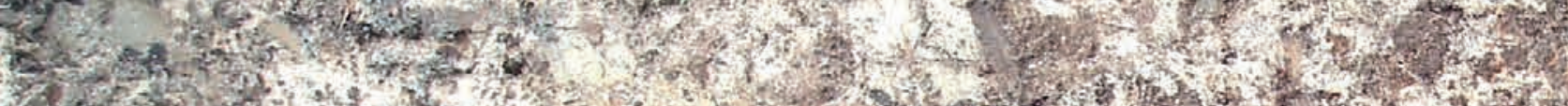

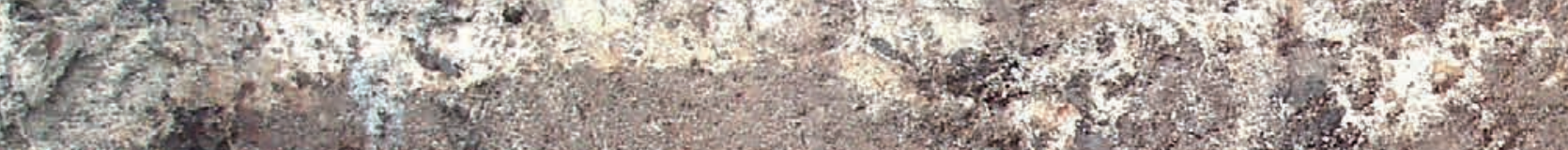
(1) (1)
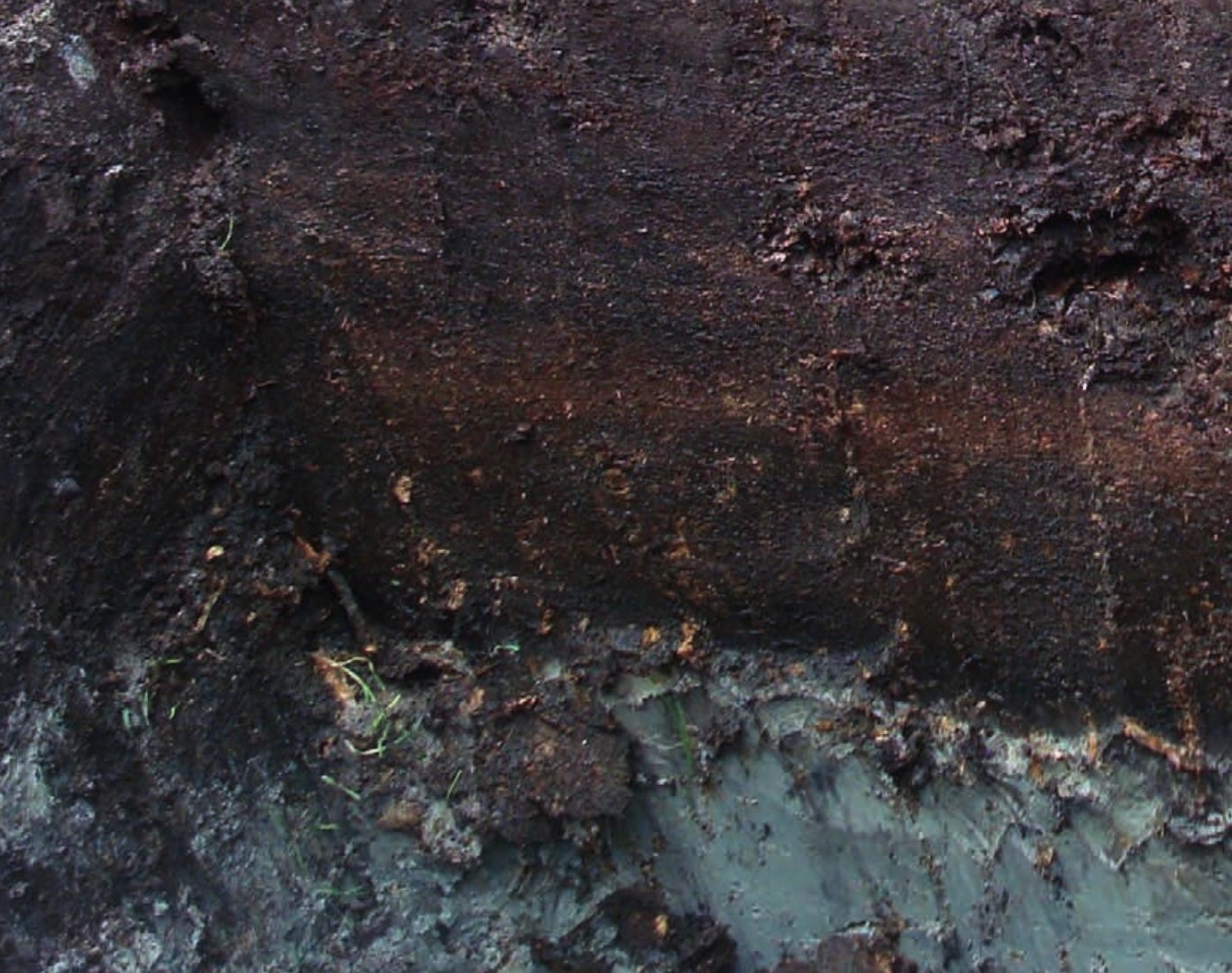


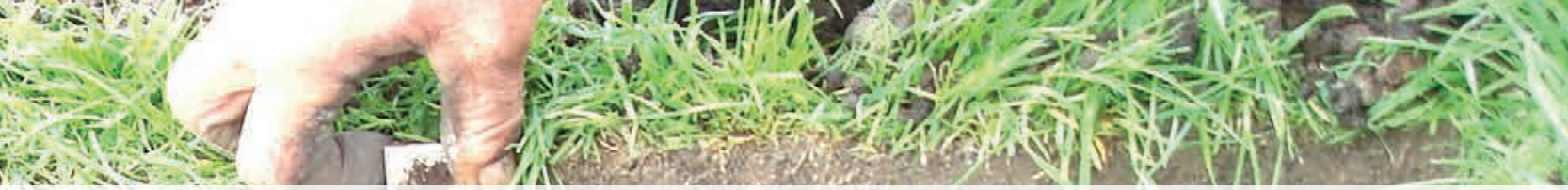

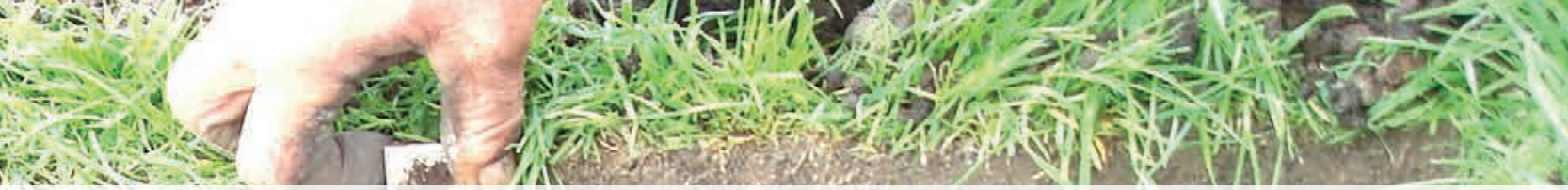

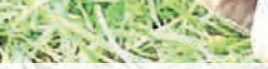

\section{References}

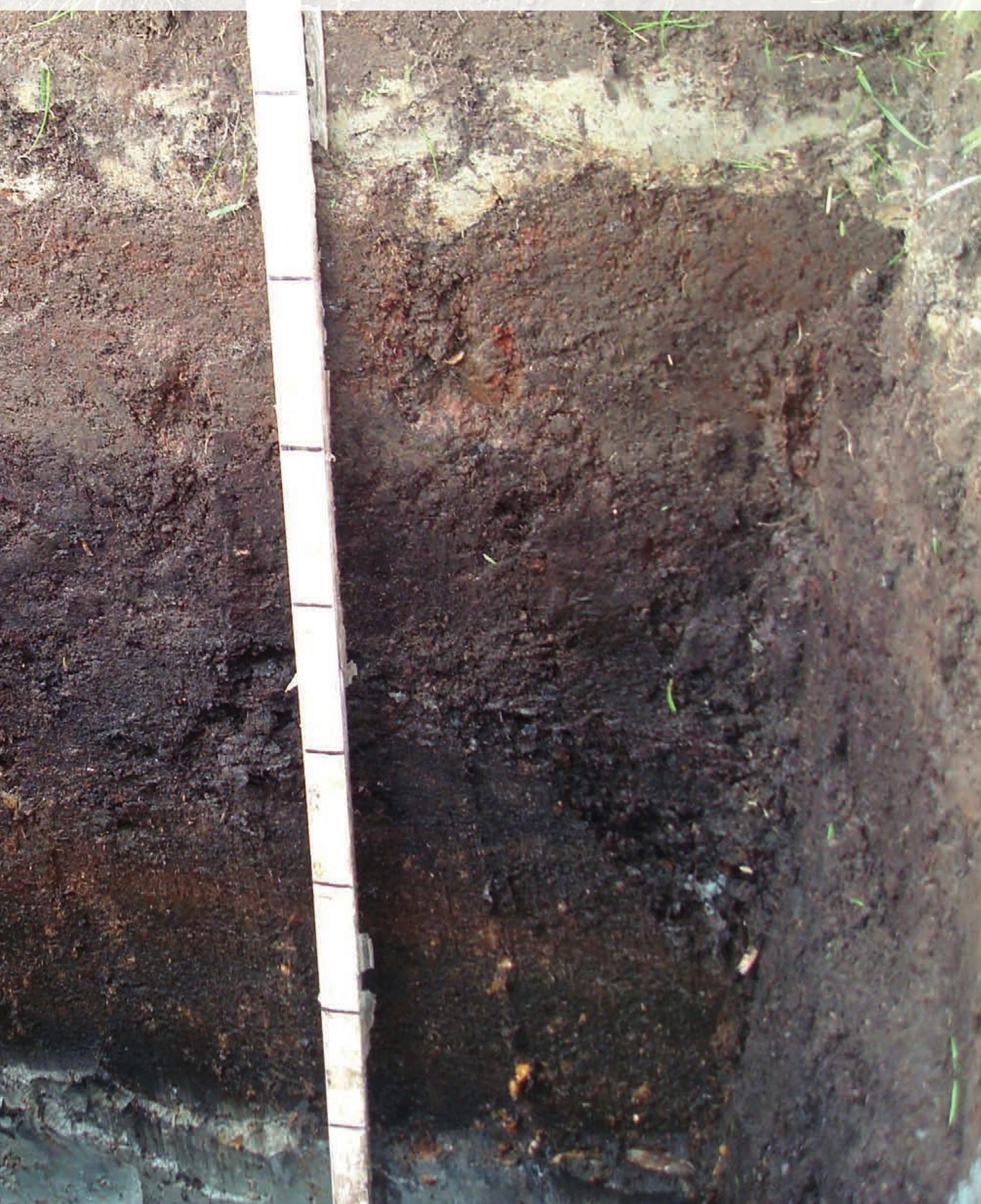





\section{References}

Aarts, H.F.M., de Haan, M.H.A., Schroder, J.J., Holster, H.C., de Boer, J.A., Reijs, J., Oenema, J., Hilhorst, G.J., Sebek, L.B., Verhoeven, F.P.M., Meerkerk, B., 2015. Quantifying the environmental performance of individual dairy farms-the Annual Nutrient Cycling Assessment (ANCA), in: van den Pol, A., Aarts, H.F.M., De Vliegher, A., Elgersma, A., Reheul, D.D., Reijneveld, J.A., Verloop, J., Hopkins, A. (Eds.), Grassland Science in Europe - Grassland and Forages in High Output Dairy Farming Systems. European Grassland Federation, Wageningen, pp. 377-380.

Adhikari, K., Hartemink, A.E., 2016. Linking soils to ecosystem services - A global review. Geoderma 262, 101111. https://doi.org/10.1016/j.geoderma.2015.08.009

Ahmad, W., Dijkstra, F.A., Dalal, R.C., Singh, B., 2020. Plant roots are more important than temperature in modulating carbon release in a limed acidic soil. European Journal of Soil Science 71, 727-739. https://doi.org/10.1111/ejss.12899

Albrecht, W.A., 1975. The Albrecht papers. Acres USA, Kansas City.

Amador, J.A., Jones, R.D., 1993. Nutrient limitations on microbial respiration in peat soils with different total phosphorus content. Soil Biology and Biochemistry 25, 793-801. https://doi.org/10.1016/00380717(93)90125-U

Andersson, B., Decker, R., Nierop, A.F.M., Bosaeus, I., Albertsson-Wikland, K., Hellgren, G., 2011. Protein profiling identified dissociations between growth hormone-mediated longitudinal growth and bone mineralization in short prepubertal children. Journal of Proteomics 74, 89-100. https://doi.org/10.1016/j.jprot.2010.08.007

Andersson, S., Nilsson, S.I., 2001. Influence of pH and temperature on microbial activity, substrate availability of soil-solution bacteria and leaching of dissolved organic carbon in a mor humus. Soil Biology and Biochemistry 33, 1181-1191. https://doi.org/10.1016/S0038-0717(01)00022-0

Armentano, T.V., 1980. Drainage of organic soils as a factor in the world carbon cycle. BioScience 30, 825-830. https://doi.org/10.2307/1308375

Atkinson, P.W., Fuller, R.J., Vickery, J.A., Conway, G.J., Tallowin, J.R.B., Smith, R.E.N., Haysom, K.A., Ings, T.C., Asteraki, E.J., Brown, V.K., 2005. Influence of agricultural management, sward structure and food resources on grassland field use by birds in lowland England: Factors influencing field use by grassland birds. Journal of Applied Ecology 42, 932-942. https://doi.org/10.1111/j.1365-2664.2005.01070.x

Ausec, L., Kraigher, B., Mandic-Mulec, I., 2009. Differences in the activity and bacterial community structure of drained grassland and forest peat soils. Soil Biology and Biochemistry 41, 1874-1881. https://doi.org/10.1016/j.soilbio.2009.06.010

Bardgett, R.D., 2005. The Biology of Soil: A Community and Ecosystem Approach. Oxford University Press, Oxford.

Bardgett, R.D., Cook, R., 1998. Functional aspects of soil animal diversity in agricultural grasslands. Applied Soil Ecology 10, 263-276. https://doi.org/10.1016/S0929-1393(98)00125-5

Bardgett, R.D., McAlister, E., 1999. The measurement of soil fungal:bacterial biomass ratios as an indicator of ecosystem self-regulation in temperate meadow grasslands. Biology and Fertility of Soils 29, 282-290. https://doi.org/10.1007/s003740050554

Bear, F.E., Toth, S.J., 1948. Influence of calcium on availability of other soil cations. Soil Science 65, 69-74.

Beintema, A.J., 1986. Man-made polders in the Netherlands: A traditional habitat for shorebirds. Colonial Waterbirds 9, 196-202. https://doi.org/10.2307/1521213

Beintema, A.J., Thissen, J.B., Tensen, B., Visser, G.H., 1991. Feeding ecology of Charadriiform chicks in agricultural grassland. Ardea 79, 31-44.

Beltman, B., Rouwenhorst, T.G., van Kerkhoven, M.B., van Der Krift, T., Verhoeven, J.T.A., 2000. Internal eutrophication in peat soils through competition between chloride and sulphate with phosphate for binding sites. Biogeochemistry 50, 183-194. https://doi.org/10.1023/A:1006374018558

Benjamini, Y., Hochberg, Y., 1995. Controlling the false discovery rate: A practical and powerful approach to multiple testing. Journal of the Royal Statistical Society. Series B (Methodological) 57, 289-300.

Berendse, F., Oomes, M.J.M., Altena, H.J., Elberse, W.Th., 1992. Experiments on the restoration of species-rich meadows in the Netherlands. Biological Conservation 62, 59-65. https://doi.org/10.1016/00063207(92)91152-I 
Berglund, K., Persson, L., 1996. Water repellence of cultivated organic soils. Acta Agriculturae Scandinavica, Section B - Soil \& Plant Science 46, 145-152. https://doi.org/10.1080/09064719609413127

Berglund, Ö., Berglund, K., 2011. Influence of water table level and soil properties on emissions of greenhouse gases from cultivated peat soil. Soil Biology and Biochemistry 43, 923-931. https://doi.org/10.1016/j.soilbio.2011.01.002

Bergman, I., Lundberg, P., Nilsson, M., 1999. Microbial carbon mineralisation in an acid surface peat: effects of environmental factors in laboratory incubations. Soil Biology and Biochemistry 31, 1867-1877. https://doi.org/10.1016/S0038-0717(99)00117-0

Biederman, L.A., Boutton, T.W., Whisenant, S.G., 2008. Nematode community development early in ecological restoration: The role of organic amendments. Soil Biology and Biochemistry 40, 2366-2374. https://doi.org/10.1016/j.soilbio.2008.05.017

Birkhofer, K., Bezemer, T.M., Bloem, J., Bonkowski, M., Christensen, S., Dubois, D., Ekelund, F., Fließbach, A., Gunst, L., Hedlund, K., Mäder, P., Mikola, J., Robin, C., Setälä, H., Tatin-Froux, F., van der Putten, W.H., Scheu, S., 2008. Long-term organic farming fosters below and aboveground biota: Implications for soil quality, biological control and productivity. Soil Biology and Biochemistry 40, 2297-2308. https://doi.org/10.1016/j.soilbio.2008.05.007

Bloem, J., Lebbink, G., Zwart, K.B., Bouwman, L.A., Burgers, S.L.G.E., de Vos, J.A., de Ruiter, P.C., 1994. Dynamics of microorganisms, microbivores and nitrogen mineralisation in winter wheat fields under conventional and integrated management. Agriculture, Ecosystems \& Environment 51, 129-143. https://doi.org/10.1016/0167-8809(94)90039-6

Bloem, J., Schouten, A.J., Sørensen, S.J., Rutgers, M., van der Werf, A.K., Breure, A.M., 2006. Monitoring and evaluating soil quality, in: Microbiological Methods for Assessing Soil Quality. CABI, Wallingford, UK, pp. 23-49.

Bobbink, R., Hornung, M., Roelofs, J.G.M., 1998. The effects of air-borne nitrogen pollutants on species diversity in natural and semi-natural European vegetation. Journal of Ecology 86, 717-738. https://doi.org/10.1046/j.1365-2745.1998.8650717.x

Bolan, N.S., Adriano, D.C., Curtin, D., 2003. Soil acidification and liming interactions with nutrient and heavy metal transformation and bioavailability. Advances in Agronomy 78, 215-272.

Bolan, N.S., Hedley, M.J., 2003. Role of carbon, nitrogen and sulfur cycles in soil acidification, in: Rengel, Z. (Ed.), Handbook of Soil Acidity. CRC Press, pp. 29-56.

Bonkowski, M., Griffiths, B.S., Ritz, K., 2000. Food preferences of earthworms for soil fungi. Pedobiologia 44, 666-676. https://doi.org/10.1078/S0031-4056(04)70080-3

Borcard, D., Gillet, F., Legendre, P., 2011. Numerical ecology with R, Use R! Springer, New York.

Börjesson, G., Menichetti, L., Kirchmann, H., Kätterer, T., 2012. Soil microbial community structure affected by 53 years of nitrogen fertilisation and different organic amendments. Biology and Fertility of Soils 48, 245-257. https://doi.org/10.1007/s00374-011-0623-8

Bouché, M.B., 1977. Strategies lombriciennes. Ecological Bulletins 25, 122-132.

Bouché, M.B., Al-Addan, F., 1997. Earthworms, water infiltration and soil stability: Some new assessments. Soil Biology and Biochemistry 29, 441-452. https://doi.org/10.1016/S0038-0717(96)00272-6

Bouwman, L.A., Bloem, J., van den Boogert, P.H.J.F., Bremer, F., Hoenderboom, G.H.J., De Ruiter, P.C., 1994. Short-term and long-term effects of bacterivorous nematodes and nematophagous fungi on carbon and nitrogen mineralization in microcosms. Biology and Fertility of Soils 17, 249-256. https://doi.org/10.1007/BF00383977

Breure, A.M., Mulder, C., Römbke, J., Ruf, A., 2005. Ecological classification and assessment concepts in soil protection. Ecotoxicology and Environmental Safety 62, 211-229. https://doi.org/10.1016/j.ecoenv.2005.03.025

Brouns, K., 2016. The effect of climate change on decomposition in Dutch peatlands: an exploration of peat origin and land use effects (PhD thesis). Utrecht University, Utrecht.

Brouns, K., Keuskamp, J.A., Potkamp, G., Verhoeven, J.T.A., Hefting, M.M., 2016. Peat origin and land use effects on microbial activity, respiration dynamics and exo-enzyme activities in drained peat soils in the Netherlands. Soil Biology and Biochemistry 95, 144-155.

https://doi.org/10.1016/j.soilbio.2015.11.018 
Brouns, K., Verhoeven, J.T.A., Hefting, M.M., 2014. Short period of oxygenation releases latch on peat decomposition. Science of The Total Environment 481, 61-68. https://doi.org/10.1016/j.scitotenv.2014.02.030

Brown, G.G., 1995. How do earthworms affect microfloral and faunal community diversity? Plant and Soil 170, 209-231. https://doi.org/10.1007/BF02183068

Brussaard, L., 2012. Ecosystem services provided by the soil biota, in: Wall, D.H., Bardgett, R.D., BehanPelletier, V., Jones, T.H., Ritz, K., Six, J., Strong, D.R., van der Putten, W.H. (Eds.), Soil Ecology and Ecosystem Services. Oxford University Press, Oxford, pp. 45-58.

Brussaard, L., Behan-Pelletier, V.M., Bignell, D.E., Brown, V.K., Didden, W., Folgarait, P., Fragoso, C., WallFreckman, D., Gupta, V.V.S.R., Hattori, T., Hawksworth, D.L., Klopatek, C., Lavelle, P., Malloch, D.W., Rusek, J., Söderström, B., Tiedje, J.M., Virginia, R.A., 1997. Biodiversity and ecosystem functioning in soil. Ambio: a Journal of Human Environment 26, 563-570.

Bünemann, E.K., Schwenke, G.D., Van Zwieten, L., 2006. Impact of agricultural inputs on soil organisms-a review. Australian Journal of Soil Research 44, 379-406. https://doi.org/10.1071/SR05125

Bussink, D.W., Oenema, O., 1998. Ammonia volatilization from dairy farming systems in temperate areas: a review. Nutrient Cycling in Agroecosystems 51, 19-33. https://doi.org/10.1023/A:1009747109538

Butt, K.R., Nuutinen, V., Sirén, T., 2003. Resource distribution and surface activity of adult Lumbricus terrestris L. in an experimental system. Pedobiologia 47, 548-553. https://doi.org/10.1078/0031-4056-00227

Buurman, P., Pape, T., Reijneveld, J.A., de Jong, F., van Gelder, E., 2001. Laser-diffraction and pipette-method grain sizing of Dutch sediments: correlations for fine fractions of marine, fluvial, and loess samples. Netherlands Journal of Geosciences 80, 49-57.

Carter, M.R., 1986. Microbial biomass and mineralizable nitrogen in solonetzic soils: Influence of gypsum and lime amendments. Soil Biology and Biochemistry 18, 531-537. https://doi.org/10.1016/00380717(86)90011-8

Cheshire, M.V., Chapman, S.J., 1996. Influence of the N and P status of plant material and of added N and P on the mineralization of $\mathrm{C}$ from $14 \mathrm{C}$-labelled ryegrass in soil. Biology and Fertility of Soils $21,166-170$. https://doi.org/10.1007/BF00335929

Chow, A.T., Tanji, K.K., Gao, S., Dahlgren, R.A., 2006. Temperature, water content and wet-dry cycle effects on DOC production and carbon mineralization in agricultural peat soils. Soil Biology and Biochemistry 38, 477-488. https://doi.org/10.1016/j.soilbio.2005.06.005

Clocchiatti, A., Hannula, S.E., van den Berg, M., Korthals, G., de Boer, W., 2020. The hidden potential of saprotrophic fungi in arable soil: Patterns of short-term stimulation by organic amendments. Applied Soil Ecology 147, 103434. https://doi.org/10.1016/j.apsoil.2019.103434

Cole, L., Buckland, S.M., Bardgett, R.D., 2005. Relating microarthropod community structure and diversity to soil fertility manipulations in temperate grassland. Soil Biology and Biochemistry 37, 1707-1717. https://doi.org/10.1016/j.soilbio.2005.02.005

Commissie Bemesting Grasland en Voedergewassen, 2019. Fertilization advice (in Dutch). Wageningen Livestock Research, Wageningen.

Costanza, R., d'Arge, R., de Groot, R., Farber, S., Grasso, M., Hannon, B., Limburg, K., Naeem, S., O'Neill, R.V., Paruelo, J., Raskin, R.G., Sutton, P., van den Belt, M., 1997. The value of the world's ecosystem services and natural capital. Nature 387, 253-260. https://doi.org/10.1038/387253a0

Creamer, R.E., Hannula, S.E., van Leeuwen, J.P., Stone, D., Rutgers, M., Schmelz, R.M., de Ruiter, P.C., Hendriksen, N.B., Bolger, T., Bouffaud, M.L., Buee, M., Carvalho, F., Costa, D., Dirilgen, T., Francisco, R., Griffiths, B.S., Griffiths, R., Martin, F., Da Silva, P.M., Mendes, S., Morais, P.V., Pereira, C., Philippot, L., Plassart, P., Redecker, D., Römbke, J., Sousa, J.P., Wouterse, M., Lemanceau, P., 2016. Ecological network analysis reveals the inter-connection between soil biodiversity and ecosystem function as affected by land use across Europe. Applied Soil Ecology 97, 112-124. https://doi.org/10.1016/j.apsoil.2015.08.006

Curry, J.P., 2004. Factors affecting the abundance of earthworms in soils, in: Edwards, C.A. (Ed.), Earthworm Ecology. CRC Press, Boca Raton, USA, pp. 91-113.

Curry, J.P., Schmidt, O., 2007. The feeding ecology of earthworms - A review. Pedobiologia 50, 463-477. https://doi.org/10.1016/j.pedobi.2006.09.001 
Da Silva, A.P., Kay, B.D., Perfect, E., 1994. Characterization of the least limiting water range of soils. Soil Science Society of America Journal 58, 1775-1781. https://doi.org/10.2136/sssaj1994.03615995005800060028x

De Bakker, H., Locher, W.P. (Eds.), 1991. Bodemkunde van Nederland, deel 1: Algemene Bodemkunde. Malmberg, Den Bosch.

De Goede, R.G.M., Brussaard, L., Akkermans, A.D.L., 2003. On-farm impact of cattle slurry manure management on biological soil quality. Netherlands Journal of Agricultural Sciences 51, 103-133.

De Klein, C.A.M., Monaghan, R.M., Sinclair, A.G., 1997. Soil acidification: A provisional model for New Zealand pastoral systems. New Zealand Journal of Agricultural Research 40, 541-557. https://doi.org/10.1080/00288233.1997.9513277

De Ruiter, P.C., Moore, J.C., Zwart, K.B., Bouwman, L.A., Hassink, J., Bloem, J., de Vos, J.A., Marinissen, J.C.Y., Didden, W.A.M., Lebrink, G., Brussaard, L., 1993. Simulation of nitrogen mineralization in the belowground food webs of two winter wheat fields. Journal of Applied Ecology 30, 95-106. https://doi.org/10.2307/2404274

De Vos, J.A., van Bakel, P.J.T., Hoving, I.E., Smidt, R.A., 2010. Raising surface water levels in peat areas with dairy farming. Agricultural Water Management 97, 1887-1897. https://doi.org/10.1016/j.agwat.2010.06.017

De Vries, F., 2004. The occurence of peat soils (in Dutch), in: Van Kekem, A.J. (Ed.), Veengronden en Stikstof Leverend Vermogen, Report 965. Alterra, Wageningen, pp. 15-24.

De Vries, F.T., Hoffland, E., van Eekeren, N., Brussaard, L., Bloem, J., 2006. Fungal/bacterial ratios in grasslands with contrasting nitrogen management. Soil Biology and Biochemistry 38, 2092-2103. https://doi.org/10.1016/j.soilbio.2006.01.008

De Vries, F.T., Thébault, E., Liiri, M., Birkhofer, K., Tsiafouli, M.A., Bjørnlund, L., Jørgensen, H.B., Brady, M.V., Christensen, S., de Ruiter, P.C., d'Hertefeldt, T., Frouz, J., Hedlund, K., Hemerik, L., Hol, W.H.G., Hotes, S., Mortimer, S.R., Setälä, H., Sgardelis, S.P., Uteseny, K., van der Putten, W.H., Wolters, V., Bardgett, R.D., 2013. Soil food web properties explain ecosystem services across European land use systems. Proceedings of the National Academy of Sciences 110, 14296-14301. https://doi.org/10.1073/pnas.1305198110

DeConto, R.M., Pollard, D., Alley, R.B., Velicogna, I., Gasson, E., Gomez, N., Sadai, S., Condron, A., Gilford, D.M., Ashe, E.L., Kopp, R.E., Li, D., Dutton, A., 2021. The Paris Climate Agreement and future sea-level rise from Antarctica. Nature 593, 83-89. https://doi.org/10.1038/s41586-021-03427-0

Dekker, L.W., Ritsema, C.J., 2000. Wetting patterns and moisture variability in water repellent Dutch soils. Journal of Hydrology 231-232, 148-164. https://doi.org/10.1016/S0022-1694(00)00191-8

Deru, J.G.C., Bloem, J., de Goede, R., Hoekstra, N., Keidel, H., Kloen, H., Nierop, A., Rutgers, M., Schouten, T., van den Akker, J., Brussaard, L., van Eekeren, N., 2019. Predicting soil N supply and yield parameters in peat grasslands. Applied Soil Ecology 134, 77-84. https://doi.org/10.1016/j.apsoil.2018.10.018

Deru, J.G.C., Bloem, J., de Goede, R., Keidel, H., Kloen, H., Rutgers, M., van den Akker, J., Brussaard, L., van Eekeren, N., 2018a. Soil ecology and ecosystem services of dairy and semi-natural grasslands on peat. Applied Soil Ecology 125, 26-34. https://doi.org/10.1016/j.apsoil.2017.12.011

Deru, J.G.C., Hensen, A., van Dinther, D., Frumau, A., van den Bulk, P., Antonissen, H., 2018b. Exploratory ammonia and methane measurements in the "Kwatrijn" stable (in Dutch) (Report 021-LbD). Louis Bolk Institute, Bunnik.

Dettmann, U., Bechtold, M., Frahm, E., Tiemeyer, B., 2014. On the applicability of unimodal and bimodal van Genuchten-Mualem based models to peat and other organic soils under evaporation conditions. Journal of Hydrology 515, 103-115. https://doi.org/10.1016/j.jhydrol.2014.04.047

Didden, W.A.M., Marinissen, J.C.Y., Vreeken-Buijs, M.J., Burgers, S.L.G.E., de Fluiter, R., Geurs, M., Brussaard, L., 1994. Soil meso- and macrofauna in two agricultural systems: factors affecting population dynamics and evaluation of their role in carbon and nitrogen dynamics. Agriculture, Ecosystems \& Environment 51, 171-186. https://doi.org/10.1016/0167-8809(94)90042-6

Doerr, S.H., Shakesby, R.A., Walsh, R.P.D., 2000. Soil water repellency: its causes, characteristics and hydrogeomorphological significance. Earth-Science Reviews 51, 33-65. https://doi.org/10.1016/S00128252(00)00011-8 
Dominati, E., Patterson, M., Mackay, A., 2010. A framework for classifying and quantifying the natural capital and ecosystem services of soils. Ecological Economics 69, 1858-1868. https://doi.org/10.1016/j.ecolecon.2010.05.002

Dontsova, K.M., Norton, L.D., 2002. Clay dispersion, infiltration, and erosion as influenced by exchangeable Ca and Mg. Soil Science 167, 184-193. https://doi.org/10.1097/00010694-200203000-00003

Edouard, N., Charpiot, A., Robin, P., Lorinquer, E., Dollé, J.-B., Faverdin, P., 2019. Influence of diet and manure management on ammonia and greenhouse gas emissions from dairy barns. Animal 13, 2903-2912. https://doi.org/10.1017/S1751731119001368

Edwards, C.A., Bohlen, P.J., 1996. Biology and Ecology of Earthworms, 3rd ed. Chapman \& Hall, London.

Edwards, C.A., Lofty, J.R., 1982. Nitrogenous fertilizers and earthworm populations in agricultural soils. Soil Biology and Biochemistry 14, 515-521. https://doi.org/10.1016/0038-0717(82)90112-2

Egnér, H., Riehm, H., Dominigo, W., 1960. Untersuchungen über die chemische Bodenanalyse als Grundlage für die Beurteilung des Nährstoff zustandes der Böden. II. Chemische Extraktionsmethoden zur Phosphorund Kaliumbestimmung. Kungliga Lantbrukshögskolans Annaler 26, 199-215.

Ekschmitt, K., Griffiths, B.S., 1998. Soil biodiversity and its implications for ecosystem functioning in a heterogeneous and variable environment. Applied Soil Ecology 10, 201-215. https://doi.org/10.1016/S0929-1393(98)00119-X

Elbanna, E.B., Witney, B.D., 1987. Cone penetration resistance equation as a function of the clay ratio, soil moisture content and specific weight. Journal of Terramechanics 24, 41-56. https://doi.org/10.1016/0022-4898(87)90058-9

Erisman, J.W., Brasseur, G., Ciais, P., van Eekeren, N., Theis, T.L., 2015. Global change: Put people at the centre of global risk management. Nature News 519, 151. https://doi.org/10.1038/519151a

Erisman, J.W., van Eekeren, N., de Wit, J., Koopmans, C., Oerlemans, N., Koks, B., 2016. Agriculture and biodiversity: a better balance benefits both. AIMS Agriculture and Food 1, 157-174. https://doi.org/10.3934/agrfood.2016.2.157

Ettema, C.H., Wardle, D.A., 2002. Spatial soil ecology. Trends in Ecology \& Evolution 17, 177-183. https://doi.org/10.1016/S0169-5347(02)02496-5

Fanin, N., Kardol, P., Farrell, M., Nilsson, M.-C., Gundale, M.J., Wardle, D.A., 2019. The ratio of Gram-positive to Gram-negative bacterial PLFA markers as an indicator of carbon availability in organic soils. Soil Biology and Biochemistry 128, 111-114. https://doi.org/10.1016/j.soilbio.2018.10.010

FAO, 2015. World reference base for soil resources 2014. International soil classification system for naming soils and creating legends for soil maps. (Update 2015 No. 106), World soil resources reports. Food and Agriculture Organization of the United Nations, Rome.

FAO, 2014. World reference base for soil resources 2014: international soil classification system for naming soils and creating legends for soil maps. Food and Agriculture Organization of the United Nations, Rome.

Fernández-Calviño, D., Bååth, E., 2010. Growth response of the bacterial community to pH in soils differing in pH. FEMS Microbiology Ecology 73, 149-156. https://doi.org/10.1111/j.1574-6941.2010.00873.x

Ferris, H., Bongers, T., de Goede, R.G.M., 2001. A framework for soil food web diagnostics: extension of the nematode faunal analysis concept. Applied Soil Ecology 18, 13-29. https://doi.org/10.1016/S09291393(01)00152-4

Fierer, N., Jackson, R.B., 2006. The diversity and biogeography of soil bacterial communities. Proceedings of the National Academy of Sciences 103, 626-631. https://doi.org/10.1073/pnas.0507535103

Finlay, B.J., Black, H.I.J., Brown, S., Clarke, K.J., Esteban, G.F., Hindle, R.M., Olmo, J.L., Rollett, A., Vickerman, K., 2000. Estimating the growth potential of the soil protozoan community. Protist 151, 69-80. https://doi.org/10.1078/1434-4610-00008

Fisher, B., Turner, R.K., Morling, P., 2009. Defining and classifying ecosystem services for decision making. Ecological Economics 68, 643-653. https://doi.org/10.1016/j.ecolecon.2008.09.014

Fisher, R.A., Corbet, A.S., Williams, C.B., 1943. The relation between the number of species and the number of individuals in a random sample of an animal population. Journal of Animal Ecology 12, 42-58. https://doi.org/10.2307/1411

Gad, H., Wachendorf, C., Joergensen, R.G., 2015. Response of maize and soil microorganisms to decomposing poplar root residues after shallow or homogenous mixing into soil. Journal of Plant Nutrition and Soil Science 178, 507-514. https://doi.org/10.1002/jpln.201400593 
Galbraith, H., 1989. Arrival and habitat use by Lapwings Vanellus vanellus in the early breeding season. Ibis 131, 377-388. https://doi.org/10.1111/j.1474-919X.1989.tb02786.x

Gebrezgabher, S.A., Meuwissen, M.P.M., Kruseman, G., Lakner, D., Lansink, A.G.J.M.O., 2015. Factors influencing adoption of manure separation technology in the Netherlands. Journal of Environmental Management 150, 1-8. https://doi.org/10.1016/j.jenvman.2014.10.029

Ghani, A., Dexter, M., Perrott, K.W., 2003. Hot-water extractable carbon in soils: a sensitive measurement for determining impacts of fertilisation, grazing and cultivation. Soil Biology and Biochemistry 35, 12311243. https://doi.org/10.1016/S0038-0717(03)00186-X

Goulding, K.W.T., 2016. Soil acidification and the importance of liming agricultural soils with particular reference to the United Kingdom. Soil Use and Management 32, 390-399. https://doi.org/10.1111/sum.12270

Grover, S.P., Butterly, C.R., Wang, X., Tang, C., 2017. The short-term effects of liming on organic carbon mineralisation in two acidic soils as affected by different rates and application depths of lime. Biology and Fertility of Soils 53, 431-443. https://doi.org/10.1007/s00374-017-1196-y

Guerrero, C., Moral, R., Gómez, I., Zornoza, R., Arcenegui, V., 2007. Microbial biomass and activity of an agricultural soil amended with the solid phase of pig slurries. Bioresource Technology 98, 3259-3264. https://doi.org/10.1016/j.biortech.2006.07.015

Hamilton, S.K., Kurzman, A.L., Arango, C., Jin, L., Robertson, G.P., 2007. Evidence for carbon sequestration by agricultural liming. Global Biogeochemical Cycles 21, 1-12. https://doi.org/10.1029/2006GB002738

Hansen, S., Engelstad, F., 1999. Earthworm populations in a cool and wet district as affected by tractor traffic and fertilisation. Applied Soil Ecology 13, 237-250. https://doi.org/10.1016/S0929-1393(99)00037-2

Hassink, J., 1996. Predicting the nitrogen supply of grassland soils (in Dutch), in: Loonen, J.W.G.M., Bach-de Wit, W.E.M. (Eds.), Stikstof in Beeld: Naar Een Nieuw Bemestingsadvies Op Grasland, Onderzoek Inzake de Mest- En Ammoniakproblematiek in de Veehouderij. Wageningen DLO, Ede, pp. 15-35.

Hassink, J., 1995a. Organic matter dynamics and N mineralization in grassland soils (PhD thesis). Wageningen University, Wageningen.

Hassink, J., 1995b. Prediction of the non-fertilizer N supply of mineral grassland soils. Plant Soil 176, 71-79. https://doi.org/10.1007/BF00017677

Haynes, R.J., 2005. Labile organic matter fractions as central components of the quality of agricultural soils: an overview. Advances in agronomy 85, 221-268.

Haynes, R.J., 1984. Lime and Phosphate in the Soil-Plant System, in: Brady, N.C. (Ed.), Advances in Agronomy. Academic Press, London, pp. 249-315.

Haynes, R.J., Naidu, R., 1998. Influence of lime, fertilizer and manure applications on soil organic matter content and soil physical conditions: a review. Nutrient Cycling in Agroecosystems 51, 123-137. https://doi.org/10.1023/A:1009738307837

Hedlund, K., 2002. Soil microbial community structure in relation to vegetation management on former agricultural land. Soil Biology and Biochemistry 34, 1299-1307. https://doi.org/10.1016/S00380717(02)00073-1

Hjorth, M., Christensen, K.V., Christensen, M.L., Sommer, S.G., 2010. Solid-liquid separation of animal slurry in theory and practice. A review. Agronomy for Sustainable Development 30, 153-180. https://doi.org/10.1051/agro/2009010

Hodge, A., Robinson, D., Fitter, A., 2000. Are microorganisms more effective than plants at competing for nitrogen? Trends in Plant Science 5, 304-308. https://doi.org/10.1016/S1360-1385(00)01656-3

Hoekstra, N., Holshof, G., Schils, R., Philipsen, B., van Reenen, K., van Houwelingen, K., van Eekeren, N., 2019. The effect of kurzrasen and strip-grazing on grassland performance and soil quality of a peat meadow. Sustainability 11, 6283. https://doi.org/10.3390/su11226283

Högstedt, G., 1974. Length of the pre-laying period in the Lapwing Vanellus vanellus L. in relation to its food resources. Ornis Scandinavica (Scandinavian Journal of Ornithology) 5, 1-4. https://doi.org/10.2307/3675888

Holden, J., 2005. Peatland hydrology and carbon release: why small-scale process matters. Philosophical Transactions of the Royal Society of London A: Mathematical, Physical and Engineering Sciences 363, 2891-2913. https://doi.org/10.1098/rsta.2005.1671 
Holland, J.E., Bennett, A.E., Newton, A.C., White, P.J., McKenzie, B.M., George, T.S., Pakeman, R.J., Bailey, J.S., Fornara, D.A., Hayes, R.C., 2018. Liming impacts on soils, crops and biodiversity in the UK: A review. Science of The Total Environment 610-611, 316-332. https://doi.org/10.1016/j.scitotenv.2017.08.020

Houba, V.J.G., van der Lee, J.J.G., Novozamsky, I., 1997. Soil and plant analysis: Soil analysis procedures, Soil and plant analysis. Wageningen University, Wageningen.

Hoyt, P.B., 1981. Improvements in soil tilth and rapeseed emergence by lime applications on acid soils in the peace river region. Canadian Journal of Soil Science 61, 91-98. https://doi.org/10.4141/cjss81-010

Huijsmans, J.F.M., Hol, J.M.G., Hendriks, M.M.W.B., 2001. Effect of application technique, manure characteristics, weather and field conditions on ammonia volatilization from manure applied to grassland. Netherlands Journal of Agricultural Sciences 49, 323-342. https://doi.org/10.1016/S15735214(01)80021-X

Jacobs, C.M.J., Jacobs, A.F.G., Bosveld, F.C., Hendriks, D.M.D., Hensen, A., Kroon, P.S., Moors, E.J., Nol, L., Schrier-Uijl, A., Veenendaal, E.M., 2007. Variability of annual CO2 exchange from Dutch grasslands. Biogeosciences Discussions 4, 1499-1534.

Jänsch, S., Römbke, J., Didden, W., 2005. The use of enchytraeids in ecological soil classification and assessment concepts. Ecotoxicology and Environmental Safety 62, 266-277. https://doi.org/10.1016/j.ecoenv.2004.10.025

Joosten, H., 2011. The global peatland CO2 picture, in: Tanneberger, F., Wichtmann, W. (Eds.), Carbon Credits from Peatland Rewetting. Climate - Biodiversity - Land Use. Schweizerbart Science Publishers, Stuttgart, Germany, pp. 20-29.

Kalisz, B., Lachacz, A., Glazewski, R., 2010. Transformation of some organic matter components in organic soils exposed to drainage. Turkish Journal of Agriculture and Forestry 34, 245-256.

Kallenbach, C.M., Frey, S.D., Grandy, A.S., 2016. Direct evidence for microbial-derived soil organic matter formation and its ecophysiological controls. Nature Communications 7, 13630. https://doi.org/10.1038/ncomms13630

Kasimir-Klemedtsson, Å., Klemedtsson, L., Berglund, K., Martikainen, P., Silvola, J., Oenema, O., 1997. Greenhouse gas emissions from farmed organic soils: a review. Soil Use and Management 13, 245250. https://doi.org/10.1111/j.1475-2743.1997.tb00595.x

Kechavarzi, C., Dawson, Q., Bartlett, M., Leeds-Harrison, P.B., 2010. The role of soil moisture, temperature and nutrient amendment on $\mathrm{CO} 2$ efflux from agricultural peat soil microcosms. Geoderma 154, 203-210. https://doi.org/10.1016/j.geoderma.2009.02.018

Kentie, R., Both, C., Hooijmeijer, J.C.E.W., Piersma, T., 2015. Management of modern agricultural landscapes increases nest predation rates in Black-tailed Godwits Limosa limosa. Ibis 157, 614-625. https://doi.org/10.1111/ibi.12273

Keuskamp, J.A., Dingemans, B.J.J., Lehtinen, T., Sarneel, J.M., Hefting, M.M., 2013. Tea Bag Index: a novel approach to collect uniform decomposition data across ecosystems. Methods in Ecology and Evolution 4, 1070-1075. https://doi.org/10.1111/2041-210X.12097

King, K.L., Hutchinson, K.J., 1980. Effects of superphosphate and stocking intensity on grassland microarthropods. Journal of Applied Ecology 17, 581-591. https://doi.org/10.2307/2402638

Kleijn, D., Berendse, F., Smit, R., Gilissen, N., 2001. Agri-environment schemes do not effectively protect biodiversity in Dutch agricultural landscapes. Nature 413, 723-725. https://doi.org/10.1038/35099540

Kline, R.B., 2016. Principles and Practice of Structural Equation Modeling, 4th ed. The Guilford Press, New York.

Klingenfuß, C., Roßkopf, N., Walter, J., Heller, C., Zeitz, J., 2014. Soil organic matter to soil organic carbon ratios of peatland soil substrates. Geoderma 235-236, 410-417. https://doi.org/10.1016/j.geoderma.2014.07.010

Klok, C., Faber, J., Heijmans, G., Bodt, J., van der Hout, A., 2007. Influence of clay content and acidity of soil on development of the earthworm Lumbricus rubellus and its population level consequences. Biology and Fertility of Soils 43, 549-556. https://doi.org/10.1007/s00374-006-0135-0

Kluge, B., Wessolek, G., Facklam, M., Lorenz, M., Schwärzel, K., 2008. Long-term carbon loss and CO2-C release of drained peatland soils in northeast Germany. European Journal of Soil Science 59, 1076-1086. https://doi.org/10.1111/j.1365-2389.2008.01079.x

KNMI, 2014. Climate Change scenarios for the 21st Century - A Netherlands perspective (Scientific report No. WR 2014-01). KNMI, De Bilt. 
KNMI, 2010. Monthly overview of the weather in 2010 in the Netherlands (in Dutch) [WWW Document]. URL www.knmi.nl/nederland-nu/klimatologie/gegevens/mow

Koerselman, W., van Kerkhoven, M.B., verhoeven, J.T., 1993. Release of inorganic N, P and K in peat soils; effect of temperature, water chemistry and water level. Biogeochemistry 20, 63-81. https://doi.org/10.1007/BF00004135

Kolay, P.K., Pui, M.P., 2010. Peat stabilization using gypsum and fly ash. Journal of Civil Engineering, Science and Technology 1, 1-5. https://doi.org/10.33736/jcest.75.2010

Kools, S.A.E., 2006. Soil ecosystem toxicology : metal effects on structure and function (PhD thesis). Vrije Universiteit, Amsterdam.

Kopittke, P.M., Menzies, N.W., 2007. A review of the use of the basic cation saturation ratio and the "ideal" soil. Soil Science Society of America Journal 71, 259-265. https://doi.org/10.2136/sssaj2006.0186

Kramer, C., Gleixner, G., 2008. Soil organic matter in soil depth profiles: Distinct carbon preferences of microbial groups during carbon transformation. Soil Biology and Biochemistry 40, 425-433. https://doi.org/10.1016/j.soilbio.2007.09.016

Kroeze, C., Aerts, R., van Breemen, N., van Dam, D., Hofschreuder, P., Hoosbeek, M., de Klein, J., van der Hoek, K., Kros, H., van Oene, H., Oenema, O., Tietema, A., van der Veeren, R., de Vries, W., 2003. Uncertainties in the fate of nitrogen I: An overview of sources of uncertainty illustrated with a Dutch case study. Nutrient Cycling in Agroecosystems 66, 43-69. https://doi.org/10.1023/A:1023339106213

Krüger, J.P., Leifeld, J., Glatzel, S., Szidat, S., Alewell, C., 2015. Biogeochemical indicators of peatland degradation - a case study of a temperate bog in northern Germany. Biogeosciences 12, 2861-2871. https://doi.org/10.5194/bg-12-2861-2015

Kruk, M., Noordervliet, M.A.W., ter Keurs, W.J., 1996. Hatching dates of waders and mowing dates in intensively exploited grassland areas in different years. Biological Conservation 77, 213-218. https://doi.org/10.1016/0006-3207(95)00128-X

Lal, R., 2008. Carbon sequestration. Philosophical Transactions of the Royal Society of London B: Biological Sciences 363, 815-830. https://doi.org/10.1098/rstb.2007.2185

Lamers, L.P.M., Smolders, A.J.P., Roelofs, J.G.M., 2002. The restoration of fens in the Netherlands. Hydrobiologia 478, 107-130. https://doi.org/10.1023/A:1021022529475

Lavelle, P., 1997. Faunal activities and soil processes: Adaptive strategies that determine ecosystem function. Advances in Ecological Research 27, 93-132.

Lavelle, P., Decaëns, T., Aubert, M., Barot, S., Blouin, M., Bureau, F., Margerie, P., Mora, P., Rossi, J.-P., 2006. Soil invertebrates and ecosystem services. European Journal of Soil Biology 42, S3-S15. https://doi.org/10.1016/j.ejsobi.2006.10.002

Leroy, B.L.M., Schmidt, O., Van den Bossche, A., Reheul, D., Moens, M., 2008. Earthworm population dynamics as influenced by the quality of exogenous organic matter. Pedobiologia 52, 139-150. https://doi.org/10.1016/j.pedobi.2008.07.001

Levi-Minzi, R., Riffaldi, R., Saviozzi, A., 1986. Organic matter and nutrients in fresh and mature farmyard manure. Agricultural Wastes 16, 225-236. https://doi.org/10.1016/0141-4607(86)90068-5

Loranger, G., Ponge, J.F., Blanchart, E., Lavelle, P., 1998. Impact of earthworms on the diversity of microarthropods in a vertisol (Martinique). Biology and Fertility of Soils 27, 21-26. https://doi.org/10.1007/s003740050394

Lubbers, I.M., Pulleman, M.M., Van Groenigen, J.W., 2017. Can earthworms simultaneously enhance decomposition and stabilization of plant residue carbon? Soil Biology and Biochemistry 105, 12-24. https://doi.org/10.1016/j.soilbio.2016.11.008

Lynch, J.P., Wojciechowski, T., 2015. Opportunities and challenges in the subsoil: pathways to deeper rooted crops. Journal of Experimental Botany 66, 2199-2210. https://doi.org/10.1093/jxb/eru508

Ma, W.-C., Brussaard, L., de Ridder, J.A., 1990. Long-term effects of nitrogenous fertilizers on grassland earthworms (Oligochaeta: Lumbricidae): Their relation to soil acidification. Agriculture, Ecosystems \& Environment 30, 71-80. https://doi.org/10.1016/0167-8809(90)90184-F

Macdonald, D.W., 1983. Predation on earthworms by terrestrial vertebrates, in: Satchell, J.E. (Ed.), Earthworm Ecology: From Darwin to Vermiculture. Springer Netherlands, Dordrecht, pp. 393-414. https://doi.org/10.1007/978-94-009-5965-1_35 
Malley, D.F., Yesmin, L., Wray, D., Edwards, S., 1999. Application of near-infrared spectroscopy in analysis of soil mineral nutrients. Communications in Soil Science and Plant Analysis 30, 999-1012. https://doi.org/10.1080/00103629909370263

Maltby, E., Immirzi, P., 1993. Carbon dynamics in peatlands and other wetland soils - regional and global perspectives. Chemosphere 27, 999-1023. https://doi.org/10.1016/0045-6535(93)90065-D

Månsson, K., Bengtson, P., Falkengren-Grerup, U., Bengtsson, G., 2009. Plant-microbial competition for nitrogen uncoupled from soil C:N ratios. Oikos 118, 1908-1916. https://doi.org/10.1111/j.16000706.2009.17796.x

Mao, J., Nierop, K.G.J., Sinninghe Damsté, J.S., Dekker, S.C., 2014. Roots induce stronger soil water repellency than leaf waxes. Geoderma 232-234, 328-340. https://doi.org/10.1016/j.geoderma.2014.05.024

Marschner, B., Wilczynski, A.W., 1991. The effect of liming on quantity and chemical composition of soil organic matter in a pine forest in Berlin, Germany. Plant and Soil 137, 229-236. https://doi.org/10.1007/BF00011201

McCallum, H.M., Park, K.J., O’brien, M.G., Gimona, A., Poggio, L., Wilson, J.D., 2015. Soil pH and organic matter content add explanatory power to Northern Lapwing Vanellus vanellus distribution models and suggest soil amendment as a conservation measure on upland farmland. Ibis 157, 677-687. https://doi.org/10.1111/ibi.12286

McCallum, H.M., Wilson, J.D., Beaumont, D., Sheldon, R., O’Brien, M.G., Park, K.J., 2016. A role for liming as a conservation intervention? Earthworm abundance is associated with higher soil $\mathrm{pH}$ and foraging activity of a threatened shorebird in upland grasslands. Agriculture, Ecosystems and Environment 223, 182-189. https://doi.org/10.1016/j.agee.2016.03.005

MEA, 2005. Millennium Ecosystem Assessment: Ecosystems and Human Well-being: Current Status and Trends: Findings of the Condition and Trends Working Group. Island Press, Washington DC.

Mehlich, A., 1984. Mehlich 3 soil test extractant: A modification of Mehlich 2 extractant. Communications in Soil Science and Plant Analysis 15, 1409-1416. https://doi.org/10.1080/00103628409367568

Minasny, B., Malone, B.P., McBratney, A.B., Angers, D.A., Arrouays, D., Chambers, A., Chaplot, V., Chen, Z.-S., Cheng, K., Das, B.S., Field, D.J., Gimona, A., Hedley, C.B., Hong, S.Y., Mandal, B., Marchant, B.P., Martin, M., McConkey, B.G., Mulder, V.L., O’Rourke, S., Richer-de-Forges, A.C., Odeh, I., Padarian, J., Paustian, K., Pan, G., Poggio, L., Savin, I., Stolbovoy, V., Stockmann, U., Sulaeman, Y., Tsui, C.-C., Vågen, T.-G., van Wesemael, B., Winowiecki, L., 2017. Soil carbon 4 per mille. Geoderma 292, 59-86. https://doi.org/10.1016/j.geoderma.2017.01.002

Ministry of Economic Affairs and Climate Policy, 2019. Climate Deal (in Dutch: Klimaatakkoord) [WWW Document]. URL www.klimaatakkoord.nl/documenten/publicaties/2019/06/28/klimaatakkoord

Morley, C.P., Mainwaring, K.A., Doerr, S.H., Douglas, P., Llewellyn, C.T., Dekker, L.W., 2005. Organic compounds at different depths in a sandy soil and their role in water repellency. Australiand Journal of Soil Research 43, 239-249.

Mulder, C., Elser, J.J., 2009. Soil acidity, ecological stoichiometry and allometric scaling in grassland food webs. Global Change Biology 15, 2730-2738. https://doi.org/10.1111/j.1365-2486.2009.01899.x

Muldowney, J., Curry, J.P., O’Keeffe, J., Schmidt, O., 2003. Relationships between earthworm populations, grassland management and badger densities in County Kilkenny, Ireland. Pedobiologia 47, 913-919. https://doi.org/10.1078/0031-4056-00280

Murphy, P.N.C., 2007. Lime and cow slurry application temporarily increases organic phosphorus mobility in an acid soil. European Journal of Soil Science 58, 794-801. https://doi.org/10.1111/j.13652389.2006.00869.x

Murphy, P.N.C., Stevens, R.J., 2010. Lime and gypsum as source measures to decrease phosphorus loss from soils to water. Water, Air \& Soil Pollution 212, 101-111. https://doi.org/10.1007/s11270-010-0325-0

Neale, S.P., Shah, Z., Adams, W.A., 1997. Changes in microbial biomass and nitrogen turnover in acidic organic soils following liming. Soil Biology and Biochemistry 29, 1463-1474. https://doi.org/10.1016/S00380717(97)00040-0

Newell Price, J.P., Balshaw, H., Chambers, B.J., 2014. Managing grasslands to mitigate flooding risk, in: Hopkins, A., Collins, R.P., Fraser, M.D., King, V.R., Lloyd, D.C., Moorby, G.M., Robson, P.R.H. (Eds.), EGF at 50: The Future of European Grasslands, European Science in Europe. European Grassland Federation, Aberystwyth, pp. 270-272.

Onrust, J., 2017. Earth, worms \& birds (PhD thesis). Rijksuniversiteit Groningen, Groningen. 
Onrust, J., Loonstra, A.H.J., Schmaltz, L.E., Verkuil, Y.I., Hooijmeijer, J.C.E.W., Piersma, T., 2017. Detection of earthworm prey by Ruff Philomachus pugnax. Ibis 159, 647-656. https://doi.org/10.1111/ibi.12467

Onrust, J., Piersma, T., 2019. How dairy farmers manage the interactions between organic fertilizers and earthworm ecotypes and their predators. Agriculture, Ecosystems \& Environment 273, 80-85. https://doi.org/10.1016/j.agee.2018.12.005

Onrust, J., Piersma, T., 2017. The Hungry Worm Feeds the Bird. Ardea 105, 153-161. https://doi.org/10.5253/arde.v105i2.a4

Onrust, J., Wymenga, E., Piersma, T., Olff, H., 2019. Earthworm activity and availability for meadow birds is restricted in intensively managed grasslands. Journal of Applied Ecology 56, 1333-1342. https://doi.org/10.1111/1365-2664.13356

Oosterveld, E., 2006. The significance of water levels and fertilization for meadow birds (in Dutch). De Levende Natuur 107, 134-137.

Oste, L.A., Temminghoff, E.J.M., van Riemsdijk, W.H., 2002. Solid-solution partitioning of organic matter in soils as influenced by an increase in pH or Ca concentration. Environmental Science \& Technology 36, 208214. https://doi.org/10.1021/es0100571

Palojärvi, A., 2006. Phospholipid fatty acid (PLFA) analyses, in: Bloem, J., Hopkins, D.W., Benedetti, A. (Eds.), Microbiological Methods for Assessing Soil Quality. CABI, Wallingford, UK, pp. 204-211.

Paradelo, R., Virto, I., Chenu, C., 2015. Net effect of liming on soil organic carbon stocks: A review. Agriculture, Ecosystems \& Environment 202, 98-107. https://doi.org/10.1016/j.agee.2015.01.005

Parfitt, R.L., Yeates, G.W., Ross, D.J., Schon, N.L., Mackay, A.D., Wardle, D.A., 2010. Effect of fertilizer, herbicide and grazing management of pastures on plant and soil communities. Applied Soil Ecology 45, 175-186. https://doi.org/10.1016/j.apsoil.2010.03.010

Parish, F., Sirin, A., Charman, D., Joosten, H., Minayeva, T., Silvius, M., Stringer, L. (Eds.), 2008. Assessment on peatlands, biodiversity and climate change: main report. Global Environment Centre and Wetlands International, Kuala Lumpur and Wageningen.

Paterson, E., Osler, G., Dawson, L.A., Gebbing, T., Sim, A., Ord, B., 2008. Labile and recalcitrant plant fractions are utilised by distinct microbial communities in soil: Independent of the presence of roots and mycorrhizal fungi. Soil Biology and Biochemistry 40, 1103-1113. https://doi.org/10.1016/j.soilbio.2007.12.003

Peerlkamp, P.K., 1959. A visual method of soil structure evaluation. Mededelingen van de Landbouwhogeschool en der opzoekingsstations van den Staat te Gent 24, 216-221.

Persson, T., Bååth, E., Clarholm, M., Lundkvist, H., Söderström, B.E., Sohlenius, B., 1980. Trophic structure, biomass dynamics and carbon metabolism of soil organisms in a Scots pine forest. Ecological Bulletins 419-459.

Peters, K., Jensen, L.S., 2011. Biochemical characteristics of solid fractions from animal slurry separation and their effects on $\mathrm{C}$ and $\mathrm{N}$ mineralisation in soil. Biology and Fertility of Soils 47, 447-455. https://doi.org/10.1007/s00374-011-0550-8

Pijlman, J., Berger, S.J., Lexmond, F., Bloem, J., van Groenigen, J.W., Visser, E.J.W., Erisman, J.W., van Eekeren, N., 2019. Can the presence of plantain (Plantago lanceolata L.) improve nitrogen cycling of dairy grassland systems on peat soils? New Zealand Journal of Agricultural Research 63, 106-122. https://doi.org/10.1080/00288233.2019.1698620

Pijlman, J., de Wit, J., Deru, J., van Agtmaal, M., Wagenaar, J.P., Erisman, J.W., van Eekeren, N., 2018. Living lab Climate max farm - Preliminary study on scenarios for a farm on peat with minimal climate impact (in Dutch) (Report 029 LbD). Louis Bolk Institute, Bunnik.

Pijlman, J., Holshof, G., van den Berg, W., Ros, G.H., Erisman, J.W., van Eekeren, N., 2020. Soil nitrogen supply of peat grasslands estimated by degree days and soil organic matter content. Nutrient Cycling in Agroecosystems 117, 351-365. https://doi.org/10.1007/s10705-020-10071-z

Plum, N.M., Filser, J., 2005. Floods and drought: Response of earthworms and potworms (Oligochaeta: Lumbricidae, Enchytraeidae) to hydrological extremes in wet grassland. Pedobiologia 49, 443-453. https://doi.org/10.1016/j.pedobi.2005.05.004

Pörtner, H.-O., Roberts, D.C., Masson-Delmotte, V., Zhai, P., Tignor, M., Poloczanska, E., Mintenbeck, K., Nicolai, M., Okem, A., Petzold, J., 2019. IPCC special report on the ocean and cryosphere in a changing climate (No. 1(3)). Geneva, Switzerland. 
Pribyl, D.W., 2010. A critical review of the conventional SOC to SOM conversion factor. Geoderma 156, 75-83. https://doi.org/10.1016/j.geoderma.2010.02.003

Rashid, M.I., 2013. Soil biota and nitrogen cycling in production grasslands with different fertilisation histories (PhD thesis). Wageningen University, Wageningen.

Rashid, M.I., de Goede, R.G.M., Brussaard, L., Bloem, J., Lantinga, E.A., 2014a. Production-ecological modelling explains the difference between potential soil $\mathrm{N}$ mineralisation and actual herbage $\mathrm{N}$ uptake. Applied Soil Ecology 84, 83-92. https://doi.org/10.1016/j.apsoil.2014.07.002

Rashid, M.I., de Goede, R.G.M., Corral Nunez, G.A., Brussaard, L., Lantinga, E.A., 2014b. Soil pH and earthworms affect herbage nitrogen recovery from solid cattle manure in production grassland. Soil Biology and Biochemistry 68, 1-8. https://doi.org/10.1016/j.soilbio.2013.09.013

Reeve, M.F., Sumner, N.G., 1972. Amelioration of subsoil acidity in Natal Oxisols by leaching of surface-applied amendments. Agrochemophysica 4, 1-5.

Reijneveld, A., Termorshuizen, A., Vedder, H., Oenema, O., 2014. Strategy for innovation in soil tests illustrated for $\mathrm{P}$ tests. Communications in Soil Science and Plant Analysis 45, 498-515. https://doi.org/10.1080/00103624.2013.863909

Rienks, W., Gerritsen, A.L., Meulenkamp, W.J.H., 2002. Preserving peat meadow area: a spatial exploration (in Dutch) (No. 563). Alterra, Wageningen.

Ritzema, H.P., Stuyt, L.C.P.M., 2015. Land drainage strategies to cope with climate change in the Netherlands. Acta Agriculturae Scandinavica, Section B - Soil \& Plant Science 65, 80-92. https://doi.org/10.1080/09064710.2014.994557

Ross, D.S., Ketterings, Q., 1995. Recommended methods for determining soil cation exchange capacity, in: Recommended Soil Testing Procedures for the Northeastern United States, Northeastern Regional Bulletin. Ag Experiment Station, University of Delaware, Newark, USA, pp. 75-86.

Rosseel, 2012. lavaan: An R package for structural equation modeling. Journal of statistical software 48, 1-36. https://doi.org/10.18637/jss.v048.i02

Rousk, J., Brookes, P.C., Bååth, E., 2011. Fungal and bacterial growth responses to $\mathrm{N}$ fertilization and $\mathrm{pH}$ in the 150-year 'Park Grass' UK grassland experiment. FEMS Microbiology Ecology 76, 89-99. https://doi.org/10.1111/j.1574-6941.2010.01032.x

Rowley, M.C., Grand, S., Verrecchia, É.P., 2018. Calcium-mediated stabilisation of soil organic carbon. Biogeochemistry 137, 27-49. https://doi.org/10.1007/s10533-017-0410-1

Royston, J.P., 1982. Algorithm AS 181: The W Test for Normality. Journal of the Royal Statistical Society. Series C (Applied Statistics) 31, 176-180. https://doi.org/10.2307/2347986

Rühlmann, J., Körschens, M., Graefe, J., 2006. A new approach to calculate the particle density of soils considering properties of the soil organic matter and the mineral matrix. Geoderma 130, 272-283. https://doi.org/10.1016/j.geoderma.2005.01.024

Rutgers, M., Schouten, A.J., Bloem, J., van Eekeren, N., De Goede, R.G.M., Jagers op Akkerhuis, G.A.J.M., van der Wal, A., Mulder, C., Brussaard, L., Breure, A.M., 2009. Biological measurements in a nationwide soil monitoring network. European Journal of Soil Science 60, 820-832. https://doi.org/10.1111/j.1365-2389.2009.01163.x

Rutgers, M., Van Wijnen, H.J., Schouten, A.J., Mulder, C., Kuiten, A.M.P., Brussaard, L., Breure, A.M., 2012. A method to assess ecosystem services developed from soil attributes with stakeholders and data of four arable farms. Science of The Total Environment 415, 39-48. https://doi.org/10.1016/j.scitotenv.2011.04.041

Saberian, M., Rahgozar, M.A., 2016. Geotechnical properties of peat soil stabilised with shredded waste tyre chips in combination with gypsum, lime or cement. Mires Peat 18, UNSP 16. https://doi.org/10.19189/MaP.2015.0MB.211

Salamon, J.-A., Alphei, J., Ruf, A., Schaefer, M., Scheu, S., Schneider, K., Sührig, A., Maraun, M., 2006. Transitory dynamic effects in the soil invertebrate community in a temperate deciduous forest: Effects of resource quality. Soil Biology and Biochemistry 38, 209-221. https://doi.org/10.1016/j.soilbio.2005.04.033

Säurich, A., Tiemeyer, B., Dettmann, U., Don, A., 2019. How do sand addition, soil moisture and nutrient status influence greenhouse gas fluxes from drained organic soils? Soil Biology and Biochemistry 135, 71-84. https://doi.org/10.1016/j.soilbio.2019.04.013 
Schekkerman, H., Beintema, A.J., 2007. Abundance of invertebrates and foraging success of Black-tailed Godwit Limosa limosa chicks in relation to agricultural grassland management. Ardea 95, 39-54. https://doi.org/10.5253/078.095.0105

Schothorst, C.J., 1982. Drainage and behaviour of peat soils. ICW, Wageningen.

Schothorst, C.J., 1977. Subsidence of low moor peat soils in the western Netherlands. Geoderma 17, $265-291$. https://doi.org/10.1016/0016-7061(77)90089-1

Schreefel, L., Schulte, R.P.O., de Boer, I.J.M., Schrijver, A.P., van Zanten, H.H.E., 2020. Regenerative agriculture - the soil is the base. Global Food Security 26, 100404. https://doi.org/10.1016/j.gfs.2020.100404

Schröder, J.J., ten Berge, H.F.M., Bampa, F., Creamer, R.E., Giraldez-Cervera, J.V., Henriksen, C.B., Olesen, J.E., Rutgers, M., Sandén, T., Spiegel, H., 2020. Multi-Functional Land Use Is Not Self-Evident for European Farmers: A Critical Review. Frontiers in Environmental Science 8, 575466. https://doi.org/10.3389/fenvs.2020.575466

Schwärzel, K., Renger, M., Sauerbrey, R., Wessolek, G., 2002. Soil physical characteristics of peat soils. Journal of Plant Nutrition and Soil Science 165, 479-486. https://doi.org/10.1002/15222624(200208)165:4<479::AID-JPLN479>3.0.CO;2-8

Senesi, N., Plaza, C., 2007. Role of humification processes in recycling organic wastes of various nature and sources as soil amendments. Clean - Soil, Air, Water 35, 26-41. https://doi.org/10.1002/clen.200600018

Shainberg, I., Sumner, M.E., Miller, W.P., Farina, M.P.W., Pavan, M.A., Fey, M.V., 1989. Use of gypsum on soils: a review, in: Stewart, B.A. (Ed.), Advances in Soil Science, Vol 9. Springer, New York, NY, pp. 1-111. https://doi.org/10.1007/978-1-4612-3532-3_1

Shannon, C., 1948. A mathematical theory of communication. Bell System Technical Journal 27, 379-423.

Shepherd, G., 2000. Visual soil assessment. Volume 1. Field guide for pastoral grazing and cropping on flat to rolling country. Regional Council \& Landcare Research, Palmerston North, New Zealand.

Shipley, B., 2016. Cause and Correlation in Biology: A User's Guide to Path Analysis, Structural Equations and Causal Inference with R. Cambridge University Press, Cambridge (UK).

Sieriebriennikov, B., Ferris, H., de Goede, R.G.M., 2014. NINJA: An automated calculation system for nematodebased biological monitoring. European Journal of Soil Biology 61, 90-93. https://doi.org/10.1016/j.ejsobi.2014.02.004

Sikkema, K., 1997. Manual for evaluation of grassland and ditch bank vegetation (in Dutch) (Themaboek No. 22). Praktijkonderzoek Rundvee, Schapen en Paarden, Lelystad, the Netherlands.

Sims, R.W., Gerard, B.M., 1985. Earthworms: Keys and Notes for the Identification and Study of the Species, Synopses of the British Fauna (New Series). The Linnean Society of London \& The Estuarine and Brackish-Water Sciences Association, London.

Smolders, A.J.P., Lamers, L.P.M., Lucassen, E.C.H.E.T., van der Velde, G., Roelofs, J.G.M., 2006. Internal eutrophication: How it works and what to do about it-a review. Chemistry and Ecology 22, 93-111. https://doi.org/10.1080/02757540600579730

Sognnes, L.S., Fystro, G., Øpstad, S.L., Arstein, A., Børresen, T., 2006. Effects of adding moraine soil or shell sand into peat soil on physical properties and grass yield in western Norway. Acta Agriculturae Scandinavica, Section B - Soil \& Plant Science 56, 161-170. https://doi.org/10.1080/09064710500218845

Song, Y., Song, C., Meng, H., Swarzenski, C.M., Wang, X., Tan, W., 2017. Nitrogen additions affect litter quality and soil biochemical properties in a peatland of Northeast China. Ecological Engineering 100, 175-185. https://doi.org/10.1016/j.ecoleng.2016.12.025

Sonneveld, M.P.W., Lantinga, E.A., 2011. The contribution of mineralization to grassland $\mathrm{N}$ uptake on peatland soils with anthropogenic A horizons. Plant and Soil 340, 357-368. https://doi.org/10.1007/s11104010-0608-7

Stone, D., Ritz, K., Griffiths, B.G., Orgiazzi, A., Creamer, R.E., 2016. Selection of biological indicators appropriate for European soil monitoring. Applied Soil Ecology 97, 12-22. https://doi.org/10.1016/j.apsoil.2015.08.005

Stöp-Bowitz, C., 1969. A contribution to our knowledge of the systematics and zoography of Norwegian earthworms (Annelida Oligochaeta: Lumbricidae). Nytt Magazin Zoologie 17, 169-280.

Strootman, B., Alkemade, F., Zandbelt, D., Van den Wittenboer, S., Francke, M., Groot, R., de Groot, K., van Paridon, R., Pijlman, J., Erisman, J.W., Timmerman, L., Spek, T., Burger, S., Gevaert, A., Waterloo, M., 
2020. On the way to a New Deal between farmer and society - Krimpenerwaard (in Dutch). College van Rijksadviseurs, Den Haag.

Struwe-Juhl, B., 1995. Auswirkungen der Renaturierungsmaßnahmen im Hohner See-Gebiet auf Bestand, Bruterfolg und Nahrungsökologie der Uferschnepfe (Limosa limosa). Corax 16, 153-172.

Sumner, M.E., Radcliffe, D.E., McCray, M., Carter, E., Clark, R.L., 1990. Gypsum as an ameliorant for subsoil hardpans. Soil Technology, Special Issue on Soil Compaction Control 3, 253-258.

https://doi.org/10.1016/0933-3630(90)90005-N

Swift, M.J., Izac, A.-M.N., van Noordwijk, M., 2004. Biodiversity and ecosystem services in agricultural landscapes-are we asking the right questions? Agriculture, Ecosystems \& Environment 104, 113-134. https://doi.org/10.1016/j.agee.2004.01.013

Thakur, M.P., Phillips, H.R.P., Brose, U., de Vries, F.T., Lavelle, P., Loreau, M., Mathieu, J., Mulder, C., van der Putten, W.H., Rillig, M.C., Wardle, D.A., Bach, E.M., Bartz, M.L.C., Bennett, J.M., Briones, M.J.I., Brown, G., Decaëns, T., Eisenhauer, N., Ferlian, O., Guerra, C.A., König-Ries, B., Orgiazzi, A., Ramirez, K.S., Russell, D.J., Rutgers, M., Wall, D.H., Cameron, E.K., 2020. Towards an integrative understanding of soil biodiversity. Biological Reviews 95, 350-364. https://doi.org/10.1111/brv.12567

Timmerman, A., Bos, D., Ouwehand, J., de Goede, R.G.M., 2006. Long-term effects of fertilisation regime on earthworm abundance in a semi-natural grassland area. Pedobiologia 50, 427-432. https://doi.org/10.1016/j.pedobi.2006.08.005

Tiunov, A.V., Scheu, S., 2004. Carbon availability controls the growth of detritivores (Lumbricidae) and their effect on nitrogen mineralization. Oecologia 138, 83-90. https://doi.org/10.1007/s00442-003-1391-4

Van Agtmaal, M., Deru, J., Pijlman, J., van Uffelen, R., Lenssinck, F., 2020. Peat enrichment with clay to reduce soil subsidence and CO2 emission in peat meadows (in Dutch). Bodem 2, 18-20.

Van Beek, C., 2007. Nutrient losses from grassland on peat soil (PhD thesis). Wageningen University, Wageningen.

Van Beek, C.L., Hummelink, E.W.J., Velthof, G.L., Oenema, O., 2004a. Denitrification rates in relation to groundwater level in a peat soil under grassland. Biology and Fertility of Soils 39, 329-336. https://doi.org/10.1007/s00374-003-0685-3

Van Beek, C.L., van den Eertwegh, G.A.P.H., van Schaik, F.H., Velthof, G.L., Oenema, O., 2004b. The contribution of dairy farming on peat soil to $\mathrm{N}$ and $\mathrm{P}$ loading of surface water. Nutrient Cycling in Agroecosystems 70, 85-95. https://doi.org/10.1023/B:FRES.0000045984.93498.c3

Van de Riet, B.P., Hefting, M.M., Verhoeven, J.T.A., 2013. Rewetting Drained Peat Meadows: Risks and Benefits in Terms of Nutrient Release and Greenhouse Gas Exchange. Water, Air \& Soil Pollution 224, 1440. https://doi.org/10.1007/s11270-013-1440-5

Van de Ven, G.P., 1993. Man-made lowlands: history of water management and land reclamation in the Netherlands. Uitgeverij Matrijs, Utrecht.

Van den Akker, J.J.H., Kuikman, P.J., de Vries, F., Hoving, I.E., Pleijter, M., Hendriks, R.F.A., Wolleswinkel, R.J., Simões, R.T.L., Kwakernaak, C., 2008. Emission of CO2 from agricultural peat soils in the Netherlands and ways to limit this emission, in: Farrell, C., Feehan, J. (Eds.), Proceedings of the 13th International Peat Congress After Wise Use - The Future of Peatlands. International Peat Society, Jyväskylä, Finland, pp. 645-648.

Van den Born, G.J., Kragt, F., Henkens, D., Rijken, B.C., van Bemmel, B., van der Sluis, S.M., Polman, N., Bos, E.J., Kuhlman, T., Kwakernaak, C., van den Akker, J.J.H., Diogo, V., Koomen, E., de Lange, G., van Bakel, J., 2016. Subsiding soils, rising costs: possible measures against peat subsidence in rural and urban areas: a policy study (in Dutch). (Report 1064). Planbureau voor de Leefomgeving, Den Haag.

Van den Pol-van Dasselaar, A., van Beusichem, M.L., Oenema, O., 1999. Methane emissions from wet grasslands on peat soil in a nature preserve. Biogeochemistry 44, 205-220. https://doi.org/10.1023/A:1006061814731

Van der Maarel, E., 1979. Transformation of cover-abundance values in phytosociology and its effects on community similarity. Vegetatio 39, 97-114. https://doi.org/10.1007/BF00052021

Van der Meer, H., van Middelkoop, J., de Visser, W., 2004. The nitrogen supply of peat soils (in Dutch), in: Van Kekem, A.J. (Ed.), Veengronden en Stikstof Leverend Vermogen. Alterra, Wageningen, pp. 33-50.

Van der Wal, A., Geerts, R.H.E.M., Korevaar, H., Schouten, A.J., Jagers op Akkerhuis, G.A.J.M., Rutgers, M., Mulder, C., 2009. Dissimilar response of plant and soil biota communities to long-term nutrient 
addition in grasslands. Biology and Fertility of Soils 45, 663-667. https://doi.org/10.1007/s00374-0090371-1

Van Dijk, J., Didden, W.A.M., Kuenen, F., van Bodegom, P.M., Verhoef, H.A., Aerts, R., 2009. Can differences in soil community composition after peat meadow restoration lead to different decomposition and mineralization rates? Soil Biology and Biochemistry 41, 1717-1725. https://doi.org/10.1016/j.soilbio.2009.05.016

Van Dijk, J., Stroetenga, M., Bos, L., van Bodegom, P.M., Verhoef, H.A., Aerts, R., 2004. Restoring natural seepage conditions on former agricultural grasslands does not lead to reduction of organic matter decomposition and soil nutrient dynamics. Biogeochemistry 71, 317-337. https://doi.org/10.1007/s10533-004-0079-0

Van Dijk, J., Stroetenga, M., van Bodegom, P.M., Aerts, R., 2007. The contribution of rewetting to vegetation restoration of degraded peat meadows. Applied Vegetation Science 10, 315-324. https://doi.org/10.1111/j.1654-109X.2007.tb00430.x

Van Eekeren, N., de Boer, H., Bloem, J., Schouten, T., Rutgers, M., de Goede, R., Brussaard, L., 2009a. Soil biological quality of grassland fertilized with adjusted cattle manure slurries in comparison with organic and inorganic fertilizers. Biology and Fertility of Soils 45, 595-608. https://doi.org/10.1007/s00374-009-0370-2

Van Eekeren, N., De Boer, H., Hanegraaf, M., Bokhorst, J., Nierop, D., Bloem, J., Schouten, T., de Goede, R., Brussaard, L., 2010. Ecosystem services in grassland associated with biotic and abiotic soil parameters. Soil Biology and Biochemistry 42, 1491-1504. https://doi.org/10.1016/j.soilbio.2010.05.016

Van Eekeren, N., Murray, P.J., Smeding, F.W., 2007. Soil biota in grassland, its ecosystem services and the impact of management, in: De Vliegher, A., Carlier, L. (Eds.), Grassland Science in Europe - Permanent and Temporary Grassland: Plant, Environment and Economy. European Grassland Federation, Ghent, pp. 247-258.

Van Eekeren, N., van Liere, D., de Vries, F., Rutgers, M., de Goede, R., Brussaard, L., 2009b. A mixture of grass and clover combines the positive effects of both plant species on selected soil biota. Applied Soil Ecology 42, 254-263. https://doi.org/10.1016/j.apsoil.2009.04.006

Van Kekem, A.J., 2004. Peat soils and nitrogen supply (in Dutch) (Report 965). Alterra, Wageningen.

Van Vliet, P.C.J., van der Stelt, B., Rietberg, P.I., de Goede, R.G.M., 2007. Effects of organic matter content on earthworms and nitrogen mineralization in grassland soils. European Journal of Soil Biology 43, S222S229. https://doi.org/10.1016/j.ejsobi.2007.08.052

Vellinga, T.V., André, G., 1999. Sixty years of Dutch nitrogen fertiliser experiments, an overview of the effects of soil type, fertiliser input, management and of developments in time. Netherlands Journal of Agricultural Sciences 47, 215-241.

Velthof, G. I., Oenema, O., 1995. Nitrous oxide fluxes from grassland in the Netherlands: II. Effects of soil type, nitrogen fertilizer application and grazing. European Journal of Soil Science 46, 541-549. https://doi.org/10.1111/j.1365-2389.1995.tb01350.x

Verhoeven, J.T.A., Setter, T.L., 2010. Agricultural use of wetlands: opportunities and limitations. Annals of Botany 105, 155-163. https://doi.org/10.1093/aob/mcp172

Verhulst, J., Kleijn, D., Berendse, F., 2007. Direct and indirect effects of the most widely implemented Dutch agri-environment schemes on breeding waders. Journal of Applied Ecology 44, 70-80.

Vestberg, M., Palojärvi, A., Pitkänen, T., Kaipainen, S., Puolakka, E., Keskitalo, M., 2012. Neutral lipid fatty acid analysis is a sensitive marker for quantitative estimation of arbuscular mycorrhizal fungi in agricultural soil with crops of different mycotrophy. Agricultural and Food Science 21, 12-27.

Vickery, J.A., Tallowin, J.R., Feber, R.E., Asteraki, E.J., Atkinson, P.W., Fuller, R.J., Brown, V.K., 2001. The management of lowland neutral grasslands in Britain: Effects of agricultural practices on birds and their food resources. Journal of Applied Ecology 38, 647-664.

Vogelzang, T.A., Borgstein, M.A., van den Elzen, G.J.F., Geerling-Eiff, F.A., Schrijver, R.A.M., Woud, M., 2004. "Farming with high water": a study of the future prospects for farming on wet peatlands in the "Groene Hart" (in Dutch) (Report 3.04.10). LEI, Den Haag.

Wagg, C., Bender, S.F., Widmer, F., Van der Heijden, M.G.A., 2014. Soil biodiversity and soil community composition determine ecosystem multifunctionality. Proceedings of the National Academy of Sciences 111, 5266-5270. https://doi.org/10.1073/pnas.1320054111 
Wall, D.H., Bardgett, R.D., Behan-Pelletier, V., Herrick, J.E., Jones, T.H., Ritz, K., Six, J., Strong, D.R., van der Putten, W.H., 2012. Soil Ecology and Ecosystem Services. Oxford University Press, Oxford.

Wang, W.J., Dalal, R.C., Moody, P.W., Smith, C.J., 2003. Relationships of soil respiration to microbial biomass, substrate availability and clay content. Soil Biology and Biochemistry 35, 273-284. https://doi.org/10.1016/S0038-0717(02)00274-2

Wardle, D.A., 2006. The influence of biotic interactions on soil biodiversity. Ecology Letters 9, 870-886. https://doi.org/10.1111/j.1461-0248.2006.00931.x

Wardle, D.A., 2002. Communities and Ecosystems: Linking the Aboveground and Belowground Components, Monographs in population biology. Princeton University Press, Princeton and Oxford.

Wasilewska, L., 2006. Changes in the structure of the soil nematode community over long-term secondary grassland succession in drained fen peat. Applied Soil Ecology 32, 165-179. https://doi.org/10.1016/j.apsoil.2005.07.003

Westhoff, V., van der Maarel, E., 1978. The Braun-Blanquet Approach, in: Whittaker, R.H. (Ed.), Classification of Plant Communities. Springer, Dordrecht, pp. 287-399.

Whalen, J.K., Chang, C., 2001. Phosphorus accumulation in cultivated soils from long-term annual applications of cattle feedlot manure. Journal of Environmental Quality 30, 229-237. https://doi.org/10.2134/jeq2001.301229x

Whittaker, R.H., 1960. Vegetation of the Siskiyou Mountains, Oregon and California. Ecological Monographs 30, 279-338. https://doi.org/10.2307/1943563

Wiggers, J.M.R., van Ruijven, J., Schaffers, A.P., Berendse, F., de Snoo, G.R., 2015. Food Availability for Meadow Bird Families in Grass Field Margins. Ardea 103, 17-26. https://doi.org/10.5253/arde.v103i1.a2

Yeates, G.W., 1987. How Plants Affect Nematodes, in: Macfadyen, A., Ford, E.D. (Eds.), Advances in Ecological Research. Academic Press, London, pp. 61-113.

You, S.-J., Yin, Y., Allen, H.E., 1999. Partitioning of organic matter in soils: effects of pH and water/soil ratio. Science of The Total Environment 227, 155-160. https://doi.org/10.1016/S0048-9697(99)00024-8 


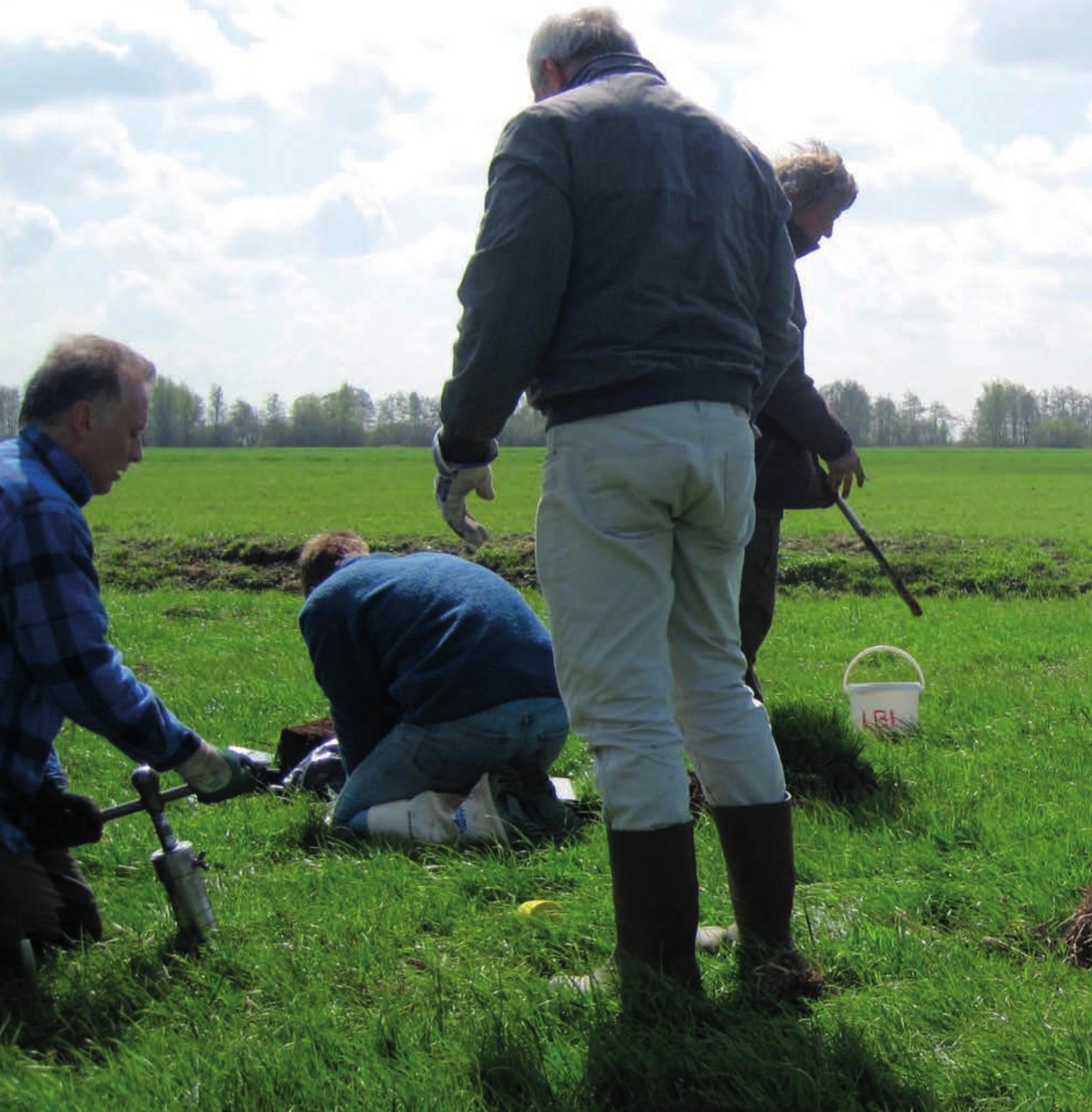


Samenvatting Dankwoord About the author List of publications Education statement Funding 



\section{Samenvatting}

Ontwaterde veengronden beslaan wereldwijd slechts $0.3 \%$ van het landoppervlak terwijl dat areaal voor $6 \%$ van de door mensen veroorzaakte $\mathrm{CO}_{2}$ emissie zorgt, als gevolg van de afbraak van organische stof door die ontwatering. Door klimaatverandering groeit de druk vanuit overheden om de $\mathrm{CO}_{2}$ emissie van deze veengebieden te verminderen. In Nederland vraagt de maatschappij van boeren en andere landgebruikers op veen dan ook steeds meer dat de veenafbraak verminderd wordt. Daarnaast wordt ook verwacht dat biodiversiteit, zoals weidevogels, beschermd en ondersteund wordt, dat bodems hun bufferfunctie vervullen bij droogte of hevige regenval, en dat nutriëntenverliezen naar het milieu sterk worden beperkt. Behalve voedselproductie wordt steeds meer verwacht dat landbouw ondersteunende en regulerende ecosysteemdiensten levert. Deze combinatie van opgaven vraagt om een integrale aanpak bij de beoordeling en afweging van mogelijke management-maatregelen voor veenweidegebieden.

Het overkoepelende doel van dit proefschrift is om inzicht te krijgen in de bodemkwaliteit van veengraslanden in relatie tot de ecosysteemdiensten (1) ondersteuning van biodiversiteit, (2) klimaatregulatie, (3) waterregulatie en (3) grasproductie, en om effecten van landgebruik en -beheer op deze ecosysteemdiensten vanuit dit integrale perspectief te beoordelen. Om dit te bereiken heb ik bodem- en vegetatiemetingen uitgevoerd in proeven in landbouw- en natuurgraslanden in het westelijk veenweidegebied.

Effecten van verschillend landgebruik op de levering van ecosysteemdiensten door veenweiden zijn beoordeeld in twintig landbouw- en twintig natuurgraslanden; deze verschilden in waterpeil en in intensiteit van begrazing, maaibeheer en bemesting. Hoofdstuk 2 presenteert botanische parameters en een uitgebreide set van biotische en abiotische bodemparameters van de bovengrond van deze graslanden. De landbouwgraslanden hadden een drogere, nutriëntrijkere en meer productieve bodem, een talrijker bodemleven en een hogere waterinfiltratiecapaciteit dan de natuurgraslanden. De natuurgraslanden hadden een lagere botanische en bodem $\alpha$-diversiteit (het gemiddelde aantal soorten per grasland), maar een hogere $\boldsymbol{y}$-diversiteit (het totaal aantal soorten gevonden in alle graslanden (per type) bij elkaar). Deze observatie werd verklaard door verschillen tussen beide soorten landgebruik in de beschikbaarheid van nutriënten, energie en vocht, en in ruimtelijke heterogeniteit. De potentiële C-mineralisatiesnelheid was gelijk in landbouw- en natuurgraslanden, maar de Cmineralisatie in de landbouwgraslanden was bacterie-gebaseerd en beperkt door droogte, terwijl de C-mineralisatie in de natuurgraslanden meer schimmel-gebaseerd was. Ik sluit dit 
hoofdstuk af met adviezen voor beheer van landbouw- en natuurgraslanden in relatie tot de ecosysteemdiensten (ondersteuning van) biodiversiteit, klimaatregulatie, waterregulatie en grasproductie.

In Hoofdstuk 3 leg ik de nadruk op de ecosysteemdienst grasproductie in relatie tot $\mathrm{N}$ mineralisatie in de bodem. Als gevolg van de grote variatie in $\mathrm{N}$ opbrengst van onbemest grasland (als maat voor het $\mathrm{N}$-leverend vermogen van de bodem) tussen verschillende landbouwgraslanden op veen kan het huidige bemestingsadvies, dat gebaseerd is op een vaste waarde voor het $\mathrm{N}$-leverend vermogen, tot onnodig hoge $\mathrm{N}$-verliezen leiden. Het doel van dit hoofdstuk is om een betere voorspelling te ontwikkelen voor het $\mathrm{N}$-leverend vermogen van de bodem en daarmee verliezen te helpen beperken. Ik gebruikte gegevens van Hoofdstuk 2 , vulde deze aan met drie verschillende schattingen van de $\mathrm{N}$-mineralisatie in de bodem tijdens het groeiseizoen (1: bodemincubaties in het laboratorium; 2: productie-ecologische berekeningen; 3: een combinatie van beide; alle gebaseerd op ecologische data), en correleerde deze met de grasopbrengsten die gemeten waren in dezelfde landbouwgraslanden tijdens dat jaar. Er is geen overeenkomst gevonden tussen de variatie in $\mathrm{N}$-leverend vermogen van de bodem en de variatie in geschatte $\mathrm{N}$-mineralisatie. Wel waren de bodemparameters $\mathrm{Ca}: \mathrm{Mg}$-verhouding en C:organische stof (C:OS)-verhouding statistisch de beste voorspellers voor respectievelijk het $\mathrm{N}$-leverend vermogen van de bodem en de bemeste grasopbrengst. De Ca:Mg-verhouding en C:OS-verhouding waren gerelateerd aan bodemstructuur en vochtbeschikbaarheid. Ik concludeer dat een deel van de ruimtelijke variatie in grasopbrengst kon worden voorspeld met indicatoren van bodemfysische en bodemhydrologische eigenschappen, die geen direct verband hadden met de $\mathrm{N}$-mineralisatie.

Op basis van de resultaten van Hoofdstuk 3 formuleerde ik de hypothese dat het verhogen van de Ca:Mg-verhouding in de bodem een positief effect op de grasgroei zou kunnen hebben door verbetering van de bodemstructuur of waterbeschikbaarheid, wat zou kunnen leiden tot lagere $\mathrm{N}$-verliezen. In Hoofdstuk 4 laat ik resultaten zien van een factoriële proef op drie veengraslanden die bij aanvang verschilden in $\mathrm{Ca:Mg-verhouding.} \mathrm{Hierin} \mathrm{werd}$ de $\mathrm{Ca}: \mathrm{Mg}$-verhouding veranderd door twee mineralen mét invloed op de $\mathrm{pH}$ (kalk: $\mathrm{CaCO}_{3}$ en magnesiet: $\mathrm{MgCO}_{3}$ ) en twee zónder invloed op de $\mathrm{pH}$ (gips: $\mathrm{CaSO}_{4}$ en kieseriet: $\mathrm{MgSO}_{4}$ ) toe te voegen. Binnen de twee jaar van de proef was de $\mathrm{N}$-opbrengst van onbemest gras voornamelijk in het eerste jaar beïnvloed door veranderingen in bodem $\mathrm{pH}$ en mineralisatie van organische stof, en niet door de $\mathrm{Ca}$ :Mg-verhouding. De toevoeging van $\mathrm{CaCO}_{3}$ verhoogde de $\mathrm{pH}$ en verlaagde $\mathrm{N}$ - en $\mathrm{C}$-totaal in de bodem, wat een aanduiding was voor aanzienlijke bodemmineralisatie van $\mathrm{N}$ en $\mathrm{C}$. Op basis van de verschillende behandelingseffecten op $\mathrm{pH}$, bodemorganische stof en labiele C-fractie HWC (de met heet water extraheerbare C) leidde ik 
af dat de $\mathrm{pH}$-gerelateerde afbraak van organische stof ook afhangt van de P-beschikbaarheid en Ca-binding. Daarom concludeer ik dat aanpassing van de $\mathrm{Ca}: \mathrm{Mg}$-verhouding in de bodem op zichzelf geen invloed heeft op de gras $\mathrm{N}$-opname, in ieder geval niet in de eerste twee jaar na toediening van de mineralen. Daarnaast zou verlies van bodem- $\mathrm{C}$ en $-\mathrm{N}$ vermeden kunnen worden door het huidige $\mathrm{pH}$-advies voor landbouwgraslanden op veen aan te passen aan de lokale bodemeigenschappen.

In een andere veldproef werd de toediening van organische en anorganische mestsoorten na drie opeenvolgende toedieningsjaren beoordeeld als een maatregel om ecosysteemdiensten van veenweiden te combineren, met het accent op ondersteunen van biodiversiteit (Hoofdstuk 5). Mestsoorten werden toegediend met een vaste hoeveelheid $\mathrm{N}$ (120 kg per hectare per jaar). De mestsoort-specifieke verschillen in C:N-verhouding resulteerden in verschillende hoeveelheden toegediende $\mathrm{C}$-totaal. Ik vond een verhoogd aantal strooiselbewonende (epigeïsche) regenwormen in de plots waar de vaste fractie van mechanisch gescheiden drijfmest was toegediend; dit was de mestsoort met de hoogste C:Nverhouding en grootste input van organische stof. Een gelijksoortig effect was waargenomen in plots waar zaagsel was gecombineerd met $\mathrm{N}$-kunstmest. Ten opzichte van mestsoorten met lagere C:N-verhoudingen bevorderden deze behandelingen ook de hoeveelheid arbusculaire mycorrhiza-schimmels. Dit verklaarde mogelijk het ontbreken van negatieve effecten van hoge $\mathrm{C}$-toevoegingen op de grasopbrengsten door $\mathrm{N}$-immobilisatie. Ik concludeer dat het gebruik van organische mestsoorten met een hoog gehalte aan niet-gehumificeerde organische stof een onderdeel kan zijn van een strategie om de levering van ecosysteemdiensten van veenweidgraslanden te optimaliseren.

Dit proefschrift biedt een integraal inzicht in de levering van ecosysteemdiensten in veenweidegraslanden en verkent wegen voor een duurzaam gebruik en beheer van veenbodems in lijn met vereisten vanuit de maatschappij. In Hoofdstuk 6 worden de resultaten van de vorige hoofdstukken in hun samenhang besproken vanuit het perspectief van de ecosysteemdiensten ondersteuning van biodiversiteit, klimaatregulatie, waterregulatie en grasproductie. Ik concludeer dat de biotische en abiotische kwaliteit van de bodem de basis vormt voor essentiële ecosysteemdiensten die veenweidegraslanden leveren, en dat het beheer van deze ecosysteemdiensten onlosmakelijk is gekoppeld aan de dynamiek van de bodemorganische stof en aan bodemhydrologie. Om de uitdagingen van de landbouw op veengrond de komende decennia beter het hoofd te bieden zal een vruchtbare samenwerking van melkveehouders met natuurbeheerorganisaties en de maatschappij als geheel nodig zijn. 


\section{Dankwoord}

Promoveren naast projectwerk en een (op-)groeiend gezin is een hele uitdaging! Mijn drijfveer was aanvankelijk vooral het plezier dat ik beleef aan inhoudelijke verdieping, maar gaandeweg ben ik gaan inzien hoeveel meerwaarde die verdieping kan hebben naast de reguliere projectrapportage, juist ook voor de praktijk. Ik hoop dan ook dat de bevindingen van dit proefschrift boeren, natuurbeheerorganisaties, beleidsmakers en collega-onderzoekers zal inspireren.

Voor dit eindresultaat waren veel proeven en heel veel meetgegevens nodig, maar ook veel tijd, energie, doorzettingsvermogen en bovenal een goede samenwerking met heel wat mensen. Dit dankwoord is gericht aan iedereen die dit mogelijk heeft gemaakt: degenen die aan de wieg stonden van het onderzoeksproject dat de wetenschappelijke basis was voor dit proefschrift, degenen die hebben geholpen bij de uitvoering, analyses, rapportages en andere noodzakelijke stappen, of die mij ruimte gaven om aan het proefschrift te werken. En natuurlijk degenen die mij hebben begeleid in dit leertraject.

Allereerst: Nick, jij was zelf bezig met de afronding van je PhD toen ik tijdens mijn sollicitatie bij het Louis Bolk Instituut aangaf graag te willen promoveren. Jij zag mogelijkheden binnen het project Bodemindicatoren voor duurzaam bodemgebruik in de veenweiden dat juist zou starten in een samenwerking met het CLM en het VIC. Na je promotie werd jij een van mijn co-promotoren. Zonder je gedrevenheid, je vermogen om steeds mogelijkheden te zien en je steun op cruciale momenten, zowel in het werk als privé, zouden dit project en dit resultaat er niet zijn geweest. Ik ben je erg dankbaar voor je begeleiding en onze samenwerking in dit promotietraject.

Lijbert, ook zonder jou als promotor was promoveren niet mogelijk geweest. Na mijn officiële inschrijving als externe PhD-student in 2013 hebben mijn projectwerk op het Louis Bolk Instituut, en ook thuis de gezinsuitbreiding, de aanvankelijke planning flink uitgerekt. Ik heb altijd jouw begrip hiervoor gevoeld, maar er was een duidelijke deadline en dan blijkt dat promoveren ook in de drukste omstandigheden mogelijk is! Nu heb ik de eer de rij te sluiten van alle mensen die bij jou zijn gepromoveerd. Ik wil je hartelijk danken voor je deskundige begeleiding, je scherpe en kritische blik en de manier waarop je steeds meedacht wanneer dat nodig was.

Ron en Jaap, jullie vulden mijn begeleidingsteam aan met jullie deskundigheid en betrokkenheid. Dank daarvoor! Ron, je precieze en kritische opmerkingen dwongen me 
steeds om verder te denken. Jaap, jij was ook betrokken bij de uitvoering van de projecten zelf, en ik kon op je rekenen voor inhoudelijke vragen of wanneer ik een nuchtere kijk op dilemma's nodig had.

Ik wil hier ook alle mensen bedanken die zich hebben ingespannen voor het project (fases 1 en 2) en/of meegeschreven en meegedacht hebben aan de artikelen: Frank Lenssinck, Wim Dijkman, Henk Kloen, Jan van den Akker, Ton Schouten, Michiel Rutgers, Harm Keidel, Gerard Jagers op Akkerhuis, Dré Nierop, Jan Bokhorst, Marleen Zanen, Nyncke Hoekstra, Maaike van Agtmaal, Bart Vromans, Sjoerd Smits en Christien Ettema. De financiering en begeleiding van het project was niet mogelijk geweest zonder de volhardende inzet van Eugène Thijssen, maar ook van Simon Moolenaar, Dirk van der Eijk, Frank Dorel, Jos Geenen, Coen Verstand, Esther de Winter, Frans van de Lindeloof, Gerard Agterberg, Willem Koops, Michelle Talsma, Douwe Jonkers, Niek de Wit, Theo de Boer, Erik Janssen en Hans van Vugt.

Een heel team van mensen heeft onmisbaar veld- en labwerk verricht. Mijn dank gaat uit naar Karel van Houwelingen, Mike Kroes, Riekje Bruinenberg, Hans Dullaert, Coen ter Berg, René Groenen, Hannah te Velde, Carmen Versteeg, Manon Kuyper, Evertjan Dijk, Gerben Bakker, Jaap Bogte, Popko Bolhuis, Henri den Hollander, Wim Dimmers, Tamás Salánki, Erik Steenbergen, Eef Velthorst, Meint Veninga†, An Vos, Jan Bovenschen en Arrienne Matser. Daarnaast hebben Arjan Reijneveld, Natasja Poot en Gerard Abbink aanvullende analyses geregeld. Ook waren achter de schermen twee mensen onmisbaar: Anna Koornneef bij het VIC en Marnella van der Tol bij de leerstoelgroep Bodembiologie.

De veehouders bij wie de proeven zijn uitgevoerd wil ik danken voor het beschikbaar stellen van hun percelen: familie Bakker, familie Beentjes, Egbert de Graaff, Bert de Groot, Marinus de Vries, Anton de Wit, Jan Graveland, Arno en Jacco Kastelein, Maarten Kea, Richard Korrel, Arno Plomp, Jaap Schep, Melvin Stolwijk $\dagger$, Herman en Mieke Vergeer, en het team van KTC Zegveld. Dat we in natuurgraslanden konden meten was mogelijk door de goede samenwerking met Zuid-Hollands Landschap, Natuurmonumenten en Staatsbosbeheer.

Er zijn ook nog-niet-genoemde (ex-)Bolk-collega's die op een of andere manier hebben bijgedragen aan dit werk door in meer of mindere mate mee te denken, tegen te lezen, de layout te helpen verzorgen of uren te regelen om het proefschrift af te ronden: Goaitske lepema, Jeroen Pijlman, Jan de Wit, Jan Paul Wagenaar, Edith Lammerts van Bueren, Merijn Bos, Martine Bruinenberg, Metha van Bruggen, Katinka van der Steen en de directie 
van het Louis Bolk Instituut. Mijn speciale dank gaat naar Pieter Struyk, Joost Sleiderink en Maaike van Agtmaal voor het overnemen van projectwerk op het cruciale moment van het schrijven van de algemene discussie; Maaike daarnaast ook voor je fijne manier van meedenken tijdens het schrijfproces, dit heeft me steeds geholpen om verder te komen. Goaitske, het was heel prettig om met jou als mede-PhD-student op allerlei vlakken ervaringen te kunnen delen en bespreken.

Gerard Oomen, jou wil ik ook bedanken. Je bijdrage is indirect, maar zeker van belang. Als docent en later ook mede-begeleider bij mijn afstudeervak in Wageningen heb jij mijn enthousiasme gevoed voor onderzoek dat is ingebed in een praktisch ideaal voor de (biologische) landbouwpraktijk. Ook zag jij een onderzoeker in mij en dat heeft mij later steeds gesteund in mijn wil om op basis van mijn werk bij het Louis Bolk Instituut een verdere wetenschappelijke stap te maken.

Dan wil ik alle vrienden, ouders van school en familieleden bedanken bij wie onze jongste twee kinderen wat vaker kwamen spelen, of die op een andere manier hebben geholpen, zodat ik mij kon concentreren op de afronding van mijn proefschrift! Met name wil ik hiervoor mijn schoonouders en Florence bedanken.

$\mathrm{Nu}$ is het tijd om de laatste woorden te richten aan Eva en onze vier mooie kinderen: Robinia, Einar, Sven Eirik en Joeri. Gelukkig was dit hele project verspreid over een flink aantal jaren, zodat ik naast onderzoeker en promovendus ook veel met jullie kon zijn. Nog mooier is het nu dat deze periode is afgesloten en dat er meer ruimte is voor avontuur met elkaar. Dank voor jullie steun en levensvreugde! 


\section{About the author}

Joachim Deru was born in 1977 in Assesse, Belgium, grew up in France and went to the secondary school in Maastricht, the Netherlands. Inspired by farmers who perceived agriculture as being part of the total ecosystem, Joachim studied Crop Sciences at Wageningen University (start in 1997), including a one year European curriculum Ecological Agriculture at the universities of Copenhagen (KVL), Wales (Aberystwyth) and Kassel (Witzenhausen). He interrupted his university study for a practical organic farming education (Sogn Jord- og Hagebruksskule) in Aurland, Norway (2001-2002). In Wageningen he specialized in Crop Ecology and Biological Farming Systems and graduated cum laude in 2004. After his studies, Joachim spent five years as an associate in a small company for organic products and combined this with project work for the Louis Bolk Institute. From 2009 on, he works fulltime as a Researcher Sustainable Animal Production and Agrobiodiversity at the Louis Bolk Institute. He has initiated, led and executed numerous projects on soil quality, nutrient cycling and mechanization in grassland, maize and sorghum in the Netherlands in close collaboration with colleagues inside and outside the Institute. One of the first projects he worked on (Bodemindicatoren voor duurzaam bodemgebruik in de veenweiden, 2009-2015) provided the data for his PhD thesis. From 2013 to 2021, Joachim had an external PhD position at the Soil Biology Group of Wageningen University in parallel to his work at the Louis Bolk Institute. 


\section{List of publications}

\section{Scientific papers}

Deru, J., Schilder, H., van der Schoot, J.R., van Eekeren, N., 2014. Genetic differences in root mass of Lolium perenne varieties under field conditions. Euphytica 199, 223-232. https://doi.org/10.1007/s10681-014-1129-x

De Boer, H.C., Deru, J.G.C., Hoekstra, N.J., van Eekeren, N., 2016. Strategic timing of nitrogen fertilization to increase root biomass and nitrogen-use efficiency of Lolium perenne L. Plant and Soil 407, 81-90. https://doi.org/10.1007/s11104-016-2917-y

Deru, J.G.C., Bloem, J., de Goede, R., Keidel, H., Kloen, H., Rutgers, M., van den Akker, J., Brussaard, L., van Eekeren, N., 2018. Soil ecology and ecosystem services of dairy and semi-natural grasslands on peat. Applied Soil Ecology 125, 26-34. https://doi.org/10.1016/j.apsoil.2017.12.011

De Boer, H.C., Deru, J.G.C., van Eekeren, N., 2018. Sward lifting in compacted grassland: effects on soil structure, grass rooting and productivity. Soil and Tillage Research 184, 317-325. https://doi.org/10.1016/j.still.2018.07.013

Deru, J.G.C., Bloem, J., de Goede, R., Hoekstra, N., Keidel, H., Kloen, H., Nierop, A., Rutgers, M., Schouten, T., van den Akker, J., Brussaard, L., van Eekeren, N., 2019. Predicting soil N supply and yield parameters in peat grasslands. Applied Soil Ecology 134, 77-84. https://doi.org/10.1016/j.apsoil.2018.10.018

De Boer, H.C., Deru, J.G.C., van Eekeren, N., 2020. Sward lifting in compacted grassland: Contrasting effects on two different soils. Soil and Tillage Research 201, 104564. https://doi.org/10.1016/j.still.2019.104564

lepema, G., Deru, J.G.C., Bloem, J., Hoekstra, N., de Goede, R., Brussaard, L., van Eekeren, N., 2020. Productivity and topsoil quality of young and old permanent grassland: An on-farm comparison. Sustainability 12, 2600. https://doi.org/10.3390/su12072600

Deru, J.G.C., Hoekstra, N., van Agtmaal, M., Bloem, J., de Goede, R., Brussaard, L., van Eekeren, N. Effects of $\mathrm{Ca}: \mathrm{Mg}$ ratio and $\mathrm{pH}$ on soil chemical, physical and microbiological properties and grass $\mathrm{N}$ yield in drained peat soil. (Under revision for publication in New Zealand Journal of Agricultural Research).

Deru, J.G.C., Bloem, J., de Goede, R., Brussaard, L., van Eekeren, N. Effects of organic and inorganic fertilizers on soil properties related to the regeneration of ecosystem services in peat grasslands. (Submitted).

Joachim Deru is also (co-)author of conference papers, brochures and reports. For an actual list, see https://www.louisbolk.nl/over-ons/medewerkers/joachim-gc-deru 


\section{PE\&RC Training and Education Statement}

With the training and education activities listed below the PhD candidate has complied with the requirements set by the C.T. de Wit Graduate School for Production Ecology and Resource Conservation (PE\&RC) which comprises of a minimum total of 32 ECTS ( $=22$ weeks of activities)

\section{Review of literature (5.5 ECTS)}

Indicators for sustainable soil management in peat

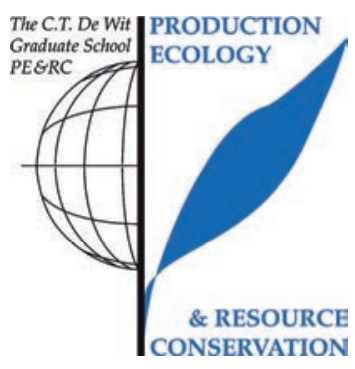
meadows of Zuid-Holland, Noord-Holland and Utrecht

\section{Writing of project proposal (3.5 ECTS)}

- Proposal for the experiments regarding management measures

\section{Post-graduate courses (3.5 ECTS)}

- Soil ecology; PE\&RC (2010)

- Root ecology; PE\&RC (2012)

\section{Laboratory training and working visits (1.2 ECTS)}

- Methodology of root measurement for grass and maize; Kiel University, Germany (2012)

- Grassland experiments on drought resistance, nutrient efficiency, interspecific competition; ILVO / Ghent University, Belgium (2012)

- Root research techniques; Jülich Research Centre, Germany (2016)

Deficiency, refresh, brush-up courses (1.8 ECTS)

- Linear models; PE\&RC (2013)

- Introduction to data science with R and R studio; PE\&RC (2021)

\section{Competence strengthening / skills courses (2.5 ECTS)}

- Presentation skills; Louis Bolk Institute (2009)

- Techniques for writing and presenting a scientific paper; PE\&RC (2014)

- Reviewing a scientific paper; PE\&RC (2016)

- Project management skills; Louis Bolk Institute (2016)

PE\&RC Annual meetings, seminars and the PE\&RC weekend (2.2 ECTS) PE\&RC Day, Wageningen (2014)

- Symposium Frontiers in ecology; PE\&RC, Wageningen (2017)

- Netherlands annual ecology meeting; Lunteren (2020)

Discussion groups / local seminars or scientific meetings (5.4 ECTS)

- Dutch soil quality monitoring network; Wageningen (2010)

- Discussion about results with CLM Onderzoek en Advies, Culemborg (2010-2012)

- Symposium Bodembreed; Lunteren (2011)

- Discussion group on decomposition; DECOlab Universiteit Utrecht, Utrecht (2011)

- Vegetation - soil interactions: from rhizosphere to ecosystem; Wageningen (2014)

- Earthworm ecology; Wageningen (2014)

- European Grassland Federation meeting; Aberystwyth, UK (2014)

- European Grassland Federation meeting; Trondheim, Norway (2016)

International symposia, workshops and conferences (7.9 ECTS)

- European grassland federation meeting; poster presentation; Lublin, Poland (2012)

- Rhizosphere 4; oral presentation; Maastricht, the Netherlands (2015)

- European grassland federation meeting; poster presentation; Wageningen, the Netherlands (2015)

- Wageningen soil conference; oral presentation; Wageningen, the Netherlands (2017) 


\section{Funding}

This work was part of the projects Bodemindicatoren voor duurzaam bodemgebruik in de veenweiden, Proeftuin Veenweiden and Winst en weidevogels. These projects were funded by Stichting Kennisontwikkeling en Kennisoverdracht Bodem; the Provinces NoordHolland, Zuid-Holland and Utrecht; Interdepartementaal Programma Biodiversiteit; the Dutch Ministry of Infrastructure and Water Management; the Dutch Ministry of Agriculture, Nature and Food Quality; ZuiveINL; LTO Noord Fondsen; WUR Environmental Research; STOWA.

The financial support from the Louis Bolk Institute for writing this thesis is greatly acknowledged.

Printing of this thesis has been made possible by the financial support from Wageningen University and Louis Bolk Institute.

Photographs: Marleen Zanen, Joachim Deru, Jan Bokhorst Cover and layout: Joachim Deru, Metha van Bruggen, ProefschriftMaken 



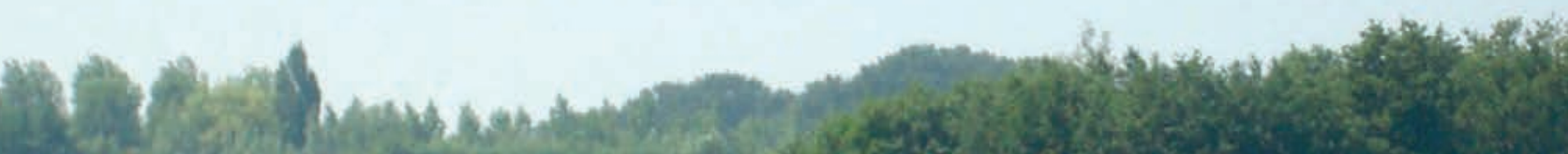

